\title{
'PROBLEMS AND PROSPECTS OF WOMEN ENTREPRENEURSHIP WITH SPECIAL REFERENCE TO MSMES IN THE STATE OF GUJARAT'
}

A Thesis Submitted to Gujarat Technological University

\author{
For the Award of \\ Doctor of Philosophy
}

In

Management

By

Ranjana Singh

129990992024

Under the Supervision of

Prof. S.O. Junare

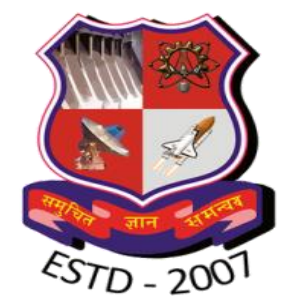

GUJARAT TECHNOLOGICAL UNIVERSITY, AHMEDABAD

[May, 2017] 


\section{'PROBLEMS AND PROSPECTS OF WOMEN ENTREPRENEURSHIP WITH SPECIAL REFERENCE TO MSMES IN THE STATE OF GUJARAT'}

A Thesis Submitted to Gujarat Technological University

For the Award of

Doctor of Philosophy

In

Management

by

Ranjana Singh

129990992024

Under the Supervision of

Prof. S.O. Junare

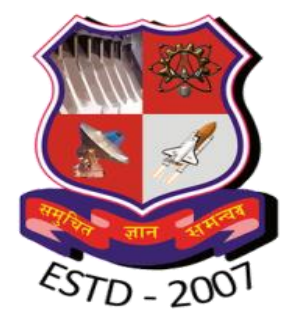

GUJARAT TECHNOLOGICAL UNIVERSITY, AHMEDABAD

[May, 2017] 
(C) [RANJANA SINGH] 


\section{DECLARATION}

I declare that the thesis entitled 'Problems and Prospects of Women Entrepreneurship With Special Reference to MSMEs in the State of Gujarat' submitted by me for the degree of Doctor of Philosophy is the record of research work carried out by me during the period from $19^{\text {th }}$ July, 2013 to $19^{\text {th }}$ May, 2017 under the supervision of Prof. S.O. Junare, Gujarat Forensic Sciences University, Gandhinagar and this has not formed the basis for the award of any degree, diploma, associateship, fellowship, titles in this or any other University or other institution of higher learning. I further declare that the material obtained from other sources has been duly acknowledged in the thesis. I shall be solely responsible for any plagiarism or other irregularities, if noticed in the thesis.

Signature of the Research Scholar:

Date: $19^{\text {th }}$ May, 2017

Name of Research Scholar: Ranjana Singh

Place: Gandhinagar 


\section{CERTIFICATE}

I certify that the work incorporated in the thesis Problems and Prospects of Women Entrepreneurship With Special Reference to MSMEs in the State of Gujarat' submitted by Ms. Ranjana Singh was carried out by the candidate under my supervision/guidance. To the best of my knowledge: (i) the candidate has not submitted the same research work to any other institution for any degree/diploma, Associateship, Fellowship or other similar titles (ii) the thes is submitted is a record of original research work done by the Research Scholar during the period of study under my supervision, and (iii) the thesis represents independent research work on the part of the Research Scholar.

Signature of Supervisor:

Date: $19^{\text {th }}$ May, 2017

Name of Supervisor: Prof. S.O. Junare, Gujarat Forensic Sciences University

Place: Gandhinagar 


\section{ORIGINALITY REPORT CERTIFICATE}

It is certified that $\mathrm{PhD}$ Thesis titled 'Problems and Prospects of Women Entre preneurship with Special Reference to MSMEs of the State of Gujarat' by Ms. Ranjana Singh has been examined by us. We undertake the following:

a) Thesis has significant new work / knowledge as compared already published or are under consideration to be published elsewhere. No sentence, equation, diagram, table, paragraph or section has been copied verbatim from previous work unless it is placed under quotation marks and duly referenced.

b) The work presented is original and own work of the author (i.e. there is no plagiarism). No ideas, processes, results or words of others have been presented as Author own work.

c) There is no fabrication of data or results which have been compiled / analyzed.

d) There is no falsification by manipulating research materials, equipment or processes, or changing or omitting data or results such that the research is not accurately represented in the research record.

e) The thesis has been checked using turnitin and found within limits as per GTU Plagiarism Policy and instructions issued from time to time (i.e. permitted similarity index $<=25 \%)$.

Signature of the Research Scholar:

Date: $19^{\text {th }}$ May, 2017

Name of Research Scholar: Ms. Ranjana Singh

Place: Gandhinagar

Signature of Supervisor:

Date: $19^{\text {th }}$ May, 2017

Name of Supervisor: Prof. S.O.Junare

Place: Gandhinagar 


\section{turniting}

\section{Digital Receipt}

This receipt acknowledges that Turnitin received your paper. Below you will find the receipt information regarding your submission.

The first page of your submissions is displayed below.

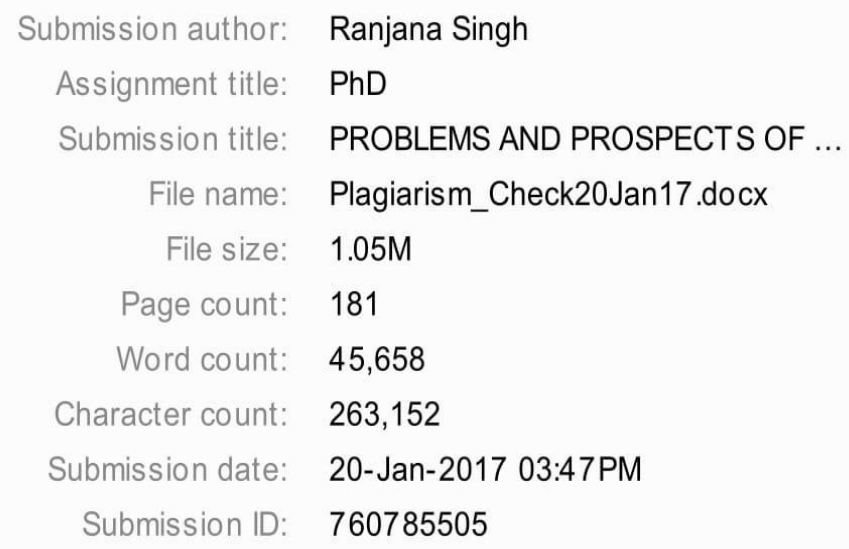




\section{PROBLEMS AND PROSPECTS OF WOMEN ENTREPRENEURSHIP WITH SPECIAL REFERENCE TO MSMES IN THE STATE OF GUJARAT}

ORIGINALITY REPORT

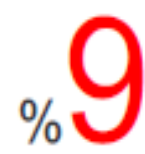

SIMILARTY Y INDEX

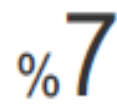

INTERNET SOURCES
$\% 3$

PUBLICATIONS
$\% 5$

STUDENT PAPERS

PRIMARY SOURCES

1 Submitted to Yeditepe University

Student Paper

$\% 3$

2 tabenoboru.com

3 Michael Fritsch. "The effect of new business formation on regional development over time: the case of Germany", Small Business

Economics, 11/26/2007

Publication

4 insis.vse.cz Internet Source

5 wol.iza.org

6 en.wikipedia.org

7 www.unescap.org 


\section{PhD THESIS Non-Exclusive License to GUJARAT TECHNOLOGICAL UNIVERSITY}

In consideration of being a PhD Research Scholar at GTU and in the interests of the facilitation of research at GTU and elsewhere, I, Ranjana Singh, having Enrollment No. $\mathbf{1 2 9 9 9 0 9 9 2 0 2 4}$ hereby grant a non-exclusive, royalty free and perpetual license to GTU on the following terms:

a) GTU is permitted to archive, reproduce and distribute my thesis, in whole or in part, and/or my abstract, in whole or in part ( referred to collectively as the "Work") anywhere in the world, for non-commercial purposes, in all forms of media;

b) GTU is permitted to authorize, sub-lease, sub-contract or procure any of the acts mentioned in paragraph (a);

c) GTU is authorized to submit the Work at any National / International Library, under the authority of their "Thesis Non-Exclusive License";

d) The Universal Copyright Notice (C) shall appear on all copies made under the authority of this license;

e) I undertake to submit my thesis, through my University, to any Library and Archives. Any abstract submitted with the thesis will be considered to form part of the thesis.

f) I represent that my thesis is my original work, does not infringe any rights of others, including privacy rights, and that I have the right to make the grant conferred by this non-exclusive license.

g) If third party copyrighted material was included in my thesis for which, under the terms of the Copyright Act, written permission from the copyright owners is required, I have obtained such permission from the copyright owners to do the acts mentioned in paragraph (a) above for the full term of copyright protection.

h) I retain copyright ownership and moral rights in my thesis, and may deal with the copyright in my thesis, in any way consistent with rights granted by me to my University in this non-exclusive license.

i) I further promise to inform any person to whom I may hereafter assign or license my copyright in my thesis of the rights granted by me to my University in this nonexclusive license. 
j) I am aware of and agree to accept the conditions and regulations of $\mathrm{PhD}$ including all policy matters related to authorship and plagiarism.

Signature of the Research Scholar:

Name of Research Scholar: Ms. Ranjana Singh

Date: $19^{\text {th }}$ May, 2017

Place: Ahmedabad

Signature of Supervisor:

Name of Supervisor: Prof. S.O. Junare,

Gujarat Forensic Sciences University

Date: $19^{\text {th }}$ May, 2017

Place: Ahmedabad

Seal: 


\section{Thesis Approval Form}

The viva-voce of the $\mathrm{PhD}$ Thesis submitted by Ms. Ranjana Singh (Enrollment No. 129990992024) entitled 'Problems and Prospects of Women Entrepreneurship with Special Reference to MSMEs in the State of Gujarat was conducted on $19^{\text {th }}$ May, 2017 at Gujarat Technological University.

\section{(Please tick any one of the following option)}

The performance of the candidate was satisfactory. We recommend that he/she be awarded the $\mathrm{PhD}$ degree.

Any further modifications in research work recommended by the panel after 3 months from the date of first viva-voce upon request of the Supervisor or request of Independent Research Scholar after which viva-voce can be re-conducted by the same panel again.

(Briefly specify the modifications suggested by the panel)

The performance of the candidate was unsatisfactory. We recommend that he/she should not be awarded the $\mathrm{PhD}$ degree.

(The panel must give justifications for rejecting the research work)

Name and Signature of Supervisor with Seal

2) External Examiner 2) Name \& Signature
1) External Examiner 1) Name \& Signature

3) External Examiner 3) Name \& Signature 


\begin{abstract}
Purpose

In Gujarat there exists a dire need to identify various enabling factors, limiting factors and prospective factors which limits/encourages women to pursue their entrepreneurial dreams. This paper aims to identify the above mentioned by interviewing women entrepreneurs of the state of Gujarat.

\section{Design/methodology/approach}

It is an exploratory research which has been conducted to study women entrepreneurs in the state of Gujarat. A total of 401 sample women entrepreneurs have been interviewed with help of interview schedule from Gandhinagar (North), Kachch (East), Rajkot (Saurashtra), Vadodara (West), Surat (South) and Ahmedabad (Central) to reach to a fair conclusion. Data has been analyzed by using IBM SPSS Statistics 21.0 version and Microsoft Windows 2007 Office Excel Worksheet has been used to present results in form of tables, bar charts and pie charts wherever applicable. For analysis, the significance level is 0.05. Using the sample data chi-square test of independence is conducted.
\end{abstract}

\title{
Findings
}

In case of women entrepreneurs in Gujarat education, family and inner zeal and will-power are vital enabling factors which elevate their motivation scale to perform in the state. Most hurdling limiting factors have been dual role in home and business, poor knowledge of government support schemes, ignorance about banking procedures and formalities, poor knowledge of financial management, lack of leisure time and lack of technological skills. With regard to prospect, researcher found that there exist ample prospects in services sector over manufacturing and other trading business.

\section{Research limitations/implications}

The research is based on the lands of Gujarat hence language barrier has been most important for the researcher. Besides language other barriers have been approach of those respondents who sought husband's permission to give responses to the researcher, government data as many registered units were mostly shut or women owner respondents showed their inability 
to respond to the researcher even on repeated approaches made by the researcher because of their personal engagements.

\section{Originality/value}

In the literature history of entrepreneurship especially in Gujarat, there is lack of state wide study conducted with special focus on women entrepreneurs. This study is one of its kinds of study which is going to form a basis for many future researches which seek to further study the status of problems and prospects of women entrepreneurs to successfully run and sustain in their entrepreneurial venture. As a suggestion 'Chief Facilitator Process' has been proposed to create empowered entrepreneurial culture to women entrepreneurs.

Key Word - Entrepreneurship, Women Entrepreneurship, MSMEs, Enabling factors, Limiting factors and Prospects 


\section{Acknowledgement}

At the outset I would like to express my humble gratitude to Prof. S.O. Junare for guiding me through the expedition of doctorate research. It was my honor to be associated with Prof. Junare, a man of tremendous knowledge and true values. I appreciate his contributions to my research be it in form of time, valuable research inputs, guidance for approaching the respondents, ideas for nurturing chapter writing skills are few to highlight. He allowed me to grow as a researcher and shaped and encouraged my ideas in a constructive sense. Your guidance on research or on choosing the career path has always been and will always be invaluable for me.

This research would not have been possible to complete without the inputs from my Doctoral Progress Committee Prof. Rajesh Khajuria, Director, C.K. Shah Vijapurwala Institute of Management, Vadodara and Dr. Tejas Shah, Associate Professor, Shanti Business School, Ahmedabad. I am immensely grateful for their feedback and guidance throughout my research.

I would like to extend my heartfelt gratitude to Dr. Kishore Bhanushali, Associate Professor Unitedworld School of Business (UWSB), my colleagues at Central University of Gujarat (CUG) especially Dr. Litty Denis, Dr. Sudeep Basu and Dr. Sony Kunjappan, former colleagues at Unitedworld School of Law, Gandhinagar (UWSL) and former colleagues at Gujarat National Law University (GNLU). This journey would have been incomplete without the unconditional support extended by them whenever needed.

I am deeply thankful to Ms. Mona Chaurasiya, Ms. Rajani Bhandari, support staff of PhD Section and Mr. Dhaval Gohil at GTU for their timely support to get through all the mandates effortlessly.

A special thanks to my friends Dr. M. Roja Lakshmi, Assistant Professor (CUG), Mr. Sarthak Jena, Research Scholar, IIT-Kharagpur, Ms. Urvi Shah, Assistant Professor, UWSL, Ms. Priyanka Dhargave, Assistant Professor (CUG), Mr. Nishant Kumar, Assistant Professor (CUG) and Dr. Vikas Trivedi, Assistant Professor, Institute of Law, Nirma University for their ceaseless encouragement and to help me develop ideas.

I would like to convey my deep sense of appreciation to Shri. Chandan Chaterjee, Director, Center for Entrepreneurship Development (CED), Shri. Dharmendra Joshi, Secretary, Gujarat Chamber of Commerce and Industries (GCCI) and his associates, Business Women's Wing- 
GCCI and most importantly all the participating respondents who shared their valuable inputs to add value to my work and to make this research a success.

I would like to convey special thanks to very special friend Mr. Aakash Nagpal and Ms. Tania Sebastian who has been instrumental in engendering in me the quest for research. According to Buddha "A family is a place where minds come in contact with one another". Going by this I asseverate this work to be an outcome of sincere hardships of my entire family. I am thankful to almighty to bestow upon me his blessings in form of my wonderful family. I appreciate their contribution and dedicate this work to my ever supporting family especially my mother (Smt. M.K. Devi) and father (Shri. A.P. Singh). At the end I express my earnest indebtedness to Mrs. Rekha Nagpal and family, little niece Dhanishta and Shriya for bearing with me and for all those uncountable moments when they stood by me and kept me going all through this endeavor.

\author{
Ranjana Singh \\ Research Scholar \\ Gujarat Technological University
}




\section{Table of content}

List of Abbreviations.............................................................

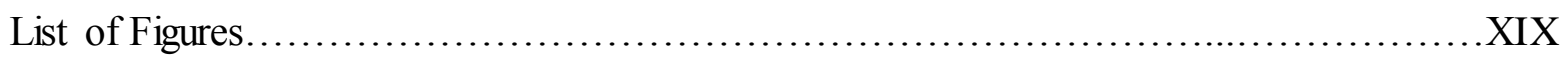

List of Tables.................................................................

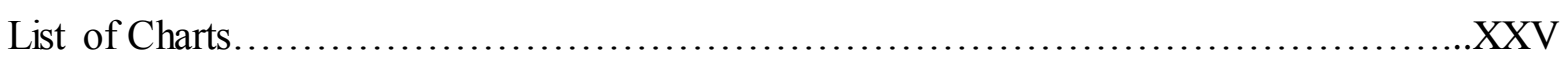

List of Appendices......................................................

Chapters - 1-Introduction to Entrepreneurship, MSMEs and Women Entrepreneurship....01

1.1. Introduction........................................................

1.2. Conceptual insights on the frequently used terminologies $\ldots \ldots \ldots \ldots \ldots \ldots \ldots \ldots . . . \ldots 5$

1.2.1. Entrepreneurship................................................... 05

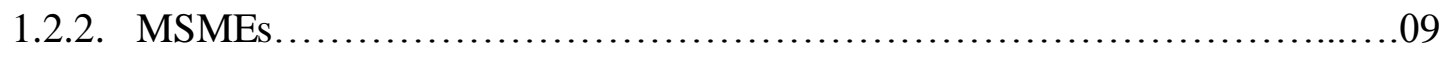

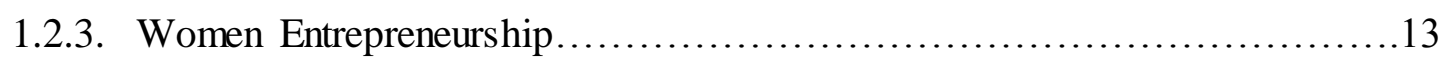

1.3. Theories of Entrepreneurship........................................... 15

1.3.1. Economic Theory of Entrepreneurship............................... 15

1.3.2. Sociological Theory of Entrepreneurship............................... 17

1.3.3. Psychological Theory of Entrepreneurship.............................18

1.4. Types of Entrepreneurs..................................................20

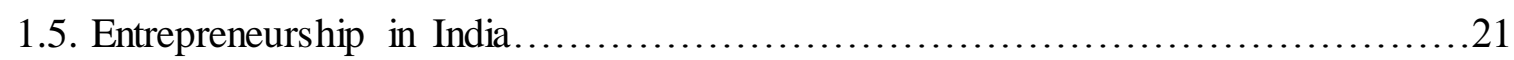

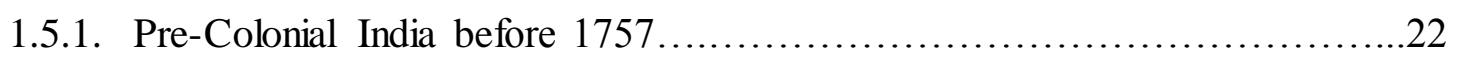

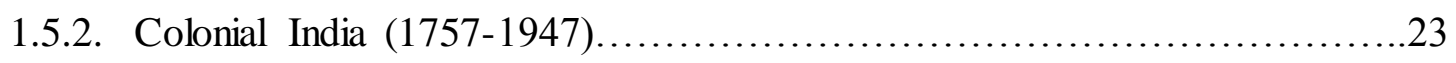

1.5.3. Post-independence (1947 onwards)................................25

1.5.4. Post 1991- Impact of Liberalization................................27

1.5.5. Post Recession (2008 onwards) .....................................30

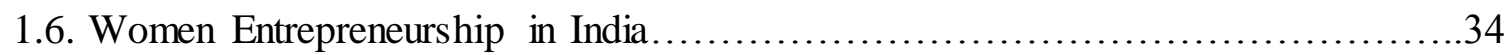

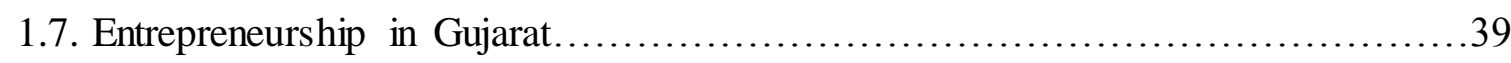

1.7.1. National Data Important for the Purpose of Study........................40

1.7.2. State Specific Data for the Purpose of the Study.........................41

1.8. National and State Specific Scheme for Women Entrepreneurs....................44

1.8.1. National Schemes.................................................44

1.8.2. State Schemes..................................................49

1.9. Statement of Problem and Research Questions................................51 


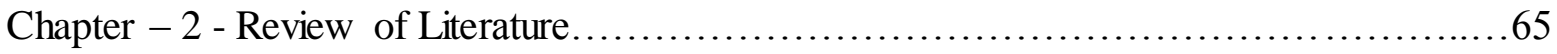

2.1. International Evidences.................................................65

2.2. National Evidences.................................................. 78

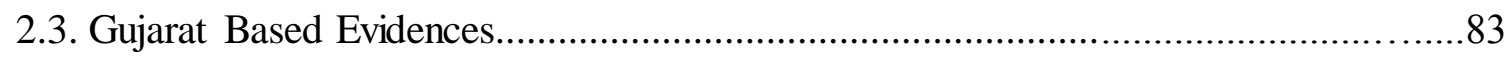

2.4. Research Gap...................................................... 88

Chapter - 3 - Research Design \& Research Methodology................................97

3.1. Objectives......................................................... 98

3.2. Hypothesis ........................................................ 98

3.3. Scope and Limitation of the Study........................................ 99

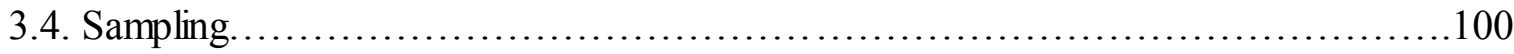

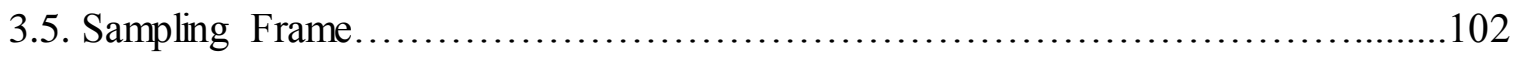

3.6. Data Collection........................................................... 103

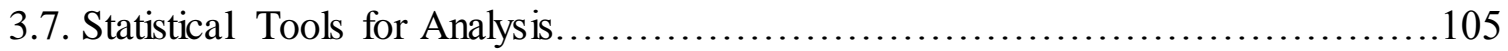

3.8. Scheme of Chapterization............................................... 106

Chapter - 4 - Data Analysis and Interpretation.................................... 108

4.1. Demographic Profile of Women Entrepreneurs ................................ 109

4.2. Starting a Business - Methods and Reasons................................122

4.3. Profile of Women Owned Businesses........................................ 126

4.4. Source of Continuous Support and Enabling Factors for Women Entrepreneurs....148

4.5. Problems faced by Women Entrepreneurs.................................... 153

4.6. Prospects for Women Entrepreneurs ........................................... 179

Chapter -5 - Findings, Suggestion and Conclusion................................ 188

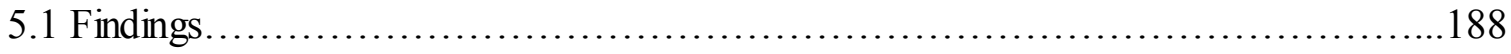

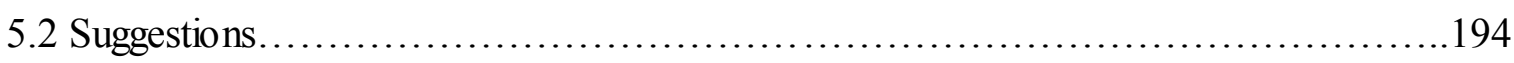

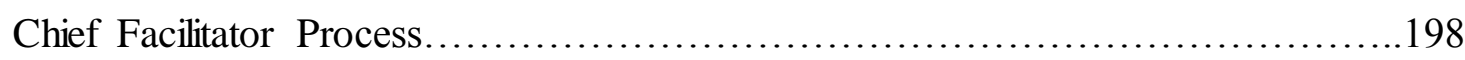

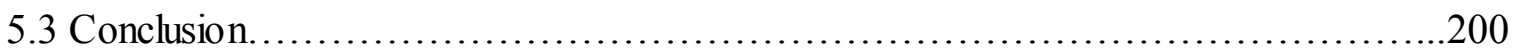

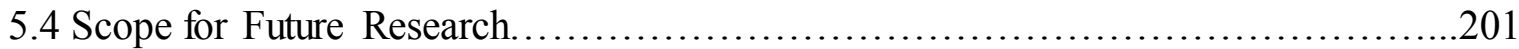

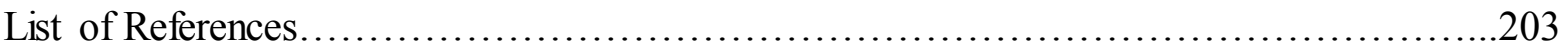




\section{List of important abbreviations}

GEM: Global Entrepreneurship Monitor

SC: Scheduled Caste

ST: Scheduled Tribes

TREAD: Trade Related Entrepreneurship Assistance and Development

MUDRA: Micro Units Development and Refinancing Agency Scheme

MSME: Micro, Small and Medium Enterprise

SSI: Small Scale Industries

OECD: Organization for Economic Co-operation and Development

GDP: Gross Domestic Product

EU: European Union

A.D: Anno Domini

EPW: Economic and Political Weekly

US: United States

UK: United Kingdom

SME: Small and Medium Enterprises

PM: Prime Minister

UNCTAD: United Nations Conference on Trade and Development

DOE: Department of Expenditure

CVC: Chief Vigilance Commission

ESIC: Employees' State Insurance Corporation

EPF: Employees Provident Fund

IID: Integrated Infrastructural Development

PPP: Public-Private Partnership

NMCP: National Manufacturing Competitiveness Programme 
CAPART: Council for the Advancement of Peoples Action and Rural Technology

CII: Confederation of Indian Industry

MENA: Middle East and North Africa

IFC: International Finance Corporation

GEDI: Gender Global Entrepreneurship and Development Index

ISED: Institute of Small Enterprises and Development

FICCI: Federation of Indian Chamber of Commerce \& Industry

GoI: Government of India

GoG: Government of Gujarat

NIESBUD: National Institute of Entrepreneurship and Small Business Development

EDI: Entrepreneurship Development Institute, India

CED: Center for Entrepreneurship Development, India

NI-MSME: National Institute for Micro, Small and Medium Enterprises

IIE: Indian Institute of Entrepreneurship

ATI: Assistance to Training Institutions

NSIC: National Small Industries Corporation

NGO: Non-governmental Organization

NER: North Eastern Region

MSE-CDP: Micro and Small Enterprises - Cluster Development Programme

KVIC: Khadi and Village Industries Commission

KVIB: Khadi and Village Industries Board

DIC: District Industries Centre

WM: Water Mills

MHP: Micro Hydel Projects

STEP: Support to training and Employment Programme

WCD: Women and Child Development Department

GWEDC: Gujarat Women's Economic Development Corporation 
CGTMSE: Credit Guarantee Fund Trust for Micro and Small Enterprises

GCCI: Gujarat Chambers of Commerce and Industries

GIDC: Gujarat Industrial Development Corporation

ICT: Information and Communications Technology

SWOT: Strength, Weakness, Opportunities and Threat

SSC: Secondary School Certificate

UP: Uttar Pradesh

UNICEF: United Nations Children's Fund

UNESCO: United Nations Educational, Scientific and Cultural Organization

NITIE: National Institute of Industrial Engineering

EDP: Entrepreneurship Development Programme

ICECD: International Centre for Entrepreneurship and Career Development

IIM-A: Indian Institute of Management - Ahmedabad

IDBI: Industrial Development Bank of India

UNESCAP: United Nations Economic and Social Commission for Asia and the Pacific

IT: Information Technology

CSR: Corporate Social Responsibility

BRICS: Brazil, Russia, India, China and South Africa

BWW-GCCI: Business Women's Wing, Gujarat Chamber of Commerce and Industries

FICCI-FLO: FICCI Ladies Organization

TiE: The Indus Entrepreneurs

SEWA: Self Employed Women's Association 


\section{List of figures}

FIG 1.1 MSME Densities across the World .................................... 10

FIG 1.2 Six Major Thematic Areas for MSMEs.................................. 32

FIG 1.3 Process of growth in Social Status of Women Entrepreneur.....................34

FIG 3.1 Selected cities for data collection....................................... 104

FIG 5.1 Problems faced by Women Entrepreneurs in the state of Gujarat..............193

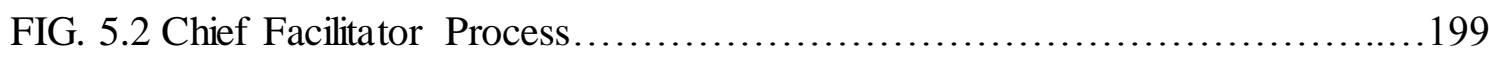




\section{List of table}

TABLE 1.1 The elements mentioned most frequently in definitions of the term 'Entrepreneur'.

TABLE 1.2 SME Shares of Manufactured Exports in Developing and OECD Economies.

TABLE 1.3 Definition of MSMEs as per MSME Act, 2006.........................12

TABLE 1.4 Economic Theories of Entrepreneurship............................16

TABLE 1.5 Sociological Theories of Entrepreneurship.......................... 17

TABLE 1.6 Psychological Theories of Entrepreneurship...........................19

TABLE 1.7 Typologies of Entrepreneurs......................................20

TABLE 1.8 Women Enterprises in MSME sector in the India........................35

TABLE 1.9 Ten leading States in terms of Number of Enterprises and their respective

Employment Generation...........................................40

TABLE 1.10 District Wise Report on Number of Working, Closed, Not Found Units...42

TABLE 1.11 District Wise Report on Number of Male and Female Owned MSMEs...43

TABLE 3.1 City wise data collection..................................... 102

TABLE 3.2 Organizations and Primary/Secondary Data Received.....................105

TABLE 4.1 Age distribution of Women Entrepreneurs.........................110

TABLE 4.2 Education level of Women Entrepreneurs............................111

TABLE 4.3 Marital Status of Women Entrepreneurs........................... 112

TABLE 4.4 Husband's Education.............................................. 113

TABLE 4.5 Husband's Occupation........................................ 114 
TABLE 4.6 Father's Education.

TABLE 4.7 Father's Occupation.......................................... 117

TABLE 4.8 Mother's Education............................................. 118

TABLE 4.9 Mother's Occupation.............................................. 119

TABLE 4.10 If anybody has prior business experience in family?..............................121

TABLE 4.11 Did Women Entrepreneur receive any help from those family members' who are already into business?..........................................................121

TABLE 4.12 Mode to start the business..........................................123

TABLE 4.13 Reason to start business....................................... 124

TABLE 4.14 Year of establishment.............................................. 125

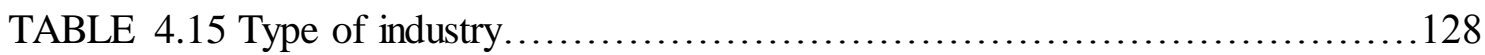

TABLE 4.16 Type of manufacturing activity................................. 130

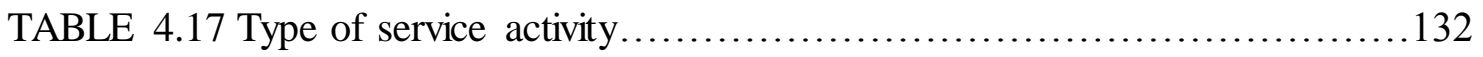

TABLE 4.18 Size of business.................................................. 134

TABLE 4.19 Table to represent the relationship between age of women entrepreneurs and size of their businesses.....................................135

TABLE 4.20 Table to represent the relationship between education level of women entrepreneurs and size of their businesses.........................136

TABLE 4.21 Table to represent the relationship between husband's occupation and size of businesses.................................................... 137

TABLE 4.22 Number of businesses owned..................................... 138

TABLE 4.23 Table to represent the number of women owned registered units.........139

TABLE 4.24 Table to represent the source of seed capital.........................141

TABLE 4.25 Table to represent the ease to start a business for women............... 142 
TABLE 4.26 Table to represent 'Have you ever attended EDP?'

TABLE 4.27 Table to represent 'Is EDP beneficial for women to make them better entrepreneurs in Gujarat?'

TABLE 4.28 Table to represent 'Effect of EDP?'

TABLE 4.29 Table to represent 'Source of Continuous Support'

TABLE 4.30 Table to represent 'Enabling Factors' for women entrepreneurs 150

TABLE 4.31 Table to represent the Relationship between Frequency of Respondents who believe Education as an Enabling Factor for Women Entrepreneurs and Respondents who face the problem of Lack of Technological Skills as an Effectual Factor. .153

TABLE 4.32 Table to represent 'Financial Problems' 154

TABLE 4.33 Table to represent 'Personal Problems' faced by women. .156

TABLE 4.34 Table to represent 'Social Problems' faced by women entrepreneurs....157

TABLE 4.35 Table to represent 'Problems related to raw material' for women entrepreneurs

TABLE 4.36 Table to represent 'Marketing Problems' faced by women. 160

TABLE 4.37 Table to represent 'Labor/Employee related problems' faced by women entrepreneurs

TABLE 4.38 Table to represent 'Problems related to Managerial Abilities' faced by women entrepreneurs 
TABLE 4.39 Table to represent 'Problems related to Infrastructural Difficulties' faced by women entrepreneurs

TABLE 4.40 Table to represent 'Problems related to Technological Difficulties' faced by women entrepreneurs

TABLE 4.41 Table to represent 'Problems related to Government Support' faced by women entrepreneurs

TABLE 4.42 Consolidated view at Problems Faced by Women Entrepreneurs in the State of Gujarat.

TABLE 4.43 Table to represent the relation between dual role in home and business as a problem and age of respondent as an effectual variable

TABLE 4.44 Table to represent the relation between Poor Knowledge of Government Support Schemes and Ignorance about Banking Procedures and Formalities among Women Entrepreneurs in the State....

TABLE 4.45 Table to represent the relationship between problem of ignorance about banking procedures and formalities and Age as an effectual Variable among Women Entrepreneurs in the State.

TABLE 4.46 Table to represent the relationship between Poor knowledge of Financial Management and Education level of the Women Entrepreneurs

TABLE 4.47 Table to represent the relationship between Lack of Technological Skills as a problem and Absence of Need of Achievement among Women Entrepreneurs as an effectual variable in the State.

TABLE 4.48 Table to represent 'Prospective factors' that contribute to women entrepreneurship in Gujarat.

TABLE 4.49 Table to represent 'Prospective Industry' for women entrepreneurs in Gujarat.

TABLE 4.50 Table to Represent the Relationship between the 'Prospect in Service Industry' and 'Type of Current Industry' in which Women Entrepreneur own business. 
TABLE 4.51 Table to Represent the Relationship between Perception of Women Entrepreneurs to have Better Prospects in Manufacturing Industry \&Their Current Industry in Which They Actually Run their Current Bus.........184

TABLE 4.52 Table to represent 'Prospective Business Activity' for women entrepreneurs in Gujarat............................................185

TABLE 4.53 Table to represent 'Prospective Business Activity-Others' for women entrepreneurs in Gujarat........................................187 


\section{List of Charts}

CHART 1.1 Effect of New Business Formation on Employment

.03

CHART 1.2 Growth of Indian Micro, Small and Medium Enterprises Sector (19902003). .28

CHART 1.3 Comparing growth of SME sector to Industrial Output. .29

CHART 1.4 Gender GEDI - 2013 vs Gender GEDI - 2014. .38

CHART 4.1 Bar chart to represent the age distribution of women entrepreneurs 110

CHART 4.2 Bar Chart to Represent the Education Level of Women Entrepreneurs...111

CHART 4.3Pie Chart to Represent the Marital Status of Women Entrepreneurs. 112

CHART 4.4 Bar Chart to Represent Husband's Education 113

CHART 4.5 Bar Chart to Represent Husband's Occupation.

CHART 4.6 Bar Chart to Represent Father's Education 116

CHART 4.7 Bar Chart to Represent Father's Occupation....

CHART 4.8 Bar Chart to Represent Mother's Education.

CHART 4.9 Bar Chart to Represent Mother's Occupation 120

CHART 4.10 Pie Chart to represent did women entrepreneur receive any help from those family members' who are already into business?.....

CHART 4.11 Bar Chart to represent mode to start business.

CHART 4.12 Bar Chart to represent the reason to start business

CHART 4.13 Bar Chart to represent the year of establishment

CHART 4.14 Bar Chart to represent type of industry. 129 
CHART 4.15 Bar Chart to represent type of manufacturing activity

CHART 4.16 Bar Chart to represent type of service activity.

CHART 4.17 Pie Chart to represent percentage wise distribution of size of women owned business

CHART 4.18 Bar Chart to represent number of businesses owned by individual woman entrepreneur. 138

CHART 4.19 Pie Chart to represent number of women owned registered units 140

CHART 4.20 Bar Chart to represent the source of seed capital.

CHART 4.21 Pie Chart to represent the ease to start a business for women. 143

CHART 4.22 Pie Chart to represent 'Have you ever attended EDP?' 144

CHART 4.23 Pie Chart to represent 'Is EDP beneficial for women to make them better entrepreneurs in Gujarat?' 146

CHART 4.24 Pie Chart to represent 'Effect of EDP'

CHART 4.25 Bar Chart to represent 'Source of Continuous Support' 149

CHART 4.26 Bar Chart to represent 'Enabling Factors' for women entrepreneurs.....151

CHART 4.27 Bar Chart to represent 'Financial Problems' 154

CHART 4.28 Bar Chart to represent 'Personal Problems' faced by women. 156

CHART 4.29 Bar Chart to represent 'Social Problems' faced by women. 158

CHART 4.30 Bar Chart to represent 'Problems related to raw material' for women entrepreneurs

CHART 4.31 Bar Chart to represent 'Marketing Problems' faced by women entrepreneurs

CHART 4.32 Bar Chart to represent 'Labor/Employee related problems' faced by women entrepreneurs. 
CHART 4.33 Bar Chart to represent 'Problems related to Managerial Abilities' faced by women entrepreneurs

CHART 4.34 Bar Chart to represent 'Problems related to Infrastructural Difficulties' faced by women entrepreneurs.

CHART 4.35 Bar Chart to represent 'Problems related to Technological Difficulties' faced by women entrepreneurs. 167

CHART 4.36 Bar Chart to represent 'Problems related to Government Support' faced by women entrepreneurs.

CHART 4.37 Bar Chart to represent 'Prospective factors' that contribute to women entrepreneurship in Gujarat.

CHART 4.38 Bar Chart to represent 'Prospective Industry' for women entrepreneurs in Gujarat.

CHART 4.39 Bar Chart to represent 'Prospective Business Activity' for women entrepreneurs in Gujarat. 


\section{List of Appendices}

Appendix A-Interview Schedule - English

Appendix B-Interview Schedule - Gujarati

Appendix C - List of Publications 


\section{CHAPTER-I}

\section{Introduction to Entrepreneurship, MSMEs \& Women Entrepreneurship}

\subsection{Introduction}

Entrepreneurship has gradually been given tremendous importance especially in contemporary times when global economy is facing misbalance due to interconnected markets in the era of globalization. Rama (2003) considers, to be competitive in this era, especially developing economies have to rework on existing trade difficulties, eliminate the legal control, state owned enterprises should be privatized and over staffing in bureaucratic systems should be reduced and if these reforms are worked upon then the economy would encounter state of rising unemployment. Naidu (2009) advocates that India has 300 million youth and against this number she (India) has only 100 million jobs that are being created. This leads to an employment gap of 200 million. Substantial rise in unemployment rate has been observed from 6.8 per cent in the year 2001 to a whopping 9.6 per cent in the year 2011 (Punj, 2016).

In a country like India, where due to its soaring population Okun's law (Knoteck, 2007) is appositely applicable which suggests growth slowdown coincides with rising unemployment, also according to Arthur Okun's Law, unemployment rate of any nation is the clear representation of growth rate of the economy (Gupta, 2002), problem solving 
to unemployment is of utmost importance so that the economic growth can be balanced. One such solution has been suggested by Faria, Cuestas \& Gil-Alana (2009) in their paper 'Unemployment and entrepreneurship: A cyclical relation?' wherein it has been presented that unemployment is negatively related to the rise in the strength of entrepreneurial ventures or entrepreneurship. This can be shown in the given equation where variation in unemployment rate over time $u_{e}=d u / d t$ (where $u_{e}$ is unemployment) is associated with entrepreneurship (e) through function $f(\mathrm{e})$ and can be represented by -

$\mathrm{u}_{\mathrm{e}}=-f(\mathrm{e})$

The given equation is developed with an assumption that new firm start-ups increases competition, by the generation of new products and services, the increasing competition is evident with improved quality of products and services which is only achieved when the firm has upgraded technology and managerial skills. Upgraded technology and managerial skills are most likely to be achieved by hiring new employees. This shows explicit decrease unemployment rate.

In the same paper the reverse effect is also represented by -

$\mathrm{e}_{\mathrm{n}}=\mathrm{u}_{\mathrm{e}}-g(\mathrm{e})$

$e_{n}=$ New entrepreneurial venture

$\mathrm{u}_{\mathrm{e}}=$ Unemployment

$g(\mathrm{e})=$ Impact of existing firms

The above equation shows negative impact of existing firm $g$ (e) on creation of new entrepreneurial venture $e_{n}$ because of the belief that creation of new business is lower in environment of stiff business competition and hence rising unemployment. This literature shows a cyclical relationship between unemployment and entrepreneurship. In the abovementioned and many other researches entrepreneurship has been accepted as an instrumental solution to the problem of unemployment as it focuses upon the creation of job (Bokhari, 2012). It can be supported by the study conducted by GEM's Adult Population Surveys from the years 2004 to 2009. Under this study when asked to the nascent entrepreneurs the number of employees that they expect to hire in the duration of upcoming five years, it emerged that 7 out of 10 respondents accepts the likeliness of some job creation, whereas 14 per cent of all new start-up attempter's belief that they 
will create 20 or more jobs and 44 per cent of them expected that they will create 5 or more jobs. According to the Kritikos in his article it is presented that in initial years of new business establishment there is usually a growth in the job opportunities, hence results in rise in employment in short run. This phase is followed by a downturn/stagnation phase in medium term because in this phase old established firms finds the competition difficult and lays off staff leading to fall or stagnation in job opportunities. But in long run increased competitiveness raises the demand for new product and hence contributes to accelerated job opportunities. This is also termed as Sshaped effect of new enterprises on employment opportunities over time as shown in Chart 1.1 (Kritikos, 2014).

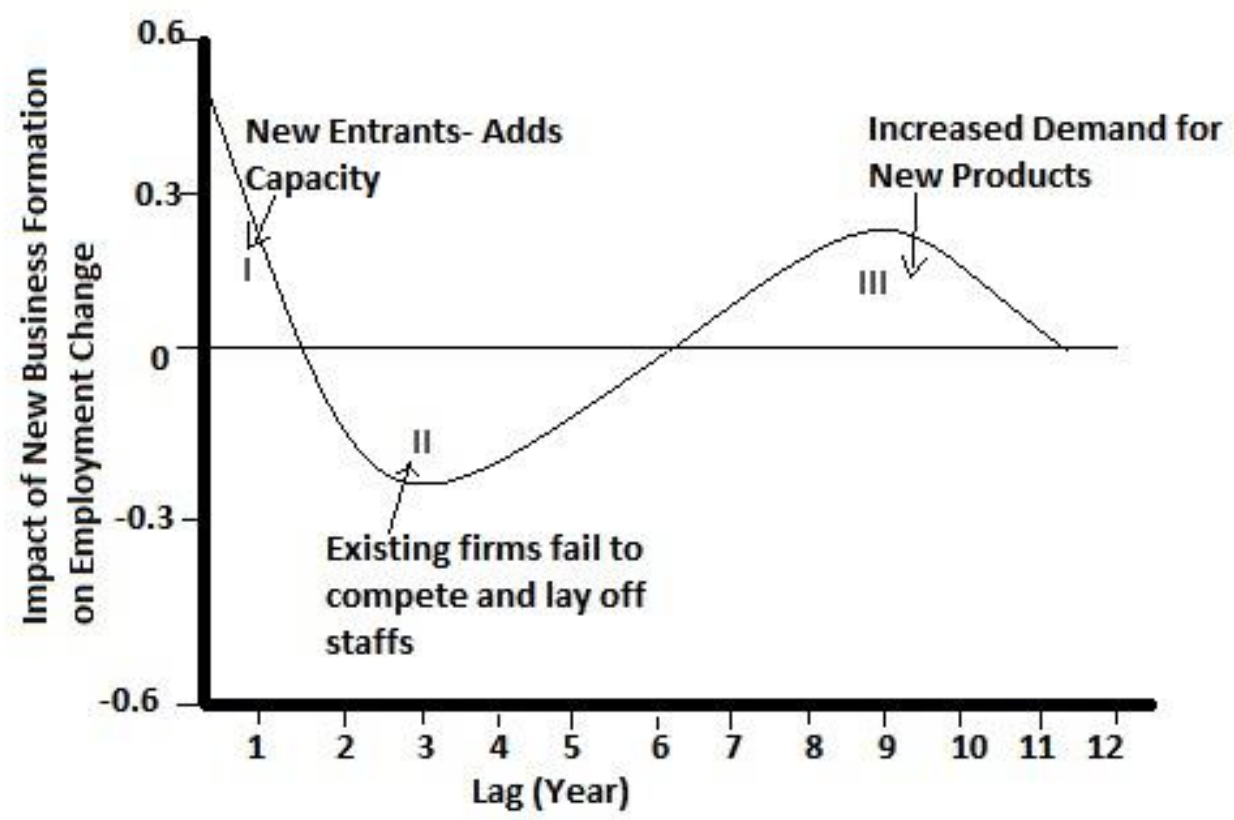

Source: Fritsch, M. "How does new business formation affect regional development? Introduction to the special issue.” Small Business Economics 27 (2008): 245-260 [4]. Cited by Kritikos (2014)

CHART1.1

Effect of New Business Formation on Employment

These arguments support that unemployment can be one of the major reasons which make policymakers to accentuate the importance of entrepreneurship and make attempts to encourage larger section of the society including youth, SC, ST, women and retired employees to take up entrepreneurship as an occupation by introducing numerous recent schemes like Start-up India, Make in India, Trade Related Entrepreneurship Assistance and Development (TREAD), Stand-up India, Micro Units Development and Refinancing 
Agency Scheme (MUDRA), Mahila Coir Scheme and many more. Besides unemployment being the most important driving force for the policymakers to think and rethink about ways in which the concept of entrepreneurship can be instilled among the larger section of the society, there are many other factors which has lead to this. The main reasons for this can be listed as under:-

1. Entrepreneurship becomes a medium to commence innovation and hence accelerates growth in the given economy (Kritikos, 2014).

2. Entrepreneurship intensifies the level of competition among the industrial players at a given point of time ((Kritikos, 2014).

3. New businesses boost productivity (Kritikos, 2014).

4. Entrepreneurship becomes instrumental in bringing structural change in existing market by replacing sclerotic firms and with the introduction of whole new set of customers with varied set of needs and hence becomes the engine of future growth process (Kritikos, 2014).

5. Shrinking regularized employment inhibits employment opportunities to majority of youth which becomes a driving force for them to start looking for alternatives that provides the opportunity to meet their need of income generation - starting a new venture and enter into the world of entrepreneurship becomes the most promising alternative for them which they look for.

6. Growth of knowled ge economy has generated such market opportunities which appear to be more effectively build up by new entrants than the existing firms. The transition towards much hyped knowledge economy is believed to be key factor for the metamorphosis of economy of a nation to entrepreneurial economy (Stam \& Garnsey, 2007).

India has continuously been observed marching towards achieving a tag of acing nations economically. The abovementioned factors have also driven India to explore opportunities with respect to entrepreneurship for an uninterrupted growth of the nation. To have an unambiguous conceptual understanding let us discuss few important definitions pertaining to this study. 


\subsection{Conceptual insights on the frequently used terminologies}

\subsubsection{Entrepreneurship}

The US Department of State suggests the origin of entrepreneurship in 1700's and thereafter various theorists have contributed to define entrepreneurs, entrepreneurship and entrepreneurial activity. The term 'Entrepreneur' is drawn from a French verb 'Entreprendre' which stands for 'to undertake' (Desai, 2014). Scholars are observed making continuous efforts to define entrepreneurs and entrepreneurship ever since its origin.

There are mainly two beliefs regarding definition of entrepreneurship, in the first belief Bygrave and Hoafer (1991) as reported by Aspromourgos (2012) suggests that there lack consensus on the concept of entrepreneurship. Hence in their works the researcher needs to highlight their understanding of the term 'Entrepreneurship' with which the research is being conducted. Secondly as pointed by Henkerson in his work 'Entrepreneurship and Institutions' and cited by Naude (2010) entrepreneurship has many definitions given by number of authors on basis of their comprehension which is generally inclined towards their respective field of study ranging from social anthropology to organizational theory to mathematical economics. In both the cases it is advised to the scholars to clearly define entrepreneurship as it has been considered while conducting their study. In the quest of defining 'Entrepreneurship' we will first go through the definitions stated by various stalwarts in this field.

Traditionally Jean Baptiste Say is considered to coin the term Entrepreneur and advancing it further but originally the French economist Richard Cantillon had used the term entrepreneurship for the first time in about 1730s in his Essai sur la Nature du Commerce en Général (Miryala \& Aluvala, 2015)by more or less picturing 'entrepreneurship' as 'self employment of any nature' and called 'entrepreneur' as the one who takes risk by buying goods at a given price and sells them at an uncertain prices infuture (Ahmad \& Seymour, 2008). 
In his paper, Aspromourgos (2012) also supports the argument that the genes is of Theory of Entrepreneurship is in Richard Cantillon's Essai sur la Nature du Commerce en Général (1755) - "[I] may be laid down that except the Prince and the Proprietors of land, all the Inhabitants of a State...can be divided into two classes, undertakers [Fr., Entrepreneurs] and Hired people; and that all the Undertakers are as it were on unfixed wages and the others on wages fixed so long as they receive them though their functions and ranks may be very unequal. The General who has his pay, the Courtier his pension and the Domestic Servant who has wages all fall into the last class. All the rest are Undertakers, whether they set up with a capital [un fond] to conduct their enterprise, or are Undertakers of their own labour without capital, and they may be regarded as living in uncertainty [I'incertain]; the Beggars even and the robbers are Undertakers of this class."

Richard Cantillon (1755 [1931]:5)

It is worth mentioning that Anthony Breer noted that while Cantillons perception with regard to Entrepreneurs is of 'risk taker', Say's perception portrays entrepreneurs as 'planner' (Miryala \& Aluvala, 2015).

Jean-Baptiste Say (1816) emphasized upon the role of entrepreneurs by considering them to be one who combines all means of production and gives a value to them. Other eminent scholars like Adam Smith, Alfred Marshall and Frank Knight including J B Say by retaining two soul features of entrepreneurs i.e. risk taking and profit making, further added to Cantillon's explanation of entrepreneurs by adding features like leadership, organization as a feature and most importantly adjudged it to be the fourth factor of production (Ahmad \& Seymour, 2008)

According to Schumpeter (1934) entrepreneurs are those who put into practice entrepreneurial transitions in marketplace by bringing innovations in the following five arenas (Ahmad \& Seymour, 2008):-

1) New or improvised goods

2) Innovative methods of production

3) Inventing a different set of marketplace

4) Inventing a new supply source

5) Developing novice business management processes 
The diversified nature of entrepreneurship is cogently reflected in the varied definitions proposed by scholars like 'Creation of Organization' (Gartner, 1988), 'Creative destruction or carrying out new combinations' (Schumpeter, 1934), 'Exploitation of opportunities' (Kirzner, 1973), 'Bearing uncertainty' (Knight, 1921) and 'Bringing together factors of production' (Say, 1803) are few as documented by Mokaya, Namusonge and Sikaleih, 2012. Table 1.1, as sourced from the work 'Defining the Entrepreneur' by Louis Jacques Filion, enlists 15 most frequently utilized elements while defining 'Entrepreneur' which have been enlisted by scrutinizing the relevant literatures available on entrepreneurship (Filion, 2011).

TABLE 1.1

The elements mentioned most frequently in definitions of the term 'Entrepreneur'

\begin{tabular}{|c|c|}
\hline $\begin{array}{l}\text { Elements defining the } \\
\text { 'Entrepreneur' }\end{array}$ & Authors \\
\hline Innovation & $\begin{array}{l}\text { Schumpeter (1947); Cochran (1968); Drucker (1985); } \\
\text { Julien (1989;1998) }\end{array}$ \\
\hline Risk & $\begin{array}{l}\text { Cantillon (1755); Knight (1921); Palmer (1971); Reuter } \\
\text { Ltd (1982); Rosenberg (1983) }\end{array}$ \\
\hline $\begin{array}{l}\text { Coordination of resources for } \\
\text { production; organizing factor } \\
\text { of production or of the } \\
\text { management of resources }\end{array}$ & $\begin{array}{l}\text { Ely and Hess (1893); Cole (1942; and in Aitken 1965); } \\
\text { Belshaw (1955); Chandler (1962); Leibenstein (1968); } \\
\text { Wilken (1979); Pearce (1981); Casson (1982) }\end{array}$ \\
\hline Value creation & $\begin{array}{l}\text { Say (1815; 1996); Bruyat and Julien (2001); Fayolle } \\
\text { (2008) }\end{array}$ \\
\hline $\begin{array}{l}\text { Projective and visionary } \\
\text { thinking }\end{array}$ & Longenecker and Schoen (1975); Filion (1991; 2004) \\
\hline Focus on action & Baty (1981) \\
\hline Leadership & Hornaday and Aboud (1971) \\
\hline $\begin{array}{l}\text { Dynamo of the economic } \\
\text { system }\end{array}$ & $\begin{array}{l}\text { Weber (1947); Baumol (1968); Storey (1982); Moffat } \\
\text { (1983) }\end{array}$ \\
\hline Venture Creation & $\begin{array}{l}\text { Collins et al. (1967); Smith (1967); Collins and Moore } \\
\text { (1970) Brereton (1974); Komives (1974); Mancuso (1979); } \\
\text { Schwartz (1982); Carland et al. (1984); Vesper (1990) }\end{array}$ \\
\hline Opportunity recognition & $\begin{array}{l}\text { Smith (1967); Meredith et al.(1982); Kirzner (1983); } \\
\text { Stevenson and Gumpert (1985); Timmons (1989); Dana } \\
\text { (1995); Shane and Venkataraman (2000); Bygrave and } \\
\text { Zacharakis (2004); Timmons and Spinelli (2004) }\end{array}$ \\
\hline Creativity & Zaleznik and Kets de Vries (1976); Pinchot (1985) \\
\hline Anxiety & Lynn (1969); Kets de Vries (1977; 1985) \\
\hline Control & McClelland (1961) \\
\hline Introduction of change & Mintzberg (1973); Shapero (1975) \\
\hline Rebellion/delinquency & Hagen (1960) \\
\hline
\end{tabular}


National Knowledge Commission, India, for the purpose of their study defined entrepreneurship as (Goswami, Dalmia and Pradhan, 2008)-

"Entrepreneurship is the professional application of knowledge, skills and competencies and/or of monetizing a new idea, by an individual or a set of people by launching and enterprise de novo or diversifying from an existing one (distinct from self employment as in a profession or trade) thus to pursue growth while generating wealth, employment and social good".

This definition gives a narrow outlook to entrepreneurship than its practical sense that has been practically observed at grass root level. A Consortium of universities started Global Entrepreneurship Monitor (GEM), a global study, in 1999 to analyze the level of entrepreneurship in the studied countries (70 in number in 2013's Report). GEM 2013 Global report documents the direct implications and contribution of different types of entrepreneurial ventures, even the ventures which are accompanied by less ambitious business activities leading to limited to no growth, towards socio-economic development. Further to enhance comprehension its detailed that many entrepreneurs world-wide take up different business activities because of lack of other income generation opportunity and because indulging into self employment activities offers them opportunity to take care of family expenditure and needs. This kind of entrepreneurship is most prominent in developing countries (Amoros and Bosma, 2014).

\section{Definition as used for the purpose of the study}

Therefore for the purpose of our study 'GEM 2013 Global Report' definition is suitable which defines entrepreneurship as (Amoros and Bosma, 2014)-

"Any attempt at new business or new venture creation, such as self employment, a new business organization, or expansion of an existing business, by an individual, a team of individuals, or an established business" 


\subsubsection{Micro, Small, Medium Enterprises (MSMEs)}

MSME have direct implication on development of entrepreneurial ventures and diversification of industrial sector. MSME sector encompasses entire non-agricultural segment of National Economy (Sanjeevan, 2012).MSME Act, 2006 brought together varied set of industrial activities hitherto classified under Small Scale Industries (SSI), Small Scale Business Sector Enterprise, Village and Cottage Industries to make MSME highly heterogenic in nature (Sanjeevan, 2012). This sector now encompasses all kinds of non-agricultural activities from a very small village, town to megalopolitan cities. The heterogeneity of this sector is reflected in different features enterprises like in the size of business which may operate in different markets (rural, urban, local, regional, national and international), with varied level of skills, capital, sophistication and with different kind of growth orientation in organized or unorganized sector of the economy (OECD, 2004). MSME very well covers those self employed / own account entrepreneurs and household enterprises that organize the economic activity at a very low scale and in an informal manner. They may be tiny in terms of its contribution towards the Gross Domestic Product (GDP) but the volume in which they exist (as shown in Fig.1.1) makes it difficult to ignore its contribution towards economy (Sanjeevan, 2012). 


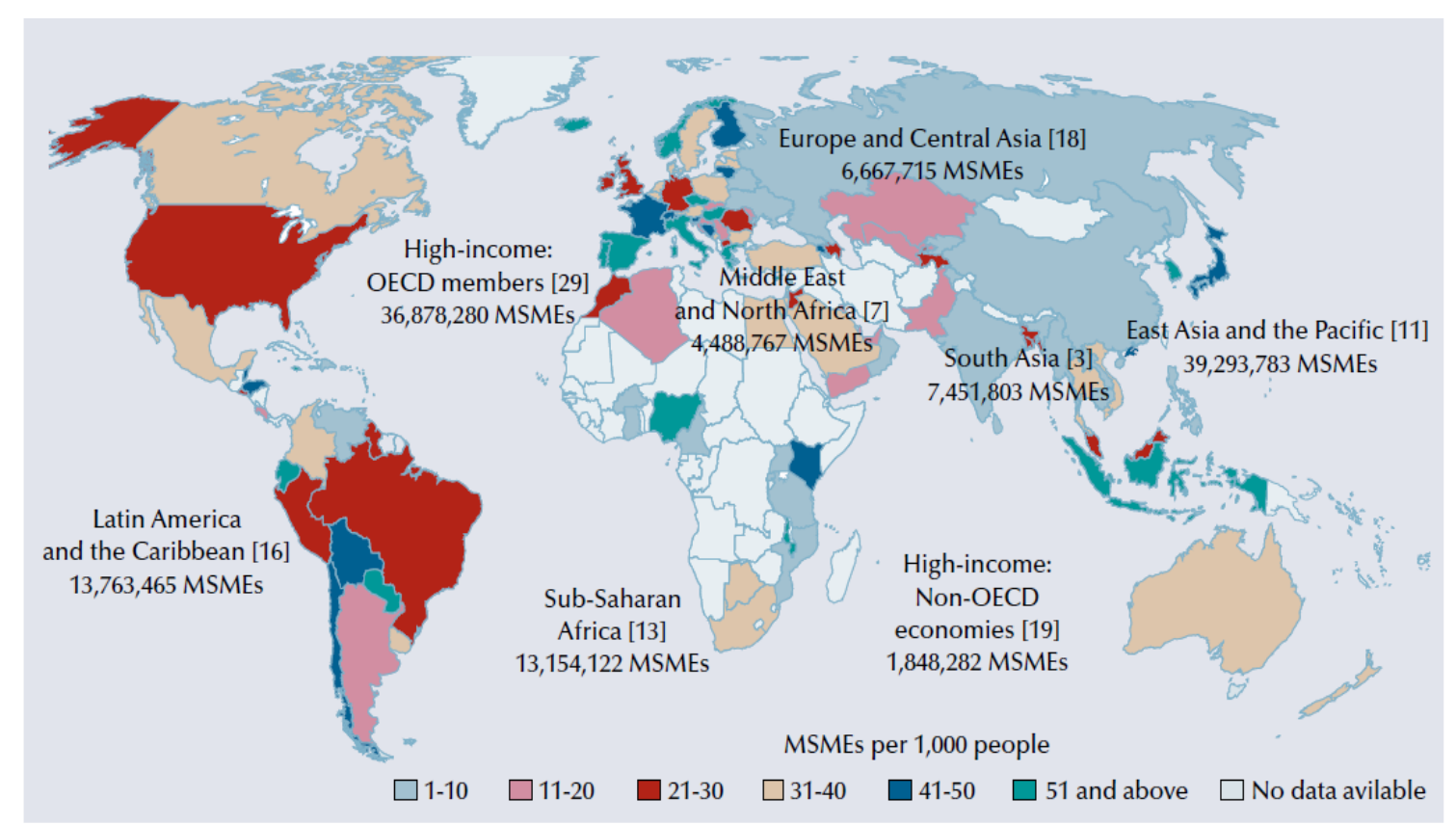

Sources- MSME Country Indicators as cited in IFC, 2010

Note - Name of Region [\#] signifies the number of economies from the region included in the analysis. The figure uses the most recent data available after 2000. The figure use data for 116 countries.

FIG 1.1

\section{MSME Density across the World}

It is worth noting that statistical definition of SMEs differs from country to country (as shown in Table 1.2) and are generally defined on the basis of number of employees, value of assets and/or value of sales or investment in plant and machinery. For the comfort of data collection the EU and OECD uses number of employees as the basis to bifurcate the category of small and medium enterprises (OECD, 2004). 
TABLE 1.2

SME Shares of Manufactured Exports in Developing and OECD Economies

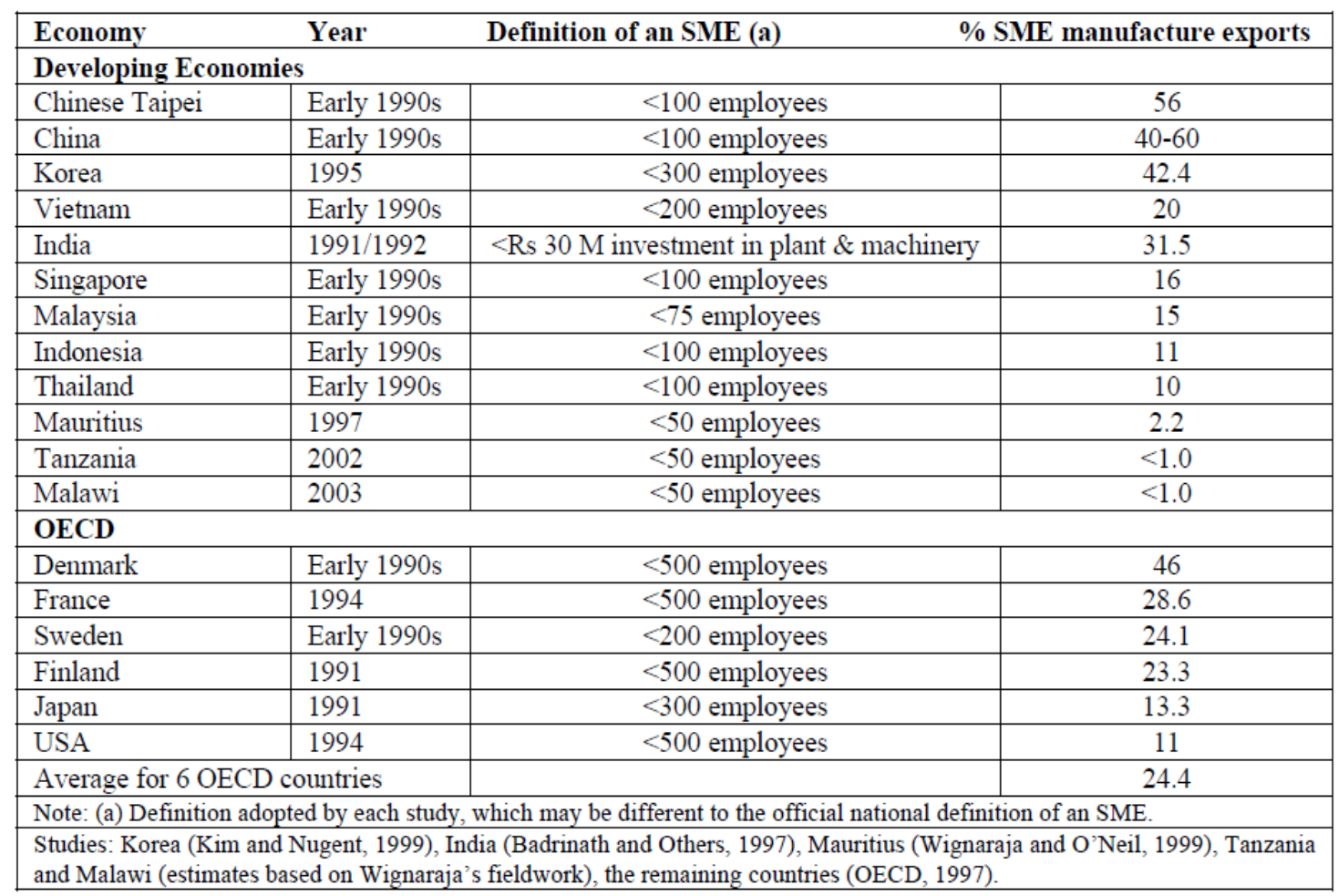

Source - Wignaraja, Ganesh (2003) as cited by OECD (2004)

This table clearly depicts that SME's play no less than crucial role in employment, income generation and export revenues (OECD, 2004).

As per the quick estimates of $4^{\text {th }}$ All India Census of MSMEs some statistics with regard to MSMEs in India are (MSME, 2012) -

i. India has 26 million MSMEs which creates employment to an estimated 60 million people.

ii. MSME sector contributes to 45 per cent of manufacturing output and 40 per cent to total of export sector in national economy.

iii. MSME has recorded contribution of 8 per cent towards the total GDP of the nation and has registered a growth rate of 10.8 per cent.

iv. Out of these 26 million MSMEs only 1.5 million are registered and rest (94 per cent) are unregistered enterprises. 
v. 55 per cent of these MSMEs are mainly distributed in Uttar Pradesh, Maharashtra, Tamil Nadu, West Bengal, Andhra Pradesh and Karnataka.

vi. MSME accounts for the production of over 6000 products in the country.

The role of MSME becomes more inclusive when it becomes an instrument to transform the economic status of few special segments of the society like women workforce, unemployed youth, SC/STs, physically challenged people and some traditional industries like handicraft etc.

This study focuses on one such segment i.e. women entrepreneurs. In India 26.61 lakhs of women owned enterprises forms 7.36\% per cent of total MSMEs (MSME,2014-15) which contributes to 3.09 per cent of industrial output and gives employment to about 8 million people (IFC, 2014). Statistically 98 per cent of women-owned enterprises are micro-enterprises as per this report. This is the pioneer rationale for the researcher to study the women entrepreneurs of MSME sector. The definition for MSME for the purpose of this study is as under.

\section{Definition as used for the purpose of the study}

MSME Act, 2006 defines Micro, Small and Medium Enterprises as notified, vide S.O. 1642(E) dtd.29-09-2006 is as shown in Table 1.3 as follows:-

TABLE 1.3

Definition of MSMEs as per MSME Act, 2006

\begin{tabular}{|c|c|c|}
\hline \multicolumn{2}{|c|}{ Definitions as per MSME Act, 2006 } \\
\hline & $\begin{array}{c}\text { Manufacturing (Investment in } \\
\text { Plant and Machinery) }\end{array}$ & $\begin{array}{c}\text { Service (Investment in } \\
\text { equipments) }\end{array}$ \\
\hline Micro & Does not exceed Rs. 25 lakh & Does not exceed Rs. 10 lakh \\
\hline Small & More than Rs. 25 lakh but does & More than Rs. 10 lakh but does \\
& not exceed Rs. 5 crore & not exceed Rs. 2 crore \\
\hline Medium & More than Rs. 5 crore but does & More than Rs. 2 crore but does \\
& not exceed Rs. 10 crore rupees & not exceed Rs 5 core \\
\hline
\end{tabular}

Source - Development Commissioner-Micro Small Medium Enterprises. Government of India 
Manufacturing Enterprises: - Enterprises betrothed in manufacturing / production of goods pertaining to any industry specified in the first schedule of the Industries (Development and Regulation) Act, 1951.

Service Enterprises: - Enterprises betrothed in the provision of services and are defined in terms of investment made on equipment.

\subsubsection{Women Entrepreneurship}

1900s brought numerous transformations especially in global labor market arena. The great depression in 1930s and follow-up World War II period marked women's initial entry to the labor market, though the reasons in both the cases were altogether different. While in 'The Great Depression', women entered labor market to fulfill the family's requirements which were difficult to meet due to low wages of husband, the 'World War II' experienced women's entry in labor market to compensate the absence of male counterpart due to their indulgence in prolonged and extensive war. The effect of various revolutionary movements like Civil Rights Movement, the Labour Movement and Women's Movement in United States mushroomed to different parts of globe (SmithHunter, 2013). This became reason for women to start taking interest in different facets of life from education to politics, and from societal to labor market arenas.

98 per cent of Indian women entrepreneurs are in micro-enterprises (MSME, 2012), this fact marks the pertinent role MSME sector plays to project the entrepreneurial potential the 'better half'1 (48 per cent of women in Indian Population as per Census 2001) of the Indian society has. MacRea (2005) as cited by (Smith-Hunter, 2013) contends that entrepreneurship becomes a preferred outlet for women because of number of disadvantages they face in the mainstream labor market like glass ceiling, unequal wages, inaccessibility to men dominated industries (in which no women are hired purposely because of preconceived notions about women being less productive) and sexual harassments are few to mention (Smith-Hunter, 2013). The evolution and role

\footnotetext{
${ }^{1}$ 'Better Half' refers to women section of the Indian society on basis of gender composition in population.
} 
played by women entrepreneurs in Indian society has been elaborated in greater detail later in section 1.5 of this chapter.

Government of India as cited by (Sharma, 2013) defined women entrepreneurs on basis of their stake in the firm and employment created, and has been defined as -

"An enterprise owned and controlled by a women having a minimum financial interest of 51 per cent of the capital and giving at least 51 per cent of employment generated by enterprise to women"

Practically this definition faces two major problems (OECD, 2004): -

a. Can we call women taking part in family businesses as 'Entrepreneurs'?

b. What can we term the women partner of enterprises having mixed sex owners?

Kamala Singh as cited (Sharma, 2013) has defined woman entrepreneurs as -

"A woman entrepreneur can be defined as a confident, innovative and creative women capable of achieving self economic independence individually or in collaboration, generates employment opportunities for others through initiating, establishing and running the enterprise by keeping pace with her personal, family and social life"

This definition to a larger extent meets the explanation of women entrepreneurs in practical scenario.

\section{Definition as used for the purpose of the study}

Furthering the definition of 'Entrepreneurship' (given by 'GEM 2013 Global Report' which has been mentioned in section 1.2.1) in terms of Women Entrepreneurship for the purpose of this study, author defines women entrepreneurs as follows: -

"A women entrepreneur in MSME sector can be defined as that economic entity who is vigorously involved in non-agricultural industrial activity, owns and manages the functions of the business enterprise, new or already established by investing most of the day's time or otherwise towards business activities, invests her own (or borrowed) capital resources, even if in lower proportion (in case of micro enterprises of informal 
sector), identifies opportunity and bear risk to organize and mobilize the factors of production and the resources of the enterprise, individually as a self-employed or in collaboration or as a member of a family business and produces goods/services to the customers with a primary motive of profit maximization is termed as Women Entrepreneur"

Profit maximization has been mentioned as primary motive for the reason that MSME not only includes mainstream businesses of organized sector but also includes microenterprises of highly unorganized sector like hawkers, home-based business women etc who's main purpose of being into business is to extract livelihood from the business activity for sole purpose of survival.

\subsection{THEORY OF ENTREPRENEURSHIP}

There are basically three schools of thought with regard to portray the nature and feature of entrepreneurship - a) Economic theory of entrepreneur b) Sociological theory of entrepreneur and c) psychological theory of entrepreneur. These theories have been discussed in detail in the following sections.

\subsubsection{Economic Theories of Entrepreneur}

Economists while explaining a economic system at a particular time in the history explained the role of entrepreneurs in construction of economy. These concepts today form the basis to explain the theories of entrepreneurship. Table 1.4 summarizes the economical thought of thinkers as follows- 
TABLE 1.4

Economic Theories of Entrepreneurship

\begin{tabular}{|c|c|}
\hline Authors & Theoretical Crux \\
\hline $\begin{array}{l}\text { Richard Cantillon } \\
\text { (1755) }\end{array}$ & $\begin{array}{l}\text { 'Entrepreneurs work on uncertain wages, whether they establish, } \\
\text { with or without capital' (Cherukara \& Manalel, 2011) }\end{array}$ \\
\hline $\begin{array}{l}\text { Jacques Turgot, } \\
1766\end{array}$ & $\begin{array}{l}\text { 'Entrepreneur is the outcome of a capital investment decision' } \\
\text { (Cherukara \& Manalel, 2011) }\end{array}$ \\
\hline $\begin{array}{l}\text { Nicholas Baudeau, } \\
1771\end{array}$ & $\begin{array}{l}\text { First one to suggest the function of entrepreneur as innovator } \\
\text { (Cherukara \& Manelal, 2011). Also emphasized on the role of } \\
\text { knowledge and information which makes an entrepreneur an } \\
\text { economic agent. }\end{array}$ \\
\hline $\begin{array}{l}\text { Jean Baptiste Say, } \\
1803\end{array}$ & $\begin{array}{l}\text { 'Entrepreneur coordinates and combines the factors of } \\
\text { production.' (Cherukara \& Manalel, 2011) }\end{array}$ \\
\hline $\begin{array}{l}\text { Alfred Marshall, } \\
1881\end{array}$ & $\begin{array}{l}\text { According to him there exist a perfect market and hence there is } \\
\text { no scope of extra opportunities for profit; less exploitation of labor } \\
\text { in production process; everyone earns his marginal contribution to } \\
\text { production and national income. (Bula, 2012) }\end{array}$ \\
\hline $\begin{array}{l}\text { Frederic Barnard } \\
\text { Howley, } 1907\end{array}$ & $\begin{array}{l}\text { Enterpriser has the key function of production process- decides } \\
\text { the combination of means of production; operates in uncertainty } \\
\text { (Cherukara \& Manalel, 2011). }\end{array}$ \\
\hline $\begin{array}{l}\text { Joseph Alois } \\
\text { Schumpeter, } 1928\end{array}$ & $\begin{array}{l}\text { Creative destruction (Down, 2010); Create new ways of doing } \\
\text { things in starting innovative businesses, which bring them rewards } \\
\text { in the form of profits from the brief monopolies they create in } \\
\text { these new markets. (Down, 2010) }\end{array}$ \\
\hline $\begin{array}{l}\text { Frank Knight, } \\
1921\end{array}$ & $\begin{array}{l}\text { Highlighted the distinction between risk and uncertainty. } \\
\text { Emphasizes on the ability to make judgement to earn profit } \\
\text { (Down, 2010). }\end{array}$ \\
\hline & Austrian School of thought \\
\hline $\begin{array}{l}\text { Ludwig Von } \\
\text { Mises, } 1949\end{array}$ & $\begin{array}{l}\text { Misesian entrepreneur is product of structure of his mind and } \\
\text { experiences (Cherukara \& Manalel, 2011). }\end{array}$ \\
\hline $\begin{array}{l}\text { Friedrich Hayek, } \\
1937\end{array}$ & $\begin{array}{l}\text { Developed Price Theory; Emphasized on alertness and knowledge } \\
\text { for opportunity recognition (Barreira, 2010) }\end{array}$ \\
\hline $\begin{array}{l}\text { G.L.S. Shackel, } \\
1970\end{array}$ & $\begin{array}{l}\text { Emphasized entrepreneurs to be a decision maker; Entrepreneur is } \\
\text { the product of decisions taken in uncertainties and not knowledge } \\
\text { (Cherukara \& Manalel, 2011). }\end{array}$ \\
\hline $\begin{array}{l}\text { Israel Kirzner, } \\
1997\end{array}$ & $\begin{array}{l}\text { 'I view the entrepreneur not as a source of innovative ideas ex } \\
\text { nihilo (out of nothing), but as being alert to the opportunities that } \\
\text { exist already and are waiting to be noticed' Kirzner 1973:74 as } \\
\text { cited by (Down, 2010). }\end{array}$ \\
\hline T.W.Schultz, 1975 & $\begin{array}{l}\text { Schultz deems them to be the real entrepreneur who can perform } \\
\text { reallocation of resources in the situation of disequilibrium (Bula, } \\
\text { 2012). }\end{array}$ \\
\hline \multicolumn{2}{|c|}{ Entrepreneur in Mainstream Economics (Cherukara \&Manalel, 2011) } \\
\hline $\begin{array}{l}\text { William Baumol, } \\
1995\end{array}$ & $\begin{array}{l}\text { Neo-Classical entrepreneurs are 'Automation Maximizers'; } \\
\text { Entrepreneurship has been observed in numerous societies } \\
\text { throughout history; its presence has been productive for some } \\
\text { economies, unproductive and even damaging for others where it } \\
\text { has negatively influenced the social income and welfare (Rocha, }\end{array}$ \\
\hline
\end{tabular}




\begin{tabular}{|l|l|}
\hline & 2012). \\
\hline $\begin{array}{l}\text { Mark Casson, } \\
1995\end{array}$ & $\begin{array}{l}\text { 'Judgmental decision-making is the defining characteristics of } \\
\text { Entrepreneurs (Casson, 2004). }\end{array}$ \\
\hline $\begin{array}{l}\text { Young Back Choi, } \\
1993\end{array}$ & $\begin{array}{l}\text { Entrepreneur is a deviant as s/he does not take knowledge for } \\
\text { granted and may find things significant which conventionalists do } \\
\text { not pay heed to. In this manner Entrepreneur may discover (Yu, } \\
\text { 2001). }\end{array}$ \\
\hline D.H.Harper, 1996 & $\begin{array}{l}\text { Entrepreneurship is Profit seeking activity which identifies and } \\
\text { solves loosely specified crisis, uncertain and complex situations } \\
\text { (Cherukara \& Manalel, 2011). }\end{array}$ \\
\hline
\end{tabular}

Source - Primary

\subsubsection{Sociological Theories of Entrepreneurship}

As per Ahwireng-Obeng (2006) the various thinkers in this field of study have sought to identify the transformation of human agents and the socio-economic setting in which they operate by examining the role of former and ongoing politics, social and economic institutions and their affiliation with ones values, motivations and incentives and their impact on the role entrepreneur plays in the society (Luiz, 2010). The contributors in this field of study are as shown in Table 1.5 -

TABLE 1.5

Sociological Theories of Entrepreneurship

\begin{tabular}{|l|l|}
\hline \multicolumn{1}{|c|}{ Authors } & \multicolumn{1}{c|}{ Theoretical Crux } \\
\hline $\begin{array}{l}\text { Gustav von Schmoller, } \\
1901\end{array}$ & $\begin{array}{l}\text { Entrepreneurship is individual initiative and risk-bearing under } \\
\text { private law as constitutive attributes as the head of the enterprise. } \\
\text { (Ebner, 2005) }\end{array}$ \\
\hline Max Weber, 1904-06 & $\begin{array}{l}\text { The economic agent in entrepreneurship is greatly influenced by } \\
\text { the 'Protestant Ethic' (Berger, 1991) }\end{array}$ \\
\hline Leland Jenks, 1944 & $\begin{array}{l}\text { Furthering the concept of 'Innovator' put forth by Schumpeter, } \\
\text { Jenks declares 'The Innovator is a person whose traits are in } \\
\text { some part a function of his socio-cultural environment. His } \\
\text { innovation is a new combination of factors and elements already } \\
\text { accessible'. (Jones and Wadhwani, 2006) }\end{array}$ \\
\hline \multicolumn{1}{|c|}{ Social Marginality } \\
\hline Sombart, 1911 & $\begin{array}{l}\text { Entrepreneur can be described as an agent concerned with the } \\
\text { uncompromising realization of imagined tasks and duties, subject } \\
\text { to long-run engagement (Ebner, 2005); creativity and the ability } \\
\text { to separate social values linked with entrepreneurship is more } \\
\text { recurrent among marginal and minority group. Non acceptance in } \\
\text { societies in which they live, enables individuals, to avoid } \\
\text { traditional values, and norms, that regulate economic behavior. } \\
\text { (Cherukara \& Manalel, 2011). }\end{array}$ \\
\hline
\end{tabular}




\begin{tabular}{|c|c|}
\hline \multicolumn{2}{|r|}{ Evolutionary Approach } \\
\hline $\begin{array}{l}\text { M.T.Hannan and J.H. } \\
\text { Freeman, } 1977\end{array}$ & $\begin{array}{l}\text { Theorized 'Population Ecology'; Believed upon integrating the } \\
\text { outcome of entrepreneurship, process and the social context } \\
\text { where entrepreneurship is existing. (Cherukara \& Manalel, } \\
\text { 2011). }\end{array}$ \\
\hline Patricia Thronton, 1999 & $\begin{array}{l}\text { Entrepreneurship is the formation of organization de novo which } \\
\text { is occurs as a context-dependent, social and economic process. } \\
\text { (Cherukara \& Manalel, 2011). }\end{array}$ \\
\hline Eric Stam, 2002 & $\begin{array}{l}\text { Defined entrepreneur as individuals who within specific social } \\
\text { and physical scenario, living at certain concrete time and spaces. } \\
\text { (Cherukara \& Manalel, 2011). }\end{array}$ \\
\hline
\end{tabular}

Source - Primary

\subsubsection{Psychological Theories of Entrepreneurship}

Psychological theories of entrepreneurship enable us to understand entrepreneurship with the application of personality based concepts. The justification of associating these two fields of study is underlying in (Frese, 2009) -

i. Evidences which reiterates that personality may play a crucial part in shaping entrepreneurship out of which main is meta-analytical evidence that highlights the importance of personality traits

ii. The research conducted by different researchers to divulge the personality traits effecting entrepreneurship

iii. The various studies in psychology started revealing variables other than personality traits which seemed applicable in different fields of study.

iv. The breakthrough advances in psychology as a domain of study worked as magnet for entrepreneurship to be studied from psychological viewpoint.

There have been numerous thoughts presented in this field of study by various thinkers which have been represented in form of following Table 1.6. 
TABLE1.6

Psychological Theories of Entrepreneurship

\begin{tabular}{|c|c|}
\hline Authors & Theoretical Crux \\
\hline $\begin{array}{l}\text { David C } \\
\text { McClleland, } 1961\end{array}$ & $\begin{array}{l}\text { 'Entrepreneurial conduct is determined by the need for personal } \\
\text { achievement leading to a penchant for becoming an entrepreneur'. } \\
\text { (UNCTAD, 2005) }\end{array}$ \\
\hline Hagen, E.E., 1962 & $\begin{array}{l}\text { Entrepreneurial conduct in an individual is the result of being } \\
\text { alienated from the society which drives them to assert themselves by } \\
\text { enterprise (Hamilton and Harper, 1994). }\end{array}$ \\
\hline Rotter J.B & $\begin{array}{l}\text { Locus of Control; An internal locus of control should lead to higher } \\
\text { entrepreneurial performance as there is need of great inner self- } \\
\text { motivation. (Frese,2009) }\end{array}$ \\
\hline B.S.Gilad, 1982 & $\begin{array}{l}\text { Furthering Rotter's viewpoint Gilad concludes that an individual's } \\
\text { locus of control plays a crucial role in determining his/her level of } \\
\text { entrepreneurial alertness which affects the entrepreneurial behavior } \\
\text { accordingly. (Hamilton and Harper, 1994) }\end{array}$ \\
\hline $\begin{array}{l}\text { Kets de Vries, } \\
1977 ; 2009\end{array}$ & $\begin{array}{l}\text { Psychodynamic Model; An in-depth study of Entrepreneur as } \\
\text { personality leads Kets de Vries to mention these six main } \\
\text { psychological themes - a need for control, a sense for distrust, a } \\
\text { desire for applause, a tendency to 'split', scapegoating and the flight } \\
\text { into action. (Ostergaard, 2014) }\end{array}$ \\
\hline \multicolumn{2}{|r|}{ Situational Approach } \\
\hline Glade W. P. 1967 & $\begin{array}{l}\text { It holds that an 'Opportunity Structure', an 'Objective Structure' of an } \\
\text { economic structure and a structure of differential advantages in the } \\
\text { capacity of the systems participant to perceive and act upon such } \\
\text { opportunities. (Thronton, 1999) }\end{array}$ \\
\hline $\begin{array}{l}\text { Greenfield S. M. and } \\
\text { Stickon A., } 1981\end{array}$ & $\begin{array}{l}\text { Entrepreneurial Mechanism can bring paradigm shift to a society; } \\
\text { Entrepreneurs reflects unique characteristics like risk appetite, } \\
\text { alertness to new opportunities, creativity capacity to convert them into } \\
\text { commercial entity. (Vu, Napiar and Hoang, 2012) }\end{array}$ \\
\hline Gartner, W. B. 1985 & $\begin{array}{l}\text { There are no as diversified personality difference between } \\
\text { entrepreneur and non-entrepreneur than entrepreneur w.r.t other } \\
\text { entrepreneur; Owners/Managers are highly heterogeneous group; } \\
\text { Descriptive and behavioral definition of Entrepreneurship can be - } \\
\text { Entrepreneurship is the creation of new organization. (Rauch \& Frese, } \\
\text { 2000) }\end{array}$ \\
\hline \multicolumn{2}{|r|}{ Social Constructionism } \\
\hline $\begin{array}{l}\text { Elizabeth Chell, } \\
\text { 2000; } 1985\end{array}$ & $\begin{array}{l}\text { Entrepreneurs are well networked; In case of Entrepreneurship, } \\
\text { behavior is the function of personality and situation, and their } \\
\text { interaction (Chell, 2008). }\end{array}$ \\
\hline
\end{tabular}




\subsection{Types of Entrepreneurs}

Many authors have attempted to classify entrepreneurs and small business owners on ground of thereby established typologies and taxonomies (Filion, 1998). Filion further presents few important typologies as propounded by various authors as shown in Table. 1.7.

TABLE 1.7

Typologies of Entrepreneurs

\begin{tabular}{|c|c|c|}
\hline Authors & Date & Typology \\
\hline $\begin{array}{l}\text { Collins, Moore et al. } \\
\text { Collins and Moore }\end{array}$ & $\begin{array}{l}1964 \\
1970\end{array}$ & $\begin{array}{l}\text { Two types of entrepreneurs: } \\
\text { 1. The administrative entrepreneur } \\
\text { 2. The independent entrepreneur }\end{array}$ \\
\hline Smith & 1967 & $\begin{array}{l}\text { Two types of entrepreneurs: } \\
\text { 1. Craftsman } \\
\text { 2. Opportunist or business entrepreneur }\end{array}$ \\
\hline Laufer & 1974 & $\begin{array}{l}\text { Four types of entrepreneurs: } \\
\text { 1. Manager or innovator } \\
\text { 2. Growth-oriented owner-entrepreneur } \\
\text { 3. Entrepreneur who refuses growth but seeks efficiency } \\
\text { 4. Artisan entrepreneur }\end{array}$ \\
\hline Vesper & 1980 & $\begin{array}{l}\text { At least } 11 \text { types of entrepreneurs: } \\
\text { 1. The self-employed working alone } \\
\text { 2. Team builders } \\
\text { 3. Independent innovators } \\
\text { 4. Multipliers of existing models } \\
\text { 5. Exploiters of economies of scale } \\
\text { 6. Capital gatherers } \\
\text { 7. Acquirers } \\
\text { 8. Artists who buy and sell } \\
\text { 9. Conglomerate builders } \\
\text { 10. Speculators } \\
\text { 11. Manipulators of apparent values }\end{array}$ \\
\hline $\begin{array}{l}\text { Julien and } \\
\text { Marchesnay }\end{array}$ & $\begin{array}{l}1987 \\
1998\end{array}$ & $\begin{array}{l}\text { Two types of owner-managers: } \\
\text { 1. PIG (perpetuation, independence, growth) } \\
\text { 2. GAP (growth, autonomy, perpetuation) }\end{array}$ \\
\hline Lafuente and Salas & 1989 & $\begin{array}{l}\text { Four main types of new entrepreneurs in Spain, based on } \\
\text { entrepreneurial aspirations: } \\
\text { 1. Craft } \\
\text { 2. Risk-oriented } \\
\text { 3. Family-oriented } \\
\text { 4. Managerial }\end{array}$ \\
\hline Hornaday & 1990 & $\begin{array}{l}\text { Three types of entrepreneurs: } \\
\text { 1. Craft }\end{array}$ \\
\hline
\end{tabular}




\begin{tabular}{|c|c|c|}
\hline & & $\begin{array}{l}\text { 2. Promoter } \\
\text { 3. Professional manager }\end{array}$ \\
\hline $\begin{array}{l}\text { Miner (following } \\
\text { work by Miner, } \\
\text { Smith et al.) }\end{array}$ & $\begin{array}{l}1990 \\
(1989)\end{array}$ & $\begin{array}{l}\text { Three types of entrepreneurs: } \\
\text { 1. Entrepreneur } \\
\text { 2. Growth-focused entrepreneur } \\
\text { 3. Manager }\end{array}$ \\
\hline Filion & $\begin{array}{l}1994, \\
1996\end{array}$ & $\begin{array}{l}\text { Two types of entrepreneurs: } \\
\text { 1. Operator } \\
\text { 2. Visionary }\end{array}$ \\
\hline Siu & 1995 & $\begin{array}{l}\text { Five types of owner-managers in China: } \\
\text { 1. Senior Citizen } \\
\text { 2. Workaholic } \\
\text { 3. Swinger } \\
\text { 4. Idealist } \\
\text { 5. Hi-Flyer }\end{array}$ \\
\hline
\end{tabular}

Source-Filion, 1998

Given the fair understanding of typologies put forth by respective authors Filion also highlights that no one classification suffice covering complete types of entrepreneurs (Filion, 1998). But these classification become foundation for the researchers to conduct their research and explore the similarity and deviation of their set of sample entrepreneurs from the abovementioned and other typologies.

Advancing from discussion of entrepreneurial typologies to the discussion of entrepreneurial practices it may be stated the entrepreneurship in India has faced many era's. A renewed effort to document, comprehend and assimilate business history of India becomes a pressing need and a meaningful endeavor to advance this study. In next section let us discuss in much detail the evolution of entrepreneurial DNA in India.

\subsection{Entrepreneurship in India}

Many research papers and book authors have written about the entrepreneurial DNA of India. In fact, Indian diaspora is considered to be one of the most successful entrepreneurs around the world (PWC, 2014).India has history of entrepreneurship in its very origin. Economists like Adam Smith and Max Weber (as cited by Audrestch \& Meyer, 2009) emphasized that economic conditions of a nation are greatly determined 
by the religious beliefs According to Audretsch \& Meyer (2009) in India there exist interesting relationship between the religious culture and economic behavior. Main religions in India are Hinduism, Buddhism, Sikhism, Islam, Christainity and Jainism. Hinduism is dominated by varna system which shapes individuals values and beliefs. . While presenting his views about Hindu education in about 1000 A.D Al-Beruni remarked Hindu people were ignorant about the art and culture of west as they mostly remained detached from the outer world which continued for 800 years (Tripathi, 1971). The educational system propagated the occupational system related to the caste system. Ancient scriptures presents the existence of 4 main varna's in India - Brahminwho were traditionally involved in religious activities like performing rituals etc in temples and rite of passage rituals like solemnizing a wedding with hymns and prayers etc, Kshatriyas were monarch or the king involved in the protection of land which was ruled by them, Vaishiyas were mainly cattle herders, agriculturists, artisans and merchants i.e. mainly traders and businessman, lastly shudra which was mainly involved in serving the other three vernas. Initially the occupation of the person represented their caste which gradually started passing on to the future generations (Audrestch \& Meyer, 2009). Hence from centuries Indian economy has been greatly affected by the occupational choices people made based on their varna's. Al-Beruni as cited by Tripathy, has also remarked that business was considered to be low esteemed profession (Tripathy, 1971). According to Kautilya, businessman was a thief, and this view was seen permeated in Indian society for coming many years (Tripathy, 1971). In 1950 the varna system of caste stratification was abolished by Indian government and since then choice of occupation no longer depends upon the ancestral origin of person (Audrestch \& Meyer, 2009).

\subsubsection{Pre Colonial India before 1757}

In the pre-colonial era Indian Trade and business were at its peak. Techniques like smelting of brass and tin were mastered by Indians. Kanishka Empire is believed to be nurturing Indian entrepreneurs and traders. Following this period is the period which is marked on increasing business ties of Indian traders with Roman empires (Pahurkar, 2011). This period also faced the ingress of Portuguese and English traders and experienced the beginning of European Commercial Enterprise at around 1600 in India. 
Due to European Commercial Enterprises (East India Company being the main) this period gained India more profit over Europeans or exploits of East India Company as the demand for Indian goods was more in Europe and English nations and their exploits than demand for their goods by Indians. This kept balance of trade always inclined in favor of India. Due to the fact that Indian economy is in profit more than their countries, government of both the countries made regular amendments in their trade regulation to restrict the usage of Indian product in respective countries. But according to the little knowledge available, it can be stated that there was net gain to Indian economy at least till 1757 when British occupied a part of Bengal. This profit to the Indian economy was majorly enjoyed by mercantile class of Indian Society which utilized this profit for their traditional activities like trade and money lending. For this era the European travelers have testified that these mercantile class like Vora's in Gujarat, Seths of Eastern part of India (who flourished in the early half of $18^{\text {th }}$ Century) and Malya's of Tamil Nadu were very clever in their business sagacity and possessed business sense no less than their western counterparts. It was clear in this era that their business practices were away from any religious beliefs and were to satisfy their personal needs. Hence there was no substantial constructive development in the way businesses were done. Easterbrook's concept of the 'Climate of Enterprise' was observed flourishing in Indian environment in this era which was more dominated by material environment over spiritual and religious environment.

\subsubsection{Colonial India (1757-1947)-}

This era earmarked the development of many new businesses introduced by East India Company and Parsi's in India (Tripathy, 1971).

- Tea Plantation - East India Company started Tea Plantation in around 1830's in Assam Hills with an intention to hand over the plantation business to private enterprises. In 1837, the company was ready to hand over the business to private Bengali players but Bengali businessmen were hesitant to take advantage of this opportunity.

- Coffee Plantation and Jute Plantation like tea plantation was entirely introduced by East India Company. 
- Established businesses of Leather Manufacturing

- They hugely invested in exploitation of untapped natural resources as products like in indigo plantation, coal mining and made an unsuccessful attempt to establish their business in steel manufacturing in India

Cotton Textiles and Steel manufacturing were to such industries which did not attract the British, and probably because of this Indian entrepreneurial interest was prominently visible in these industries. It's worth mentioning that first cotton textile mill was established in 1851 by a Parsee, Cowajee Nanabhoy Davar (Tripathy, 1971) and J.N. Tata again a Parsee from 1868 to 1904 kept venturing into number of businesses from a trading firm in 1868, to a world class hotel, The Taj Mahal Palace Hotel in 1903. In between he as a fervent entrepreneur kept venturing into number of businesses like in 1869 he bought a bankrupt oil mill and converted it into cotton textile mill and then sold it on profit after two years, he again started a cotton mill at Nagpur in 1874 which he name Empress Mill after the name of Queen Victoria who was proclaimed empress of India on $1^{\text {st }}$ January, 1877 (Tata Central Archives, Circa 1900). Jamsetji Nusserwanji Tata, who is considered to be the legendary 'Father of Indian Industry', was more than an entrepreneur who by his vision elevated India to claim a position on global arena of industrialized nations. He was ignited with immense sense of nationalism and zeal to advance the economic status of India from its current standing. At a time when few business legendaries like Andrew Carnegie, J.P. Morgan and J.D. Rockefeller of his western counterpart were busy developing their business empire by disobeying laws and exploiting labor force in late 1800s, Jamshedji was exploring measures in welfare of his labor force and also became a salaried Managing Director who was reporting to a functional board of directors, a practice which was worldwide introduced in 'Corporate Governance Framework’ much later (Gopalakrishnan, 2014).

Thereby this era provided many innovative and unexploited business opportunities to those who wanted to explore their entrepreneurial skillfulness. Also, according to Tripathy, 1971 in his paper 'Indian Entrepreneurship in Historical Perspective' in EPW its pointed that during this period British Empire and Parsee industrialists introduced many business opportunities to Indian market and provided a platform to Indians to introduce to them latest high end technologies, assuring them personnel who are well trained in using these technologies and groomed them on various corporate management skills. 
The writing of Raj K Shankar argues, although British Empire brought in India long awaited administration and organized infrastructures but it is equally true that their ruling pushed Indian businesses towards extinction (Shankar, 2009). Shankar's writing disseminates, in the strict ruling of British Empire which almost made India a sourcing geography for their business empires, imposed one way trade from of Britain to India and imposed high taxes on Indians in nearly all forms of trade and productions which snatched India's tag of being rich and self reliant. In this period Indian entrepreneurial spirit was persistent by the efforts of business eminent like A.D Shroff, John Mathai, Lala Shri Ram, Kasturbhai Lal Bhai, Purshotamdas Thakurdas, Birla and Tata, who kept developing their empires even in the adverse regime of British ruling. It is also believed that they worked coherently in 1944 towards 'Bombay Plan' to bring rapid industrialization in India and to achieve self reliance. But how one could expect this dream to flourish in British regime? Hence these entrepreneurs seemed extending financial assistance to freedom fighters. G.D Birla is believed to be one such entrepreneur who provided financial aid to Mahatma Gandhi for the national cause of freedom from planned colonization of British Empire.

\subsubsection{Post Independence ( 1947 onwards)-}

The India which was taken over by Nehru was full of diverse set of people in terms of religion, language, economical status and interests. Nehruvian Era focused prominently on ensuring stability, establishing governance and creating jobs (Shankar, 2009). The work of Tabe and Gariappa (2013) in their book 'Entrepreneurship Development in India - Emergence from Local to Global Business Leadership' gives a fairly clear gist of how did entrepreneurship grow in India post independence. Book reveals that post independence India was exploring models for economic development and finally zeroed on Mahalanobis Model.

- Mahalanobis Model divides Indian Economy into four major sectors (Komiya, 1959) Sector - 1 - Investment goods industries, Sector -2 - Factory organized, consumers' goods industries, 
Sector - 3- Small Scale, house-hold industries consumers' goods

3-1 - Agriculture

3-2 - House-hold or handicraft industry

Sector - 4-Service industries, including health, education and so on.

- This model proposed to development of investment goods industries sector like investment in mining and production of capital goods, infrastructural development including electricity generation and transportation over the development of service and household goods sector.

- Model paid less attention to invest on factory goods sector based on the belief that it is capital intensive and wouldn't serve the problem of massive unemployment.

- Investment activities were proposed to be done both by Government and private sectors. Government made investments in strategic sectors like in national defense and in sectors where size of investment was that huge that private sector could not invest in these sectors like in infrastructure. Government planners would decide the sectors in which private sector was required to make investments for the India's economic growth. In nutshell, Government not only did start determining activities/sectors in which private sectors should be investing but government also started making key decisions on production, selling of produces and prices of produces for private companies.

Shankar (2009) writes in his article 'The rise and rise of Indian Entrepreneurism', the time from 1965 to 1990 can be considered most challenging both from economic development and entrepreneurial state of affairs perspective. Government policies became more strict, rigid, bureaucratic and authoritarian which lead the downfall of industrial output from $7.7 \%$ to 4\% during 1966to 1980. 1969 was remarkable year as government introduced two more steps:-

- First was Nationalization Act which led to nationalization of banks and insurance companies. Article 'Nationalization of Banks in India - The Economic Effect' in UK Essays underlines that the motive of nationalization was to own the means of production, distribution and exchange by state thereby to effect the rational allocation of output, consolidation of resources and rational planning of the economy. By this government intended to exercise full control over means of production thereby ensuring equal distribution of output for the benefit of public at large (UK Essay, 2015).

- Second step was implementation of Monopolies and Restrictive Trade Practices Act (MRTP Act) which accorded the debarring of business expansion of businesses with 
turnover over Rs. 20 crore. Due to this reason over 100 proposals of Tata with regard to business expansion of existing businesses were rejected. This proved deterrent to entrepreneurial wave of the post independence economic scenario (Shankar, 2009).

When India lacked business opportunities, youth started identifying opportunities beyond the national border giving rise to infamous phenomenon 'The Brain Drain'. During this period few prominent Indian Entrepreneurial names included Sabhir Bhatia, Lakshmi Mittal, Vinod Khosla etc whose efforts achieved colossal success in foreign land against their Indian counterparts. Back in India, business entrepreneurs were still looking for opportunities to knock their doors (Shankar, 2009).

In nutshell it should be understood that in this era towards 1970s Indian market was infamous as most protected and heavily regulated economies in the world. Only in mid 1970s and then later in 1980s tentative steps were taken to liberalize the market (Kotwal, Ramaswami and Wadhwa, 2011).

\subsubsection{Post 1991 - Impact of Liberalization}

Post liberalization MSME sector in India experienced tremendous change. In his article Shankar (2009) gives a clear picture of scenario prior to 1991. Prior to 1991 when the economy was closed, protected and regulated by the federal government, it was difficult for a common man to envision business venture of his own. Business was very much restricted to rich and eclectic few like Tata's and Birla's. Then came few more names who dared to open up establishments in the strict regulations among whom the pioneering ones are Dhirubhai Ambani, Munjals and Rahul Bajaj.

In post liberalized era measures like systematic efforts to reduce license-raj marks the importance which led even the small investors to start up their entrepreneurial ventures. The greatest impact of liberalization was visible on the rising number of first generation entrepreneurs (Shankar, 2009). Many new form of businesses were being explored by these first generation entrepreneurs mainly in IT sector gradually giving rise to 'Knowledge Economy' (Goswami, Dalmia and Pradhan, 2008) . Government was 
vigilant on the industrial performance and its growth which had the potential to safeguard the sinking economy hence started adopting measures especially to encourage MSME sector for the welfare of the economy. It can be further supplemented by the submissions made by Ravi (2014) in his work 'What drives Entrepreneurship? Some Evidence from India'. In this work the growth of MSMEs has been captured from 1991 to 2006 by analyzing the panel data of 35 States and Union Territories. According to this paper, India witnessed steady growth in the number of MSMEs from 67.07 lakh in 1991 to 113.95 lakh in 2003 (Ravi, 2014).

\section{CHART 1.2}

\section{Growth of Indian Micro, Small and Medium Enterprises Sector (1990-2003)}

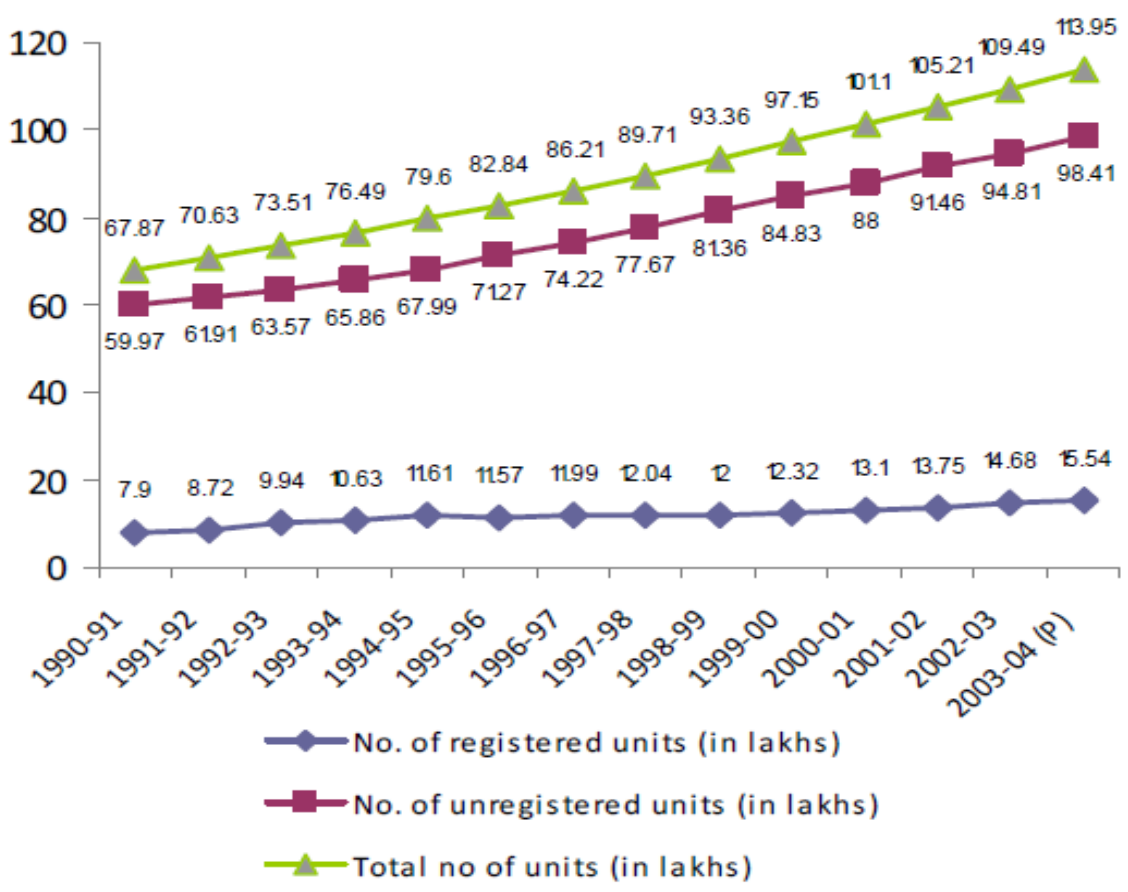

Source - Annual Survey of Industries, Ministry of Statistics and Program Implementa tion, GoI as cited by Ravi (2014)

Chart 1.2 also highlights an important point which cannot be overlooked. The rise in the number of unregistered enterprises outnumbers the numbers of registered enterprises. Therefore the crucial role played by unregistered firm is impossible to be overlooked. 
CHART 1.3

Comparing growth of SME sector to Industrial Output
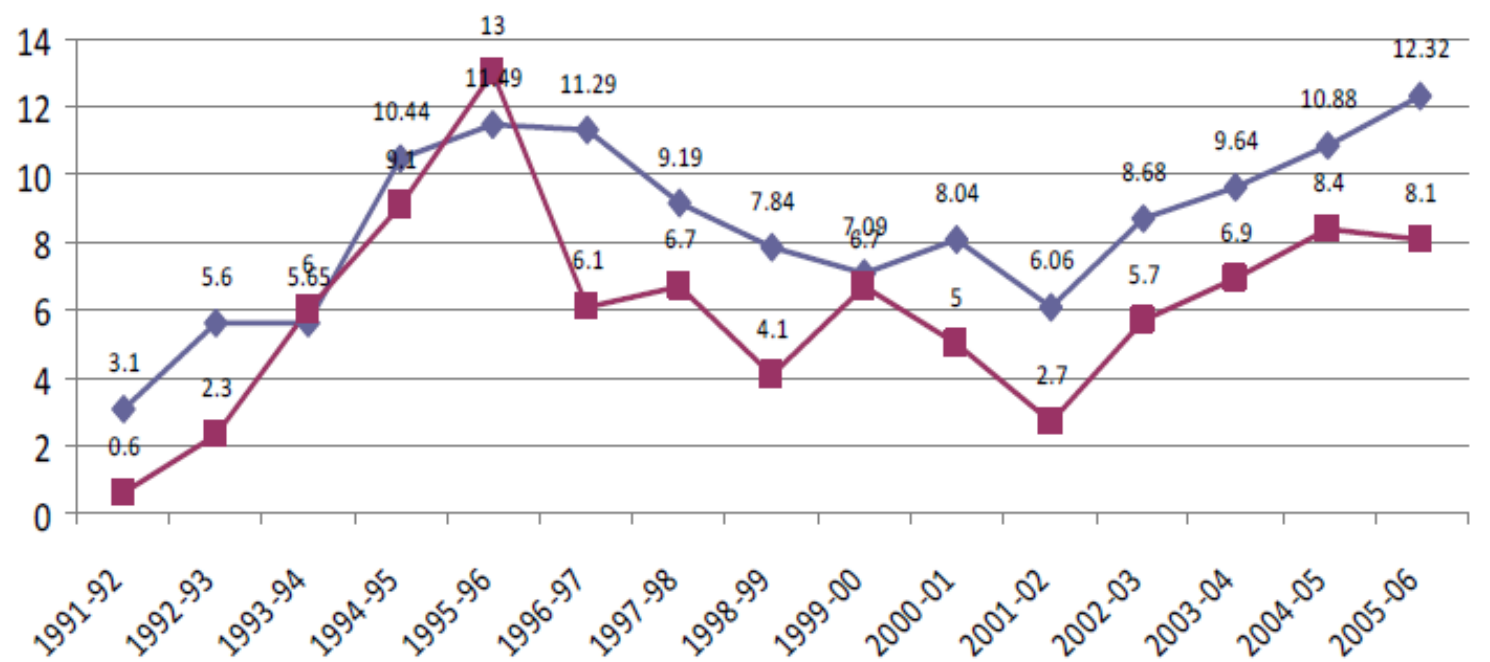

$\smile$ SME sector growth rate $\quad-$ Total Industrial sector growth rate

Source - Annual Survey of Industries, Ministry of Statistics and Program Implementa tion, GoI as cited by Ravi (2014)

On comparing the growth rate of SME sector with that of total industry for the period 1990 - 2000, it is revealed that the growth rate of SME sector is consistently higher than the total industrial growth rate especially after 2000 as shown in Chart1.3. On an average the growth rate of SME sector has been observed as impressive 8.47 per cent as against 6.1 per cent in case of total industrial growth rate (Ravi, 2014).

Some important policy changes for SME development during this period were (Ravi, 2014):-

- Targeted State policies for SME development -

a) State financial subsidy for MSME development

b) Establishments of industrial parks for MSME development

c) Cluster and park set up for MSME development

d) State expenditure support towards technology adoption for MSME up gradation

- General development policies affecting MSME and hence entrepreneurship were -

a) Investments on infrastructure which directly boosted opening of new entrepreneurial ventures. 
b) Increase in the number of bank branches which enhances the accessibility of finance to majority of public.

A regression analysis carried out in the study lead by Ravi (2014) to understand the effectiveness of above policy measures on the performance of the MSME sector divulges that most effective measures out of the above have been facilitating the enterprises with infrastructural facilities (like roadways, electricity, buildings, better connectivity etc) and extending the accessibility to finance by increasing the number of branches, setting up clusters and parks and assisting in technology upgradation (Ravi, 2014).

It can be concluded that government's role in this period have been effective mainly as facilitator and by creating an enabling environment entrepreneurial players.

\subsubsection{Post Recession (2008 onwards)}

In the recent past India again faced major economic setback due to the backdrop of interconnectivity of financial markets across the globe. It started in U.S financial market due to three major reasons (Secretariat, 2009)-

- Sub-prime Mortgages

- Securitization and Repackaging of Loans

- Excessive Leverage

The entwined global economy especially the over dependency of world economy on U.S. market led the fall of economies in developed as well as in developing countries.

In this context the then Prime Minister of India, Shri Manmohan Singh recognized this as a crisis in following words (PM in G-20 Summit as cited by Secretariat, 2009) -

"..It is a time of exceptional difficulty for the world economy. The financial crisis, which a year ago, seemed to be localized in one part of financial system in the U.S., has exploded into a systematic crisis, spreading through the highly interconnected financial markets of industrialized countries, and has had its effects on other markets also. It has choked normal credit channels, triggered a world-wide collapse in stock markets around 
the world. The real economy is clearly affected. ... Many have called it the most serious crisis since the Great Depression."

India experienced the effect although in lesser extent than other economies thanks to strong domestic demands, with growth falling to just 6.7 per cent in 2009 (Verick \& Islam, 2010). In terms of industrial performance following effects were visible-

a) Service sector which contributes to 50 per cent of share in GDP experienced decline especially in transports, communication, trade and hotel and restaurants sub-sector (Secretariat, 2009).

b) Manufacturing sector showed severe decline from 9.8 per cent in April-November, 2007 to 4.0 per cent in April-November 2008 (Secretariat, 2009).

c) Export market affected the export driven sectors like gem and jewelry industries, fabric and leather industries (Secretariat, 2009).

d) Federation of Indian Micro, Small and Medium Enterprises in December 2008 reported that nearly 4000 ancillary units are on the verge of shut down negatively affecting the livelihoods of about 200,000 people (UNCTAD, 2010).

e) A lot of industry took the path of either shut down or downsizing affecting the livelihood of masses of employed population like 50,000employees lost their jobs in engineering industries in Coimbatore, around 70,000 people lost their jobs in automobile industry as reported by Auto Components Manufacturers Association between September to December, 2008, and worst of all was the scenario of Diamond sector in Surat where nearly 2,00,000 people are estimated to have lost their jobs (UNCTAD, 2010).

Considering the importance of imperative role played by MSME sector for the overall augmentation of National Economy, Indian Prime Minister announced a task force on MSMEs on August, 2009 (PWC, 2011) under the Chairmanship of Principle Secretary Shri. T.K.A Nair. The task force identified six widespread problems under major thematic areas to be addressed as shown in Fig 1.2. 


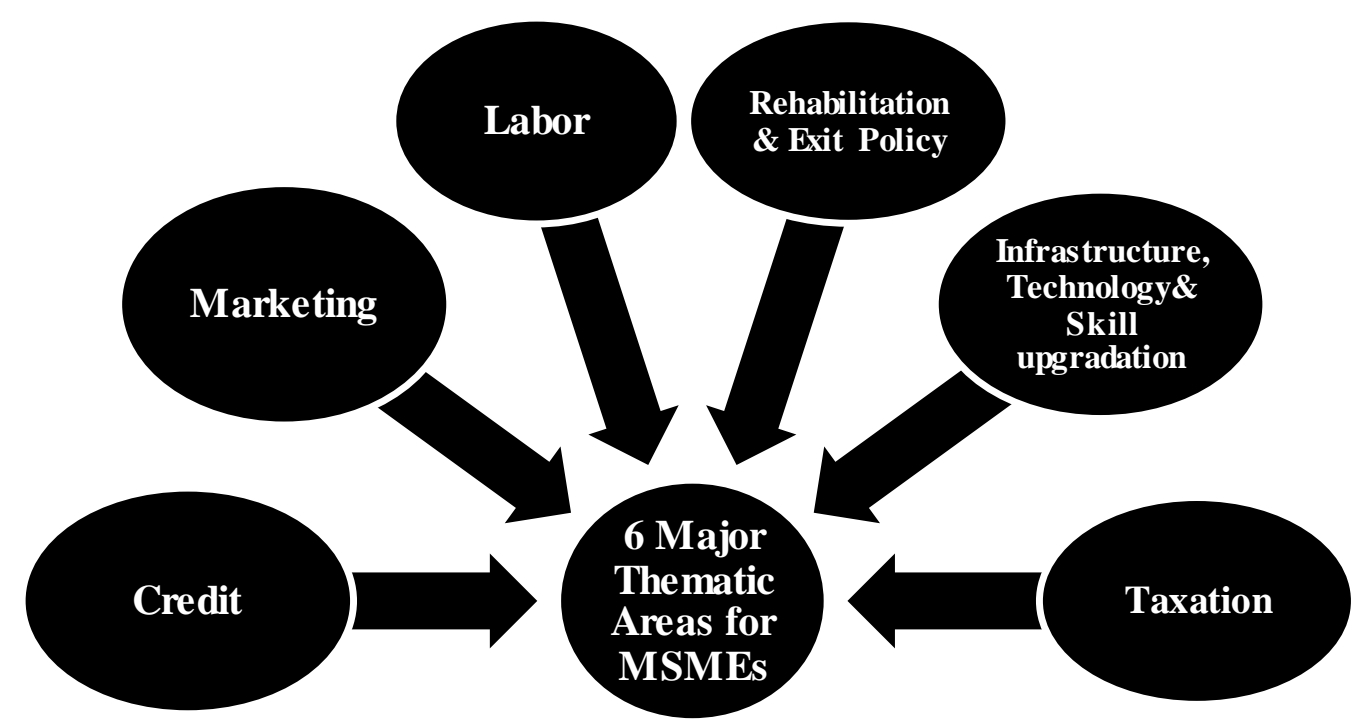

Source - Figure prepared by researcher on basis of information received from (PwC and CII, 2011)

FIG 1.2

Six Major Thematic Areas for MSMEs

Government started taking actions on the recommendations provided by the task force especially in the areas (MSME, 2010)

- Credit - easy and adequate credit facility like implementation of credit guarantee scheme, credit rating scheme and policy packages.

- Marketing - Government with the establishment of Department of Expenditure (DOE) and Chief Vigilance Commission (CVC) has proposed Public Procurement Policy which mandates the public bodies to procure 20 per cent of their purchases from MSMEs for a period of 3 years.

- Labor-Recognizing the transaction cost of Labor Laws in MSME sector is relatively higher recommendations like efforts to pass Labour Law Amendment Bill, Ministry of Labour and Employment should diligently examine ESIC and EPF Act and will utilize unclaimed Rs. 5000 crore lying with EPFO for the welfare of the workers etc.

- Rehabilitation and Exit Policy - Few important actions recommended for this issue includes, first, appeal to MSME owners to convert into Limited Liability Partnership Act, 2008 or One Person Company as introduced under Companies Bill, 2009 to reduce the registration and transaction cost and second, introduction of model insolvency act which enables the speedy exit of unincorporated enterprises etc. 
- Taxation - Various measures in consultation with Department of Revenue was recommended to be implemented for the tax relaxation and upgrading the limit of tax exemption from Rs. 40 lakh to Rs. 1 crore etc.

- Infrastructure/Technology/Skill Development/Institutional Structures:- Expansion of scope of existing Integrated Infrastructural Development (IID) Scheme, provision of 60 per cent of land in ongoing industrial park for MSMEs, setting up of common estates/clusters on PPP mode in the ongoing schemes of various ministries, earmarking of at least one industrial estate for MSME sector, initiatives taken under the National Manufacturing Competitiveness Programme (NMCP) by MSME ministry for the upgradation of the technology, establishment of 'Technology Banks' which will be mainly engaged in developing technologies for the MSME sector, CAPART to play its role for innovations and advancements in rural areas, oath to train 500 million people by 2022, linkages to strengthen between industry and skill development agencies, involvement of Panchayati Raj Institutions to impart training to artisans of the villages, and many such scheme were recommended to be implemented.

According to the Annual Report-2012-2013 many of the above recommendations have been achieved and ongoing recommendations are being monitored periodically.

In nutshell by 2012 Indian economy was relatively stable and had started taking pace to achieve new heights in terms of performance in growth front. Government was taking every possible step to ensure the speedy recovery of hit economy by the waves of economic recession. Steps like supporting the growth of MSMEs through establishment and development of industrial clusters, industry-focused investment regions, implementing reforms in thematic areas, promotion and spreading out of MSMEs adopting innovative initiatives and launch of cluster development measures to support and reinforce the augmentation of the sector (CII, 2010). Many promising industries were recognized and the target groups were given skill development training in Food and Agro Sectors, Biotech and Pharma Sector, Defense and Homeland Security (within the supply chain of defense and aerospace which is further motivated by the 100 per cent opening of Defense Sector for Indian private sector participation subject to licensing), Cleantech or Green Technologies etc (PWC and CII, 2011) 


\subsection{Women Entrepreneurship in India}

Historically there has been radical shift in the role women especially when it comes to Indian society. The evolution of role women has played can be comprehended in Fig 1.3.

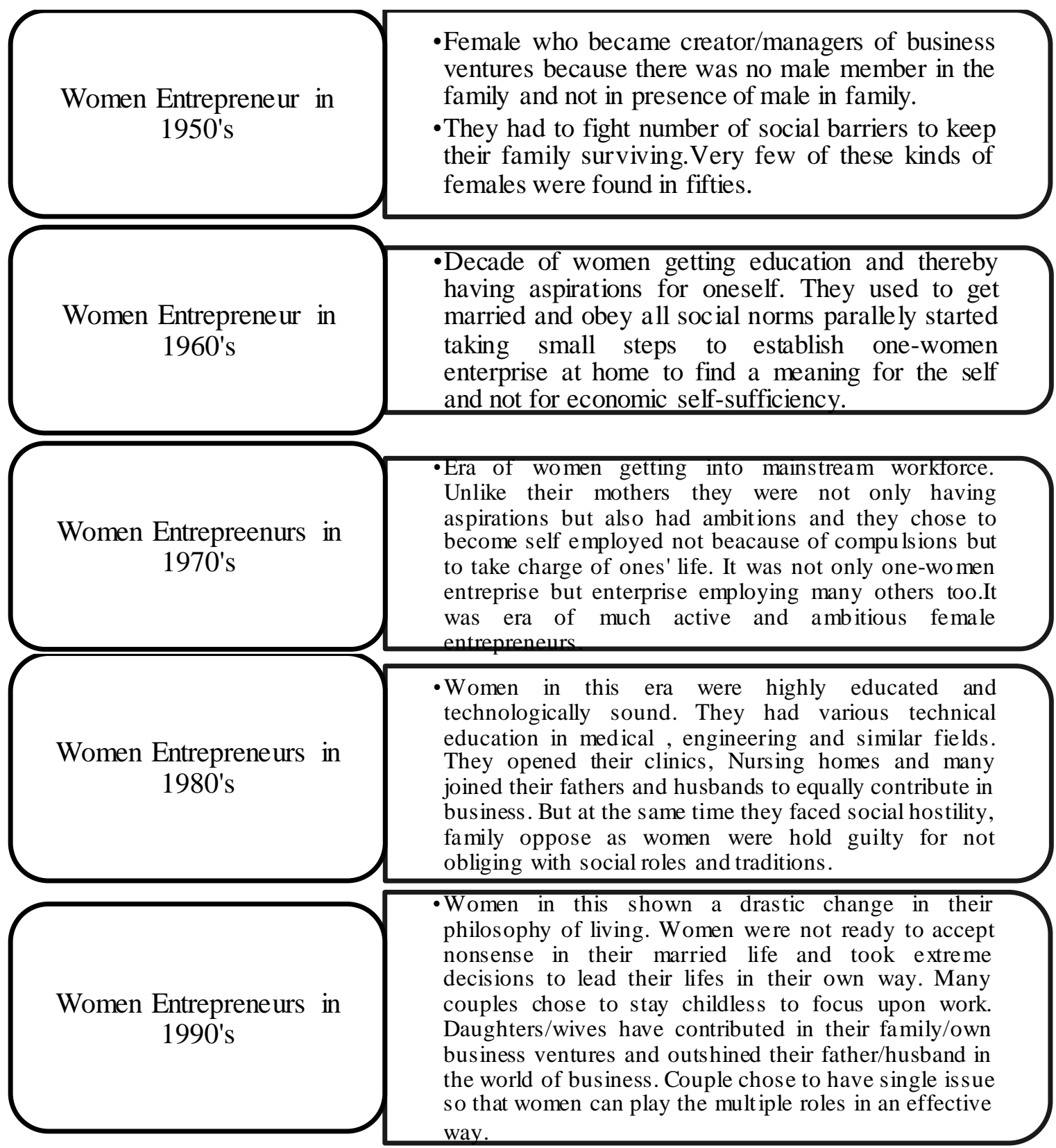

Source - "A reflection of Indian Women in Entrepreneurial World", Working Paper (Research and Publication, IIM-A, India) W.P. No. 2005-08-07, August 2005, Pg. 12

FIG 1.3

Process of growth in Social Status of Women Entrepreneurs in Indian Society 
A brief history of commencement of women entrepreneurship in India has also been documented in Gujarat - MSME Report, 2013. According to it women entrepreneurship in India initially started as part of community enterprises which at the inception was a social programme of community development and women empowerment. The Community Development Programme of 1950s and Women's Co-operative Movement of 1960s were the basis for women to come together in groups who later indulged into economic activities. Such organizational initiatives became a tool in the hands of federal and state governments for poverty reduction in the 1990s. Government started encouraging women establishments by State-sponsored poverty reduction mission which steadily merged with larger stream of national micro-finance movement. Although number of such initiatives were encouraged but it is difficult to track that how many of such organizational initiative were added to the ecosystem of Indian Businesses. Kudumbashree in Kerala and the Madhya Pradesh Rural Livelihood Projects were few widespread state-sponsored projects which can be named (Gujarat - MSME Report, 2013).

The struggle made by women section of the society is not hidden. Fig.6. depicts the firm steps women have taken in different eras to step out in the society for carving a niche for them. In the ongoing economy some statistics pertaining to MSME and women's participation in MSME is facilitated by $4^{\text {th }}$ All India Census of MSME as reported by Annual Report on MSME 2014-15 as shown in the given Table1.8:-

TABLE 1.8

Women Enterprises in MSME sector in the India

\begin{tabular}{|c|c|c|c|c|c|}
\hline S.No. & Characteristics & $\begin{array}{l}\text { Registered } \\
\text { Sector }\end{array}$ & $\begin{array}{l}\text { Unregistered } \\
\text { Sector }\end{array}$ & EC-2005* & Total \\
\hline 1 & $\begin{array}{l}\text { Size of Sector (in } \\
\text { lakh) }\end{array}$ & 15.64 & 198.74 & 147.38 & 361.76 \\
\hline 2 & $\begin{array}{l}\text { No. of Women } \\
\text { Enterprises (in } \\
\text { lakh) }\end{array}$ & $\begin{array}{c}2.15 \\
(13.72 \%)\end{array}$ & $\begin{array}{c}18.06 \\
(9.09 \%)\end{array}$ & $\begin{array}{l}6.40 \\
(4.34 \%)\end{array}$ & $\begin{array}{l}26.61 \\
(7.36 \%)\end{array}$ \\
\hline
\end{tabular}

* Economic Census - 2005

Source-Annual Report, 2014-15

The table is evidently illustrating the less participation women shows (7.36 per cent of total) in start-up businesses. Statistically GEM studies are consistently depicting less 
participation of women than men the start-up businesses regardless of the national context Allen et al., as cited by Alsos, Jensen \& Ljunggren (2010). In their article 'Gender and Entrepreneurship' (Alsos, Jensen and Ljunggren, 2010) the phenomenon of entrepreneurship has been greatly acknowledged as 'Gendered'. In 1980s the wave of studies on gender and entrepreneurship erupted. These studies exposed the gender imbalance existing in entrepreneurship and also revealed important characteristics of men and women entrepreneurs. But these studies failed to unveil the reasons behind the imbalance (Alsos, Jensen and Ljunggren, 2010).

In recent times many studies have been thriving in grabbing the nerves of this phenomenon. GEM 2012 Women's Report, a study of 67 economies conducted by GEM in 2012, highlights few important attitudes and context factors associated with women entrepreneurship in the given economies as (GEM, 2012):-

i. Societal perceptions of opportunities in the environment-It intends to identify the societal perception on - whether or not enough opportunities are available in market for women to project their entrepreneurial skill? Developed Asia is believed to have lowest average perception i.e. mere 19 per cent of opportunity for women entrepreneurs relative to other economies like Sub-Saharan African and Latin America/Caribbean (69 per cent) and developing Europe (26 per cent).

ii. Self assessment about capabilities and fear of failure - In every economy a general notion avails of men are more capable over women. 73 per cent of Sub-Saharan African women are with highest average level of perceived capabilities while not majority of women in Developed Asia (only 16 per cent) have perceived capabilities in self. Fear of failure is observed by 47 per cent of women in Developed Asia against 25 per cent of sub-Saharan African women, 31 per cent of Latin American/Caribbean women, 52 per cent of Israel women among the others.

iii. Necessity versus opportunity motives-Entrepreneurship can prevail in backdrop of unavailability of any other mode of income generation i.e. necessity based or it can be out of an intense aspiration to chase an opportunity. In Mid Asia there quite substantial women entrepreneurs i.e. 36 per cent, who fall in the former class of necessity based entrepreneurship against 37 per cent in Sub-Saharan an MENA. Developed Europe unveils highest number of opportunity based i.e. 73 per cent women entrepreneurs. 
An International Finance Corporation (IFC) Report on 'MSME Finance - Improving finance to women-owned businesses in India' (2014)underscores the constraints on demand side and supply side of access of finance for women entrepreneurs (IFC, 2014) -

a) Demand side constraints - It includes hurdles like insufficient financial knowledge and knowledge of financial products, lack of collateral security, inappropriate support from male members of the family and lack of confidence to approach the financial institutions.

b) Supply side constraints - Here the perception of women becomes constraint on the supply of women entrepreneurs to the economy. The widespread perceptions playing imperative role of constraints are perception of higher risk profile in absence of collateral security or guarantee by male members of the family, tedious documentation and procedural requirements (in case of women many documents are even unavailable), negative / unwelcoming attitude of bank officials towards women entrepreneurs, high transaction costs of administering the loan procedures irrespective of size of the venture is troublesome, lack of nitty-gritty's of financial management makes and in presence of fraudster cases in the market women entrepreneurs are less attracted towards the financial institutions.

The Gender Global Entrepreneurship and Development Index-2014 (Gender-GEDI), a 30 country analysis of the conditions that foster high potential female entrepreneurship, here on basis of Gender-GEDI Index score is awarded to the nation studied basically measuring three main sub-indices - Entrepreneurial Environment, Entrepreneurial Ecosystem and Entrepreneurial aspirations. In this list India ranks 26 among 30 nations. Few points to note in this study which reveals gendered entrepreneurial phenomenon infused in Indian ecosystem.

i. India ranks better in GEDI Index relative to Gendered GEDI Index hence India is highly gendered on entrepreneurial phenomenon.

ii. India has improved in Gender GEDI-2014 against Gender GEDI-2013 as shown in Chart 1.4 . 
CHART 1.4

Gender GEDI - 2013 vs Gender GEDI - 2014

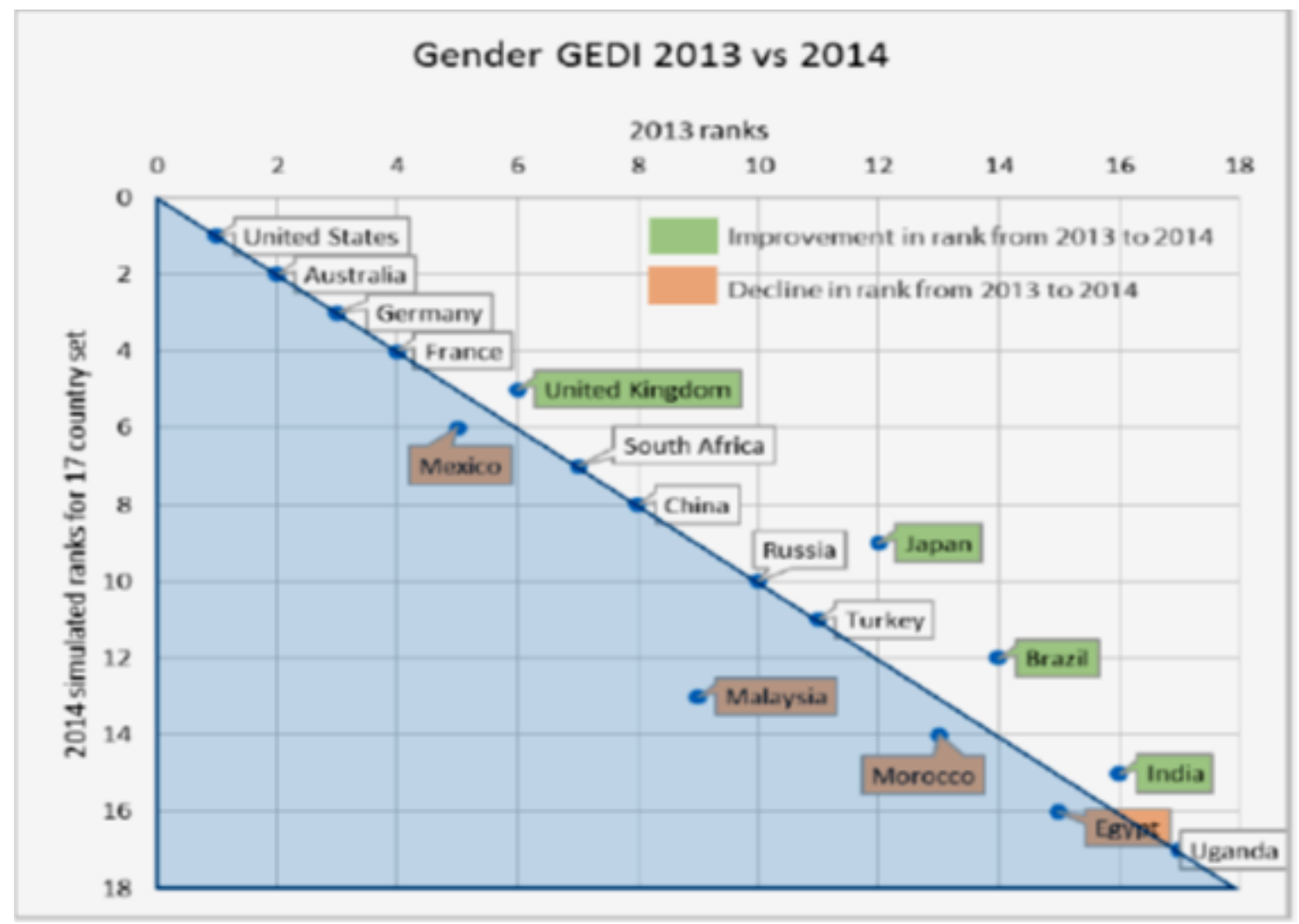

Source-Gender-GEDI Executive Report-2014

iii. One strength of South Asia (India, Pakistan and Bangladesh) is high score for femaleentrepreneurial environment (i.e. 65 per cent of women wants to start a business venture) whereas main challenges they face is with regard to equal legal rights, low female startup and access to technology and low general educational attainment amongst women.

Likewise many studies have been conducted (discussed in detail in Chapter-2) to identify the challenges that make the entrepreneurial voyage convoluted for women-led enterprises. The purpose of this study is to highlight those problems and to identify prospects for women entrepreneurs in the MSME sector of State of Gujarat. In next section let us understand driving force for Gujarat to be the chosen geography for said area of research. 


\subsection{Entrepreneurship in Gujarat}

Entrepreneurship in Gujarat is not a naive concept, rather from the pre-colonial era and even before Gujarat has witnessed generations of entrepreneurs and has evolved to contemporary state. In his article 'Gujarati Entrepreneurship - Historical Continuity against Changing Perspectives' Streefkerk (Streefkerk, 1997) narrates the transition of South Gujarat from pre-machine era to capitalist ind ustry in current. From $19^{\text {th }}$ century to $20^{\text {th }}$ century the various industries for which Gujarat was hub included cotton fabrics in $19^{\text {th }}$ century due to which in later part of $19^{\text {th }}$ century Gujarat was bystander of establishment of numerous cotton mills in the princely state. Between the early $20^{\text {th }}$ century to 1960s Gujarat witnessed the growth of textiles and its related industries like the production of dyes and manufacturing of wooden bobbins and spools especially in South Gujarat. After 1610 British and Dutch East India Company factory establishments nurtured entrepreneurial DNA of Gujarat to such an extent that from 1618 to 1687 Surat was headquarters of British East India Company in western India (Streefkerk, 1997).

In contemporary times Gujarat is known for its rich entrepreneurial history and due to many natural and man-made attractions, Gujarat has earned the title of being 'Growth Engine of India'.

These are few out of many evidences which portray the instrumental role Gujarat has been playing since the very beginning in the arena of business and in developing the entrepreneurial culture in Indian history. In current scenario also the strategic location and business friendly intensive infrastructural growth makes it even more magnetic for furthering the status of business in the state. 


\subsubsection{National data important for the purpose of the study}

Nationally Gujarat is among the top 10 states to house MSMEs as per the records of Annual Report on MSME - 2014 as shown in Table 1.9.

TABLE 1.9

Ten leading States in terms of Number of Enterprises and their respective Employment Generation

\begin{tabular}{|c|c|c|c|c|c|c|c|c|}
\hline \multirow{3}{*}{$\begin{array}{c}\text { Top Ten } \\
\text { State }\end{array}$} & \multicolumn{4}{|c|}{ Total Number of MSME (in lakh) } & \multicolumn{4}{|c|}{ Employment (in lakh) } \\
\hline & \multirow[t]{2}{*}{$\begin{array}{c}\text { Registere } \\
\text { d Sector }\end{array}$} & \multicolumn{2}{|c|}{$\begin{array}{l}\text { Unregistere } \\
\text { d Sector }\end{array}$} & \multirow[t]{2}{*}{ Total } & \multirow[t]{2}{*}{$\begin{array}{l}\text { Regis. } \\
\text { Sector }\end{array}$} & \multicolumn{2}{|c|}{$\begin{array}{l}\text { Unregistered } \\
\text { Sector }\end{array}$} & \multirow[t]{2}{*}{ Total } \\
\hline & & Sample & $\begin{array}{c}\text { EC } \\
\text { 2005* }\end{array}$ & & & Sample & EC 2005* & \\
\hline U.P & 1.88 & 22.34 & 19.82 & 44.03 & 7.55 & 51.76 & 33.06 & 92.36 \\
\hline $\begin{array}{l}\text { West } \\
\text { Bengal }\end{array}$ & 0.43 & 20.80 & 13.41 & 34.64 & 3.60 & 54.93 & 27.24 & 85.78 \\
\hline $\begin{array}{l}\text { Tamil } \\
\text { Nadu }\end{array}$ & 2.34 & 18.21 & 12.58 & 33.13 & 14.26 & 38.89 & 27.82 & 80.98 \\
\hline Maharashtra & 0.87 & \begin{tabular}{|l|}
14.45 \\
\end{tabular} & 15.31 & 30.63 & 10.89 & 24.72 & 34.43 & 70.04 \\
\hline $\begin{array}{l}\text { Andhra } \\
\text { Pradesh }\end{array}$ & 0.46 & 14.90 & 10.60 & 25.96 & 3.83 & 35.15 & 31.71 & 70.69 \\
\hline Kerala & 1.50 & 12.94 & 7.69 & 22.13 & 6.21 & 26.98 & 16.42 & 49.62 \\
\hline Gujarat & 2.30 & 13.03 & 6.46 & 21.78 & 12.45 & 21.97 & 13.31 & 47.73 \\
\hline Karnataka & 1.36 & 11.12 & 7.70 & 20.19 & 7.89 & 22.58 & 16.24 & 46.72 \\
\hline M. P & 1.07 & 11.50 & 6.76 & 19.33 & 2.98 & \begin{tabular}{|l|}
17.32 \\
\end{tabular} & 13.36 & 33.66 \\
\hline Rajasthan & 0.55 & 9.14 & 6.96 & 16.64 & 3.42 & 15.00 & 12.37 & 30.79 \\
\hline
\end{tabular}

* Economic Census - 2005

Source-Annual Report, 2014-15

The western states of Maharashtra and Gujarat continue to dominate Indian industry, together accounting for a share of almost 37 per cent in total revenue added by the nation's factory sector specifically in 2005-2008 (Gujarat-MSME Report, 2013). 


\subsubsection{State Specific Data for the Purpose of the Study}

Gazing at State specific data we can understand that today on business front Gujarat holds a remarkable position by having the title of 'Global Economic Super Power' for having access all important port based economies including UK, China, Australia, Japan, Korea, Gulf Nations etc (Gujarat Official Website). Importance of Gujarat can also be viewed having gone through the following statistics as per the ISED, FICCI Report2013 (Gujarat-MSME Report, 2013):-

i) Gujarat encompasses 4.93 per cent of the population of India with nearly 60 million people.

ii) Gujarat has an impressive literacy rate of 79.3 (M-87.2 and F-70.70).

iii) Gujarat is seventh largest state in terms of geographical area covering extremely strategic location of India i.e. the western coast embracing $1600 \mathrm{~km}$ long coastline which forms 20 per cent of total coastline of India. With this Gujarat is also the Gateway to the rich land-locked Northern and Central vicinity of the nation (Gujarat Official Website).

iv) During 2009-2010 Gujarat's contribution to National GDP was 7.38 per cent.

Since its inception in 1960, Gujarat has shown impressive industrial growth. At the time of inception there were only two major industries existing in Gujarat - Textile and Auxiliaries. Today Gujarat is the land for 13 major industry groups which accounts for 83 per cent of factories, 94 per cent of fixed capital investments, 93 per cent of value of output and 93 per cent of value addition in the state's industrial economy (GujaratMSME Report, 2013). As per the Fourth All India Census of MSMEs, which was conducted during 2006-07 covering all MSMEs registered up to 31/03/2007 with State Industries Commissionerate under MSME Development Act - 2006:-

a. District wise distribution of Working, Closed and Not Found Units is shown in Table.1.10.

b. District wise distribution of MSMEs on basis of gender of owner is shown in Table.1.11. 
TABLE 1.10

District Wise Report on Number of Working, Closed, Not Found Units

\begin{tabular}{|c|c|c|c|c|c|}
\hline Sr.No & District & Working & Closed & $\begin{array}{l}\text { Not } \\
\text { Found }\end{array}$ & Total \\
\hline 1 & Kachchh & 4990 & 752 & 473 & 6215 \\
\hline 2 & Banaskantha & 5162 & 1287 & 389 & 6838 \\
\hline 3 & Patan & 2821 & 655 & 193 & 3669 \\
\hline 4 & Mahesana & 5794 & 1229 & 570 & 7593 \\
\hline 5 & Sabarkantha & 7431 & 1604 & 530 & 9565 \\
\hline 6 & Gandhinagar & 5748 & 1437 & 401 & 7586 \\
\hline 7 & Ahmedabad & 48554 & 1120 & 12864 & 62538 \\
\hline 8 & Surendranagar & 6915 & 1235 & 510 & 8660 \\
\hline 9 & Rajkot & 25007 & 5905 & 1551 & 32463 \\
\hline 10 & Jamnagar & 9785 & 2642 & 695 & 13122 \\
\hline 11 & Porbandar & 1725 & 302 & 85 & 2112 \\
\hline 12 & Junagadh & 6084 & 1528 & 554 & 8166 \\
\hline 13 & Amreli & 2036 & 367 & 260 & 2663 \\
\hline 14 & Bhavnagar & 9635 & 1037 & 1112 & 11784 \\
\hline 15 & Anand & 5591 & 435 & 1 & 6027 \\
\hline 16 & Kheda & 7798 & 1315 & 657 & 9770 \\
\hline 17 & Panchmahal & 3737 & 413 & 0 & 4150 \\
\hline 18 & Dahod & 1417 & 69 & 0 & 1486 \\
\hline 19 & Vadodara & 12948 & 1375 & 1 & 14324 \\
\hline 20 & Narmada & 992 & 196 & 20 & 1208 \\
\hline 21 & Bharuch & 9197 & 2128 & 1710 & 13035 \\
\hline 22 & Surat & 28444 & 7391 & 0 & 35835 \\
\hline 23 & Dang & 514 & 30 & 0 & 544 \\
\hline 24 & Navsari & 4903 & 0 & 169 & 5072 \\
\hline 25 & Valsad & 11350 & 429 & 0 & 11779 \\
\hline 26 & Tapi & 1161 & 64 & 0 & 1225 \\
\hline \multicolumn{2}{|c|}{ Total of Gujarat } & 229738 & 34945 & 22745 & 287428 \\
\hline
\end{tabular}

Source - State Industries Commissionerate, GoG 
TABLE 1.11

District Wise Report on Number of Male and Female Owned MSMEs

\begin{tabular}{|c|c|c|c|c|}
\hline Sr.No & District & Male & Female & $\begin{array}{l}\text { Total No. of } \\
\text { Enterprises }\end{array}$ \\
\hline 1 & Kachchh & 4824 & 166 & 4990 \\
\hline 2 & Banaskantha & 4172 & 990 & 5162 \\
\hline 3 & Patan & 2601 & 220 & 2821 \\
\hline 4 & Mahesana & 5366 & 428 & 5794 \\
\hline 5 & Sabarkantha & 6977 & 454 & 7431 \\
\hline 6 & Gandhinagar & 5460 & 288 & 5748 \\
\hline 7 & Ahmedabad & 47345 & 1208 & 48554 \\
\hline 8 & Surendranagar & 6325 & 590 & 6915 \\
\hline 9 & Rajkot & 22322 & 2685 & 25007 \\
\hline 10 & Jamnagar & 6811 & 2974 & 9785 \\
\hline 11 & Porbandar & 1651 & 74 & 1725 \\
\hline 12 & Junagadh & 5847 & 237 & 6084 \\
\hline 13 & Amreli & 1819 & 217 & 2036 \\
\hline 14 & Bhavnagar & 9274 & 361 & 9635 \\
\hline 15 & Anand & 4635 & 956 & 5591 \\
\hline 16 & Kheda & 7464 & 334 & 7798 \\
\hline 17 & Panchmahal & 2149 & 1589 & 3737 \\
\hline 18 & Dahod & 1123 & 294 & 1417 \\
\hline 19 & Vadodara & 9838 & 3111 & 12948 \\
\hline 20 & Narmada & 895 & 97 & 992 \\
\hline 21 & Bharuch & 8408 & 789 & 9197 \\
\hline 22 & Surat & 24807 & 3637 & 28444 \\
\hline 23 & Dang & 488 & 26 & 514 \\
\hline 24 & Navsari & 4202 & 701 & 4903 \\
\hline 25 & Valsad & 10301 & 1049 & 11350 \\
\hline 26 & Tapi & 1007 & 154 & 1161 \\
\hline \multicolumn{2}{|c|}{ Total of Gujarat } & 206109 & 23629 & 229738 \\
\hline
\end{tabular}

Source - State Industries Commissionerate, GoG

Out of the total number of MSMEs only 10.3 per cent of enterprises are owned by women entrepreneurs as per the data of Gujarat MSME Report - 2013. If we try to connect three dots, firstly the historical presence of Gujarat in the field of entrepreneurship, secondly the fact of having the legacy of initiative like 'Lijjat Papad' which was started in around 1959 in Mumbai by seven Gujarati women and lastly the 
fact of presence of only 10.3 per cent of women enterprises in total MSME sector, shows that there is a gap which needs to be filled to witness the equal participation of women entrepreneurs in the national economy. It is rather need of the time to identify the gap.

\subsection{National and State Schemes for Women Entrepreneurs}

\subsubsection{National Schemes}

1.8.1.1. Training of Women Entreprene urs -Entrepreneurship can be encouraged among people by providing them right kind of guidance and training; this was firstly proposed by McClelland. Government has been active in this field and regularly announces training programmes particularly for first generation women entrepreneurs and special focus has now been given to exclusive women training.

- NIESBUD, Noida - National Institute of Entrepreneurship and Small Business Development, Noida is the regulatory institution which in accordance with the policies and guidelines regulates the training programmes being conducted by various Entrepreneurship Development Institutions across India like EDI, CED etc. Women entrepreneurs as target group has received it special attention and till December, 2014 nearly 31,813 women, which forms almost 25 per cent of total participants, have received training by different activities like Workshops, Seminars, Entrepreneurship cum - Skill Development Programmes, Management Development Programmes (Annual Report - 2014).

- NI-MSME, Hyderabad -National Institute for Micro, Small and Medium Enterprises, an autonomous body of Ministry of Micro, Small and Medium Enterprises, was established in 1960. In the 2014-15 (upto Dec 2014) it provided training to 2393 women entrepreneurs (Annual Report - 2014).

- IIE, Guwahati - Indian Institute of Entrepreneurship, Guwahati is an autonomous organization under the aegis of Ministry of Skill Development and Entrepreneurship was established in 1993 and started operating in 1994 currently gives training under two 
schemes i.e. Assistance to Training Institutions (ATI) Scheme \& Non ATI Scheme. Upto December 2014 it provided training to 8.226 women entrepreneurs under various schemes including women entrepreneurs from rural area (Annual Report, 2014)

- NSIC -Established in 1955 National Small Industries Corporation has been active in development of small industries under various schemes and services for marketing assistance, bank credit facilitation, performance and credit ratings, raw material assistance, single point registration, infomediary services, marketing intelligence etc. According to Annual Report on MSME - 2014 NSIC provided training to 25,897 women entrepreneurs during 2014-15 (upto December 2014).

\subsubsection{Trade Related Entrepreneurship Assistance and Development (TREAD)}

Scheme - There are three major components of the scheme (Annual Report - 2014)-

- Government grants up to 30 per cent of loan/credit sanctioned by banks to NGO's to provide expert assistance to start-up ventures as proposed in the project.

- Government grants up to Rs. 1 lakh per programme to training institution/NGO to impart training to the women entrepreneurs subject to such institution/NGOs contribute up to 25 per cent of their share of GoI grant and 10 per cent in case of NER.

- Need based Governments grant up to Rs. 5 lakh to National Entrepreneurship Development Institutions and any other institutions of repute for activities like field surveys, research studies, evaluation studies, designing and training modules etc.

\subsubsection{Micro and Small Enterprises Cluster Development (MSE-CDP) (MSME} Schemes, 2016)- This scheme provides financial assistance to special purpose vehicle companies set up by cluster units for common facility center, infrastructures, skill development training and quality upgradation etc. In this scheme financial assistance of 90 per cent of the project cost (against 70 per cent in case of male entrepreneurs) is provided by GoI for soft interventions, hard intervention and financial assistance of 80 per cent of project cost is provided to the women entrepreneurs.

1.8.1.4. Prime Ministers Employment Generation Programme and Women - The scheme is implemented by Khadi and Village Industries (KVIC) which functions as 
nodal agency at national level. At the state level the scheme is put into practice by State KVIC Directorates, State Khadi and Village Industries Boards (KVIBs), District Industries Centre (DICs), and Banks (MSME Scheme, 2016). Special incentives as follows are provided to women entrepreneurs (Annual Report - 2014)-

- Provision of margin money subsidy of 25 per cent of the project cost to urban women and 35 per cent of the total project cost to rural women entrepreneurs.

- In case of women entrepreneurs, beneficiary's contribution is 5 per cent of total project cost against 10 per cent in general case.

- 95 per cent of bank finance of total project cost is provided to women entrepreneurs while it is 90 per cent in general cases.

72,754 women entrepreneur projects have been financed under this scheme since its inception in 2008-09 to 31.1.2015 (Annual Report - 2014).

1.8.1.5. Skill upgradation and Mahila Coir Yojana - This is one of the flagship schemes under the aegis of Scheme Coir Vikas Yojana which aims to provide development to domestic and export markets, development of skill and provide training, women empowerment, employment/entrepreneurship creation and development and the like. Mahila Coir Yajana basically provides assistance to women by providing them spinning equipments at subsidized rates after providing specialized training (MSME 2016).

1.8.1.6. National Award Scheme- Under this scheme GoI recognizes the efforts of different group of entrepreneurs to make noticeable contribution as entrepreneur in MSME sector. A cash prize of Rs. 1 lakh is awarded to women entrepreneurs for their outstanding contribution in specifically in manufacturing sector (MSME Scheme, 2015).

1.8.1.7. Personal Accident Insurance' Scheme Coir Worke rs - The Coir Board is implementing the plan scheme 'Welfare Measure - Coir Workers Group Personal Accident Insurance' scheme is providing financial compensation to deceased/disabled coir worker or nominee. Under this scheme it is observed that majority of coir worker 
are women hence accident in their case includes death or disability due to pregnancy, child birth, breast removal even in cases of murder or rape etc (MSME Scheme, 2015).

1.8.1.8. National Programme for Youth and Adolescent Development - It envisions developing the youth personality and imparting leadership qualities in them to channelize their energy for socio-economic development of the nation. This scheme aims to have at least one-third participation from women beneficiary (MSME Scheme, 2015).

\subsubsection{Development/Upgradation of Watermills and Setting up Micro Hydel Projects (Up to 100 KW Capacity) - The Water Mills (WM) and Micro Hydel Projects (MHP) have the capacity to bring solution to power requirements of village or remote areas. In this scheme special preference is given to WM owned by women entrepreneurs or project proposal received from women NGOs (MSME Scheme, 2015).}

1.8.1.10. Women Enterprise Development - The scheme gives assistance to women entrepreneurs of age group of 18-50 years to start-up business ventures. Assistance is also provided to already existing women entrepreneurs for expansion, modernization and diversification (MSME Scheme, 2015).

1.8.1.11. North-East Rural Livelihoods Project (NERLP) - It aims at improving livelihoods especially that of women, unemployed youths and the most disadvantaged section of participating North-Eastern States. This is a World Bank funded Scheme. It has four components (MSME Scheme, 2015) -Social empowerment, economic empowerment, partnership development and project management.

1.8.1.12. Sche me of Venture Capital Fund for Scheduled Cast - It is a social sector National level scheme for the promotion of entrepreneurship development among the scheduled caste population of our India. It also encourages those SC people who show 
special orientation towards innovation and growth technologies. In this scheme while selection women SC entrepreneurs are given preference (MSME Scheme, 2015).

1.8.1.13. Adivasi Mahila Sashaktikaran Yojana - It is a concessional scheme for the economic development and empowerment of ST women (MSME Scheme, 2015).

1.8.1.14. Micro Credit (MC) for SHGs - In this scheme ST women are given financial assistance to start up self employed venture through profit making SHGs only (MSME Scheme, 2015). Loan amount of Rs. 35,000 per member up to Rs. 5 lakh per SHG is being provided.

\subsubsection{Support to training and Employment Programme (STEP) for Women - It provides training with regard to skill development, access to credit and enable them to initiate income generation activity. Under this 100 per cent, 50 per cent and 30 per cent of financial assistance of total project cost on an year wise basis is provided to women entrepreneurs (MSME Scheme, 2015).}

1.8.1.16. Pradhan Mantri Mudra Yojana - Under Micro Units Development and Refinance Agency Limited, which was launched on 8 April, 2015 (MUDRA Scheme, 2015), small women entrepreneurs will be extended financial assistance from Rs. 50,000 to Rs. 10 lakh.

1.8.1.17. Stand - up India - Flagship schemes of Stand-up India aims to promote entrepreneurship among SC/ST and women by providing them finance from 10 lakh to 100 lakh in establishing a Greenfield enterprise. 


\subsubsection{State Schemes for Women Entrepreneurs}

\subsubsection{Schemes under Women and Child Development Department (WCD), GoG (WCD, 2015):-}

a) Multi Purpose Women Welfare Centers - This center has been established to render guidance and assistance for any sort of social, economical or legal problems. Over 4.17 lakh women have been benefited from this scheme till 2014.

b) Mahila Puraskar - Introduced by WCD, GoG to facilitate an individual or an organization for its extraordinary contribution towards women welfare, women empowerment and sustainable development. Rs. 200,000 has been dedicated in the 201617 for the implementation of this scheme (Commissionarate of WCD).

c) Swayamsidh Yojana - It is an integrated effort for women socio-economic-cultural empowerment to help rural women to be self reliant, gain confidence and learn the benefits of saving. As per WCD newsletter (2015) this project planned to benefit 20 regions covering 26 spots and 1760 villages which include 43,200 women.

d) Fisher Entrepreneur Yojana- This scheme encompasses SC/ST women and encourages them to undertake fish selling as a source of income generation. Special training to grow 'Zingo fish' is given to women and they are paid a stipend of Rs.100 to attend training under this scheme. For the purpose, required instruments and facility is provided to buy weighing machine, insulated box, etc. On average Rs.10, 000/- Unit cost, 50\% assistance is given to women belonging to scheduled caste/tribe.

\subsubsection{Schemes under Gujarat Women's Economic Development Corporation (GWEDC):-}

A functionary under Women and Child Development Department, GoG, established in 1981, the corporation aims the holistic development of economically and socially weak women. It facilitates initiatives like financial support, trainings (after successful completion of training the women are linked to banks for financial support), and 
marketing support to urban and rural women artisans to make them self reliant. Some schemes encompassed under this are (GWEDC):-

a) Ghar Divda Bankable Finance Scheme - Under this scheme the banks of respective area are directed to accept loan applications pertaining to undertaking economic activities for upto Rs. 50,000. Under this scheme approximately 1137 women entrepreneurs' women beneficiaries have been benefited till March, 2012.

b) Exhibition cum Sale - This scheme assists the urban and rural artisans to market their products nationally and on state level by organizing craft melas and bazaars one per year outside Gujarat and four per year within Gujarat respectively.

c) General Training Program - For the economic empowerment of BPL women aging between 18-35 years bracket skill training ranging from making soft-toys, patch work, electric appliance repairing, beauty parlor to computer literacy are provided under this program with the help of NGOs. A total of 3593 women have been trained under this scheme till March, 2012.

d) Economic Rehabilitation of Women in Difficult Circumstances - Under the aegis of this scheme economic rehabilitation is undertaken for women in difficult situations with the help of NGOs. An allocation of Rs. 300 lakh had been dedicated to this program implementation for the year 2012-2013.

e) Women Empowerment Centre - A centre has been established for all those women who are engaged in economic as well as skill development related activities in GWEDC. A sum of Rs. 100 Lakh had been dedicated for the establishment of this centre in the year 2012-2013.

\subsubsection{Industries Commissionarate Scheme, Government of Gujarat (Industries Commissionarate)-}

a) Assistance for reimbursement of CGTMSE fees for Micro and Small Enterprises (Industries Commissionarate) - This scheme provides financial subsidy by way of capital subsidy and credit linked interest subsidy to MSMEs. This scheme is entitled to only those manufacturing enterprises which are registered under MSME Development Act, 2006 with respective District Industries Commissionarate (DIC). In special 
provision women entrepreneurs, those who are availing collateral free term loan upto Rs. 1 Crores from financial institutions / Bank under CGTMSE will be eligible.

\subsubsection{Gujarat Chambers of Commerce and Industries (GCCI) -}

a) Business Women's Wing (BWW) - GCCI established Business Women's Wing on $20^{\text {th }}$ July, 1985 to promote social, cultural and educational interests of women entrepreneurs and provide encouragement to varied sector of women entrepreneurs to be self reliant. BWW, GCCI in its presence of 4 decades facilitated women entrepreneurs by means of organizing oversees delegations, seminars, conferences, open house discussions and giving a platform to articulate problems faced by women entrepreneurs in their day to day business activities thereby providing solution to the same.

\subsubsection{Gujarat Industrial Development Corporation (GIDC)-}

a) Women Industrial Park - In a women entrepreneur friendly initiative GIDC has allocated land to 76 women entrepreneurs on a lease of about 99 years in the first ever Women Industrial Park, Sanad. In the initial drive this park is facilitated with basic amenities like roadways, streetlights, power supply and water distribution (Indian Express, 2016).

\subsection{Statement of Problem}

A thorough discussion of the concepts 'Entrepreneurship', 'MSME' and 'Women Entrepreneurship', the evolution of entrepreneurship nationally as well as on the state front, a brief evolution of women entrepreneurship in India and the various measures/schemes federal and state governments are taking by the intervention of numerous public/private agencies, NGOs etc, and the entire review of literature (Chapter - 2) are able to give us fair understanding of entrepreneurship as a phenomenon. It is 
evident that even though Gujarat has a rich entrepreneurial cultural history since precolonial era it does not outperform in the field of entrepreneurship and especially when points like 'Entrepreneurship being Gendered' are raised, Gujarat related facts and figures remains mediocre. This fact of ' 10.3 per cent of women entrepreneurs out of a total of 2, 29,738 MSMEs' makes the author inquisitive about the reason behind this phenomenon. Author is unable to understand the root cause/s of this gap. On an in depth probing author came to the conclusion that in Gujarat there is a dire need of a state specific empirical survey with women entrepreneurs as a focal point. Upon this author seeks to carry out a state wide study with 'Women Entrepreneurs' as subject to peep into their psyche and with their experience sharing to extract details with regard to following research questions-

a) What is the profile of the businesses run by women entrepreneurs in Gujarat?

b) What are the reasons responsible for women to join or establish business start-up (Necessity based or Opportunity Based)?

c) Does demographic and socio-economic background of women has an impact on their perceptions pertaining to problems they face in the various business related activities?

d) What is the size of women owned businesses?

e) What the ratio is, of registered to unregistered firms in case of women owned businesses from the total number of samples collected?

f) Does attending Entrepreneurship Development Programmes bring change in the profit of women owned businesses?

g) What are the various enabling factors for women entrepreneurs to start-up and sustain in a business?

h) What are various important problems faced by women entrepreneurs with respect to Finance, Personal, Social, Raw Materials, Marketing, Labor, Managerial Skills, Infrastructure, Technology, and Government Support?

i) What are the various prospects for women entrepreneurs in Gujarat as a market and culture? 


\section{References}

Rama M (2003) 'Globalization and the workers in Developing Countries' World Bank Policy research working paper- 2958. Retrieved from file://C:/Users/CG/Downloads/SSRNid2660590.pdf

Naidu V, (2009, Jan 9) 'Promoting Entrepreneurship in India', The Economic Times. Retrieved 28 July, 2016 from http:/articles.economictimes.indiatimes.com/2009-0106/news/28462527_1_entrepreneurship-financial-crisis-employment

Punj S, Arun MG (2016, April 20) "Where are the jobs" India Today In. Retrieved $28^{\text {th }}$ July, 2016 from http//indiatoday.intoday.in/story/employment-scenario-job-crunch-joblessgrowth-economy/1/647573.html

Knotek, Edward S., II. (2007, Jan 11) "How Useful Is Okun's Law?" Federal Reserve Bank of Kansas City, Economic Review, vol. 92, no. 04, pp. 73-103. Retrieved 29 ${ }^{\text {th }}$ July, 2016 from https://www.kansascityfed.org/publicat/econrev/pdf/4q07knotek.pdf

Gupta, G.S. (2002). Economic Fluctuations and Stabilization Policies.Presented at Sixth Dr. D.K.Shukla Memorial Lecture, Department of Economics, M.S.University Baroda on December28, 2002. Retrieved on $24^{\text {th }}$ December, 2016 from http://iima.ac.in/assets/snippets/workingpaperpdf/2003-01-04GSGupta.pdf

Faria J.R, Cuestas J.C, Gil-Alana Luis A. (2009) 'Unemployment and entreprneurship : A cyclical relation'. Economic Letters 105 (2009). Pg 318-320. Retrieved from http://ac.elscdn.com/S016517650900305X/1-s2.0-S016517650900305X-main.pdf?_tid=e6f6e3ca-554a11e6-b7c9-00000aacb35f\&acdnat=1469769267_95810bce4c0138033588b61a5b7fae99

Bokhari, A.A.H (2012) 'Entrepreneruship as a solution to Youth Unemployment in the Kingdom of Saudi Arabia' American Journal of Scientific Research. Issue 87 Pg 124. Retrieved from https://www.researchgate.net/publication/292615854_Entrepreneurship_as_a_Solution_to_Y outh_Unemployment_in_the_Kingdom_of_Saudi_Arabia 
Bygrave, W., Zacharakis, A. (2011). 'Entrepreneurship'. Pg 25-26. $2^{\text {nd }}$ Ed. John Wiley \& Sons Inc. Retrieved from http:/www.roletech.net/books/Entrepreneurship2ndEdition.pdf

Kritikos A. S, (2014) Entrepreneurs and their impact on jobs and economic growth. Pg.3 IZA World of Labor. DOI: 10.15185/izawol.8. Retrieved from http://wol.iza.org/articles/entrep reneurs-and-their-impact-on-jobs-and-economic-growth1.pdf

Stam E \& Garnsey E.W (2007) 'Entrepreneurship in Knowledge Economy” Pg 1.SSRN Electronic Journal. DOI : 10.2139/ssrn.1923098. Retrieved on $19^{\text {th }}$ August, 2016 from https://www.researchgate.net/publication/46711713_Entrepreneurship_in_the_knowledge_ec onomy

U.S. Department of State/Bureau of International Information Programs Document. Retrieved $4^{\text {th }}$ July, 2016 from http://www.ait.org.tw/infousa/zhtw/DOCS/enterp.pdf

Desai V, (2014) 'The dynamics of Entrepreneurial Development and Management'. (5 ${ }^{\text {th }}$ ed) Himalaya Publishing

Aspromourgos T (2012) 'Entrepreneurship, Risk and Income Distribution in Cantillon's Essai' pg.1

Naude W, (2011), 'Entrepreneurship and Economic Development'.Series in Development Economics and Policy. Pg 5.Palgrave Macmillan

The Economist (27 ${ }^{\text {th }}$ April, 2009). Entrepreneurship. Retrieved from http://www.economist.com/node/13565718

Miryala, R.K \& Aluvala, R (2015).Trends, Challenges and Innovations in Management Volume II.Pg. 62.Zenon Academic Publishing. Retrieved from https:/books.google.co.in/books? id=jExzCQAAQBAJ\&pg=PA62\&lpg=PA62\&dq=Who+coi ned+the+term+first+Richard+Cantillon+or+Jean+Baptiste+Say\&source=bl\&ots=Y6RRKg3S w_\&sig=UZP6YS40Q7jxYAUXwBqn6oHUGXo\&hl=en\&sa=X\&ved=0ahUKEwit8MSozIL 
PAhVLqY8KHcwGD_wQ6AEIPDAF\#v=onepage \&q=Who\%20coined\%20the\%20term\%20 first\%20Richard\%20Cantillon\%20or\%20Jean\%20Baptiste\%20Say\&f=false

Ahmad N, Seymour R.G (2008) 'DEFINING ENTREPRENEURIAL ACTIVITY:

Definitions Supporting Frameworks for Data Collection' OECD Statistics Working Papers, 2008/01, OECD Publishing, Paris. Retrieved on $4^{\text {th }}$ July, 2016 from http://dx.doi.org/10.1787/243164686763

Aspromourgos T (2012) 'Entrepreneurship, Risk and Income Distribution in Cantillon's Essai’ pg.1

Gartner, W. B. (1988). "Who is an entrepreneur?" is the wrong question. American Journal of Small Business, /i(Spring), 11-32.

Schumpeter, J A. 1934. The Theory of Economic Development: An Inquiry into Profits, Capital, Credit, Interest, and the Business Cycle. Cambridge, MA.: Harvard University Press.

Kirzner, I. M. 1973. Competition and entrepreneurship. Chicago: University of Chicago Press.

Knight, F. H. ( 1921) Risk, Uncertainty and Profit. New York: Harper.

Say, Jean Baptiste (1803). A Treatise on Political Economy, Philadelphia: Lippincott Grambo.

Mokaya, S.O., Namusonge, M., and Sikaleih, D. (2012).The Concept of Entrepreneurship; In Pursuit of a Universally Acceptable Definition.Pg. 133.International Journal of Arts and Commerce.Vol. 1 No. 6. November, 2012. Retrieved from http:/www.ijac.org.uk/images/frontImages/gallery/Vol._1_No._6_/13.pdf

Filion, L.J. (2011). Defining the Entrepreneur. Dana, L.P (Ed). World Encyclopedia of Entrepreneurship(pp 41-52). Cheltenham, UK; Northampton, MA, USA: Edward Elgar 
Goswami, A., Dalmia, N. and Pradhan, M. (2008).Entrepreneurship in India.National Knowledge Commission Report - 2008. Retrieved from http://knowledgecommissionarchive.nic.in/downloads/documents/NKC_Entrepreneurship.pd $\mathrm{f}$

Amoros, J.E. and Bosma, N. (2014).Global Entrepreneurship Monitor 2013 Global Report. . Babson Park, MA, U.S.: Babson College; Santiago, Chile: Universidad del Desarrollo; Malaysia: Universiti Tun Abdul Razak; London, U.K: London School of Business and London, U.K.: Global Entrepreneurship Research Association. Retrieved from http://www.babson.edu/Academics/centers/blank-center/globalresearch/gem/Documents/GEM\%202013\%20Global\%20Report.pdf

Sanjeevan, G. (2012). Present Status of MSME Statistics.The Journal of Industrial Statistics.1 (2). 269-282. Retrieved from http://mospi.nic.in/mospi_new/upload/JIS_2012/Present_Stat_MSME_Stats_corr_sep12.pdf

Economy, I.A.G (2004).Promoting SMEs for Development. $2^{\text {nd }}$ OECD Conference of Ministers Responsible for Small and Medium Sized Enterprises (SMEs). 3-5 June, 2004. Istanbul, Turkey.Retrieved from http://www.oecd.org/cfe/smes/31919278.pdf

IFC (2010). Micro, Small, and Medium Enterprises Around the World : How Many are There, and What Affects There Count. World Bank/IFC MSME Country Indicators- 2010. Retrieved from http:/www.ifc.org/wps/wcm/connect/9ae1dd80495860d6a482b519583b6d16/MSME-CIAnalysisNote.pdf?MOD=AJPERES

MSME (2010).Report of Prime Minister's Task Force on Micro, Small, Medium Enterprises. January, 2010. Retrieved from http:/msme.gov.in/pm_msme_task_force_jan2010.pdf

IFC Report (2014). Improving Access to Finance for Women-owned Businesses in India.Retrieved from http:/www.ifc.org/wps/wcm/connect/a17915804336f2c29b1dff384c61d9f7/Womenownedbu siness1.pdf?MOD=AJPERES 
Development Commissioner-Micro Small Medium Enterprises. Government of India Website. Retrieved on $11^{\text {th }}$ September, 2016 from http:/www.dcmsme.gov.in/ssiindia/defination_msme.htm

Smith-Hunter, A. (2013). Women entrepreneurs in the global marketplace.Edward Elgar Publishing. Retrieved from https:/books.google.co.in/books?hl=en\&lr=\&id=scl_fpIH74YC\&oi=fnd\&pg=PR1\&ots=COz sfFCZeR\&sig=ThQ1tZ5A5bpBqsXOIf6xpn4wPQo\#v=onepage\&q\&f=false

Census India (2001).Gender Composition. Retrieved from http://censusindia.gov.in/Census_And_You/gender_composition.aspx

Sharma, A. (2013). Women Entrepreneur in India.IOSR-Journal of Business and Management. Vol. I5 Issue 3. (Nov-Dec, 2013). PP 09-14. Retrieved from http://iosrjournals.org/iosr-jbm/papers/Vol15-issue3/C01530914.pdf

Economy, I. A. G. (2004). Women's Entrepreneurship: Issues and Policies. Retrieved from http://www.oecd.org/cfe/smes/31919215.pdf

Cherukara, J. and Manalel, J. (2011). Evolution of Entrepreneurship Theories Through Different School of Thoughts. At the Ninth Biennial Conference on Entrepreneurship at Entrepreneurship Development Institute of India on Feb 16-18, 2011. Retrieved from https://www.researchgate.net/publication/287208107

Bula, O.H. (2012). Evolution and Theories of Entrepreneurship: A Critical Review of Kenyan Perspective. International Journal of Business and Commerce.Vol.1, No.11. 9pp-81-96). Retrieved from http//www.ijbcnet.com/1-11/IJBC-12-11106.pdf

Down, S. (2010). Enterprise, Entrepreneurship and Small Business.Cornwall; UK. Sage Publication

Barreira, J. (2010). Early Thinking and The Emergence of Entrepreneurship. In Urban, B. (Ed). Frontiers in Entrepreneurship (pp 1-32). Berlin, Germany:Springer-Verlag. DOI 10.1007/978-3-642-04502-8. 
Rocha, V.C. (2012). The Entrepreneur in the Economic Theory: From an Invisible Man Toward a New Research Field. FEP Working Papers. N.459 May, 2012. Retrieved from http:/www.fep.up.pt/investigacao/workingpapers/wp459.pdf

Casson, M. (2004).Entrepreneurship and the Theory of the Firm.Workshop on Alternative Theories of the Firm, ATOM. November 2002. Paris. Retrieved from http:/www.reading.ac.uk/web/FILES/business/emdp008-04.pdf

Yu, T.F.L. (2001). Entrepreneurial Alertness and Discovery. Pp. 47-63. The Review of Autrian Economics. 14:1. Netherland. Kluwer Academic Publisher. Retrieved from http:/www.gmu.edu/depts/rae/archives/VOL14_1_2001/3_yu.pdf

Luiz, J.M. (2010). Economic Perspectives of Entrepreneurship. In Urban, B. (Ed).Frontiers in Entrepreneurship (pp.63-84). Berlin, Germany: Springer-Verlag. DOI 10.1007/978-3-64204502-8.

Ebner, A. (2005). Entrepreneurship and Economic Development. Journal of Economic Studies.Vol. 32 No.3, 2005.pp.256-274. Emerald Group Publishing. DOI 10.1108/01443580510611047. Retrieved from http:/www.fb03.unifrankfurt.de/48286260/Ebner_2005_Entrepreneurship-and-economic.pdf

Berger, B. (1991). The Culture of Entrepreneurship. San-francisco, California : ICS Press. Retrieved from http^/pdf.usaid.gov/pdf_docs/PNABM799.pdf

Jones, G. \& Wadhwani, R.D. (2006). Schumpeter's Plea: Rediscovering History and Relevance in the Study of Entrepreneurship. Harvard Business School Working Paper, 06036. Retrieved from http://www.hbs.edu/faculty/Publication\%20Files/06-036.pdf

Frese, M. (2009).Toward a Psychology of Entrepreneurship - An Action Theory Perspective.Foundations and Trends in Entrepreneurship.Vol.5 No.6 (2009).DOI 10.1561/0300000028. Retrieved from http://www.evidence-basedentrepreneurship.com/content/publications/447.pdf 
UNCTAD (2005). Entrepreneurship And Economic Development : The Empretec Showcase. United Nations Conference on Trade and Development, Geneva, 2004. Retrieved from http://unctad.org/en/Docs/webiteteb20043_en.pdf

Hamilton, R.T. and Harper, D.A. (1994).The Entrepreneur in Theory and Practice.Journal of Economic Studies.Vol. 21.No. 6. (pp.3-18). Retrieved from http://dl.wecouncil.com/Octal/db/Files/1009880882_Session\%201\%20\%20The\%20Entrepreneur\%20in\%20Theory\%20and\%20Practice.pdf

Ostergaard, A. (2014). The Challenges of Measuring the Entreprenurial Personality? A Methodological Approach. DRUID Society Conference, June 16-18, 2014. CBS, Copenhagen. Retrieved from http://druid8.sit.aau.dk/acc_papers/f4sr0nm7pq8gs48sapq0rlx50ei1.pdf

Thronton, P.H. (1999). The Sociology of Entrepreneurship.Annual Review of Sociology. Vol.25.(pp.19-46). Retrieved from file://D:/data/cg/Desktop/Thesis\%20Material/Reference\%20Material/The_Sociology_of_Ent repreneurship.pdf

Vu, D.L.N., Napier, N.K. and Hoang, V.Q. (2012). It Take Two to Tango: Entrepreneurship and Creativity in Troubled Time in Vietnam 2012. CEB Working Paper N 12/022 2012. Université Libre de Bruxelles. Retrieved from file ///D:/data/cg/Desktop/Thesis\%20Material/Reference\%20Material/wp12022.pdf

Rauch, A., \& Frese, M. (2000). Psychological approaches to entrepreneurial success. A general model and an overview of findings. In C.L. Cooper \& I.T. Robertson (Eds.), International Review of Industrial and Organizational Psychology (pp. 101-142). Chichester: Wiley. Retrieved from http://www.postgraduates.net/wps/pgn/dl/down/open/ebme_de/8641a73d74e61273585547d34d69a47f9ec27f 83e00c3b6e6f8b398e49b8a863f4c67960632a0a66f10fc7ef9db33cb4/Psychological_approach es_to_entrepreneurial_success.pdf

Chell, E. (2008). The Entrepreneurial Personality - A Social Construction.Second Edition.Hove, East Sussex: Routledge (Taylor and Francis). Retrieved from 
http://d14a.org/uploads/pdf/0415328098.Psychology.Press. The. Entrepreneurial.A.Social.Cons truction.Jun.2008.pdf

Filion, L.J. (1998). Two Types of Entrepreneurs: Operator and Visionary Consequences for Education. Working paper no. 1998-11 September 1998 and presented at the Rencontres de St-Gall 1998 held in Elm (Switzerland), September 28 - October 2nd, 1998, published in Pleitner, H.J. (Ed.) 1998 Renaissance of SMEs in globalized economy, p. 261-270. Retrieved from http://web.hec.ca/creationdentreprise/CERB_Backup-12-mai-2008/pdf/199811PRATwoTypesEntrepreneurs.pdf

PWC India (2014) 'Future of India- The Winning Leap' Pg 74.PWC. Retrieved from https://www.pwc.in/assets/pdfs/future-of-india/future-of- india-entrepreneurs.pdf

Audrestch D B \& Meyer N S (2009) 'Religion, Culture and Entrepreneurship in India' Paper presented in IPAA 2009 International Public Affairs Conference at Indiana University, Bloomington. Retrieved from http//www.indiana.edu/ iunews/IPAAAudretsch.pdf

Tripathi D (1971). Indian Entrepreneurship in Historical Perspective: A Re-Interpretation. Pg - M 59.Economic and Political Weekly.Vol.6, No.22 (May 29, 1971). Retrieved from http:/www.jstor.org/stable/4382059?seq=1\#page_scan_tab_contents

Hazen, Walter (2003). Inside Hinduism.Pg. 4 Miliken Publishing. Retrieved from http://www.teachinteract.com/pdf/MK389EX_InsideHinduism.pdf

Kumar A (2002). Encyclopedia of Teaching of Agriculture.Pg. 411.Anmol Publications. ISBN 978-81-261-1316-3

Pahurkar, R. N. (2011). An empirical study of problems and prospects of entrepreneurship development through management education with special reference to university of Pune.Unpublished PhD Thesis.University of Pune. Retrieved from http://shodhganga.inflibnet.ac.in/bitstream/10603/2022/8/08_chapter-1.pdf

Tata Central Archives.Circa 1900. Jamsetji Nusserwanji Tata (1839-1904) http://www.tatacentralarchives.com/publications/booklets/JNTATA.pdf 
Gopalakrishnan R (2014). The Legend and his legacy - The Tata Samaskar.Pg 42. Tata Review. Jan 2014. Retrieved from http://www.tata.in/ebook/tata_review_jan_2014/consolidated_tata_review_jan_2014.pdf

Shankar, R K (2009).The rise and rise of Indian Entrepreneurism.Tapasya - A Magazine by Indira Institute of Management, Pune.Monsoon Edition. Retrieved from https:/www.researchgate.net/publication/275644537_The_rise_and_rise_of_Indian_Entrepre neurism

Tabe, N \& Garriappa, S. (2013) Entreprneurship Development in India - Emergence from Local to Global Leadership.Kalpaz Publications. ISBN:978-81-7835-989-2. Retrieved from http://repository.meijigakuin.ac.jp/dspace/bitstream/10723/1697/1/Entrepreneurship_Develop ment_in_India.pdf

Komiya, R (1959). A Note on Professor Mahalanobis' Model of Indian Economic Planning. The Review of Economics and Statistics.Pp. 29-35.Vol. 41. No. 1 (Feb, 1959). The MIT Press. Retrieved from http//www.jstor.org/stable/1925455

Essays, UK. (November 2013). Nationalization Of Banks In India The Economic Effect Economics Essay. Retrieved from https://www. ukessays.com/essays/economics/nationalisation-of-banks-in-india-theeconomic-effect-economics-essay.php?cref=1

Kotwal, A., Ramaswami, B., and Wadhwa, W. (2011). Economic Liberalization and Indian Economic Growth: What's the evidence? Discussion Paper 11-13. Indian Statistical Institute, Delhi. Retrieved from http:/www.isid.ac.in/ pu/dispapers/dp11-13.pdf

Ravi, S. (2014). What Drives Entrepreneurship? Some Evidence from India.Brookings Institution India Center, 14-15. Retrieved from http//www.brookings.in/wpcontent/uploads/2014/08/Ravi-Entrepreneurship-Working-Paper.pdf 
Secretariat, R. S. (2009).Global Economic Crisis and Its Impact on India.Occasional Paper Series (4).Rajya Sabha. New Delhi. Retrieved from http://rajyasabha.nic.in/rsnew/publication_electronic/glob_eco_crisis2009.pdf

Verick, S., \& Islam, I. (2010). The great recession of 2008-2009: causes, consequences and policy responses. Discussion Paper Series. IZA DP No. 4934. Retrieved from http://tp.iza.org/dp4934.pdf

UNCTAD (2010).The Financial and Economic Crisis of 2008-2009 and Developing Countries.UNCTAD/GDS/MDP/2010/1.United Nations Publications. http://unctad.org/en/Docs/gdsmdp20101_en.pdf

PwC and CII (2011). Innovation: Changing the MSME Landscape. PwC and CII Publication. Retrieved from https://www.pwc.in/assets/pdfs/publications-2011/innovation-msme-2011.pdf

CII and PwC. (2010).Creating Competitive SMEs.PwC and CII Publication. Retrieved from http:/www.cii.in/webcms/Upload/Creating\%20Competitive\%20SMEs.pdf

MSME Annual Report (2014-15), Government of India.

Alsos, G.A., Jensen, R.S. \& Ljunggren, E. (2010).Women Entrepreneurs and the Global Environment for Growth.Brush, C.G., Bruin, A.D., Gatewood, E.J., Henry, C. (Ed). Gender and Entrepreneurship: revealing constructions and underlying processes - the case of Norway (pp. 40-56). Glos, UK. Edward Elgar Publishing,Inc.

Kelley, D.J., Brush, C.G., Greene, P.G., Litovsky, Y. (2014). GEM 2012 Women's Report. . Babson Park, MA, U.S.: Babson College; Santiago, Chile: Universidad del Desarrollo; Malaysia: Universiti Tun Abdul Razak; London, U.K: London School of Business and London, U.K.: Global Entrepreneurship Research Association.. Retrieved from http://www.babson.edu/Academics/centers/blank-center/globalresearch/gem/Documents/GEM\%202012\%20Womens\%20Report.pdf 
Gender GEDI Executive Report 2014. Retrieved from http:/i.dell.com/sites/doccontent/corporate/secure/en/Documents/Gender_GEDI_Executive_ Report-2014.pdf

Streefkerk, H. (1997). Gujarati Entrepreneurship - Historical Continuity against Changing Perspectives.Economic and Political Weekly. 22 February, 1997.

Gujarat Official State Portal. All About Gujarat. Retrieved on $17^{\text {th }}$ September, 2016 from http://www.gujaratindia.com/about-gujarat/why-gujarat.htm

Gujarat Micro, Small and Medium Enterprises Report - 2013. Retrieved from http:/ficci.in/state/1003/add_docs/ised-gujarat.pdf

NI-MSME Website. Retrieved from http //www.nimsme.org/

IIE Website. Retrieved from http://iie.nic.in/

NSIC website. Retrieved from http//www.nsic.co.in/SCHSERV.ASP

MSME Schemes (2016). Retrieved from

http:/nimsme.org/ranzo/uploads/articles/eBook_MSME_Schemes_English.pdf

MSME Schemes (2015).

MUDRA Scheme (2015). Retrieved from

file://C:/Users/CG/Desktop/Success\%20Stories.pdf

State Bank of Travancore Website

http:/www.statebankoftravancore.com/portal/documents/70935/94093/STAND+UP+INDIA. pdf/84125768-2542-452d-92e9-c05f8e06b359

Women and Child Development Department Newsletter, Government of Gujarat. Vibrant Gujarat 11-13 January, 2015. Retrieved from 
http:/www.vibrantgujarat.com/writereaddata/images/pdf/vg-newswire-april-May04102014.pdf

Commisionarate of WCD. Women and Child Development Department, GoG Website http:/wcd.gujarat.gov.in/CommissionerateofChildDevelopment.html

GWEDC.Women and Child Development Department Website http://wcd.gujarat.gov.in/corporation.html

Industries Commissionarate Website, GoG.http//ic.gujarat.gov.in/?page_id=3776

Gujarat Chamber of Commerce and Industries Website http:/www.gujaratchamber.org/Business-women-wing/about-bww.aspx

Gujarat Industrial Development Corporation Website https:/gidc.gujarat.gov.in/pdf/Briefabout-Women-Industrial-Park.pdf

Express News Service (2016). Gujarat 'Women Only' Industrial Park: 76 Plots Allotted to Entrepreneurs at Sanand. The India Express Article on Augst 4, 2016. Retrieved on $26^{\text {th }}$ September, 2016 from http//indianexpress.com/article/india/india-news-india/gujaratindustrial-park-gujarat-women-gujarat-women-only- ind ustrial-park-gujarat-developmentgujarat-women-development-gujarat-real-estate-gujarat-development-former-cm-anandibenpatel-2952734/ 


\section{CHAPTER - II}

\section{Review of Literature}

In pursuit of exploring 'Women Entrepreneurship', problems and prospects associated with this phenomenon with special reference to MSME in the state of Gujarat, the researcher has reviewed available literatures and has categorized it in three sections-

2.1. International evidences as per available literature

2.2. National evidences as per available literature

2.3. Gujarat based evidences as per available literature

\subsection{International Evidences}

Early literature shows a neglect of women business owners by mass media and scholarly journals. It can be supported by the Baker, Aldrich and Liou (1997) article Invisible Entrepreneurs: the neglect of women business owners by mass media and scholarly journals in USA' unleashes that there was a decline in coverage of news related to women as business owners and entrepreneurs from 1982 to 1995 by the business periodicals. In addition to this it has also been reported that although there was an increase in the coverage of women in general by entrepreneurship and management journals during 1982 to 1995 but coverage of women as entrepreneur declined significantly. Also majority i.e. 85 per cent of articles published in entrepreneurship 
journals over the period made no mention of women in either form; employee or owner. There are three explanations of this phenomenon as described in the article- (1) Media intends to cover only those news which are worth reporting according to editors or reporters and women's business is not worth considering a news; (2) Scholars while writing a research article give most importance to economically crucial entities which has not been achieved by women owned businesses because of its small size and meager economic value; (3) very few gendered differences has been documented specifically while pointing out the ownership style and practices of male and female entrepreneurs, which often gets neglected by the researchers and newspaper reporters.

Buttner and Moore (1997)in their research 'Women's Organizational Exodus to Entrepreneurship : Self Reported Motivations and Correlates with Success' scrutinize the reason 129 women executives and professional left large organizations to become entrepreneur and how they measure success, and it reveals that they did it in pursuit of challenge, self determination, to balance work with family responsibilities. They also enumerated the blocks to career growth ladder namely discrimination and organizational dynamics. Their definition of success includes key terms like self fulfillment and goal achievement which sidelines the importance of profit and business growth.

Anna, Chandler, Jansen and Mero (2000) in their empirical research 'Women Business Owners in Traditional and Non-traditional Industries' examine 170 women entrepreneurs from various traditional and non-traditional business enterprises from Utah and Illinois with designed questionnaire and with the help of in-depth interviews. Based on 'Social Learning Theory' hypotheses were framed. Analysis reveals that significant difference exist between the women entrepreneurs of traditional and non-traditional business enterprises with traditional women entrepreneurs to be higher on venture efficacy for opportunity recognition, higher career expectations of life balance and security. They, more than non-traditional women entrepreneurs, are observed to give more importance to financial support provided by others.

Coughlin and Thomas (2002) in their book 'The Rise of Women Entrepreneurs: People, Processes and Global Trends' underscores numerous evidences to present the rising phenomenon of women entrepreneurship and its impact on various developed and developing economies. This book documents the rise of women owned firms from 1987 to 1999 to be 103 per cent, rise in the employment generation by women led firms to be enhanced by 320 per cent, and an astounding growth in the annual sales to 436 per cent 
in USA. It is nearly the same time when as per previous literature media and journals neglected the mentioning of women as either employee or owner in their news coverage or research articles respectively. The book also gives a view of aspects with regard to women's life which affects her very existence like discrimination, lack of education and skills, ruthless cases of domestic violence and intimidation against woman, women share in the labor force etc. These aspects of woman's life have forced them to demand for empowerment which is strategically catered by entrepreneurship as a tool. With the help of evidences the book unleashes the deep seated motivation which drives them for entrepreneurship - economic (need to generate income), social (doing business around the needs of the family and social need of the family) and personal (to empower self for being the in-charge of one's own fate).

Aldrich and Cliff (2003) establishes in their article 'The Pervasive Effects of Family on Entrepreneurship: Toward a Family Embeddedness Perspective' that long-term changes in family composition and effective changes in roles and relations of family as an institution in North-America over the past century have implications for the emergence of new business opportunities, opportunity recognition, business start-up decisions and the resource mobilization process. The increasing number of working women in NorthAmerica seems to show interesting implications for the recognition of entrepreneurial opportunities which is both facilitating as well as inhibiting in nature. It can be facilitating in cases where women has earned enough to initiate a new venture to get rid of inequity experiences such as hitting the 'glass ceiling' and job frustration. It can be inhibiting where the women may face it difficult to find out time to launch a business as woman has to balance between their work and home related responsibilities. Hence it is presented that the increasing numbers of working women have mixed implication on the decision of venture creation. It is also observed that female spouses are a commonly tapped source of unpaid (or at least underpaid) labor during an organization's early years.

Minniti and Arenius (2003) in their seminar presentation on 'Women in Entrepreneurship' declare the GEM study report that the likelihood of starting a new business is higher among women with perceived skills and knowledge than those who perceives that they lack such skills. The study on GEM study also reports that individuals between 25 and 34 years of age are much prone to start a business thus adult women forms a readily available repository of potential entrepreneurial activity. 
Government should address factor such as education, training and family work reconciliation to create an enabling entrepreneurial environment for women.

OECD (2004) in their second conference of ministers responsible for small and medium sized enterprises (SMEs) which was organized with a theme of 'Promoting Entrepreneurship and Innovative SMEs in a Global Economy: Towards a more responsible and inclusive globalization' in Istanbul in June, 2004 which contemplated on 'Women Entrepreneurship: Issues and Policies' felt the need of discussing it from two viewpoints: (1) in the last decade women entrepreneurship has been recognized as an important untapped source of economic growth. (2) women in entrepreneurship have largely been neglected not only in general society but also in social sciences. It has been argued that women entrepreneurship should be examined both at individual level (i.e. the choice of becoming self employed) and at the enterprise level (the performance of women led enterprises). The paper also suggests: (a) supply side of entrepreneurship which belief that cultural beliefs regarding gendered perspective on career choices channels individual decision into a particular profession/occupation and women due to still existing major responsibility of family and children are more prone to start part-time businesses or start a home-based self employment activity, (b) demand side of entrepreneurship which mentions the effect of three factors which contributes to the factor of gender inequality - political and institutional framework (like occupational closure and occupational segregation will suppress women's ability to exploit various entrepreneurial opportunities), family policy and market sources. There has been discussion over the general obstacles like lack of role models in entrepreneurship, lack of experience, lack of relevant networks and societal position, lack of wealth and collateral security and finally competing demand of time which becomes an obstacle as women have unlimited responsibility on family front; and start-up specific obstacles like external finance and gender discrimination.

Carter \& Brush (2004) in their chapter 'Gender' in the 'Handbook of Entrepreneurial Dynamics', proposes a model which depicts that the generation of firm properties is a function of three factors - a) Individual assets b) Access to opportunity and c) Social networks. This model assumes that in each of the factors there will be differentiation on account of gender differences. 
a) Individual assets - Individual assets and attributes that are different in men and women and reflect differential experiences in firm emergence are categorized as -1) Human and financial Capital 2) Intentions 3) Risk propensity and 4) Family Business Background.

b) Access to opportunity - Gender and Minority Variables Group (GMVG) ${ }^{2}$ review is guided by two groups of theories i.e. discrimination theories and systematic barriers, which explain why women might have less access to resource opportunities in the environment. On one hand Discrimination theory proposes bias on part of dominant group as the source of differential treatment where either woman may face differential treatment on part of lenders because of gender biases or women may choose not to pursue formal lending agencies because of the assumption that they will face differential treatment on gender bias grounds. On the other hand systematic barriers may come into play from social, cultural and work structures and may cause the intentions of women and men to differ. Systematic barrier may lead women run enterprises to have normative expectations e.g. they may chose to locate in industries where comparatively fewer external resources are required for the completion of the process etc.

c) Social Networks - Social Networks form an imperative mechanism for the effectual gush of information and opportunities among the entrepreneurs. Researches reveal that men and women have different composition of social networks with women more focused to family and men focused to non-kin networks.

In nutshell this study postulates that if women nascent entrepreneurs carries less effective individual assets, has less access to opportunity structures along with less functional social networks, they are more prone to shut down their start-up efforts.

Brush and Manolova (2004)in their chapter 'Personal Background' in the same book describes that the most important resource nascent entrepreneurs bring with them in starting a business is their 'Human Capital' which encompasses three categories of variables - work experience, educational background and functional expertise, which have been studied in their research.

Matthews and Human (2004)in chapter 'Family Background' in the same book unleashes the significant role played by family background and role models for the

\footnotetext{
${ }^{2}$ University of Michigan conducted Panel Study of Entrepreneurial Dynamics (PSED), a study that is designed to identify the scientific understanding of how people start businesses, for which GMVG was created under the aegis of Entrepreneurship Research Consortium (ERC), the group responsible for designing the study and developing the measurement instrument, with responsibility for ensuring that the procedures and instruments adopted make use of gender and minoritylens.
} 
nascent entrepreneurs to choose self employment as their occupation. In this study the nascent entrepreneurs have been asked responses on various factors like existence of family members and/or non-family members as role models, the duration of entrepreneurial activities of their role model, size and number of those activities (e.g. size and number of family businesses), attitude towards or encouragement received from the role models. Findings of this study revealed that nascent entrepreneurs received slightly stronger motivation and encouragement for initiating business activity from family, relatives or other close friends than the comparison ${ }^{3}$ group.

Richardson, Howarth and Finnegan (2004) in their SEED working paper no. 47 titled 'The Challenges of Growing Small Businesses: Insights from Women Entrepreneurs in Africa' an action research project which was funded as an Ireland Aid's Partnership Programme with International Labour Organization (ILO) and its InFocus Programme on Boosting Employment through Small Enterprises Development (IFP/SEED), interviewed 379 women business owners to explore the critical factors impacting women enterprises, jobs and gender in Africa so that meaningful and sustainable opportunities can be framed and for poverty mitigation. This study while profiling the women entrepreneurs and their assets for businesses found much of the evidence of existence of women entrepreneurs as a result of 'push factor' as they were not left with any other choice to escape from poverty. This study also found much evidences of women entrepreneurs to be engaged in informal economy as micro-entrepreneurs, consequently making it a stereotype of women entrepreneurs as a whole in regions such as Africa. The research also label women enterprises to have following characteristics - largely informal enterprises, tend to operate from inappropriate premises, primarily micro rather than small enterprises, trading in sectors/area which are labeled as 'gendered' or feminized sectors, restricted in locally based market which are narrow in size, are undercapitalized and generate limited profits, have labor intensive businesses and makes minimal use of new technology and aims minimal growth via multiple businesses.

Aspray and Cohoon (2007) in their paper 'Gender difference in firm size, growth and persistence: A review of research literature on women's entrepreneurship in the information technology field', as part of Entrepreneurial Report Series under the auspices of National Center for Women and Information Technology, investigates -

\footnotetext{
${ }^{3}$ Comparison group in this study included control group of those who are not involved in firm creation.
} 
- Effect of intention of growth by the founder member. The smaller size of the women run businesses is the result of lower threshold women owners set on their size of business in order to lesser the chance of them losing control over their firms may be through dilution of power from equity investment.

- Highlighting the study of Oser and Hogarth-Scott 139 entrepreneurs including 33 women entrepreneurs were interviewed from 5 Canadian cities concerning their justification for to or not to follow growth strategy seven reasons have been identified playing crucial role out of which three factor were dominant for women to decide the growth strategy i.e. (i) recognition/accomplishment (ii) personal costs of growth and (iii) opinions of others. These factors play inhibiting role for women entrepreneurs to make growth strategy decisions.

Aidis, Welter, Smallbone and Isakova (2007) in their research 'Female Entrepreneurship in Transition Economies: The Case of Lithuania and Ukraine' results suggests that interaction among various economic, institutional, and transitional influences affects female entrepreneurship. Formal institutions like rules and regulations may contribute towards female business development, informal institutions such as gendered norms and values that reflect the patriarchy observed during the soviet era restrict the women from accessing resources from market and other form of entrepreneurial activity. The establishment of newly formed identities, the legacy gender relations of Soviet and the newly established international alliances (EU membership in the case of Lithuania), all have played an important role in shaping opportunities for female entrepreneurs. It can be well supported by the fact that in both Lithuania and Ukraine, women actively started helping in building the market economy by accelerated entrepreneurial activities. While women in Lithuania and Ukraine seem common on many fronts but they reflect dissimilarity like in case of Lithuania, relatively rapid growth has contributed towards increasing number of female entrepreneurs. This may seem positive effect but it also signals that large numbers of female choose the entrepreneurial way, at least initially, because of necessity.

Wube (2010)in his thesis 'Factors Affecting the Performance of Women Entrepreneurs in Micro and Small Enterprises - A Case of Dessie Town' which is based on the interviews of 197 respondents and of concerned officials summarizes that most women entrepreneurs are of the age 31-40 (40.1 per cent) with an educational background of $5^{\text {th }}$ $8^{\text {th }}$ formal schooling (29.92 per cent), an experience of 1-5 years (46.19 per cent) and are 
married (45.18 per cent).Most of the women have legal ownership establishment of their enterprise as 'Cooperatives' (75.13 per cent), majority start their businesses due to unavailability of alternatives (52.79 per cent), have no entrepreneurial family background (70.05 per cent) and main source of start-up fund is micro-finance (77.66 per cent). The economic factor which are severely effecting women entrepreneurs performance are lack of own premises or land, lack of financial access, competition in the market, inadequate access to training, lack of access to technology and raw materials. Infrastructural problems and access to information are not at all serious economic problems for these entrepreneurs. Social factors affecting women entrepreneurs in Dessie town are conflicting gender roles, social acceptability and contact network with outsiders whereas class biases, gender inequality, employee attitude towards female owners, harassment and relationship with labor does not form serious social problem. Legal/administrative problems which inhibit performance of women entrepreneurs are lack of network with administrative bodies, access to policy makers, amount of tax levied, interest rate charged, bureaucracy and red tapes. Whereas support from government bodies, government incentives, institutional and policy constraints are not as such problems. Economic factors tend to affect the performance of women entrepreneurs more, than is the effect coming from legal/administrative factors and lastly the social factors that restricts women entrepreneurs' performance in Dessie town.

Pines, Lerner and Schwartz (2010) in their research article 'Gender differences in entrepreneurship equality, diversity and inclusion in times of global crisis' endeavors to examine the implication of economic crisis for women entrepreneurship from the perspective of equality, diversity and inclusion. It studies the Global Entrepreneurship Monitor (GEM) 2007 and 2008 reports focusing on gender differences in entrepreneurship that examined the rate of entrepreneurship in 43 countries. Surprisingly study locates that woman entrepreneurship is found in those countries where the general income per capita is small and where women have no alternative option of income generation hence indicating towards greater dominance of necessity factor over opportunity factor. It also divulges that women led businesses manages to get in but faces difficulty in survival of business on the basis of revelation that gender differences are larger in established businesses over nascent businesses irrespective of economies. This analysis establishes that since many women led business are in informal sector and are extremely small in operations especially nascent businesses than established 
businesses, it is understood that because of this women entrepreneurs are unable to access financial and market resources especially in the times of economic recession. Study also emphasizes that due to this factor only many women run businesses remain unaltered due to recession and are able to survive the economic shock because of least dependence on market funds hence highlights the importance of presence of women owned businesses from economic point viewpoint.

Diaze Gracia and Welter (2011) in their paper 'Gender Identities and Practices: Interpreting Women Entrepreneurs' Narratives' draws on in-depth interviews with 19 Spanish women business owners for between one to three hours. This study divulges that women construct their identity either by building on identified dissension between womanhood and entrepreneurship, or by disproving it. Women can perceive this dissension either at the personal level or business level. Study observes that women actively manage the conflict between gendered and normative assumptions and their gendered identities by drawing on different practices i.e. doing gender and redoing gender which challenge gender differences. Two of the processes identified by Bruni et al. namely managing a dual presence in different fields with fluid boundaries and doing ceremonial and remedial work is common for all irrespective of whether identity construction is based on perceived conflicts between gender and entrepreneurship or not.

Alam, Jani and Omar (2011) in their research paper 'An Empirical Study of Success Factors of Women Entrepreneurs in Southern Region in Malaysia 'surveyed 199 women entrepreneurs out of 500 whom the self administered questionnaire were mailed and analyzes the result by applying multiple regression methodology concludes that family support, positive social ties and internal motivation factor impressively effects the success of women entrepreneurs in small businesses. ICT has no significant outcome on the success of the business as only 30 per cent of the women entrepreneurs from the surveyed population are found using web or any other ICT product because they work in small sized businesses.

Kariv (2011) in the chapter 'The Entrepreneurial Avenues' in her book 'Entrepreneurship- an International Introduction' illustrates women entrepreneur to be facing a regular gender-based difficulties while trying to establish and maintain a business. Number of factors like inflexible childcare facilities and difficulties in reconciling business and family obligations, their initial choices of industry or sector in which they want to establish the business, lack of contacts and access to goal-oriented 
networking and gender discrimination while trying to access financial support etc can be hold responsible for this. Statistical figures based on numerous academic researches establishes that female entrepreneurship is higher than male entrepreneurship among homemakers, people who transform their hobbies into businesses, those running business simultaneous or secondary to their primary employment and lastly those who start business to cater to their long cherished dreams.

Zwan, Verheul and Thurik (2012)in their empirical research 'The Entrepreneurial Ladder, Gender and Regional Development' finds that since the database included enterprises from both formal and informal sector, many women owned enterprises were covered as women has maximum spread in the informal sector of the economy. Also the merit of database was not limiting to any one rather all forms of entrepreneurial activity due to which women who are working from home on a part time basis could also be represented and their viewpoint could be counted. Variable like marital status and number of children were observed playing important part in deciding about engagement of women in a particular entrepreneurial activity. The partners work status has also been observed playing a key role in decision of women's entry into entrepreneurial activity. Even though sector decomposition is not available but an important area as women tend to be more concentrated in small scale and lower growth sectors.

OECD Council Report (2012)on 'Gender Equality in Education, Employment and Entrepreneurship' a study on OECD member countries underscores that women entrepreneurs do not seek financial credit initially because they are afraid of refusal or because they are not optimistic about their firms performance and hence profit prospects, having said that it has also been observed that the scenario is much more improved after the implementation of micro-credit in developing countries. But this is no alternate for equivalent conduct of financing petition from men and women entrepreneurs by the traditional financial institutions and banks. It beliefs important challenge to cater to boost women's entrepreneurship is insufficient solid and reliable data, hence need to collect more gender-specific data in this area. It implies that persistent discriminatory social institutions and cultural norms restrict the economic and social role of girls and women in most countries worldwide, women entrepreneurs rely less on loans both for start-ups and established firms activities in comparison to men, women owned enterprises are significantly smaller and less participative in capital-intensive sectors which penalizes them in terms of sales, profits and labor productivity, government 
should ensure that women entrepreneurship targeted policies should not only focus upon start-ups but also on expansion needs of all existing firms and most importantly comprehensive support programmes should be devised to encourage women entrepreneurs to initiate start-ups in high-tech sectors.

Acs and Szerb (2012)in 'Global Entrepreneurship and Development Index- 2012' describes that GEDI is composed of three building blocks / sub indexes i.e. the 3As entrepreneurial attitude, entrepreneurial actions and entrepreneurial aspirations. These three sub-indexes stand on 14 pillars which are in place to describe the open ended nature of entrepreneurship (irrespective of gender) and include both individual and institutional variables. These are -

1. The pillars of entrepreneurial attitude - opportunity perception, start-up skills, non fear of failure, networking and cultural support.

2. The pillars of entrepreneurial actions - opportunity start-up, tech sector, quality of human resources and competition.

3. The pillars of entrepreneurial aspirations - product innovations, process innovations, high growth, internationalization and risk capital.

Dawson and Henley (2012)conduct a conceptual study on 'Push versus Pull Entrepreneurship: An Ambiguous Distinction?' with a purpose to re-examine the dominance of 'push' or 'pull' factor when person choose to turn into an entrepreneur finds that 86 per cent pronounces single reason for choosing self employment i.e. independence. Men and women reflects different pattern of responses. In case of women although independence plays major driving force to become an entrepreneur, 22 per cent of women also chose family commitment to be one of the key factors. 'Push' accounts for as much as 48 per cent of respondents to choose entrepreneurship as an occupation. Women has majorly been observed combining 'Push' with 'Pull' factors in case there are two or more reasons to indulge into entrepreneurial activities unlike men who are observed combining 'Pull' with 'Push'.

Manzano, Martinez-Fuentes and Pardo-del-Val (2012)in their chapter 'Women Entrepreneurship and Performance' in the book Women's Entrepreneurship and Economics, aims to deepen in the discussion about gender and performance in the new firms. They used data from GEM research program to check gender differences. This concludes with the findings that women tend to center their businesses in services and 
customer-oriented services more than men. Using the term 'female ghetto' this sector is characterized by highly labour-intensive, lower in terms of growth and encountering competition more than any other industries leading to lower female performance. Female in general possess the characteristics of less optimism, lack of self-confidence and higher fear of failure. Due to lack of evidences the study is unable to establish that women start their business with less human capital (age, education etc) than men. Social acceptance of female entrepreneurship is generally increasing in most of the countries.

Rodriguez, Gonzalez-Sanchez and Rios Sastre (2012) in their chapter 'The Profiling of the European Entrepreneur: Economics and Finance, a Gender Analysis' in the book Women's Entrepreneurship and Economics says the profile of European entrepreneur is very much linked to SMEs, since they account for 99 per cent of all enterprise in the EU. Women entrepreneurs form the high potential growth group as there has been lower level of women's labour market participation than men. The distribution of entrepreneurs by economic activity sectors shows certain gender-based disparities. Service sector remains occupied by male and female entrepreneurs as mainstream. But with regards to activity sector, industry ranks second for male entrepreneurs; and agriculture for the female entrepreneurs. Research suggests female entrepreneurship gets highly affected by aversion to risk, failure to take risks and access barriers to finance.

Kamberidou (2013)in her research paper 'Women Entrepreneurs: We Cannot have Change Unless We Have Men in the Room' examines dialogues and research on female entrepreneurial activity and provide tips from successful women entrepreneurs on how new technologies can be used in different ways in social and media specifically to excel in ones carrier and balance their professional and family lives. The study wraps up with illuminating thoughts that woman of $21^{\text {st }}$ century is no longer traditional and old school types and they are actively indulged as innovative and knowledgeable part of the lot that contributes to economic growth. They are posing challenges to the traditional style of organizational culture and transforming them. By citing various researches it was proved that number women led businesses are on all time high because of mounting use of social media. The study underscores the various usages of ICT tools like social media for enhanced successful growth of women-owned businesses like find women run fora, groups and social networking sites that are in place for women since they usually offer support, connections, information and marketing opportunities are few to mention. 
Sarfaraz, Faghih and Majd (2014)in their empirical work 'The Relationship between Women Entrepreneurship and Gender Equality' attempts to answer 'How gender related economic and women entrepreneurial activity is intertwined?' Evidences in this study imply that female entrepreneurship in each country is independent of each other, has its own need to be studied and differs as per socio-economic context of individual nation. Study shows no correlation between entrepreneurial activity stage i.e. nascent entrepreneurial stage, established entrepreneurial stage or overall entrepreneurial activity, and Gender Development Index across all 41 countries under study. This study divulge that gender parity itself does not lead to more women entrepreneurship further adding that lucid comprehension of entrepreneurship as a phenomenon requires us to adopt 'multiple theoretical lenses' approach as also concluded by Landstrom and Lohrke in their study 'Historical Foundations of Entrepreneurship Research'. The study also portrays that there is a difference in availability and accessibility of female entrepreneurial opportunities in developed and developing countries all because of comparatively better gender equality in the former and more of gender inequality in later.

Goyal and Yadav (2014)in their exploratory research on 'To be or not to be a Women Entrepreneur in a Developing Country' determines the challenges faced by women entrepreneurs in developing countries which includes process difficulty in the access of finance, social-cultural biases against women and low self-esteem, existence of institutional voids and lack of skill and entrepreneurial education. By using content analysis method to evaluate shortlisted literature to unearth conceptual categories it has been resulted that although the challenges like institutional voids and lack of skill exist in case of male counterpart also but the intensity is higher in female entrepreneurs.

Kauffman Foundation article (2015) 'Challenges facing New Entrepreneurs in 2014' identifies tax-related regulations to be specific government regulation posing greatest difficulty for about 41.49 per cent new entrepreneurs out of 617 respondents. Other general challenges faced by new entrepreneurs are unpredictability of business conditions and lack of access to credit. 


\subsection{National Evidences}

Das (2001)in her work 'Women Entrepreneurs from India: Problems, Motivations and Success Factor'which is based on two states of southern India - Tamilnadu and Kerala, with an objective of profiling women owned businesses, identifying the problems they face in the start-up stage, work-family conflict if any and self reported reasons of success. Results produced shows women are majorly young 70 per cent being under 44 years of age, 90 per cent of them are married, fairly educated with 50 per cent women entrepreneurs holding university degree and only 34 per cent women had prior experience of any nature of work. Majority i.e. 54 per cent of them belong to manufacturing sector and having taken loans from bank and spouse (nearly 43 per cent). Most serious current problem is cashflow followed by marketing and employee management. Nearly 74 per cent agreed that husband is happy with their involvement in business activity and 70 per cent quoted that their husbands provided them with required emotional support. Five women entrepreneurs were observed quoting husbands support as the key factor for their success in business. Reason for 16 per cent of women entrepreneur is the challenge, trying something on one's own and independence factor, for 15 per cent the motivation seem to be the idea of keeping themselves busy, for 14 per cent of women entrepreneurs the motivation is the financial reward associated with entrepreneurial activities.

Kollan and Parikh (2005)in the working paper 'A Reflection of the Indian Women in Entrepreneurial World' narrates the evolution of women entrepreneurs in India from the era of fifties to $21^{\text {st }}$ century and identifies that how transformation has occurred in women's role. While enumerating the problems faced by women entrepreneurs in India in current scenario the problems surfaced are lack of self-confidence among women entrepreneurs, lack of working capital and socio-cultural barriers like preference to male child over female child in case of accessing formal education or any other form of training debars women from working world.

Sarvamangala (2006)in her doctoral work Institutional support system and development of women entrepreneurship in Karnataka a special focus on Bangalore District' after conducting an empirical work by surveying 100 women entrepreneurs with an objective to examine the nature of support system existing in Karnataka for 
entrepreneurs in general and women entrepreneurs in particular and comes to the conclusion that women entrepreneurs in this region are highly concerned about appropriate work-life balance. According to them increasing rates of divorce is the result of not maintaining work-life balance. Positive vibes from positive family plays important role in the performance of an entrepreneur. Many highly educated women entrepreneurs opined of discrimination in the conduct of government authorities especially at the time of allotment of tender. Even if women entrepreneur's eligibility outranks the male counterpart and the tender is allotted to her firm only 40 per cent to 50 per cent of the task is actually given to her. Women entrepreneurs conveyed of huge loss they have to incur because after giving orders many customers do not return to receive their orders. This becomes a problem when women entrepreneur has taken credit from market to complete the order. 40 per cent of women entrepreneurs who have registered their firms in DIC (District Industries Commissionarate) are not aware of different institutions which are established to extend support to them. The various bank officials informed that women do not take interest in attending the training programmes organized for their benefit.

Govindappa (2006) in her doctoral thesis 'A Study of Women Entrepreneurship in Mumbai' surveyed 120 women entrepreneurs with an objective of studying the socioeconomic background of women entrepreneurs and to identify the motivational factors for women entrepreneurs in Mumbai city, with the help of semi-structured questionnaire. A SWOT analysis of the women entrepreneurs and women run business highlights loyalty and dedication, self confidence, openness to new ideas, good contacts, readiness to face challenges, vision and foresight, effective planning and decision making and mental stamina at times of crisis as major strengths; lack of accounting skills and business management skills, intolerance, difficulty in handling crisis, indecisiveness and postponement of decisions as important weaknesses; strong family support, growth opportunity, continuous increase in demand for products, assured market, good education and qualification and urban location as major opportunities; and competition from large firms, shortage of capital, wavering or less demand, difference in quality standards, obsolescence of product technology and lack of proper assistance from government organizations as important forms of threats.

Rajani (2008)in her empirical research conducted on a sample of 100 women entrepreneurs from Kadapa district of Rayalaseema region of Andhra Pradesh to analyze 
the process and styles of management presents her results in paper 'Management Training Needs of Women Entrepreneurs'. Socio-economic and demographic profile represents that majority of women entrepreneurs are of the age group 36 and above (54 per cent), are from low income level background (51 per cent), have education less than S.S.C (50 per cent) and are married (76 per cent). A dominating figure of 56 per cent women entrepreneurs belonged to service sector. In total only 26 per cent of women entrepreneurs received skill oriented business training and only 18 per cent of women entrepreneurs in total have some kind of business experience before going on board in business. Management training are required in terms of confidence building, competence building and capital access.

Williams and Gurtoo (2011)in their empirical research 'Evaluating Women Entrepreneurs in the Informal Sector: Some Evidence from India' supports that not all entrepreneurial ventures in informal sector in marginalized population are no longer engaged in low quality work conducted under poor conditions for low pay out of necessity in absence of alternative means of livelihood. By conducting face to face interviews of about 323 women entrepreneurs working in informal sector of India it was deduced that although the structuralist representation is largely appropriate for women involved in wage form in informal sector, it is invalid for women entrepreneurs in this sector working on self employed basis, because in their cases the income is comparatively higher than those working as wage worker, they receive more cred it from informal institutions, enjoys higher union membership and hence such work become much rational choice over necessity based or being a choice as last resort.

Dwivedi and Dwivedi (2011) in their paper 'Women-Empowerment through Women Entrepreneurship (A study of Faizabad Zone of Uttar-Pradesh)' by interviewing 17 women entrepreneurs basically beauty salon of Faizabad, UP (India), makes effort to analyze the economic contribution of women entrepreneur run businesses and problems they face. Result of this study portrays that beauty salon as a business is most convenient for home based entrepreneurs to start and get economic benefit. There lies strong correlation between age and average initial investment, age and return on investment and average initial investment and rate of return.

Narendran (2011)in her research work 'Are the Female Entrepreneurs of Beauty Salon in India, Victims of Bad Publicity?' as a result of empirical survey conducted in Thiruvananthpuram city of Kerala, a south-west state in India, on 151 women 
entrepreneurs where the findings with regard to the spread of women run businesses disclosed the interest of majority of women entrepreneurs to start business in femaleoriented sectors for example manufacturing of food products (catering, 30.5 per cent), the manufacturing of wearing apparel (tailoring, 27.8 per cent) and carrying out beauty treatments (beauty parlours, 8.6 per cent).

Waghmare (2012) in his book 'Women Entrepreneurship' studies the problems and prospects of women entrepreneurs of Sangli, a district of Maharashtra (India). This study made an effort to identify the problems of women entrepreneurs under the categories of personal problems, social problems, marketing problems, human resource problems, managerial problems, infrastructural problems, occupational mobility problems and government support problems. It was concluded that women entrepreneur in Sangli district of Maharashtra mostly (75.3 per cent) faces financial problems over other problems as categorized.

Berland (2012) conducted online interviews with 150 women entrepreneurs in India and incorporated his conclusions in 'Dell Women's Global Entrepreneurship Study: India Key Finding'. The report suggests that women business owners in India are much confident and believe 90 per cent of business growth in next five years, 71 per cent say that their business is very successful, 8 out of every 10 women entrepreneurs say that they are hiring, 74 per cent say their technology needs are getting complex, 90 per cent women entrepreneurs started their business alongside managing their day jobs and 41 per cent of women entrepreneurs look to their spouses for advices. On technology front 9 in 10 say that technology supports their day to day operations. 46 per cent of women entrepreneurs agree to source their seed capital from personal savings followed by family members (43 per cent), bank credit (33 per cent), friends (25 per cent) and business acquaintances (21 per cent). Banks or credit union becomes most difficult sources to obtain funding.

Ghani, Kerr \& O'Connell (2013) in their paper financed by World Bank, 'Political Reservations and Women's entrepreneurship in India', portrays the potential interlinking between the factor of State level implementations of political reservations for women in India and the effect on the role of women on the manufacturing sector of India. The study makes use of data for unorganized sector surveyed by National Sample Survey Organization (NSSO) conducted in the fiscal year 1994, 2000 and 2004. For the data pertaining to organized sector the study procures data from Annual Survey of Industries 
(ASI) for the similar fiscal years as NSSO. The study successfully establishes the interlink between the political reservation of women with that of economic empowerment of women with evidences that women owned establishments have heightened in unorganized sector after the implementation of political reservation of women. This study finally interprets that the reform has motivated women in general to start a business venture at a small scale in those fields in which they have been working traditionally like a home-based business venture.

Kumar, Mohan, Vijaya and Lokeshwari (2013) in their work 'The Role of Women Entrepreneurship in Modern World' suggests that women are most likely to chose entrepreneurship in retail trade, restaurants, hotels, education, cultural, cosmetics, health insurance and manufacturing. Successful women entrepreneurs play instrumental role in motivating women to choose entrepreneurship as an occupation. Other motivational factors for women entrepreneurs to choose entrepreneurship as an occupational career are desire to improve quality of life for their children, share family's economic responsibility, managing work with personal responsibilities on family front or sudden demise of spouse.

Sharma (2013) finds in her extensive literature review for her paper 'Women Entrepreneur in India' that the major problems faced by women entrepreneurs are family ties, social barriers, lack of education, male dominated society, shortage of raw materials, access of finance, tough competition, high cost of production, low risk bearing capacity, limited mobility, lack of entrepreneurial aptitude, limited managerial ability, legal formalities, exploitation by middle man and lack of self-confidence.

IFC (2014) in a research finding 'Micro, Small and Medium Enterprises-Improving Access to finance for Women-owned Businesses in India' reveals that 78 per cent of women entrepreneurs in India belong to service sector, 98 per cent of them are into micro enterprises. For these women entrepreneurs' major barrier to perform at par with successful businesses is lack of access to formal finance as 90 per cent of the $\mathrm{m}$ agree that their need of finances is catered through informal sources. Total finance requirement for women owned enterprises was about Rs. 8.68 trillion in 2012 out of which small enterprises demand accounted for Rs. 6.42 trillion (74 per cent), micro enterprises demand accounted for Rs. 2.05 trillion (24 per cent) and medium enterprises demand of 
finance accounted for Rs. 0.21 trillion (2 per cent). Against this huge demand a total supply of finance, for women entrepreneurs in India, was Rs. 2.31 trillion hence 73 per cent of the total demand remained unmet by the MSME women entrepreneurs. This calls for instant interference by policy makers and government institutions to bring troubleshoot to this situation.

Veena (2014) in her doctoral study 'Managerial Performance of Women Entrepreneurs in Mysore District' reveals that about one fourth of the women entrepreneurs have participated in Entrepreneurship Development Programme (EDPs) for entering into entrepreneurial activity. In all 44 per cent of entrepreneurs have asked for assistance of specialized agencies which are external to their family for preparing themselves to venture into enterprising world. Decision of entering into entrepreneurial occupation did not come as a byproduct of family income, educational qualifications and presence of working mother as a role model. Mostly those who have required professional/vocational qualifications observed entry into entrepreneurship as an occupation. Psychological motives (fulfillment of self-actualization needs) and economic motives (to seek improved standard of living) form the basic reason to choose entrepreneurship. Women entrepreneurs consider themselves to possess high level self-confidence, the ability to establish and run their enterprises which can be seen due to professional/vocationally trained, family income, educational performance and work experience.

\subsection{Gujarat Based Evidences}

Patel (2005) in her doctoral work 'Growth of Women Entrepreneurship in Baroda' carried out a survey and identified that many registered units under the name of women entrepreneurs were actually proxy units being run and mainly handled by male owners. Female owners name was found to be associated at the time of registration with a so le motive of being able to enjoy women related benefits under different government schemes. Survey report of 200 women entrepreneurs with the help of NGO's and actual registered units under DIC the results revealed that majority women entrepreneurs in Baroda, a city in Gujarat are young and hence full time to see their business grow, have 
literate fathers with majorly having graduate degree, have literate mothers as well but the level of education is comparatively lower than that of fathers, earn very less from entrepreneurial venture and only very few of them are able to earn a decent income from the entrepreneurial venture, majority have nil or a meager saving out of their income, own business as proprietor majorly and very few have an establishment on partnership basis, adopt manual technology to run their business processes and observed having employed no employees for their business activities as the scale of the business is micro. The facilitating factors encouraging them to pursue entrepreneurship included success stories of other women entrepreneurs, previous association or past experience in the same field, and advice from family, friends or relatives.

Roy (2005) writes in his article 'Deepali has Designs on You' in Business Standard describing the success story of Deepali Jahanara, Ahmedabad based fashion designer who won 'Women Entrepreneur Award' by Shri Narendra Modi, the then Chief Minister of Gujarat. Deepali owns 'Jahanara Fashion Studio' known for bridal wear designing across Gujarat and overseas. She started her career with Rs. 1,500 in Ahmedabad in the year 2004. According to her designing outfits has always been in her passion. She stitched her first cloth in the standard VI. For her choosing fashion designing as a carrier and becoming an entrepreneur is driven due to her instinctive passion (pull factor). She attributes her success to her fashion journalist, business partner turned husband. He expresses ideas on recent trends and fashion and manages finances in the business. 40-50 workers work under her. Deepali is also harnessing technology to expand her business.

Roy (2005) in his article 'Knotting Her Way to Success' in Business Standard narrates the success story of one more 'Women Entrepreneur Awardee' Chandrika Bhayani who has strong hold in Saurashtra market for creating bandhni textiles. Her business, 'Utsav Creation' in Jamnagar, currently has a turnover of Rs. 12 Lakh. Bhayani is having not so impressive educational qualification till standard $\mathrm{X}$, but has a superfluously impressive business skill all because of initiative and dedication. According to her, currently 25 workers work in her factory outlet 90 per cent of which are women mostly middle-aged. She started her business in 1999 due to her husband incurring loss in his business (push factor). Her initial investment to this business was a meager amount of Rs. 1 Lakh. Today her business has wide reach to Mumbai, Ahmedabad, Vadodara and Jamnagar. According to her government should have such measures which help these bandhani based business owners to take their businesses to international markets. 
Samani (2008) in her doctoral work 'A Study of Women Entrepreneurs Engaged in Food Processing' surveyed 300 women entrepreneurs belonging to food processing business activities based in Rajkot city of Gujarat with an objective of understanding their socioeconomic background, the problems they face and the various motivating factors to choose entrepreneurship. The result reveals that very few of these women entrepreneurs undergone any kind of formal training, more than 50 per cent of women entrepreneurs wanted to avail the facility of loan to meet with various expenditure needs but could not succeed, most of them did not obtain license to work in this industry, made sincere efforts to maintain health and hygiene while processing food items and most women faced problems in co-operation.

Sinha (2013) in her work 'Women Entrepreneurship with special reference to SRIMCA, Bardoli, Gujarat' on a survey which was conducted on 60 female students of Management of Shrimad Rajchandra Institute of Management and Computer Application (SRIMCA) which is located in Bardoli-Mahuva Road of Tarsadi, Dist Surat, identified that the young MBA pursuant are very fairly inclined to pursue entrepreneurship as an occupation but are skeptic about the discrimination for women prevailing in Indian Society. The various motivating factors for this are believe on ones skills and attitudes (38.3 per cent), to earn more money (28.3 per cent) and their education (20 per cent). De-motivating factor unearthed in this study are lack of awareness (33.3 per cent), existence of gender discrimination in society (28.3 per cent) and disturbance in work-life balance (25 per cent). If there is an entrepreneur already in the family, the girls of such families possess the national and state level schemes/aids available to assist women in their entrepreneurial venture.

Shastri and Rao (2014) in their exploratory research paper 'Women Entrepreneurs of Gujarat' which was presented in Symbiosis Institute of Management Studies Annual Research Conference (SIMSARC13) aims to locate the social change woman has observed after entering into the orbit of entrepreneurship and with the help of few existing examples it is found that the organizations organized by women entrepreneurs brings change to the society in a positive way. In 1979 Lijjat in collaboration with UNICEF organizes a seminar on 'Child Care and Women Welfare' as part of International year of Child Celebration. In 1984 Bhadraben Bhatt represented Lijjat at UNESCO sponsored international workshop on 'The Role of Women in the Assimilation and spread of Technological Innovation' held at NITIE, Powai. With the case studies of 
Lijjat Papad, Jasuben's Pizza and the Riverside School, women entrepreneurship potential of Gujarat based women has been portrayed.

Dave (2014) in 'Women Entrepreneurship Development Special Reference to Ahmedabad City' a doctoral study which is based in Ahmedabad, a city in Gujarat, reveals as finding of a survey of 50 women entrepreneurs that major problems women entrepreneurs face is pre-establishment of the business where acquiring funds, selecting desired location and in accessing the needed information. When business is ongoing, women entrepreneurs face the problems because of lack of education and training, problems during selection of appropriate machinery, labor union problems and distribution of departmental work. On social front while running the business women face problems of dual responsibilities, strong competition, selling of product, fair price and insufficient working capital. 83 per cent of women entrepreneurs agreed that they face problems in marketing their product, 38 per cent finds price competition difficult and 27.5 per cent women entrepreneurs find the market competition tough. While trying to identify the motivation for them to choose entrepreneurship they responded selfwillingness and regular advice from family becomes motivation to them to perform in business while the least important motivating factors are other (not known) and advice from government officials. 92per cent of women entrepreneurs report that they did not get any assistance from government while 8 per cent of them received help from government with regard to finance, training, project report guidance, license, guidance for raw materials and machinery.

Balani (2014) in her blog post 'They are Undeterred \& Strong. They are the Rural Women Entrepreneurs of Gujarat' on 'Milaap' tells another story which clearly portrays the industrious aspect of women entrepreneurs of Gujarat. Describes the win of women entrepreneurs of Gujarat to succeed in what they do in form of business even after facing struggleful life. Struggle has never deterred them to pursue their business dreams rather have made them much more determined to establish a stable livelihood in order to provide a better and brighter future to their children. The story narrated by her as Milaap Fellow is of Ritu Yadav, a woman of great strength and entrepreneurial qualities from Chandkhda, an area in Ahmedbad region of Gujarat. She is into artificial jewelry business, selling the local 'Bagasra' jewelry. On personal front the matter of botheration is continuous ill health of her father-in-law which keeps her tensed, but with her compassionate nature and family management skills she is successfully able to manage 
her family along with running her business successfully. She is able to save Rs. 4000 on monthly basis and wants to add clothing apparels in her collection. For her the motivation to be in business is the desire to provide decent education and living standard to her children.

Junare and Singh (2016) in their empirical work 'Technological Understanding and Usage vis-à-vis Knowledge of Government Scheme - A Study of Women Entrepreneurs of Selected Cities of Gujarat' where 50 women entrepreneurs of Ahmedabad and Vadodara have been surveyed to probe the uncultivated facets of women entrepreneurs and trying to gather response on research question "whether there lies a relationship between technological aspects (technological skill, knowledge of modern technology and usage of technology) of women entrepreneurs with that of their knowledge of government support schemes?' Findings suggest that 56 per cent of women entrepreneurs believe that they possess sound knowledge of modern technology; only 22 per cent believe that they do not use technology in their day to day business processing and remaining 78 per cent accepts to use technology for their day to day business processing. Further it was represented that 68 per cent of those women entrepreneurs who have poor understanding of technology had poor knowledge of government schemes, those who believe to posses sound technological skills also believed to possess sound knowledge of government schemes.

Junare and Singh (2016) in their work 'An Analysis of Technological Practice among Women Entrepreneurs of different Entrepreneurial Avenues in Selected Cities of Gujarat' on basis of survey conducted on 50 women entrepreneurs of Ahmedabad and Vadodara, cities of Gujarat tries to probe the entrepreneurial avenues they chose to practice their entrepreneurial skills. The result suggests that women are mostly into the business of manufacturing of customized clothing (22 per cent) followed by retail business (16 per cent) and engineering based and handicraft businesses (10 per cent each). 


\subsection{Research Gap}

Available literature irrespective of international experiences, national experiences or state level experiences furnish a fair understanding of 'Women Entrepreneurship' as a phenomenon. It unleashes the various independent variables molding the performance of women entrepreneurs and which becomes a crucial driving force for women to prefer entrepreneurship in a given psycho-social background or poses problems to perform their role in the given scenario.

The researcher is keen to probe the problems and prospects of women entrepreneurs of the state of Gujarat. Admittedly, there are not many literatures available which focuses upon the status of women entrepreneurs of Gujarat. Scarce number of $\mathrm{PhD}$ works, research papers and other articles have ventured in this sphere of study in the state of Gujarat, but serving their purpose by conducting a case study on a state based women owned businesses/business women (e.g. Roy, 2005, Balani, 2014 and Shastri and Rao, 2014), a city specific study (e.g. Patel, 2005, Sinha, 2013, Dave, 2014 and Junare and Singh, 2016), factor specific study on women entrepreneurs of Gujarat (e.g. Junare and Singh) or an industry specific study (e.g. Samani, 2008).

Therefore it has been identified that though several studies have been conducted and enormous reviews of literature are available on the subject of MSMEs and entrepreneurship, but there are negligible researches available on the subject that covers the problems and prospects of women entrepreneurship with special reference to MSMEs especially in the state of Gujarat. Literature are lacking in conveying the demographic detail of women entrepreneurs, background of women entrepreneurs, the reason of choosing entrepreneurship as an occupation, spread of women owned enterprises in micro, small and medium enterprises, percentages of women entrepreneurs undergone EDP, effect of EDP on their business venture, enabling factors for women during the process of entrepreneurship, the various problems face by women pertaining to financial, personal, social, raw material related, marketing, labor, managerial skills, infrastructure, technology and government support. Literature fall less to even throw light upon the prospects women entrepreneurs have in the current environment for them as well as for prospective women entrepreneurs. 
The current study becomes unique in terms of probing gaps identified in the available literatures for instance lack of information about spread of women entrepreneurs among micro, small and medium enterprises, types of business activities that has inclination of women entrepreneurs in the state, status of effectiveness of EDP training to the women entrepreneurs in the state, information about enabling factors for gujarati women entrepreneurs, women specific and general problems pertaining to women entrepreneurs, various prospective factors which contributes to the upliftment of women entrepreneurs status in the state and prospective industries that welcomes women entrepreneurs to establish new and innovative ventures.

\section{References}

Baker, T., Aldrich, H.E., and Liou, N. (1997). Invisible Entrepreneurs: the neglect of women business owners by mass media and scholarly journals in USA. Entrepreneurship and Regional Development- An International Journal.(pp.221-238). 9 (3).

Buttner, E. and Moore, D. (1997). Women's Organizational exodus to Entrepreneurship: Self-Reported Motivations and Correlates with Success. Journal of Small Business Management 35(1) (pp.34-47). Retrieved from http//search.proquest.com/openview/7976a4b f8b53be57490ad225b9e2beb3/1?pqorigsite $=$ gscholar

Anna, A.L., Chandler, G.N., Jansen, E. and Mero, N.P. (2000).Women Business Owners in Traditional and Non-Traditional Industries.Journal of Business Venturing. 15 (3) . (pp. 279-303). DOI: 10.1016/S0883-9026(98)00012-3. Retrieved from http//www.sciencedirect.com/science/article/pii/S0883902698000123

Coughlin, J.H. and Thomas, A.R. (2002). The Rise of Women Entrepreneurs: People, Process and Global Trends ( $1^{\text {st }}$ Ed). Connecticut, London: Quorum Books. Retrieved from http:/www.untagsmd.ac.id/files/Perpustakaan_Digital_1/ENTREPRENEURSHIP\%20The\%20rise\%20of\% 
20women\%20entrepreneurs\%20\%20people,\%20processes,\%20and\%20global\%20trends.p df

Aldrich, H.E. and Cliff, J.E. (2003). The Pervasive Effects of Family on Entrepreneurship: Toward a Family Embeddedness Perspective. Journal of Business Venturing.18 (5). (pp573-596).

Minniti, M. and Arenius, P. (2003).Women in Entrepreneurship.Presented at the Symposium of 'The Entrepreneurial Advantage of Nations', First Annual Global Entrepreneurship Symposium on $29^{\text {th }}$ April, 2003. New York: United Nations Headquarters. Retrieved from http//citeseerx. ist.psu. edu/viewdoc/download?doi=10.1.1.471.7819\&rep=rep1\&type=pdf

OECD (2004). Women Entrepreneurship : Issues and Policies. $2^{\text {nd }}$ OECD conference of ministers responsible for small and medium sized enterprises (SMEs). 3-5 June, 2004. Istanbul, Turkey. Retrieved from http:/www.oecd.org/cfe/smes/31919215.pdf

Carter, N. M. \& Brush, C. G. (2004).Gender.Gartner, W. B., Shaver, K. G., Carter, N. M \& Reynolds, P. D. (Eds). Handbook of Entrepreneurial Dynamics- The Process of Business Creation.(pp.12-25). Thousand Oaks: California. Sage Publications.

Brush, C.G. and Manolova, T.S. (2004).Personal Background.Gartner, W. B., Shaver, K. G., Carter, N. M \& Reynolds, P. D. (Eds). Handbook of Entrepreneurial Dynamics- The Process of Business Creation.(pp.78-93). Thousand Oaks: California. Sage Publications.

Matthews, C.H. and Human, S.E. (2004).Family Background.Gartner, W. B., Shaver, K. G., Carter, N. M \& Reynolds, P. D. (Eds). Handbook of Entrepreneurial Dynamics- The Process of Business Creation.(pp.94-103). Thousand Oaks: California. Sage Publications

Richardson, P., Howarth, R. and Finnegan, G. (2004) The challenges of growing small businesses: insights from women entrepreneurs in Africa. Geneva: ILO: IFP/SEED Working Paper No. 47, Series on Women's Entrepreneurship Development and Gender Equality (WEDGE). Retrieved from http:/natlex.ilo.ch/wcmsp5/groups/public/--ed_emp/---emp_ent/documents/publication/wcms_111395.pdf 
Aspray, W. and Cohoon, J.M. (2007). Gender difference in firm size, growth and persistence: A review of research literature on women's entrepreneurship in the information technology field. Entrepreneurial Report Series under the auspices of National Center for Women and Information Technology. Retrieved from https://www.ncwit.org/sites/default/files/resources/1_entrepreneurialgrowth.pdf

Aidis, R., Welter, F., Smallbone, D., \& Isakova, N. (2007). Female entrepreneurship in transition economies: the case of Lithuania and Ukraine.Feminist Economics. 13(2), 157183. DOI: 10.1080/13545700601184831. Retrieved from http:/www.w-t-w.org/en/wpcontent/uploads/2014/03/women-entrepreneurs-in-ukraine.pdf

Wube, M.C. (2010). Factors Affecting the Performance of Women Entrepreneurs in Micro and Small Enterprises - A Case of Dessie Town.Thesis for Degree of Master of Arts in Technical and Vocational Education Management.Bahir Dar University. Retrieved from http//www. unevoc.unesco.org/e-forum/thesis\%20final.pdf

Pines, A.M., Lerner, M. and Schwartz, D.(2010). Gender differences in entrepreneurship equality, diversity and inclusion in times of global crisis. Equality, Diversity and Inclusion: An International Journal. 29 (2).pp(186-198). DOI 10.1108/02610151011024493.Emerald Publications. Also available on www.emeraldinsight.com/2040-7149.htm

Diaze Gracia, M. and Welter, F. (2011). 'Gender Identities and Practices: Interpreting Women Entrepreneurs' Narratives'. International Small Business Journal.31(4). (pp.384404). DOI: 10.1177/0266242611422829. Sage Publications. Also available on isb.sagepub.com

Alam, S.S., Jani, M.F.M., Omar, N.A. (2011). An Empirical Study of Success Factors of Women Entrepreneurs in Southern Region in Malaysia.International Journal of Economic and Finance.3(2). (pp. 166-175). doi:10.5539/ijef.v3n2p166. Retrieved from http//citeseerx. ist.psu. edu/viewdoc/download?doi=10.1.1.832.6751\&rep=rep1\&type=pdf 
Kariv, D. (2011). Entrepreneurship - An International Introduction. (1st ed.). Oxon, UK: Routledge.

Zwan, P., Verheul, I. and Thurik, A.R. (2012).The Entrepreneurial Ladder, Gender and Regional Development.Small Business Economics.39 (3). (pp.627-643). DOI:

10.1007/s11187-011-9334-7. Retrieved from

http•/link.springer.com/article/10.1007/s11187-011-9334-7

OECD Council Report (2012). Gender Equality in Education, Employment and Entrepreneurship. Paris: Final Report to the MCM 2012 Meeting of the OECD Council at Ministerial Level. 23-24 May 2012

Acs, Z.J. and Szerb, L. (2012). Global Entrepreneurship \& Development Index - 2012. Cheltenham, UK: Edward Elgar.

Dawson, C. Henley, A. (2012).“Push” versus "Pull” Entrepreneurship: An Ambiguous Distinction?.International Journal of Entrepreneurial Behavior \& Research.18 (6).(pp.697 - 719). Emerald Group. Retrieved from

http //www.emeraldinsight.com/doi/abs/10.1108/13552551211268139

Aldas-Manzano, J., Martinez-Fuentes, C. and Pardo-del-Val, M. (2012).Women Entrepreneurship and Performance.Galindo, M. and Ribeiro, D. (Eds).Women's Entrepreneurship and Economics - New Perspectives, Practices and Policies. (pp.89-108). NY, USA: Springer.

Rodriguez, F.R., Gonzalez-Sanchez, V.M. and Rios Sastre, S. (2012). The Profile of the European Entrepreneur: Economics and Finance, a Gender Analysis. Galindo, M. and Ribeiro, D. (Eds).Women's Entrepreneurship and Economics - New Perspectives, Practices and Policies. (pp.143-165). NY, USA: Springer.

Kamberidou, I. (2013). Women Entrepreneurs: We cannot have Change Unless We Have Men in the Room. Journal of Innovation and Entrepreneurship, A Springer Open Journal. 2(6). Retrieved from http://innovationentrepreneurship.springeropen.com/articles/10.1186/2192-5372-2-6 
Sarfaraz, L., Faghih, N. and Majd, A.A. (2014).The relationship between women entrepreneurship and gender equality.Journal of Global Entrepreneurship Research.2(6). DOI:10.1186/2251-7316-2-6. Retrieved from http:/www.journal-jger.com/content/2/1/6

Goyal, P., and Yadav, V. (2014).To be or not to be a Woman Entrepreneur in a Developing Country?Psychosociological Issues in Human Resource Management.2 (2). (pp. 68-78). Retrieved from https://www.researchgate.net/profile/Vanita_Yadav2/publication/271520855_TO_BE_OR _NOT_TO_BE_A_WOMAN_ENTREPRENEUR_IN_A_DEVELOPING_COUNTRY/lin ks/54cb2eaa0cf2c70ce52511fd.pdf

Kauffman (2015).Challenges facing New Entrepreneurs in 2014.The Kauffman Foundation and LegalZoom Report. Retrieved from http //www.kauffman.org/ /media/kauffman_org/research\%20reports\%20and\%20covers/2 015/02/challenges_facing_new_entrepreneurs_in_2014.pdf

Das, M. (2000-01). Women Entrepreneurs from India: Problems, Motivations and Success Factors. Journal of Small Business \& Entrepreneurship.15(4). Retrieved from http $/ /$ www.academia.edu/18877569/Women_entrepreneurs_from_India

Kollan, B., \& Parikh, I. J. (2005). A Reflection of the Indian Women in Entrepreneurial World.Pg. 12.Working Paper (Research and Publication, IIM-A, India) W.P. No. 2005-0807, August 2005. Retrieved from http://www.iimahd.ernet.in/publications/data/2005-0807indirap.pdf

Sarvamangala, R. (2006). Institutional support system and development of women entrepreneurship in Karnataka a special focus on Bangalore District. $\mathrm{PhD}$ Thesis.Kuvempu University. Shodhganga Repository. Retrieved from http:/shodhganga.inflibnet.ac.in/handle/10603/85447

Govindappa, R. (2006). A Study of Women Entrepreneurship in Mumbai.PhD Thesis.SNDT Womens University. Shodhganga Repository. Retrieved from http^//shodhganga.inflibnet.ac.in/handle/10603/109690 
Rajani, N. (2008). Management Training Needs of Women Entrepreneurs.

Anthropologist.10(4). (pp. 277-281).

Williams, and Gurtoo, (2011). Evaluating Women Entrepreneurs in the Informal Sector: Some Evidence from India.Journal of Developmental Entrepreneurship.16(03). (pp. 351369). Retrieved from

http //www.worldscientific.com/doi/pdf/10.1142/S1084946711001914

Dwivedi, A.K. and Dwivedi, N. (2011).Women-Empowerment through Women Entrepreneurship (A Study of Faizabad Zone of Uttar-Pradesh).Retrieved from SSRN: https://ssrn.com/abstract=1886250 orhttp://dx.doi.org/10.2139/ssrn.1886250

Narendran, R. (2011). Are the female entrepreneurs of beauty salons in India, victims of bad publicity?.International Journal of Diversity in Organisations, Communities and Nations.11 (1). (pp 47-56). Retrieved from http//citeseerx. ist.psu. edu/viewdoc/download?doi=10.1.1.304.5607\&rep=rep1\&type=pdf

Waghmare, A.B. (2012). Women Entrepreneurship. $1^{\text {st }}$ Ed. Himalaya Publishing House. Delhi:India

Berland, P.S. (2012). Dell Women's Global Entrepreneurship Study: India Key Findings. A Dell Study. Retrieved from http//i.dell.com/sites/content/business/smb/merchandizing/en/Documents/India-ResearchResults-Fact-Sheet.pdf

Ghani, E, Kerr, W. R \& O'Connell, S D.(2013). Political Reservations and Women's Entrepreneurship in India. Policy Research Working Paper; No. 6307. World Bank, Washington, DC. (C) World Bank. Retrieved from https://openknowledge.worldbank.org/handle/10986/12190 License: CC BY 3.0 IGO.

Kumar, S.M., Mohan, H.S.C., Vijaya, C. and Lokeshwari, N. (2013).The Role of Women Entrepreneurship in Modern World.International Journal of Current Engineering and Technology.Special Issue (1). Available at http://inpressco.com/category/ijcet 
Sharma, Y. (2013). Women Entrepreneur in India.IOSR Journal of Business and Management.15 (3). (pp. 09-14). Retrieved from http:/www.iosrjournals.org/iosrjbm/papers/Vol15-issue3/C01530914.pdf

IFC (2014).Micro, Small and Medium Enterprises- Improving Access to finance for Women-owned Businesses in India.IFC and World Bank Report. Retrieved from http//www.ifc.org/wps/wcm/connect/a17915804336f2c29b1dff384c61d9f7/Womenowne dbusiness1.pdf?MOD=AJPERES

Veena, M. (2014).Managerial Performance of Women Entrepreneurs in Mysore District.PhD Thesis.University of Mysore. Shodhganga Repository. Retrieved from http:/shodhganga.inflibnet.ac.in/handle/10603/92699

Patel, J.R..(2005). Growth of Women Entrepreneurship in Baroda.PhD Thesis.Maharaja Sayajirao University. Shodhganga Repository. Retrieved from http //shodhganga.inflibnet.ac.in/handle/10603/57921

Roy, M. (14 ${ }^{\text {th }}$ May, 2005). Deepali has Designs on You. Business Standard. Retrieved on

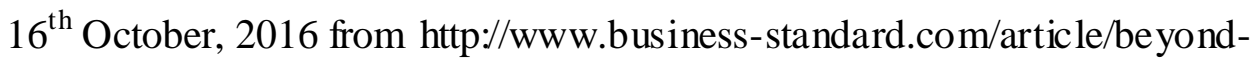
business/deepali-has-designs-on-you-105051401057_1.html

Roy, M. (23 ${ }^{\text {rd }}$ May, 2005). Knotting Her Way to Success.Business Standard. Retrieved on

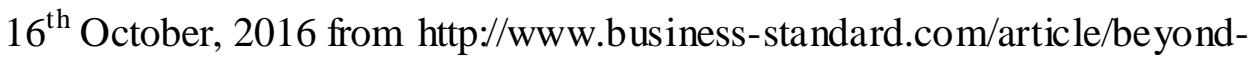
business/knotting-her-way-to-success-105052301049_1.html

Samani, V. (2008). A Study of Women Entrepreneurs Engaged in Food Processing. PhD Thesis.Saurashtra University. Retrieved from http//etheses. saurashtrauniversity.edu/id/eprint/721

Sinha, E. (2013). Women Entrepreneurship with Special Reference to Bardoli, Gujarat.ANVESHAN, IMR's Management Research Journal.3(1). (pp - 30-35). Retrieved from SSRN: https://ssrn.com/abstract=2329842 
Shastri, D and Rao, T.V. (2014).Women Entrepreneurs in Gujarat.Procedia Economics and Finance.11(2014). (pp.745-752). Retrieved from http//www.sciencedirect.com/science/article/pii/S221256711400238X\#bib0010

Dave, V.D. (2014). Women Entrepreneurship development Special Reference to Ahmedabad City.PhD Thesis.Sardar Patel University. Shodhganga Repository. Retrieved from http^/shodhganga.inflibnet.ac.in/handle/10603/43334

Balani, K. (28 ${ }^{\text {th }}$ August, 2014). They are Undeterred \& Strong. They are the Rural Women Entrepreneurs of Gujarat. [Blogpost]. Retrieved on $16^{\text {th }}$ October, 2016 from http:/blog.milaap.org/undeterred-strong-rural-women-entrepreneurs-gujarat/\#comments

Junare, S.O. and Singh, R. (2016).Technological Understanding and Usage vis-à-vis Knowledge of Government Scheme - A Study of Women Entrepreneurs of Selected Cities of Gujarat.Amity Journal of Entrepreneurship.1(1). (pp. 71-85). Retrieved from http:/amity.edu/UserFiles/admaa/104Paper\%205.pdf

Junare, S.O. and Singh, R. (2016). An Analysis of Technological Practice among Women Entrepreneurs of different Entrepreneurial Avenues in Selected Cities of Gujarat. Proceedings of $53^{\text {rd }}$ IRF International Conference, $24^{\text {th }}$ April, 2016, Pune, India. Retrived from http//iraj.in/up_proc/pdf/223-146174102481-89.pdf 


\section{CHAPTER - III}

\section{Research Methodology}

Women entrepreneurship globally and in India as well has long remained a neglected area of study. In recent times milieu of economic turmoil worldwide centered researcher's attention to women entrepreneurship and established the fact of them being an important economic agent. Theoretically (Bahmani, Sotos \& Gracia, 2012) researchers started looking into various aspects of this field of study only in 1980's. Women entrepreneurship, as a field of study, is further going to witness high investigation as it has been observed as an instrumental tool for regional balance and employment. Although businesses owned by women have shown contributing results yet women entrepreneurs continue to witness differences on various fronts like in accessing finance, accessing market resources, marketing skills, family-work balance and access to training programs are few to mention. When 'Entrepreneurship' is the agenda of discussion, Gujarat has been a special state of interest in India because of its rich entrepreneurial background. Theoretical evidences pull researchers interest to enquire whether women entrepreneurs in Gujarat have different or similar experiences with regard to problems and prospects. Therefore the researcher conducts a study focusing on enquiry of problems and prospects of women entrepreneurship in MSME sector in the state of Gujarat with following objectives. This chapter also details the hypothesis framed, scope of study, sampling method followed, data collection method adopted, statistical tools of analysis utilized and scheme of chapterization decided for the purpose successful completion of this study. 


\subsection{Objectives}

On the basis of extensive reading author has identified objectives of study as under:-

a) To study the evolution and development of entrepreneurship in India and Gujarat with special reference to women entrepreneurship.

b) To recognize the spread of women run businesses amongst Micro, Small and Medium Enterprises.

c) To extract respondents perception on prospects for women entrepreneurs in Gujarat as a market and culture.

d) To find out various enabling and limiting factors for women entrepreneurs to start-up and sustain in a business.

e) To suggest remedial measures for development of women entrepreneurship in Gujarat.

\subsection{Hypothesis}

$\mathbf{H 1} \mathbf{1}_{\mathbf{0}}$ - Size of the business and age of women entrepreneurs are independent.

$\mathbf{H} \mathbf{2}_{\mathbf{0}}$ - Size of the business and education level of women entrepreneurs are independent.

H3 0 - Size of the business and husband's occupation of women entrepreneurs are independent.

H4 $4_{0}$ - A belief of 'Education' as an enabling factor is independent of Lack of Technological Skills as a problem in women entrepreneurs.

H5 - Dual role problem for women entrepreneurs is independent of their age as an effectual variable.

H6 - Poor knowledge of Government Schemes is independent of ignorance towards banking procedures and formalities among women entrepreneurs in the state.

$\mathbf{H 7} 7_{\mathbf{0}}$ - Ignorance towards banking procedures and formalities is independent of age of women entrepreneurs as an effectual variable. 
$\mathbf{H 8}_{\mathbf{0}}$ - Poor knowledge of financial management is independent of education of women entrepreneurs as an effectual variable.

H9 $\mathbf{9}_{\mathbf{0}}$ - Lack of technological skills as a problem for women entrepreneur is independent of lack of need of achievement in women entrepreneurs as an effectual variable.

H10 $_{0}$ - Prospect in service and manufacturing business is independent of current type of industry in which women entrepreneur own their business venture.

Sub Hypotheses for $\mathrm{H} 10_{0}$ are the following:-

$\mathbf{H 1 0 A}_{\mathbf{0}}$ - Prospect in service industry businesses is independent of current type of industry in which women entrepreneur own their business venture.

$\mathbf{H 1 0 B}_{\mathbf{0}}$ - Prospect in manufacturing industry is independent of current type of industry in which women entrepreneur own their business venture.

\subsection{Scope and limitation of study}

This is an exploratory study based on an empirical survey conducted by the researcher in the State of Gujarat. The work does not intend to study any specific industry rather aims to identify the distribution of women entrepreneurs in the various industries of MSME sector. The purpose of study nowhere intends to identify urban/rural phenomenon of entrepreneurship rather trying to identify state-wide phenomenon. Owing to the objectives of the study the businesses which were established 2015 or before are included to study. Women Entrepreneurs of both registered as well as unregistered units are considered as respondents because of the fact that the units reflected in government data were either closed, or shut down or the unit is originally run by male entrepreneurs without women, who is apparently the documented owner of the unit, having nil knowledge about the business activity which does not match our definition of women entrepreneurs.

The research is based on the lands of Gujarat hence language barrier has been most important for the researcher. The interview schedule framed by the researcher has been 
translated in Gujarati to cope up with this limitation which became instrumental to interact and extract responses from the respondents.

Besides language other barriers have been approach of those women owners (respondents) who sought husband's permission to respond to the researcher as on repeated approaches respondent faced difficulty in reaching to these women to understand their point of view. It highlights that in businesses even when woman and man has equal role to operate the business, man always has an upper hand when it comes to decision making.

Government data also challenged researcher to track the units as reflected in the list of registered businesses. Many registered units were mostly shut or women owner respondents showed their inability to respond to the researcher even on repeated approaches made by the researcher owing to numerous psychological barrier or personal engagements. It was further found that these businesses were basically handled by man instead of woman, therefore did not fall under the sampling frame of this work.

The crucial limitation of the study has been the time constraint faced by participating respondent women entrepreneurs due to which in Pilot Testing phase they pleaded their inability to answer on those set of questions which asked for ranking set of responses in an order or likert scale based responses as it is time consuming. In addition to this, the analysis of likert scale based questions at pilot testing phase of the research, resulted to be biased and hence it hampered the reliability of tests. These reasons clubbed together curbed the researcher to finalize on likert scale based questions in the final interview schedule. Therefore, the final interview schedule is based on nominal data.

\subsection{Sampling}

The field of inquiry constituting a 'Population' in this study is 'Women Entrepreneurs' of the Gujarat, a state in western India. As per the Fourth All India Census of MSMEs, which was conducted during 2006-07 covering all MSMEs registered up to 31/03/2007 with State Industries Commissionerate under MSME Development Act - 2006 the total number of women run businesses in Gujarat is 23629 as show in Table.1.11 in chapter 1. 
Sample size that needs to be calculated considering 23629 as the population gives 378 as a sample size which shall be surveyed keeping confidence level at 95 per cent.

The study has been conducted in the timeline January, 2015 to May, 2016 hence it is expected that the number of women owned businesses have risen beyond the abovementioned figure of 23629 which lacks official records. Therefore considering the total of 23629 (women owned business units) as base, the researcher selects 70 women owned business units to be approached for the purpose of pilot test from the list of registered units which has been provided by Statistical Department of Industries Commissionarate, Gujarat, on basis of simple random sampling. The researcher finds the existence of more number of proxy women owned business units than real. Upon approaching the enlisted units for a number of times researcher came across following responses:- a) the unit is shut, b) the women owner as per the list of statistical department is unable to come for the interview because of her personal or medical conditions and the researcher has to talk to the male member of the business who is actively involved in the day to day activity of the business and c) the women owner does not run the business but the male member of the family runs the business. On account of this, researcher adopts alternative measure i.e. snowball sampling in pilot test phase to collect responses from desired respondents and can interview 45 women entrepreneur respondents to complete this preliminary phase successfully.

Owing to the inability of researcher to contact owners of registered women owned business units enlisted in the list provided by the Statistical Department of Industries Commissionarate, Gujarat, and for the successful completion of the study the researcher strategically targets women entrepreneurs based on simple random sampling from the following:-

i) The exhibitions (Exhibition at Ahmedabad Haat, Bhuj Haat and Mega Women Expo from 14 to 17 April, 2016) which have been organized for women entrepreneurs to market their products

ii) Adopts snowball approach to reach women entrepreneurs at ground level who are famous among their social circle to own and actively run business/es for a long period of time

iii) Approaches NGO (which work to aid women entrepreneurs at grass root level to assist them for issues like finances, marketing or any other case of need) and 
iv) Attends conferences/seminars (Vibrant Garima, 19-21 December, 2016, National Women Conclave, 21 May, 2016) which are organized by GCCI with active participation of the members of Business Women's Wing)

With above approach, researcher is able to select and interview 425 women entrepreneur respondents which is a higher number than 378 as calculated. Since for the survey both registered and unregistered firms are covered hence researcher chooses a sample size which is more than 378 .

The responses of 24 respondents could not be considered for the purpose of analysis due to their incompleteness in one or the other sense therefore being incompetent in sufficing the purpose of analysis. For this reason a total of 401 responses have been considered for the purpose of final analysis.

The bifurcation of city wise data among these cities is as shown in Table 3.1:-

TABLE 3.1

City wise data collection

\begin{tabular}{|c|c|c|c|}
\hline Label No. & Name of City & Region & $\begin{array}{c}\text { Number of } \\
\text { Respondents }\end{array}$ \\
\hline 1 & Ahmedabad & Central & 145 \\
\hline 2 & Surat & South & 65 \\
\hline 3 & Rajkot & Saurashtra Peninsular & 58 \\
\hline 4 & Vadodara & East & 56 \\
\hline 5 & Kachch & West & 29 \\
\hline 6 & Gandhinagar & North & $\mathbf{4 0 1}$ \\
\hline
\end{tabular}

Primary Source

\subsection{Sampling frame}

A sampling frame should essentially be the representative of 'Population' under scanner. The researcher after following the procedure as mentioned in Section 3.4 finally 
considers women entrepreneurs with following features to be surveyed for the purpose of study:-

- Who owns and manages the functions of the business enterprise in non-agricultural industrial activity registered or unregistered.

- The business may be new (started not later 2015) or already established.

- The women must invest most of the day's time or otherwise towards business activities.

- The women invests her own (or borrowed) capital resources, even if in lower proportion (in case of micro enterprises of informal sector).

- She identifies opportunity and bear risk to organize and mobilize the factors of production and the resources of the enterprise

- Individually as a self-employed or in collaboration as a partner of business or as a member of a family business

\subsection{Data collection}

Data collection has been done for both pilot test and for the final study with the help of personal interviews by using structured schedule.

A total of 446 women entrepreneurs have been interviewed in two phases:-

a. 45 respondents for Pilot Testing and

b. 401 respondents for full study after pilot testing

45 women entrepreneurs basically from Ahmedabad and Gandhinagar cities are interviewed for the pilot test during January, 2015 to May, 2015. Experiences from pilot study guided researcher to make following changes in schedule:-

- Addition of questions for better insight of the study.

- Development of 'Gujarati' (local language) version of schedule to facilitate respondents to respond with better understanding due to their language barrier towards English language.

- Inclusion of yes/no (nominal data) type of responses instead of rank based or likert scale responses because of two reasons- a) women entrepreneurs are usually busy 
with their schedule and hence finds it time consuming to respond to likert scale or rank based responses, b) due to the objectives, this study includes women entrepreneurs ranging from women who run business at a micro scale to women who run their business at medium scale; irrespective of the scale of the businesses, women entrepreneurs are unable to give ranking to variables or respond to the likert scale based responses.

With the help of reworked schedule researcher has collected data from six cities [1. Central (Ahmedabad), 2. South (Surat), 3. Saurashtra peninsular (Rajkot), East (Vadodara), 5.West (Kachchh) and 6. North (Gandhinagar)] of Gujarat as mentioned in the following Fig.3.1.

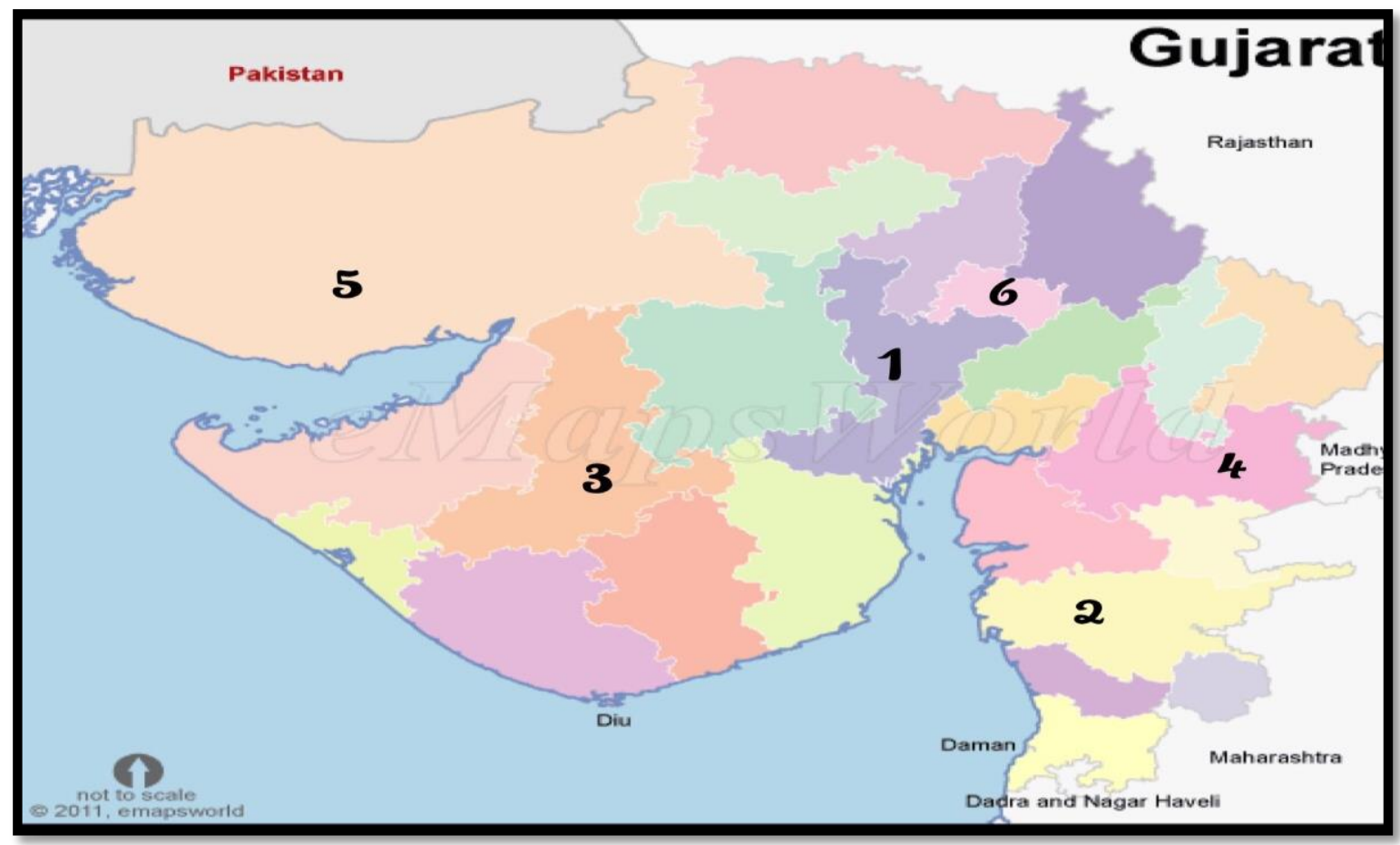

Source-Map downloaded from e-Maps World and labeled by researcher

FIG 3.1

Selected cities for data collection

On the basis of geographical features western Gujarat is classified into Saurashtra Peninsular and Kachch region (National Wetland Atlas, 2010), on this basis researcher has chosen two cities to represent Western Gujarat. Primary data has been collected with 
the help of structured schedule administered by the researcher and responded by women entrepreneurs as respondents. Secondary data has been collected from number of institutions (as mentioned in Table.3.2) and internet based government reports.

TABLE 3.2

Organizations and Primary/Secondary Data Received

\begin{tabular}{|c|c|}
\hline Organization Visited & Type of Primary/Secondary Data Received \\
\hline Industries Commissionarate & List of Registered MSME Units \\
\hline $\begin{array}{l}\text { Gujarat Women Economic Development } \\
\text { Corporation , Gandhinagar }\end{array}$ & Data pertaining to State $\mathrm{S}$ \\
\hline $\begin{array}{l}\text { Gujarat Livelihood Promotion Company Ltd, } \\
\text { Gandhinagar }\end{array}$ & $\begin{array}{l}\text { Data regarding unregistered women } \\
\text { entrepreneurs and data pertaining to State } \\
\text { Specific Schemes }\end{array}$ \\
\hline $\begin{array}{lll}\text { Gujarat } & \text { Chamber of Commerce } & \text { and } \\
\text { Industries (Ahmedabad and Surat) } & \end{array}$ & $\begin{array}{l}\text { Data regarding unregistered women } \\
\text { entrepreneurs and data pertaining to State } \\
\text { Specific Schemes }\end{array}$ \\
\hline Centre for Entrepreneurship Develop & $\begin{array}{l}\text { Data pertaining to State Specific Schemes } \\
\text { and data related }\end{array}$ \\
\hline IIM-A Library & Material pertaining to Review of Literature \\
\hline $\begin{array}{l}\text { Entrepreneurship Development Institute of } \\
\text { India }\end{array}$ & $\begin{array}{l}\text { Data pertaining to State Specific and Centre } \\
\text { Specific Schemes }\end{array}$ \\
\hline $\begin{array}{l}\text { International Centre for Entrepreneurship and } \\
\text { Career Development (ICECD) }\end{array}$ & $\begin{array}{l}\text { Reports generated by ICECD in collaboration } \\
\text { with institutions like IDBI, UNESCAP etc. }\end{array}$ \\
\hline Central University of Gujarat Library & Material pertaining to Review of Literature \\
\hline MSME Department , Ahmedabad & Data pertaining to State Specific Schemes \\
\hline NGOs in Kachch, Rajkot and Surat & $\begin{array}{l}\text { Data regarding } \begin{array}{c}\text { unregistered } \\
\text { entrepreneurs and data pertaining } \\
\text { Specific }\end{array} \text { Schemes } \\
\text { State }\end{array}$ \\
\hline
\end{tabular}

Primary Source

\subsection{Statistical tools of analysis}

The primary data collected with the help of structured schedule, are analyzed using SPSS and MS Excel. Various tools like frequency distribution, cross tabulation, percentages, graphs, chi-square, etc. are used for the purpose of analysis. Tabulation and graphical 
presentations are used for better understanding of the results. Since most of the data are category variables, chi-square is used for testing hypothesis.

Additional Methodologies - Although due to the limitation as mentioned in Section 3.3, the researcher has limited to the collection of nominal data which led to performance of non-parametric test i.e. chi-square test of independence, the researcher strongly believes that in future for the similar kind of studies, researchers may collect ordinal data or interval data (for example while asking questions related to operational output like income, profit etc) so that parametric tests can be performed and much reliable results can be achieved. With the availability of ordinal data it becomes possible to test the normality of the data which is a prerequisite for many statistical tests because for these tests it is an assumption that the data is normal. The variousparametric tests that can be performed are Mann-Whitney U-test, Kruskal-Walis test, independent sample t-test and ANOVA.

\subsection{Scheme of chapterization}

Chapter 1 - Introduction - This chapter encompasses introduction to entrepreneurship, women entrepreneurship, MSME sector in India, theories of entrepreneurship, types of entrepreneurs, evolution of entrepreneurship in India, women entrepreneurship in India, entrepreneurship in Gujarat, national and state specific schemes for women entrepreneurs, statement of problem, research questions and limitation of the study.

Chapter 2 - Review of Literature - Besides mentioning the research gap, review of literature has been divided into three major heads including theoretical background pertaining to international evidences, national evidences and Gujarat Specific evidences.

Chapter 3 - Research Methodology - This chapter details about objectives, hypothesis, scope of study, sampling method, data collection, statistical tools of analysis and tentative scheme of chapterization. 
Chapter 4 - Data Analysis and Interpretation - This chapter has been divided into sections as mentioned - 4.1. Demographic profile of women entrepreneurs, 4.2.Starting a Business - Methods and Reasons, 4.3. Profile of Women Owned Businesses, 4.4. Source of Continuous Support and Enabling Factors for Women Entrepreneurs, 4.5. Problems faced by Women Entrepreneurs and 4.6. Prospects for Women Entrepreneurs to analyze the data collected and interpreted to come to well studied conclusion.

Chapter 5 - Findings, Conclusion \& Suggestion - This forms important chapter of the study as portraying a clear picture of the findings pertaining to the problems and prospects of women entrepreneurship with special reference to MSMEs in the state of Gujarat thereby suggesting some measures to address the problems with immediate effect. After concluding the study at the end future scope of research has been pointed out to draw attention to untouched corners of this field of study.

\section{References}

Bahmani, S., Sotos, F.E. \& Gracia, I.P. (2012).'Women, Research and Entrepreneurship'. Galindo, M. \& Ribeiro (Eds). Women's Entrepreneurship and Economics. London, UK: Springer.

ISRO and BISAG (2010).National Wetland Atlas - Guajarat. Retrieved from http:/gujenvis.nic.in/PDF/National\%20Wetland\%20Atlas\%20-\%20Gujarat.pdf

Laerd Statistics. Retrieved from https://statistics.laerd.com/spss-tutorials/testing-fornormality-using-spss-statistics.php 


\section{CHAPTER - IV}

\section{Data Analysis and Interpretation}

Data collection in this study has been most crucial part for it being most insightful to the researcher in being able to give words to the observation done on field. This chapter thrives to analyze data collected from the field as explained in Chapter-3, Section 3.5.

The analysis of data basically caters to test the hypothesis and answer research questions. The researcher makes use of IBM SPSS Statistics 21.0 version to analyze data and Microsoft Windows 2007 Office Excel Worksheet to present results in form of tables, bar charts and pie charts wherever applicable. For analysis, the significance level is 0.05. Using the sample data chi-square test of independence is conducted. With the help of chi-square test of independence on the sample data, degrees of freedom, expected frequency counts and the chisquare test statistics has been computed. While writing interpretation researcher has considered mentioning observations made, while interacting with survey respondents during field survey, as part of discussion.

This chapter is basically divided into following sections -

4.1. Demographic Profile of Women Entrepreneurs

4.2. Starting a Business - Methods and Reasons

4.3. Profile of Women Owned Businesses

4.4. Source of Continuous Support and Enabling Factors for Women Entrepreneurs

4.5. Problems faced by Women Entrepreneurs

4.6. Prospects for Women Entrepreneurs 


\subsection{Demographic Profile of Women Entrepreneurs -}

In this section the demographic profile of women entrepreneurs is analyzed and interpreted to comprehend upon the socio-economic background of women entrepreneurs in the State. This will enable the reader to relate the whole process of women entrepreneurship with that of their social and economic status in the society. Age, educational background, marital status, husband's education, husband's occupation, father's education, father's occupation, mother's education, mother's occupation, presence of close of distant family members with prior business experience and assistance received from those relatives with prior business experience are the contents of data collection while illuminating upon the demographic profile of women entrepreneurs in Gujarat.

\section{A. Age}

Table 4.1 and Chart 4.1 indicates that there is a dominance of women entrepreneurs aged between 36-45 years (34.9 per cent) and 25-35 years (33.9 per cent) followed by women entrepreneurs aged between 46 to 55 years (17.7 per cent) followed with huge difference by women entrepreneurs aged above 55 years (7.2 per cent) and below 25 years (6.2 per cent).

This result is similar to the findings of various previous researches made by researchers owing to the fact that women look for established source of income in their late $20 \mathrm{~s}$. Before that women are not keen to enter into any occupation on account of primary motive of completing their education. Women who are now into their late 40s (and beyond) have not shown impressive participation in entrepreneurial activities. The reason behind this is the fact that when they were in their 20 s or 30 s, an age when person is inclined to take up a career, there were less enabling factors in comparison to today's scenario. 
TABLE 4.1

Age distribution of Women Entrepreneurs

\begin{tabular}{|c|c|}
\hline Age of WE/s & Frequency \\
\hline Below 25 & 25 \\
\hline $25-35$ & 136 \\
\hline $36-45$ & 140 \\
\hline $46-55$ & 71 \\
\hline Above 55 & 29 \\
\hline Total & 401 \\
\hline
\end{tabular}

Primary Data

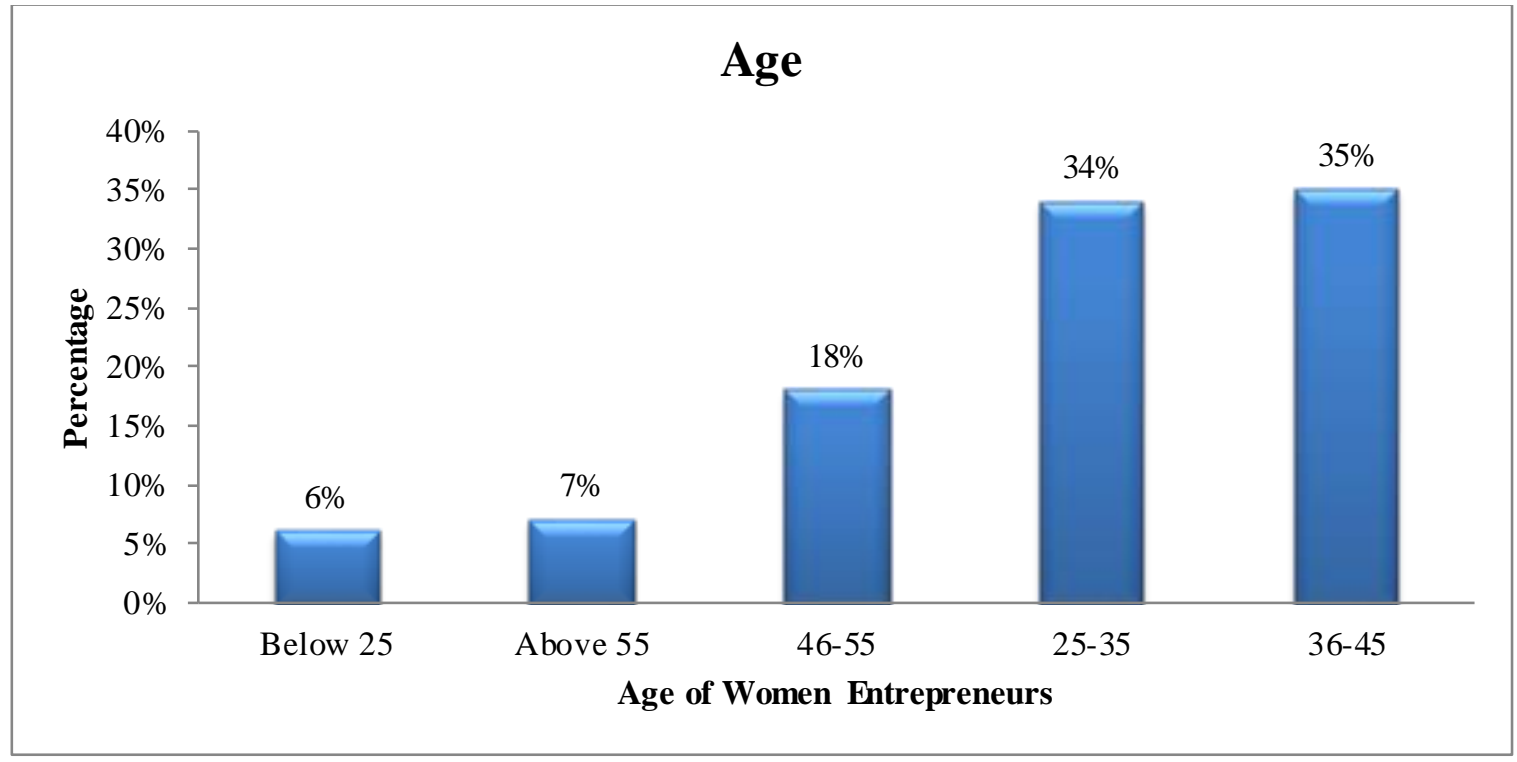

Source-Primary data

CHART 4.1

Bar chart to represent the age distribution of women entrepreneurs

\section{B. Education}

The analysis of education level, as shown in Table 4.2 and Chart 4.2, defines that woman entrepreneurs in MSME sector of Gujarat are fairly educated with maximum women (43 per cent) holding graduation degree followed by 25 per cent women continuing their study up to 
post graduation. Others reflect holding intermediate (HSC) (10 per cent), below matriculation (10 per cent), matriculation (SSC) (8 per cent) or illiterate (3 per cent). This is due to the fact that researcher is not confining the study only in rural areas rather has a focus to conduct an open research to analyze the women entrepreneurs from urban as well as rural areas.

TABLE 4.2

Education level of Women Entrepreneurs

\begin{tabular}{|c|c|}
\hline Education Level & Frequency \\
\hline Illiterate & 12 \\
\hline Below Matriculation & 40 \\
\hline Matriculation & 34 \\
\hline Intermediate & 40 \\
\hline Graduate & 174 \\
\hline Postgraduate & 101 \\
\hline Total & 401 \\
\hline
\end{tabular}

Source-Primary data

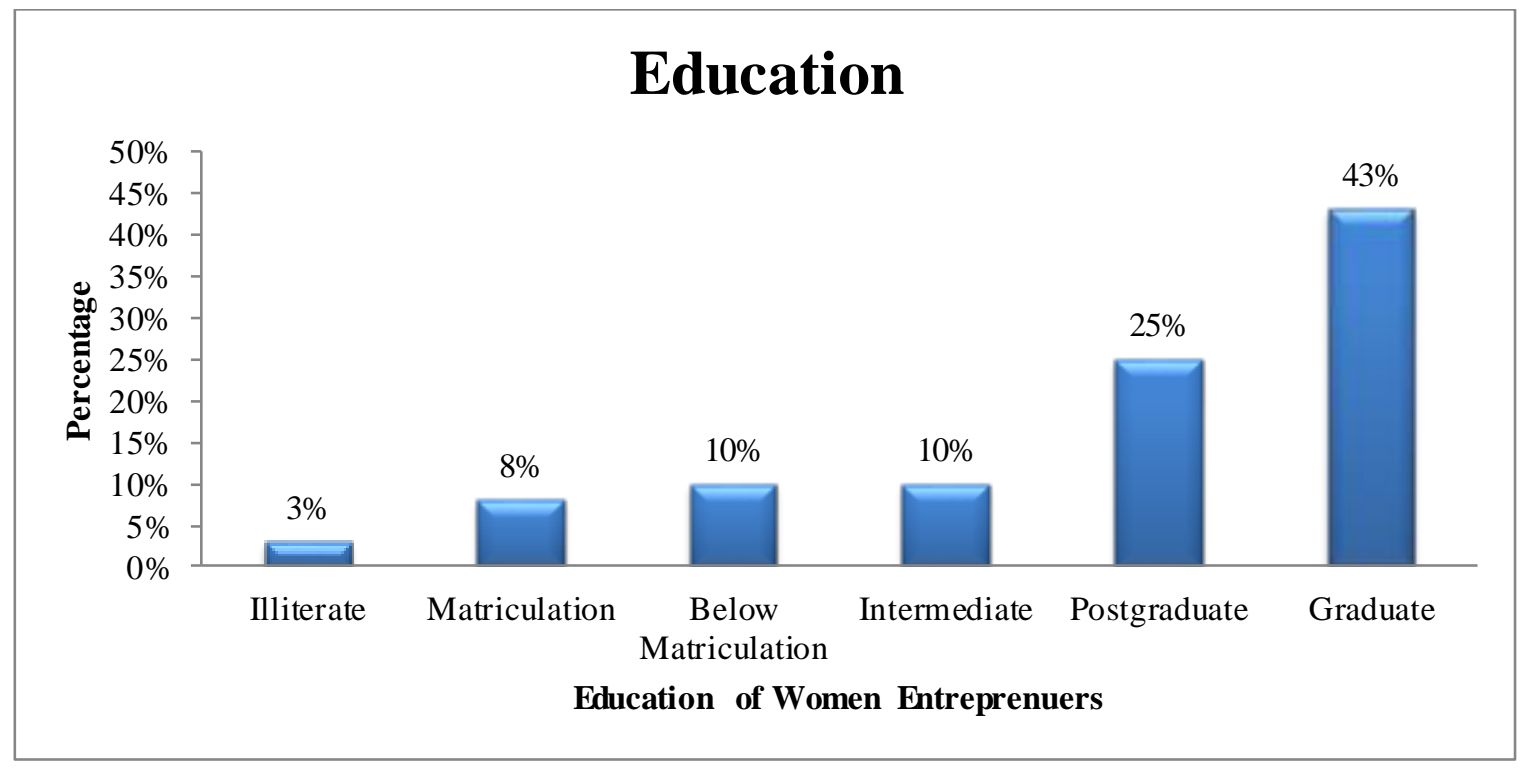

Source-Primary data

CHART 4.2

Bar Chart to Represent the Education Level of Women Entrepreneurs

\section{Marital Status}

Most of the respondents (81 per cent) are married followed by single (13 per cent), divorced (3 per cent) and widow (3 per cent) as shown in Table 4.3 and Chart 4.3. 
The reason behind this is that women get a lot of support from her husband for establishment of business and hence as per this survey it is concluded that in Gujarat husbands support becomes most important motivating factor for women entrepreneurs to settle down in this occupation.

TABLE 4.3

Marital Status of Women Entrepreneurs

\begin{tabular}{|c|c|}
\hline Marital Status & Frequency \\
\hline Single & 53 \\
\hline Married & 323 \\
\hline Divorced & 11 \\
\hline Widow & 14 \\
\hline Total & 401 \\
\hline
\end{tabular}

Source-Primary data

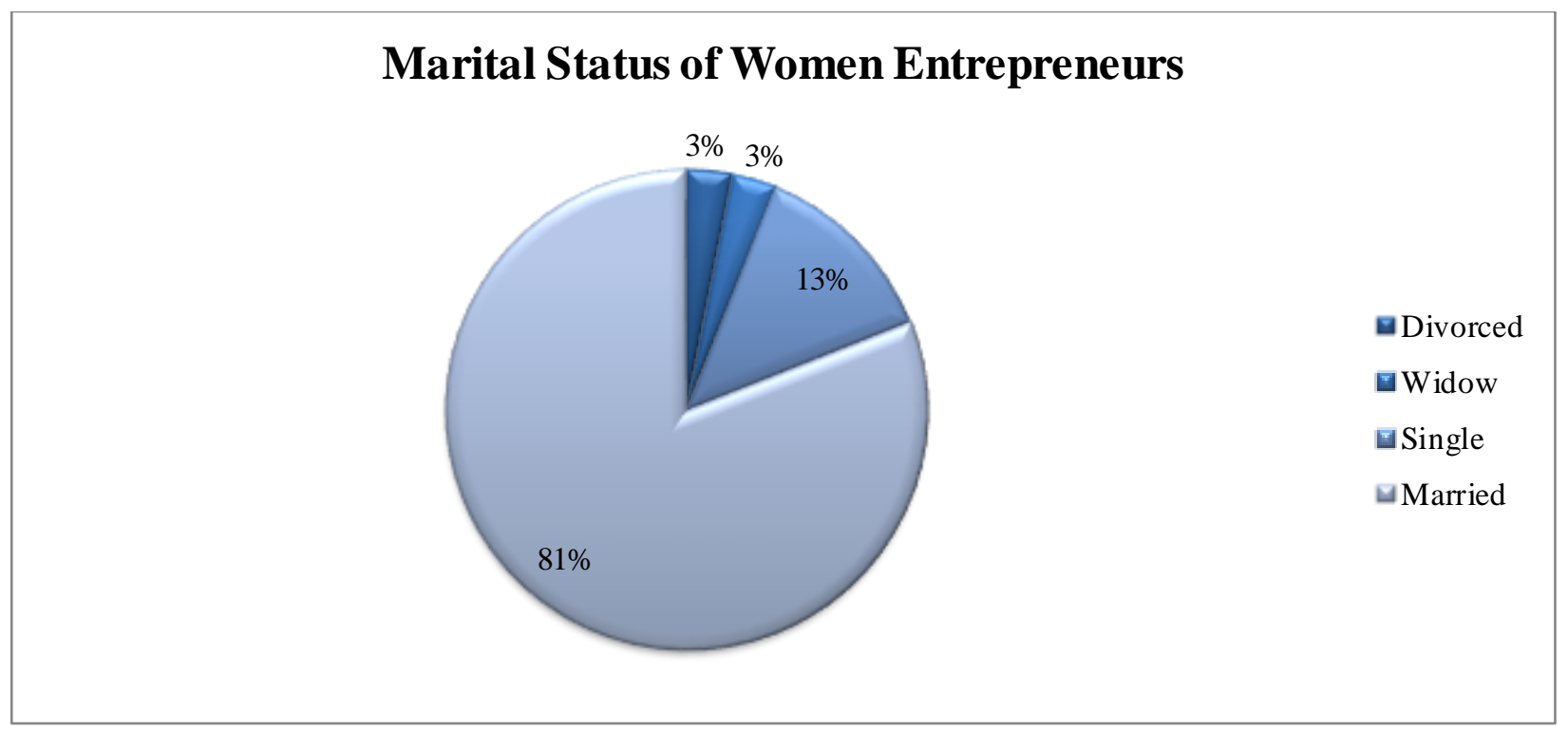

Source-Primary data

CHART 4.3

Pie Chart to Represent the Marital Status of Women Entrepreneurs

\section{Husband's Education}

Like educational background of respondents, educational level of husbands also seems to be majorly graduated (41 per cent) followed by post graduation (17 per cent), below matriculation (10 per cent), intermediate or HSC (9 per cent), matriculation or SSC (6 per 
cent) and illiterate (3 per cent) as represented in Table 4.4 and Chart 4.4. Here N.A represents those women entrepreneurs who are either unmarried or divorced.

In this question most women entrepreneurs who are divorced observed to be affronted on the mention of husband specific details hence researcher did not compel them to answer for this question rather chose to skip on being denied once.

TABLE 4.4

Husband's Education

\begin{tabular}{|c|c|}
\hline Husband's Education & Frequency \\
\hline Illiterate & 4 \\
\hline Below Matriculation & 41 \\
\hline Matriculation & 24 \\
\hline Intermediate & 36 \\
\hline Graduate & 165 \\
\hline Post Graduate & 67 \\
\hline N.A & 64 \\
\hline Total & 401 \\
\hline
\end{tabular}

Source-Primary Source

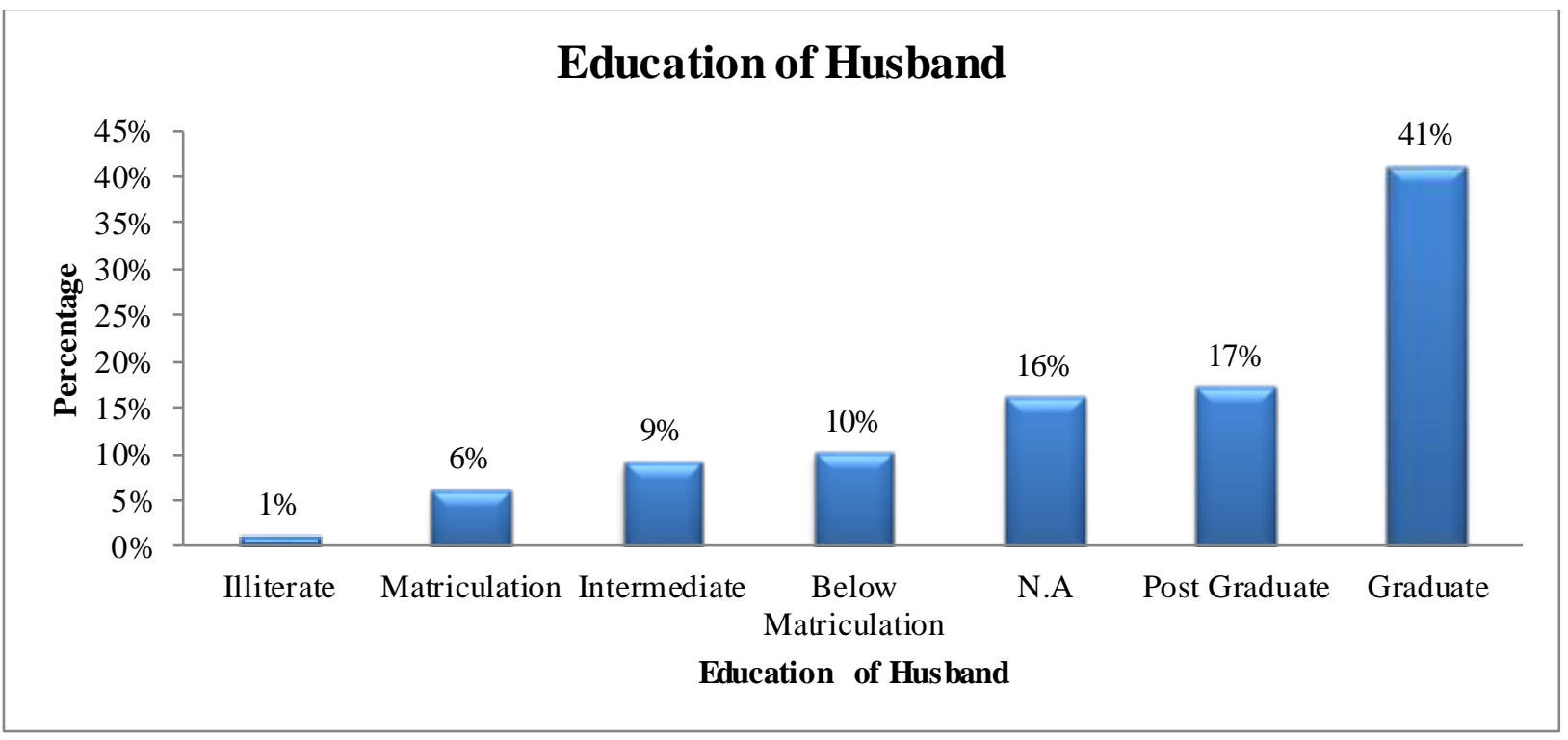

Source-Primary Source

CHART 4.4

Bar Chart to Represent Hus band's Education 


\section{E. Husband's Occupation}

It is interesting to note that in Gujarat majority of women entrepreneur's husbands (49 per cent) are in business as their primary occupation followed by government or private service (25 per cent), professional with own firm (5 per cent), others (3 per cent) and freelance professionals (1 per cent) as reflected in the Table 4.5 and Chart 4.5. Many studies also suggest that women entrepreneurs have a business background in form of husband or father or mother or any of the family members. It is also observed that many women entrepreneurs were first out of the husband wife duo to venture into business as an occupation. After wife has succeeded in her venture, husband has either joined the same business or started a business of his own. A focused study to venture this field of study can be an interesting endeavor. As far as husband's occupation is concerned, current set of data is positive on a relationship between family background and choice of entrepreneurship as occupation for respective respondents. Further facts will reveal whether is there an actual relationship existing between these two factors? Let us find out.

TABLE 4.5

Husband's Occupation

\begin{tabular}{|c|c|}
\hline Husband's Occupation & Frequency \\
\hline Business & 196 \\
\hline Private or Government Service & 100 \\
\hline Freelance Professional & 6 \\
\hline Professional with own firm & 22 \\
\hline Others & 13 \\
\hline N.A & 64 \\
\hline Total & 401 \\
\hline
\end{tabular}

Source -Primary Source 


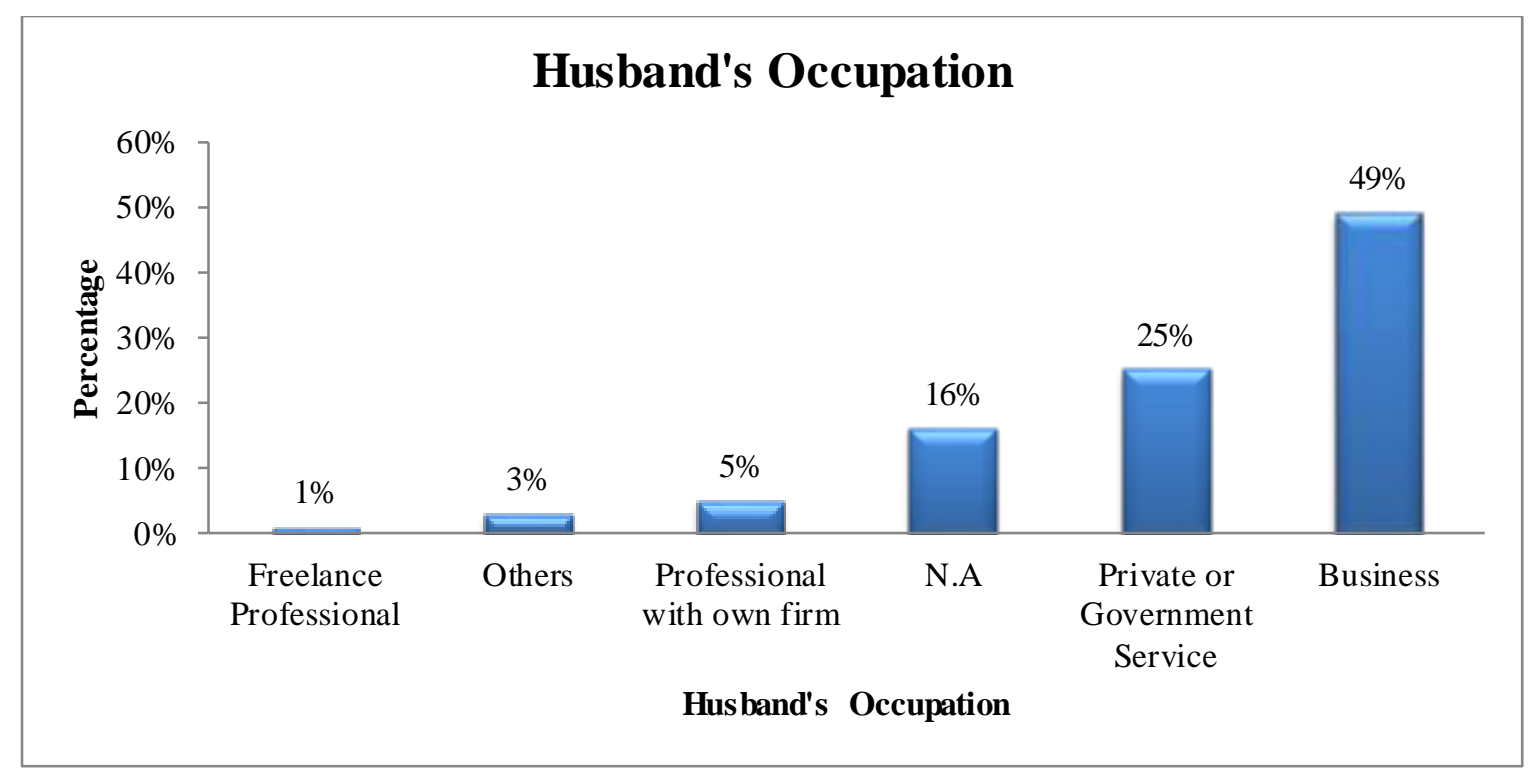

Primary Source

CHART 4.5

Bar Chart to Represent Husband's Occupation

\section{F. Father's Education}

In case of fathers educational level although it is observed that most of the respondent's fathers are fairly educated with an educational degree of graduation (32 per cent), but much lesser than respondent self and husband's educational level. This is directly followed by below matriculation (21 per cent), matriculation (14 per cent), post graduate (13 per cent), illiterate (11 per cent) and lastly intermediate (8 per cent) as shown in Table 4.6 and Chart 4.6 .

It is clear that although the data shows majority of fathers $(32 \%+13 \%)$ are holding degree or post graduate degree but a high number of fathers show education not at par with respondent self or education level of husbands of the respondents.

It is hence interpreted that Gujarat as a society has observed a growth as far as education is concerned and people, irrespective of their level of education (post graduate, graduate, intermediate, matriculate, below matriculation or else), have educated their wards to a higher level. 
TABLE 4.6

Father's Education

\begin{tabular}{|c|c|}
\hline Father's Education & Frequency \\
\hline Illiterate & 43 \\
\hline Below Matriculation & 86 \\
\hline Matriculation & 58 \\
\hline Intermediate & 33 \\
\hline Graduate & 129 \\
\hline Postgraduate & 52 \\
\hline Total & 401 \\
\hline
\end{tabular}

Primary Source

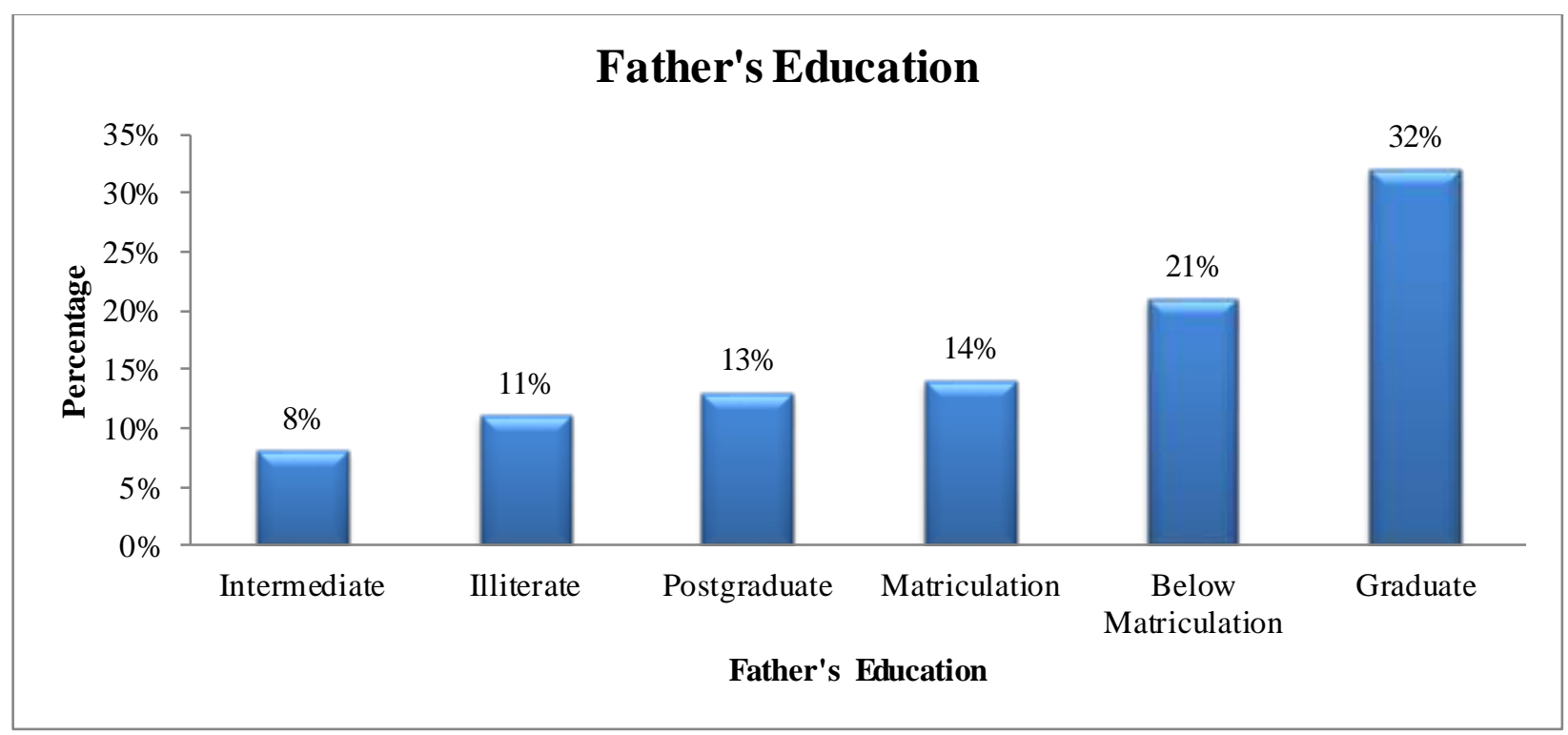

Source-Primary Source

CHART 4.6

Bar Chart to Represent Father's Education

\section{G. Father's Occupation}

Supplementing the revelation of husband's occupation the data shown in the Table 4.7 and Chart 4.7 also favors that family background does play in important part when it comes to choosing an occupation as in the current sample it is observed that majority of the respondents quote that their father own and run business (52 per cent) followed by private or government service (30 per cent), others (12 per cent), professional with own firm (3\%) and lastly freelance professionals (2 per cent). 
TABLE 4.7

Father's Occupation

\begin{tabular}{|c|c|}
\hline Father's Occupation & Frequency \\
\hline Business & 209 \\
\hline Private or Government Service & 120 \\
\hline Freelance Professional & 9 \\
\hline Professional with own firm & 14 \\
\hline Others & 49 \\
\hline Total & 401 \\
\hline
\end{tabular}

Source-Primary Source

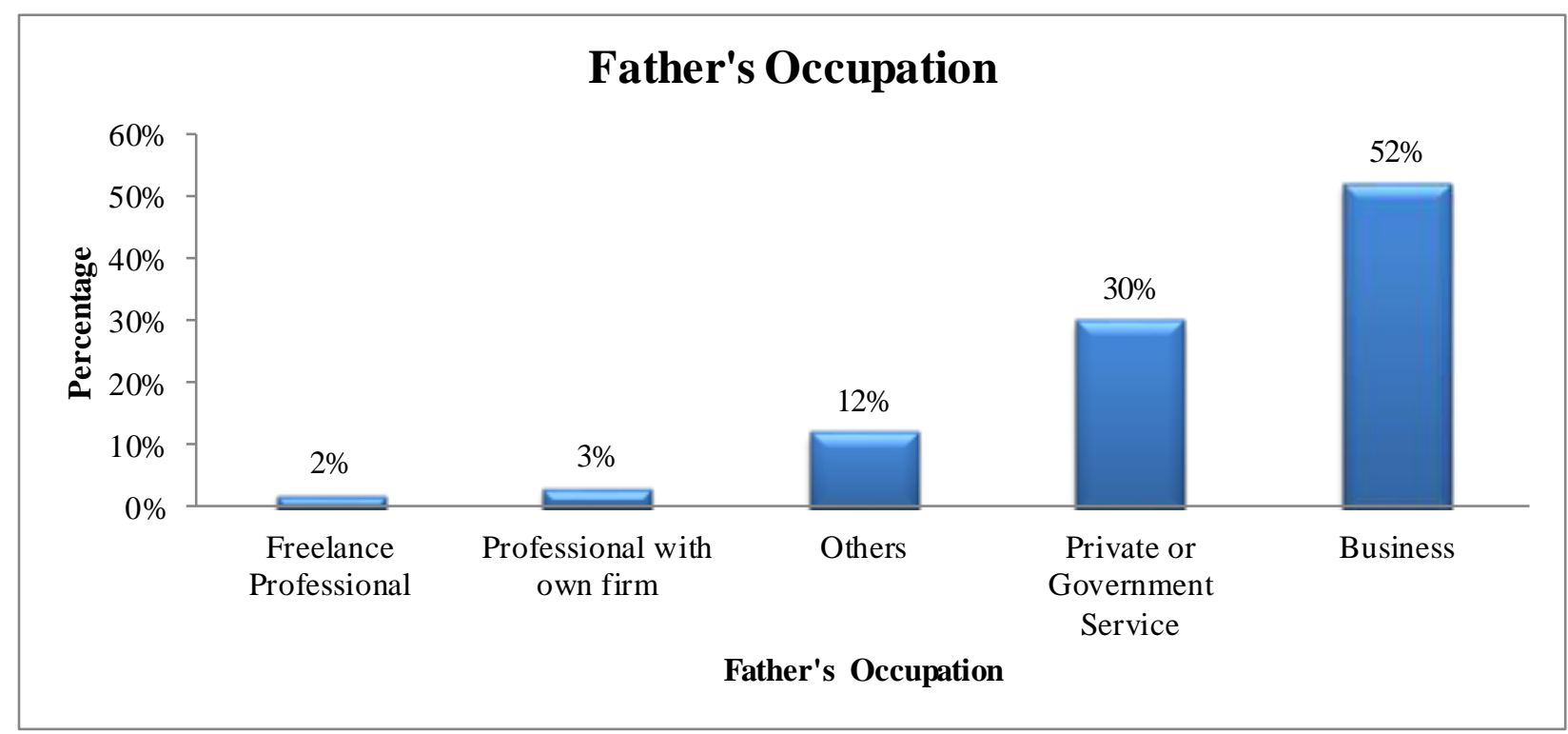

Source-Primary Source

CHART 4.7

Bar Chart to Represent Father's Occupation

\section{H. Mother's Education}

The data related to mother's education as shown in Table 4.8 and Chart 4.8 reveals the long ignored scenario of women education as it is the least out of the education of respondent self, husband's education level or education level of father. Although majority among respondents mother's are educated till below matriculation ( 27 per cent) followed by graduate ( 21 per cent, which is much less than others), matriculation (18 per cent), illiterate (16 per cent), intermediate (13 per cent) and lastly post graduate (5 per cent only). 
This data also helps us to understand that less education of mother and father has not deterred their wards to pursue higher education and today the scenario is much improved as can be observed in case of education level of respondent self and their husbands.

TABLE 4.8

Mother's Education

\begin{tabular}{|c|c|}
\hline Mother's Education & Frequency \\
\hline Illiterate & 63 \\
\hline Below Matriculation & 109 \\
\hline Matriculation & 71 \\
\hline Intermediate & 52 \\
\hline Graduate & 85 \\
\hline Post Graduate & 21 \\
\hline Total & 401 \\
\hline
\end{tabular}

Source-Primary Source

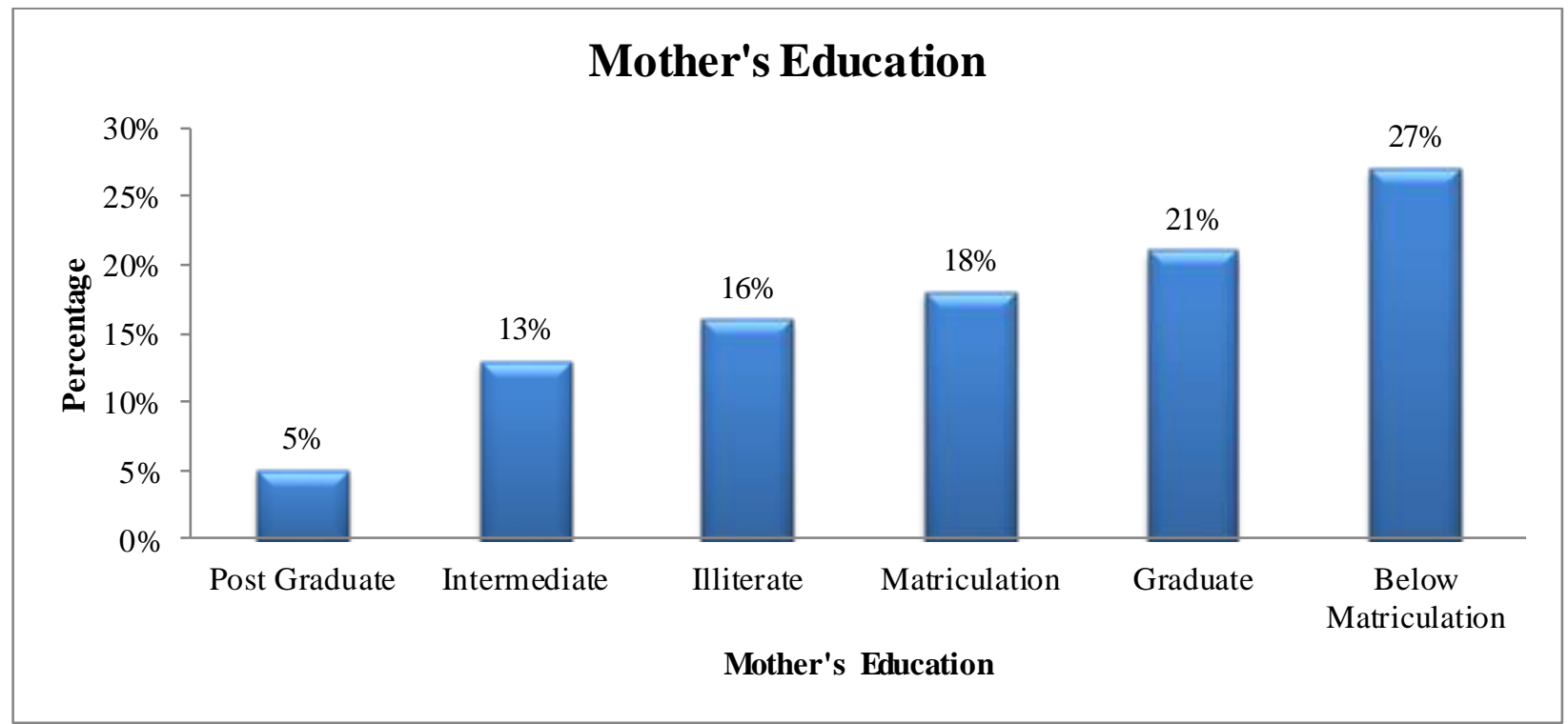

Source-Primary Source

CHART 4.8

Bar Chart to Represent Mother's Education

\section{Mother's Occupation}

The data pertaining to occupation of mother as represented in the Table 4.9 and Chart 4.9 reveals a different story of women entrepreneurs in the state of Gujarat. The current result shows that respondent's mothers have majorly remained at home (79 per cent) and performed 
obligations of raising their kids and taking care of home related responsibilities. Very few of the respondents have responded that their mother own and run a business (11 per cent) followed by mothers in private or government services (8 per cent) and lastly respondents who's mother are either freelance professional, professional with own firm or into other occupation for 1 per cent of the entire sample each.

If analyzed carefully, it indicates an attention-grabbing fact that there has been an immense growth in the number of women entrepreneur in the state of Gujarat with only 11 per cent of women owning and running a business approximately 20 years back in comparison to today's statistics.

TABLE 4.9

Mother's Occupation

\begin{tabular}{|c|c|}
\hline Mother's Occupation & Frequency \\
\hline Business & 43 \\
\hline Private or Government Service & 33 \\
\hline Freelance Professional & 3 \\
\hline Professional with own firm & 316 \\
\hline Home Maker & 3 \\
\hline Others & 401 \\
\hline Total & \\
\hline
\end{tabular}

Primary Source 


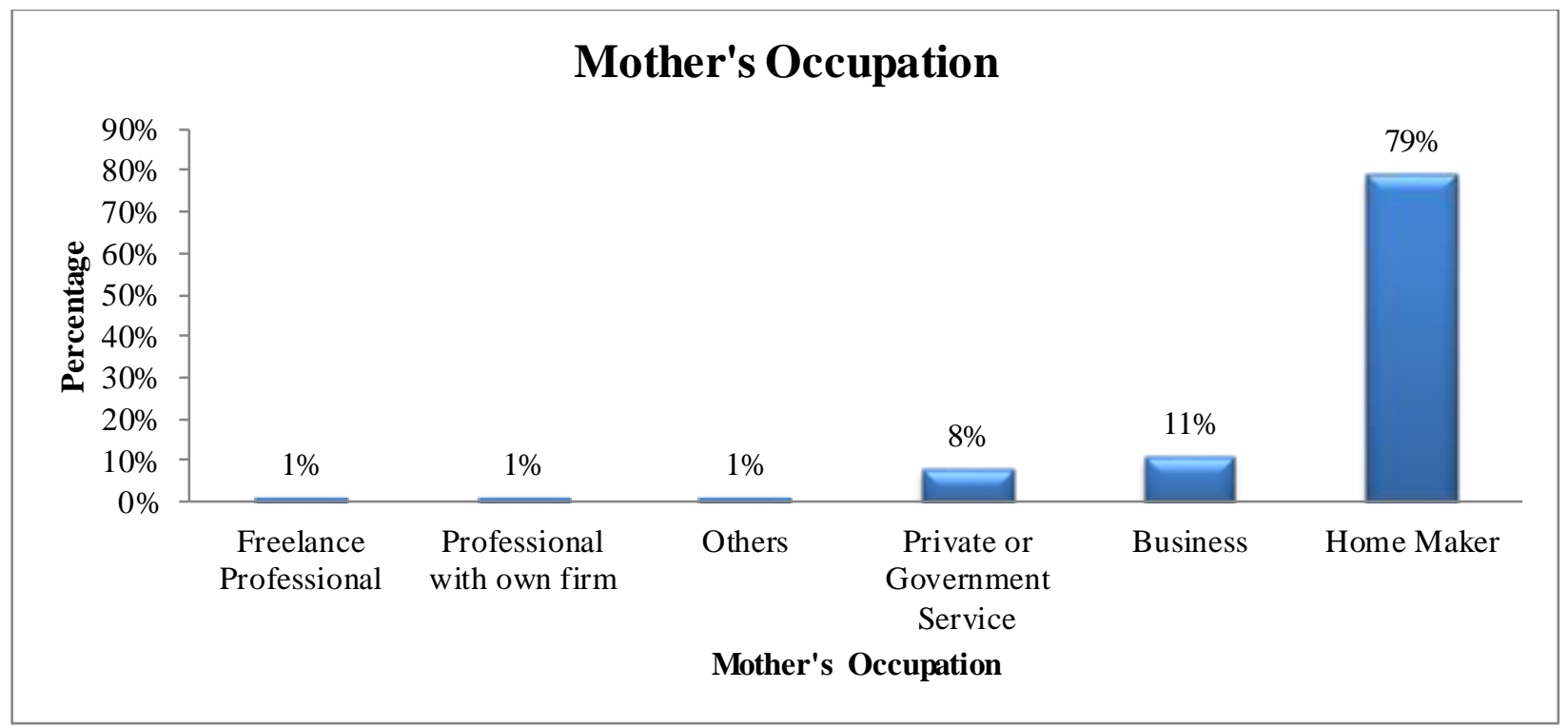

Primary Source

CHART 4.9

Bar Chart to Repres ent Mother's Occupation

\section{J. If anybody in the family has prior business experience}

This data will give us additional information on whether the occupation of women entrepreneurs has effect of family background or not.

It is visible in the Table 4.10 that 67 per cent of respondents agree that they have one or the other member of the family who has prior business experience and rest 33 per cent say they do not have any business related background. It should be noted that here family member means brother, sister, brother-in-law, sister-in-law, father-in-law, mother-in-law, uncles, aunts etc besides father and husband.

Let us see how helpful this is for the respondents to establish their business in the next set of data. 
TABLE 4.10

If anybody has prior business experience in family?

\begin{tabular}{|c|c|c|}
\hline $\begin{array}{c}\text { If any of the Family Member } \\
\text { has prior business Experience }\end{array}$ & Frequency & Percent \\
\hline Yes & 270 & $67 \%$ \\
\hline No & 131 & $33 \%$ \\
\hline Total & 401 & $100 \%$ \\
\hline
\end{tabular}

Primary Source

\section{K. If you received any help from them to start your business}

The prior data reveal statistics of 67 per cent of respondents agreeing to the question that they have some or the other family members who have prior business experience. Out of these 67 per cent respondents 42 per cent of respondents further agree to the question that they definitely received desired guidance and assistance from those family members who have prior business experience as represented in Table 4.11 and Chart 4.10. But 25 per cent of respondents disagree to this question.

The reason surfaced by the respondents majorly quotes that they could not receive desired guidance or assistance because the industry or business activity in which those family members are involved is altogether different from the industry or business activity in which they (respondent women entrepreneurs) want to practice entrepreneurship.

TABLE 4.11

Did Women Entrepreneur receive any help from those family members' who are already into business?

\begin{tabular}{|c|c|}
\hline $\begin{array}{c}\text { Did you get any help from those members of family who are } \\
\text { into business? }\end{array}$ & Frequency \\
\hline Yes & 171 \\
\hline No & 99 \\
\hline N.A & 131 \\
\hline Total & 401 \\
\hline
\end{tabular}

Primary Source 


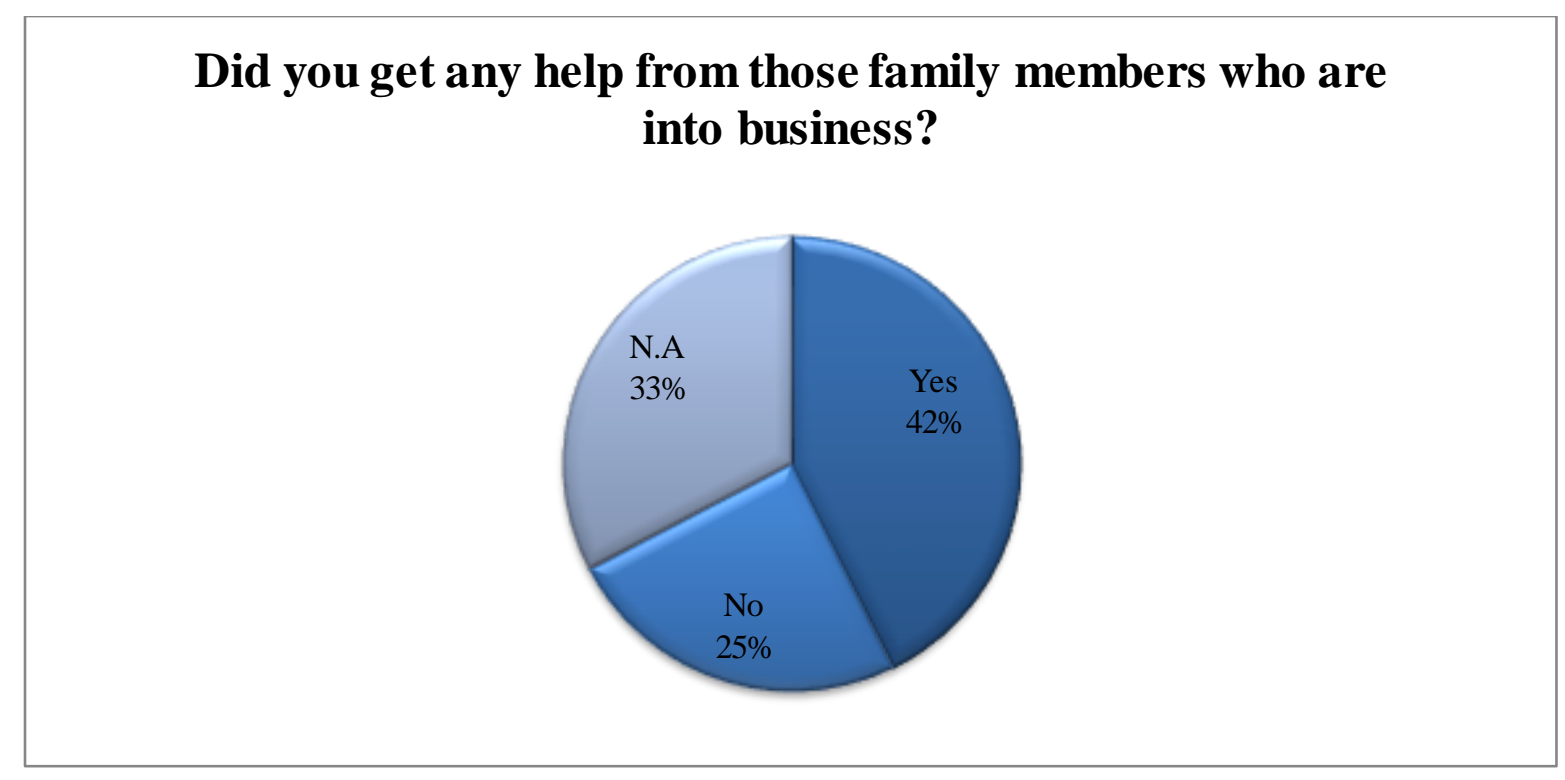

Primary Source

CHART 4.10

Pie Chart to represent did women entrepreneur receive any help from those family members' who are already into business?

\subsection{Starting a business - Methods and Reasons}

This section deals with the various methods women entrepreneurs adopted to start a venture; started venture by self, inherited it from family, bought it, inherited it from in-laws or by becoming member of SHG. It also seeks to confirm the reason that prompted women to pursue entrepreneurship as an occupation. This is studied to identify whether women's shift to entrepreneurship is necessity based or opportunity based.

\section{A. How did you start your business?}

When asked the mode to start their business 78 per cent of respondents acknowledge that they started their business by self followed 13 per cent agreeing that they have inherited business from their family i.e. from their mother or father, 4 per cent agrees that they have inherited business from their in-laws, 3 per cent confirming that they started business by 
becoming the member of one or the other Self Help Group and 1 per cent of the respondents declares that the business have been bought as shown in Table 4.12 and Chart 4.11.

This statistics indicates that the women entrepreneurs in Gujarat are proactive and self-starter. Most of them have started business by themselves and making every possible effort to grow it with every passing day. This illustrates the entrepreneurial spirit and culture women carry in Gujarat. This scenario is prevailing due to many reasons which are mentioned in Section. 4.6. A.

TABLE 4.12

Mode to start the business

\begin{tabular}{|l|c|}
\hline \multicolumn{1}{|c|}{ Mode to start the business } & Frequency \\
\hline Started business venture by my own & 314 \\
\hline Inherited it from my family & 53 \\
\hline I have bought & 4 \\
\hline Inherited it from my in-laws & 16 \\
\hline By becoming member of SHG & 14 \\
\hline Total & 401 \\
\hline
\end{tabular}

Primary Source

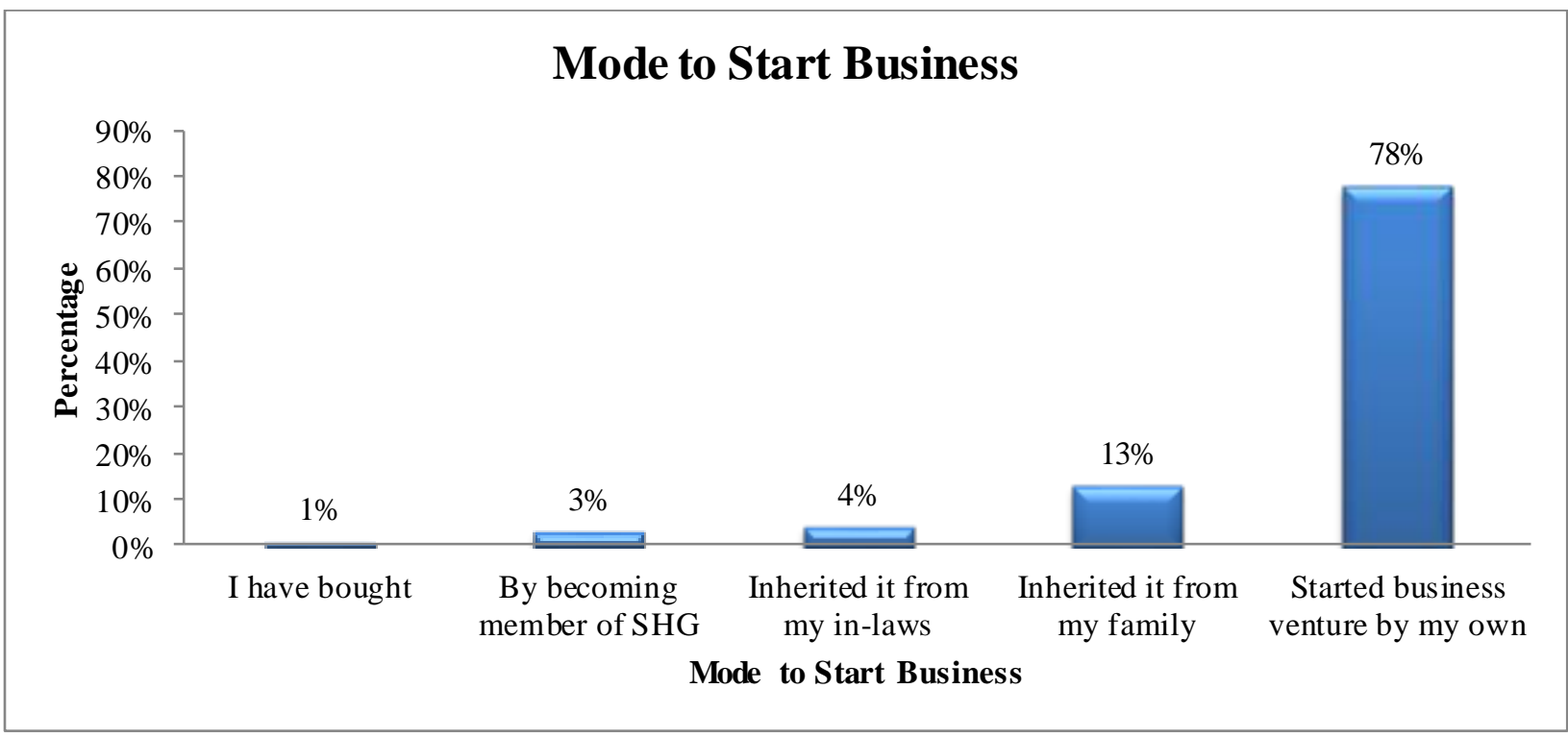

Primary Source

CHART 4.11

Bar Chart to represent mode to start business 


\section{B. What made you become an entrepreneur?}

When asked the reason to start the business most of the respondents admit that they always wanted to start their own business (52 per cent) followed by 32 per cent revealing it to be due to their weak financial condition (32 per cent) followed by because of either it being a family business or because their family has always been into business (18 per cent), 17 per cent have been observed quoting 'other' as the reason, 14 per cent followed entrepreneurial path to pursue their passion in the respective business activity, 8 per cent due to their strong business plan and mere 4 per cent due to lucrative government schemes as reflected in Table 4.13 and Chart 4.12.

TABLE 4.13

Reason to start business

\begin{tabular}{|l|c|}
\hline \multicolumn{1}{|c|}{ Reason to Start Business } & Frequency \\
\hline Family Business & 72 \\
\hline Weak Financial Condition & 130 \\
\hline Always wanted to start own business & 207 \\
\hline Due to lucrative Government Schemes & 17 \\
\hline Due to passion in this field / interesting field & 55 \\
\hline Due to strong business plan & 33 \\
\hline Others & 67 \\
\hline
\end{tabular}

Primary Source 


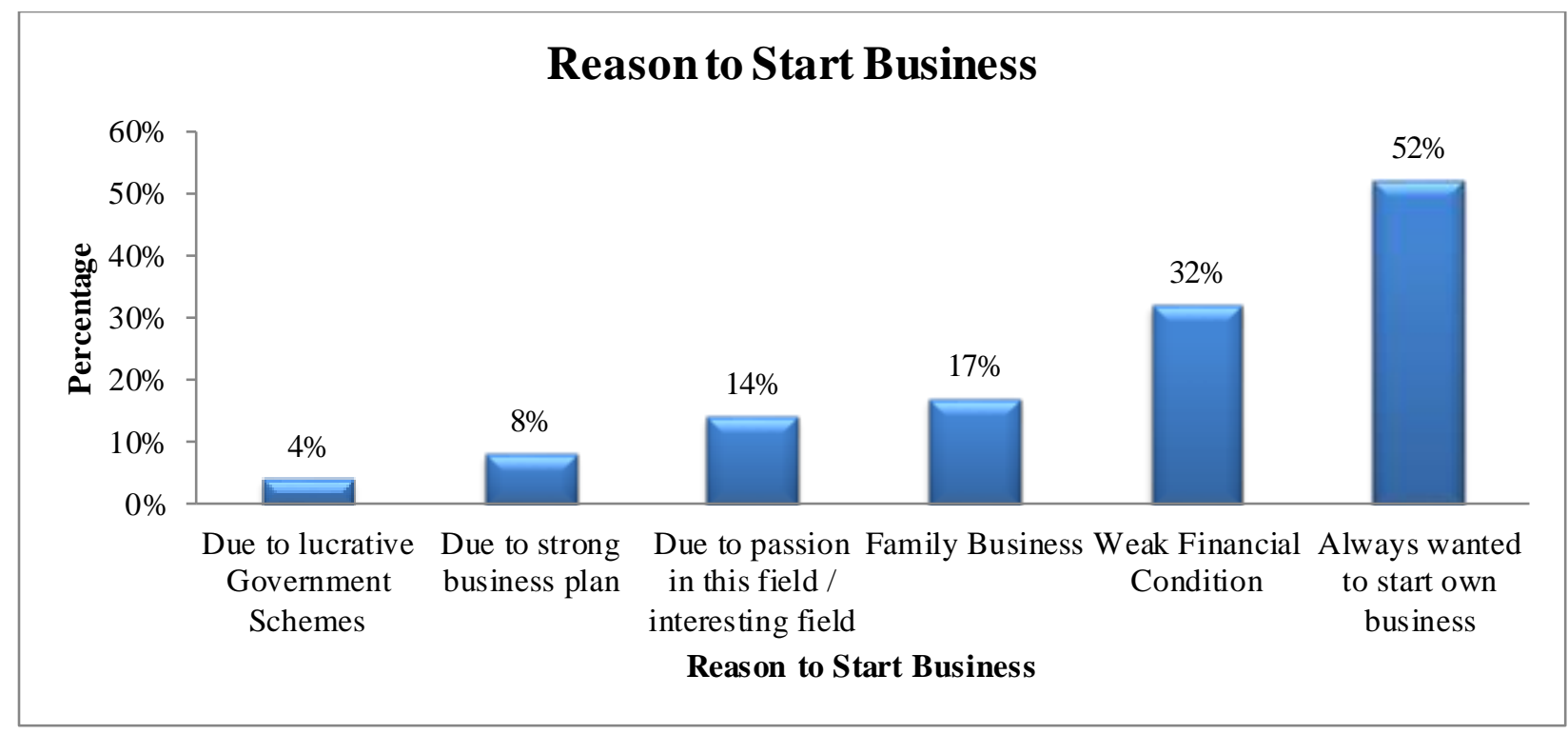

Primary Source

CHART 4.12

Bar Chart to represent the reason to start business

It should be marked that other reasons include reasons like due to sudden demise of husband, due to better future of their wards, to make use of their education for the betterment of society, to make use of their idle time and to pursue their own identity.

It is visible that more than 75-80 per cent of respondents are pursuing entrepreneurship due to pull factors like the everlasting zeal to start one's own business, the passion in respective business activity or industry, due to the interest generated because of belonging to a business family and the factor of firm confidence on the business plan.

Furthermore it is difficult to ignore those 32 per cent and more of respondents who believe that their reason to start a business venture is due to their weak financial conditions or due to sudden demise of spouse. 


\subsection{Profile of Women-owned business -}

Researcher has collected data to create a summarized picture of profile of businesses owned by women entrepreneurs in the state of Gujarat. The data is being analyzed to give answers to research questions like identifying the spread of women owned businesses in micro, small and medium sectors, identifying the registered versus unregistered businesses in case of women-owned businesses in the state, identifying the percentage of women entrepreneurs who have attended 'Entrepreneurship Development Program (EDP)' and its effect on their business growth are few important to mention.

\section{A. Year of Establishment}

This statistics will help us understand the length of existence of businesses owned by women entrepreneurs. With the study of Table 4.14 and Chart 4.13 it is clear that 48 per cent of respondents have started their business between years 2011 to 2015. Further 18 per cent of respondents have established their business in 2006-2010, followed by 13 per cent in 20012005, 9 per cent have established their business in 1996-2000, 5 per cent in 1991-1995, 3 per cent in 1985-1990 and 4 per cent of respondents have started their business before 1985.

TABLE 4.14

Year of establishment

\begin{tabular}{|c|c|}
\hline Year of Establishment & Frequency \\
\hline Before 1985 & 16 \\
\hline $1985-1990$ & 13 \\
\hline $1991-1995$ & 20 \\
\hline $2001-2005$ & 36 \\
\hline $2001-2005$ & 53 \\
\hline $2006-2010$ & 71 \\
\hline $2011-2015$ & 192 \\
\hline Total & 401 \\
\hline
\end{tabular}

Primary Source 


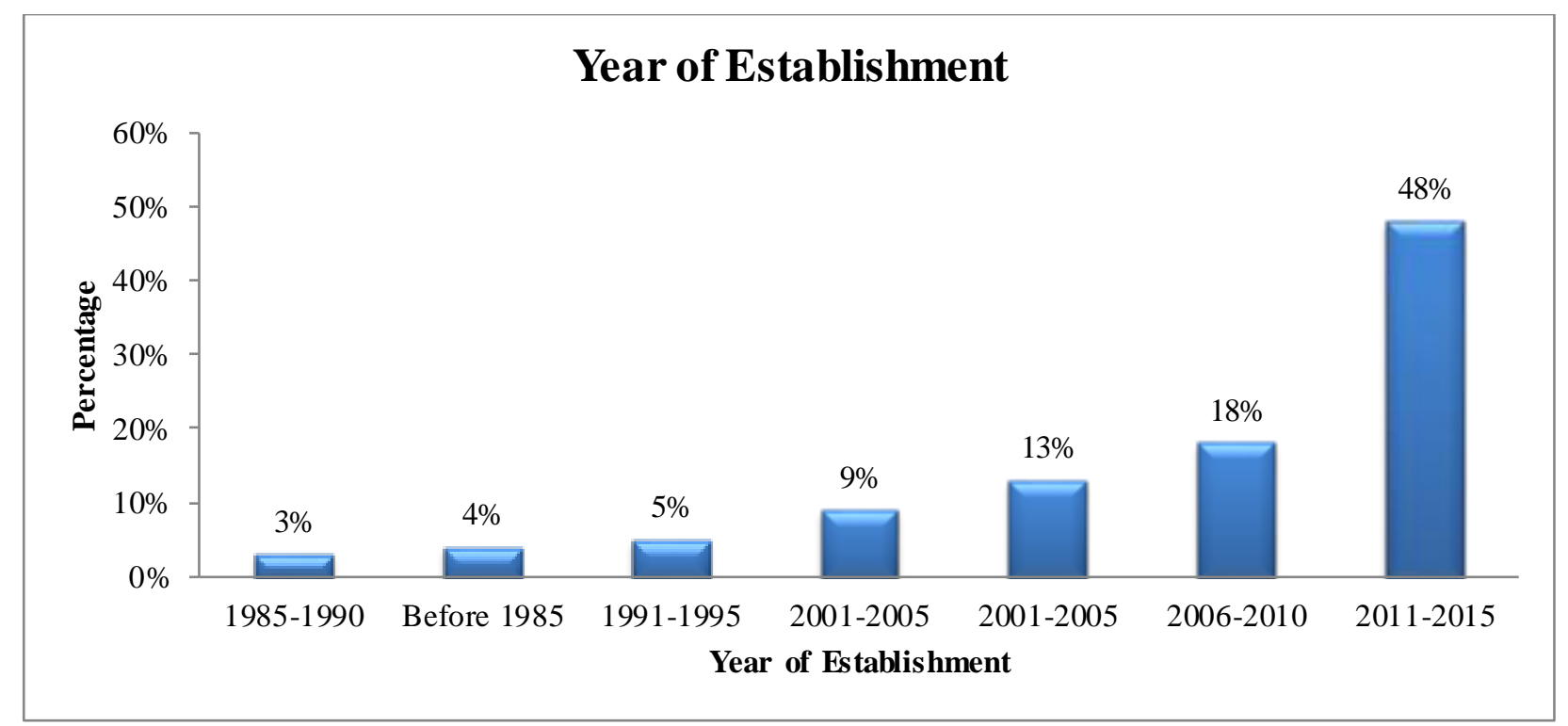

Primary Source

CHART 4.13

\section{Bar Chart to represent the year of establishment}

Three important facts are unleashed by this statistics. First is the growth trend showing the augmentation of number of business ventures started by women entrepreneurs with every passing five years starting from 1985 till 2015. It is because of many socio-economic factors like spread of knowledge that women can also be an important economic agent of nation, the acceptance of society towards women entrepreneurs, rising inflation, efforts of government, spread of education among women and due to peer effect.

Second fact is, massive growth of women owned businesses in the year 2011-2015 indicates that the combined efforts of government and society is enabling women to think out of the box and take up the charge of one's own destiny by starting business establishments.

Third and most vital fact is 52 per cent (a sum of businesses established from before 1985 to 2010) of women owned businesses are established for more than five to ten year now and still chasing the path of success indicates the sustainability women owned business ventures have.

It is observed that although women face interventions from family about establishing a business venture of self, society is always open to those who possess ideas and are ready to provide something unique to customers. This approach of society has motivated women to continuously come forward in the state of Gujarat to give shape to their entrepreneurial ideas 
and be resourceful to society. Therefore more than 52 per cent women entrepreneurs are observed pursuing their entrepreneurial gusto in the State for more who have business establishments having an establishment for more than 6 years now (established in 2010 or before).

\section{B. Industry}

Statistics reveal the ease of starting business into service sector by the respondents as massive 56 per cent of respondents are observed having their business being run in services sector. Table 4.15 and Chart 4.14 represents that 37 per cent of respondents have their business ventures in manufacturing sector and 7 per cent of respondents have their establishment in both the sectors.

TABLE 4.15

Type of industry

\begin{tabular}{|c|c|}
\hline Type of Industry & Frequency \\
\hline Manufacturing & 148 \\
\hline Service & 224 \\
\hline Both & 29 \\
\hline Total & 401 \\
\hline
\end{tabular}

Primary Source 


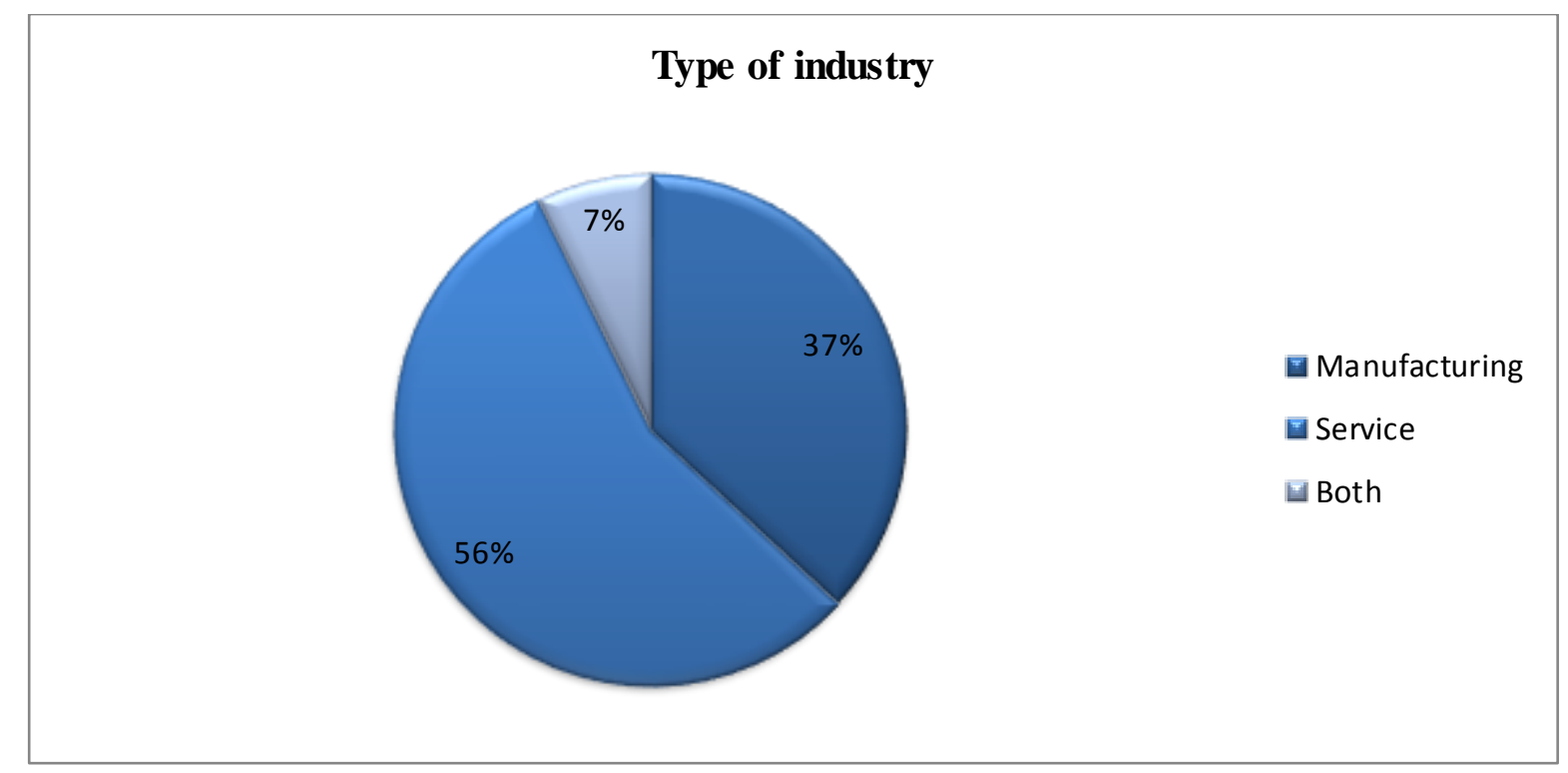

Primary Source

\section{CHART 4.14}

Pie Chart to represent type of industry

There may be a difference visible between women entrepreneurs spread in manufacturing and services sector but it should not be ignored that a whopping 44 per cent (a sum of businesses in manufacturing sector and both the sectors) are into manufacturing sector. This is a good sign as most of the studies have revealed that women entrepreneurs are less active in manufacturing sector but in case of Gujarat women entrepreneurs are observed being fairly active in manufacturing sector in MSMEs.

High participation of women entrepreneurs in service, manufacturing or multiple sectors portrays immense flourishing opportunities which gives rise to not only existing form of businesses, like retail shops, home based businesses, micro manufacturing units etc, but various new forms of businesses too like image building institutions, event management firms, businesses to provide tour and travel services to only women customers (e.g. Travel My Ladies), micro manufacturing units opened by Self Help Group (SHG). In Sections 4.3.C and 4.3.D the various manufacturing and service business activities are further researched to study the various sectors that generally interests women to establish new enterprise. 


\section{Which kind of manufacturing activity?}

On a study of Table 4.16 and Chart 4.15, it is observed that 19 per cent of respondents are engaged in home based manufacturing of Handicraft items/Handmade Jewelry/Medicinal Products for Sale etc followed by 15 per cent respondents who are into the business of manufacturing customized cloths. Besides this other respondents belong to businesses like food processing unit (3 per cent), multiple products making (2 per cent), jewelry merchant (gold or diamond jewelry production) (2 per cent), heavy manufacturing industries like products like hydraulics, machinery goods etc ( 2 per cent) and spices production (0.2 per cent).

TABLE 4.16

Type of manufacturing activity

\begin{tabular}{|l|c|}
\hline \multicolumn{1}{|c|}{ Type of Manufacturing Activity } & $\begin{array}{c}\text { Frequen } \\
\text { cy }\end{array}$ \\
\hline Food Processing Unit & 11 \\
\hline Making Customized Clothing/Textiles Manufacturing & 60 \\
\hline Spices Manufacturing & 1 \\
\hline Multiple Product Lines & 9 \\
\hline $\begin{array}{l}\text { Home based Manufacturing Handicraft items/Handmade Jewelry/Medicinal } \\
\text { Products for Sale }\end{array}$ & 78 \\
\hline Jewelry Merchants (Diamond/Gold/Silver) & 10 \\
\hline Machinery Goods / Engineering Products & 8 \\
\hline Total & 177 \\
\hline System & 224 \\
\hline & 401 \\
\hline
\end{tabular}

Primary Source 


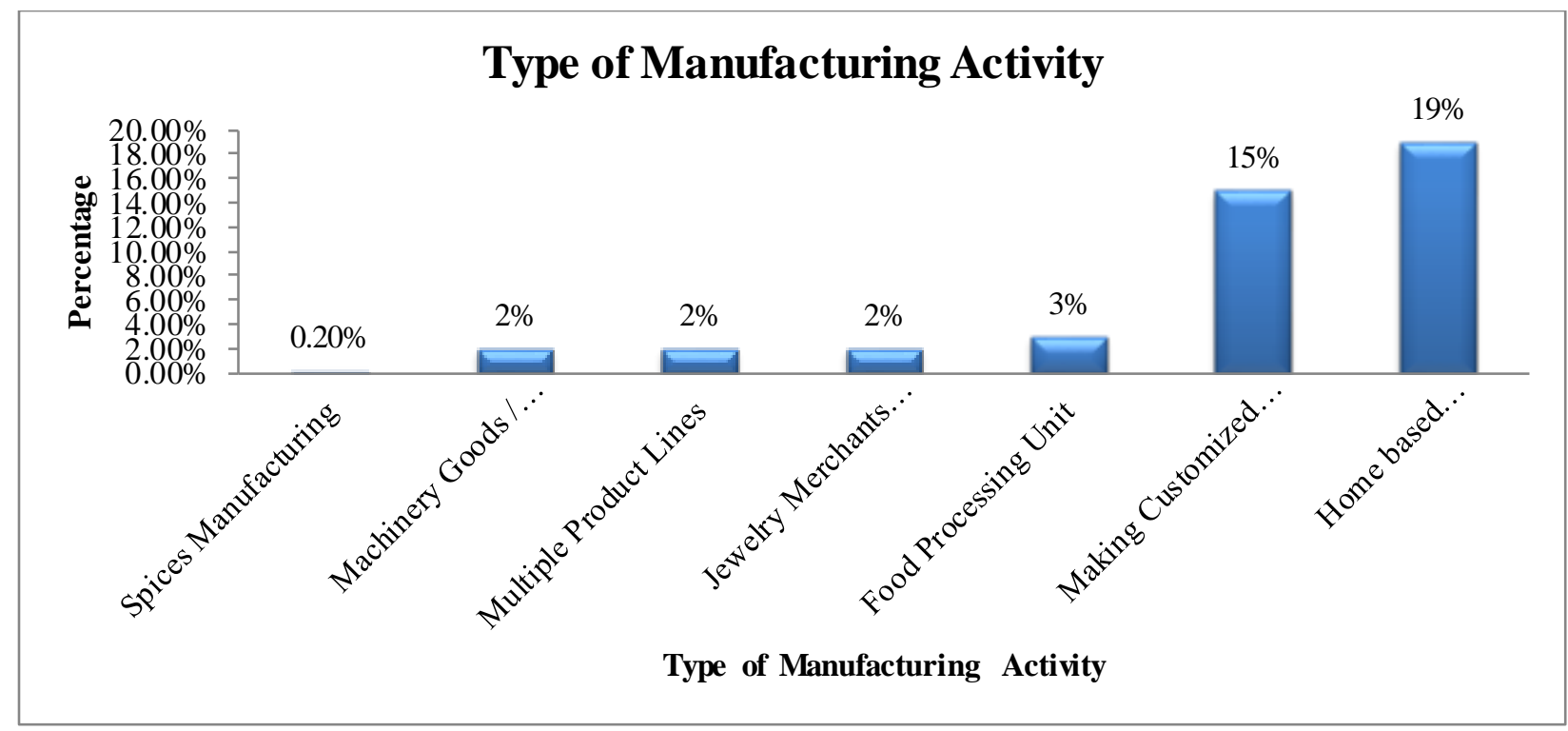

Primary Source

CHART 4.15

Bar Chart to represent type of manufacturing activity

This statistics reveal that women owned businesses have successfully carved out their niche in home based businesses and customized cloths manufacturing. The logic behind this is home based businesses gives women an opportunity to balance between home and business responsibilities and enjoy the benefit of being economically independent.

Women in Gujarat have grown steadily in manufacturing of customized clothing business due to increased demand of unique designer clothing among people in Gujarat as a result of increased disposable income.

The non-traditional businesses for women, like exploring in manufacturing of heavy industries, gold or diamond jewelry manufacturing, spices production range in Gujarat, needs to be nurtured further. 


\section{Which kind of service activity?}

In comparison to manufacturing industry, service industry finds much wider classification of options available to start business ventures owned by women owners as shown in Table. 4.17 and Chart 4.16. Mostly respondents are observed owning a retail business (33 per cent). This has huge spread in Gujarat. This is because of ease of starting this form of business. In many retail businesses the goods are brought to the retail unit on credit and hence there is not any need of investment on goods while you own a retail shop. Hence retail business gives impetus to the entrepreneurial thought of women and helps in transforming it to veracity.

TABLE 4.17

Type of service activity

\begin{tabular}{|l|c|}
\hline \multicolumn{1}{|c|}{ Type of Service Activity } & Frequency \\
\hline Professional Beauty \& Wellness Salon & 37 \\
\hline Hotel/Catering Services/Restaurant Franchise/Cooking Classes & 7 \\
\hline Retail Store/Wholesale trading/Home based retail & 131 \\
\hline Consultancy Services & 11 \\
\hline Multiple Business Activity & 15 \\
\hline Agency of Goods/Services & 13 \\
\hline Pre School / IT Learning Centers/ Hobby Centers / Coaching Institutes & 24 \\
\hline Tour and Travel Services & 4 \\
\hline Computer Hardware / Software Solutions / IT Services & 2 \\
\hline Event Management Firm & 6 \\
\hline Photo and Video Studio & 4 \\
\hline Total & 254 \\
\hline
\end{tabular}

Primary Source 


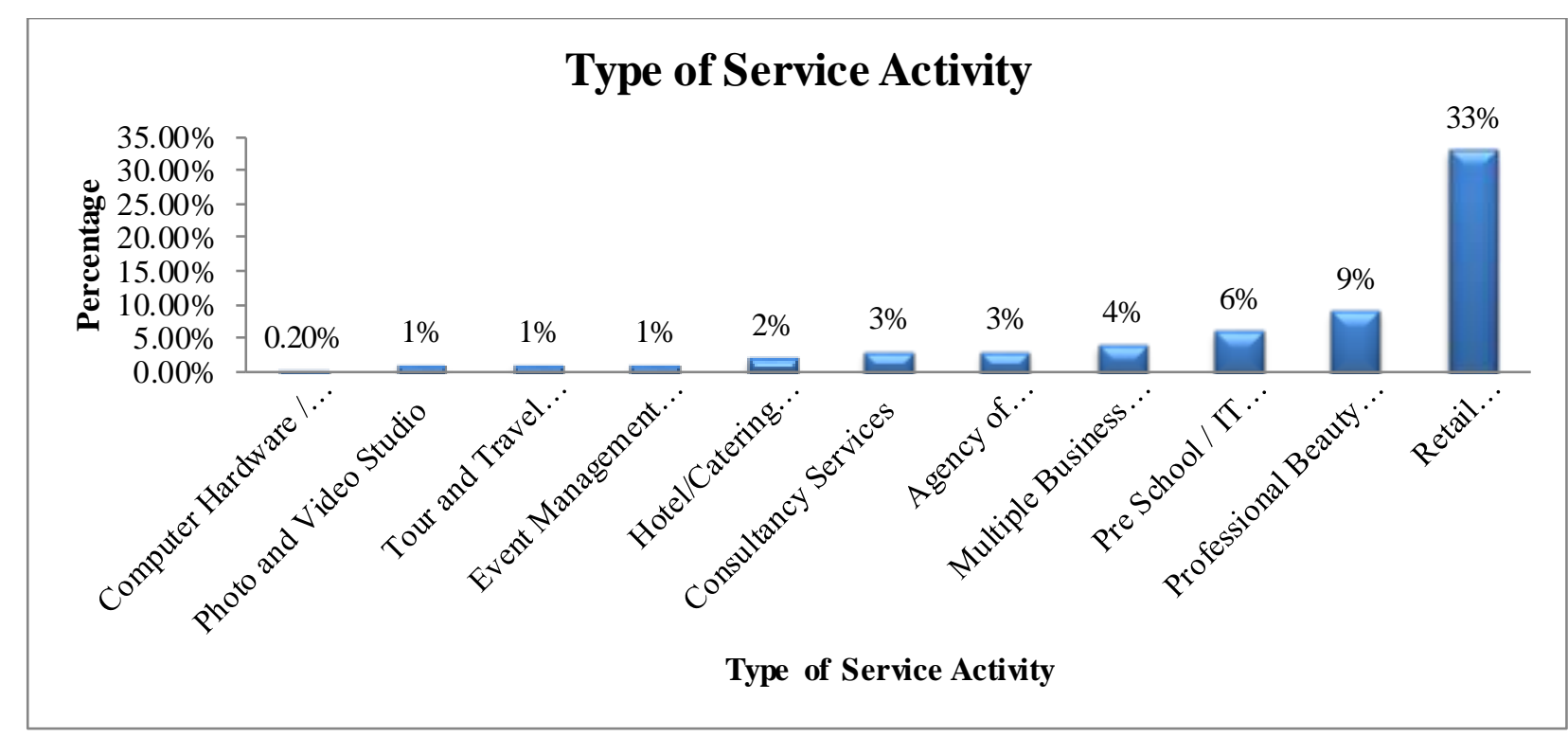

Primary Source

CHART 4.16

Bar Chart to represent type of service activity

Rest of the business activities in service industry are observed to be professional beauty and wellness salon (9 per cent), Pre School / IT Learning Centers/ Hobby Centers / Coaching Institutes (6 per cent), involved into multi-business activities (4 per cent), consultancy services and being an agent to specific product like Amway, Oriflamme, Ektra both 3 per cent each, travel and tour planning business, event management and photography based services 1 per cent each followed by IT solution business (0.5 per cent). As per the current study, it is observed that in Gujarat other form of businesses in service sector has not been exploited at par with retail businesses. Hence there lies huge scope for the policy-makers to provide training to women entrepreneurs to start a business venture in rest of the businesses in service sector.

\section{E. Size of the business}

As per the conclusion of many existing research, Gujarat also finds maximum existence of women owned businesses in micro enterprises (82 per cent) followed by a lot of difference small enterprises (15 per cent) and medium enterprises (3 per cent) as shown in Table 4.18 and Chart 4.17. 
TABLE 4.18

Size of business

\begin{tabular}{|l|c|}
\hline \multicolumn{1}{|c|}{ Size of business } & Frequency \\
\hline Micro & 327 \\
\hline Small & 61 \\
\hline Medium & 13 \\
\hline Total & 401 \\
\hline
\end{tabular}

Primary Source

\section{Size of business owned by women}

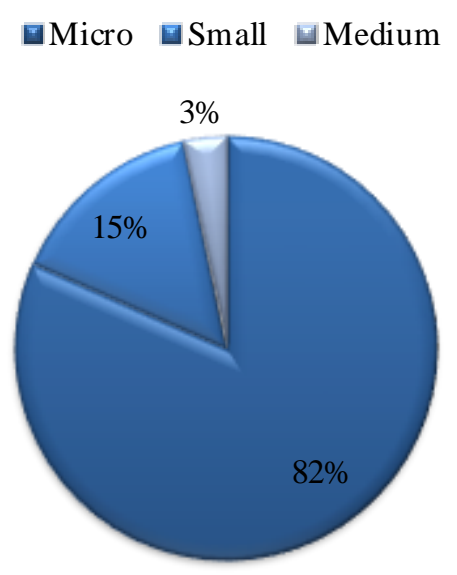

Primary Source

CHART 4.17

Pie Chart to represent percentage wise distribution of size of women owned business

This confirms the immense dependence of micro enterprises on the entrepreneurial women in the state of Gujarat. It is observed due to the fact that micro enterprises are less capital and labor intensive and becomes a dependable option for those women who are looking for opening a business venture of their own but lack capital to invest.

This statistics also finds the gap existing between the women entrepreneurs and small and medium enterprises. Government initiatives like 'Women Industrial Park' at Sanand (Gujarat) have high potential to encourage women to grow and establish their businesses to small and medium enterprises. 


\section{E.1. Relationship between size of business and age of women entrepreneurs}

$H 1_{0}$ - Size of the business and age of women entrepreneurs are independent.

H1 - Size of the business and age of women entrepreneurs are not independent.

A chi-square test of independence was calculated comparing the frequencies of size of business owned by respondents and age of respondents. A significant interaction is found $\left(\chi^{2}\right.$ $=23.73, \mathrm{p}<0.05)$. It leads to the conclusion that size of business and age are not independent to each other in the state of Gujarat. Table. 4.19 represent that there is significant shift from micro to small and medium enterprises with the increasing age among the women entrepreneurs of the state. It is due to higher need of achievement with increasing age. Hence, in this case null hypothesis is rejected.

TABLE 4.19

Table to represent the relationship between age of women entrepreneurs and size of their businesses

\begin{tabular}{|l|r|r|r|r|}
\hline \multirow{2}{*}{ Age } & \multicolumn{3}{|c|}{ What is the size of your business? } & \multirow{2}{*}{ Total } \\
\cline { 2 - 4 } & \multicolumn{1}{|c|}{ Micro } & \multicolumn{1}{c|}{ Small } & Medium & \\
\hline Below 25 & 20 & 5 & 0 & 25 \\
\hline $25-35$ & 124 & 9 & 3 & 136 \\
\hline $36-45$ & 108 & 28 & 4 & 3 \\
\hline $46-55$ & 58 & 10 & 3 & 71 \\
\hline Above 55 & 17 & 9 & 13 & 29 \\
\hline & 327 & 61 & 301 \\
\hline
\end{tabular}

Primary Source

\section{E.2. Relationship between size of business and education level of women entrepreneurs}

H2 $2_{0}$ - Size of the business and education level of women entrepreneurs are independent.

H2 - Size of the business and education level of women entrepreneurs are not independent. 
A Chi-square test of independence is calculated by comparing the frequencies of size of business of the respondents and education level of respondents. A significant interaction is found $\left(\chi^{2}=21.85, p<0.05\right)$. Hence, in this case null hypothesis is rejected.

This depicts dependence of size of business of women entrepreneurs on their education level. Table 4.20 illustrates that micro sector observes participation of women entrepreneurs who are illiterate to those who education up to post graduation. Education level among women entrepreneurs of small and medium sectors observes no participation at all from illiterate women and in micro sector women of lower education level gets limited. Small and medium enterprises observe maximum participation from those women entrepreneurs who have a minimum education level of graduation or beyond. This is due to two fold effects: - 1) there is need of enhanced knowledge with increasing size of businesses which leads women to pursue higher education and 2) higher education generates in individual an elevated need of achievement and hence they may start-up their venture as a micro enterprise but eventually aims to grow their businesses to small and medium enterprises.

It is also highlighted that micro sector has immense participation of women entrepreneurs mostly of those whose education level is minimum graduation and beyond but micro sector becomes a prospective opportunity for women entrepreneurs from lower education backgrounds.

TABLE 4.20

Table to represent the relationship between education level of women entrepreneurs and size of their businesses

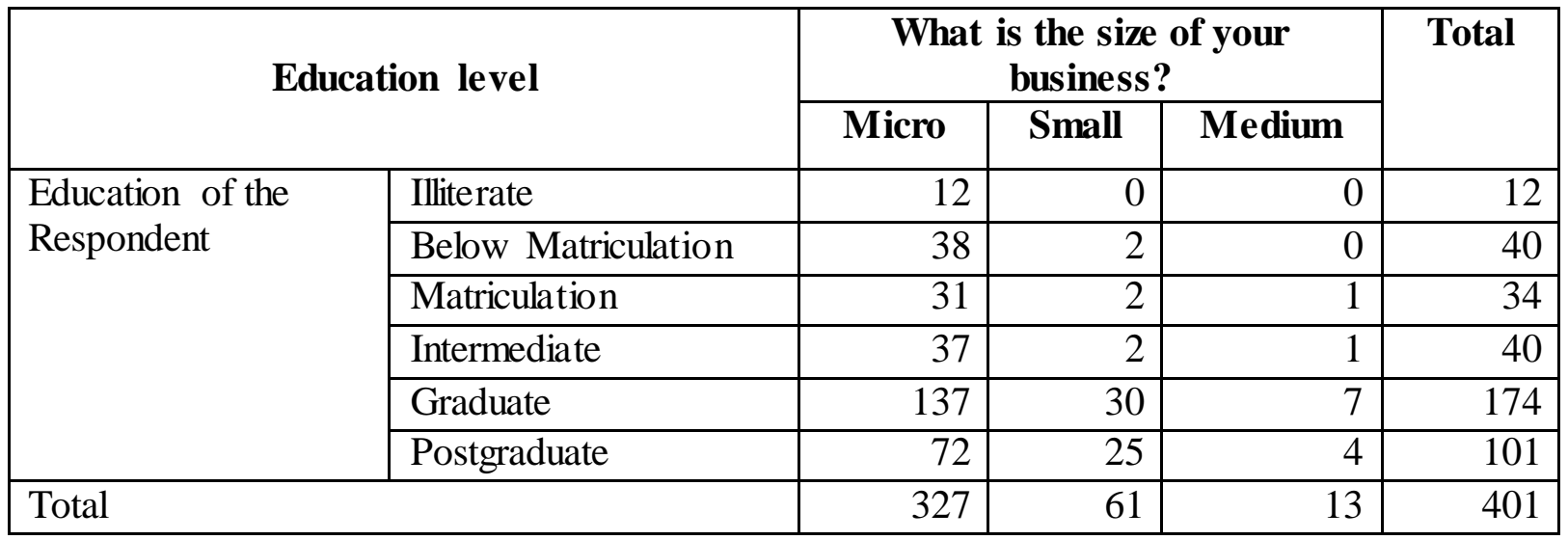

Primary Source 


\section{E.3. Relationship between size of business and husband's occupation}

H3 $3_{0}$ - Size of the business and hus band's occupation of women entrepreneurs are independent.

H3 - Size of the business and husband's occupation of women entrepreneurs are not independent.

A Chi-square test of independence is calculated by comparing the frequencies of size of business of respondents and husband's occupation of respondents. There does not exist any significant interaction $\left(\chi^{2}=16.14, \mathrm{p}>0.05\right)$. This depicts independence of size of business of respondents and husband's occupation of respondents in the state. Table 4.21 illustrates non existence of significant relationship between size of business and husband's occupation.

In this case null hypothesis is accepted.

TABLE 4.21

Table to represent the relationship between husband's occupation and size of businesses

\begin{tabular}{|c|c|c|c|c|c|}
\hline & \multicolumn{3}{|c|}{$\begin{array}{l}\text { What is the size of your } \\
\text { business? }\end{array}$} & \multirow{2}{*}{$\begin{array}{l}\text { Tota } \\
\text { l }\end{array}$} \\
\hline & & Micro & Small & Medium & \\
\hline \multirow{6}{*}{$\begin{array}{l}\text { Husbands } \\
\text { Occupation }\end{array}$} & Business & 150 & 37 & 9 & 196 \\
\hline & $\begin{array}{l}\text { Private or Government } \\
\text { Service }\end{array}$ & 91 & 8 & 1 & 100 \\
\hline & Freelance Professional & 6 & 0 & 0 & 6 \\
\hline & Professional with own firm & 15 & 5 & 2 & 22 \\
\hline & Others & 12 & 1 & 0 & 13 \\
\hline & N.A & 53 & 10 & 1 & 64 \\
\hline \multicolumn{2}{|l|}{ Total } & 327 & 61 & 13 & 401 \\
\hline
\end{tabular}

Primary Source 


\section{F. Number of such businesses owned}

Table 4.22 and Chart 4.18 show the prevalence of respondents in owning 1 business (84 per cent) over those who own and run 2 business activities (10 per cent), 3 business activities ( 4 per cent) and more than 3 activities (2 per cent) at a time.

TABLE 4.22

Number of businesses owned

\begin{tabular}{|l|c|}
\hline How many such businesses do you own? & Frequency \\
\hline One & 336 \\
\hline Two & 42 \\
\hline Three & 16 \\
\hline More than 3 & 7 \\
\hline Total & 401 \\
\hline
\end{tabular}

Primary Source

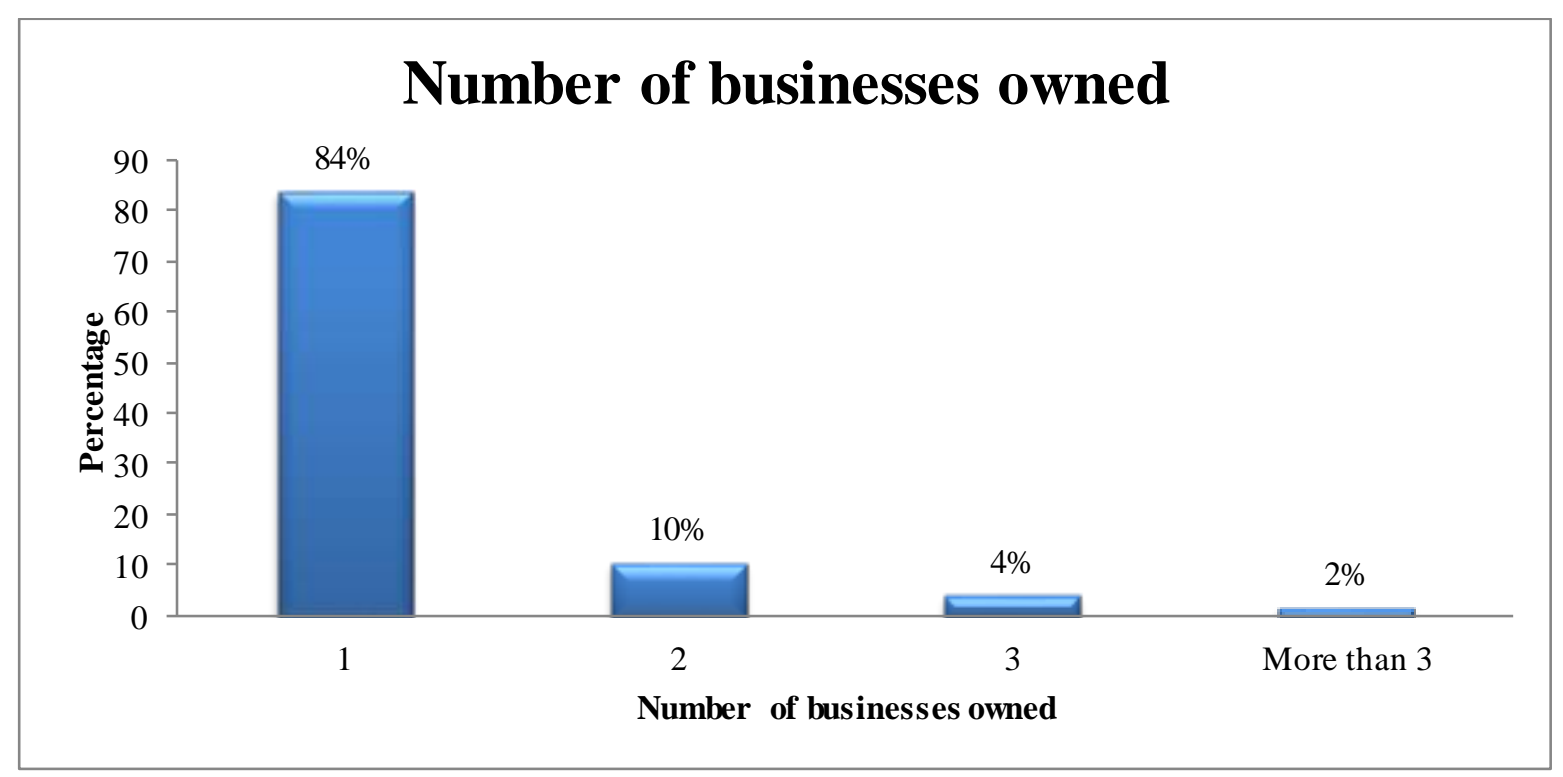

Primary Source

CHART 4.18

Bar Chart to represent number of businesses owned by individual women entrepreneurs 
This is owing to the fact that women are still taking baby steps to sink in the entrepreneurial attitude where entrepreneurs are continuously seeking opportunities to grow in business. The justification also lies in the statistics of 'Micro, small and medium enterprises' where it is identified that maximum woman entrepreneurs have set up their ventures in micro sector hence indicates the basic step towards business that woman entrepreneur is advancing. These women are middle or lower middle class women entrepreneurs hence can afford to invest their money and time towards one business at a time.

\section{G. If business is registered or not?}

Amazing fact revealed in Table 4.23 and Chart 4.19 is that more than half of the respondents' i.e.53 per cent confirm that their business venture is registered against 47 per cent of respondents who still have to register their business.

This result is against the findings of researches which claim that women owned businesses are mostly unregistered. This shows that women owned businesses increasingly understand the importance of business being registered.

TABLE 4.23

Table to represent the number of women owned registered units

\begin{tabular}{|l|c|}
\hline Is your business registered? & Frequency \\
\hline Yes & 214 \\
\hline No & 187 \\
\hline Total & 401 \\
\hline
\end{tabular}

Primary Source. 


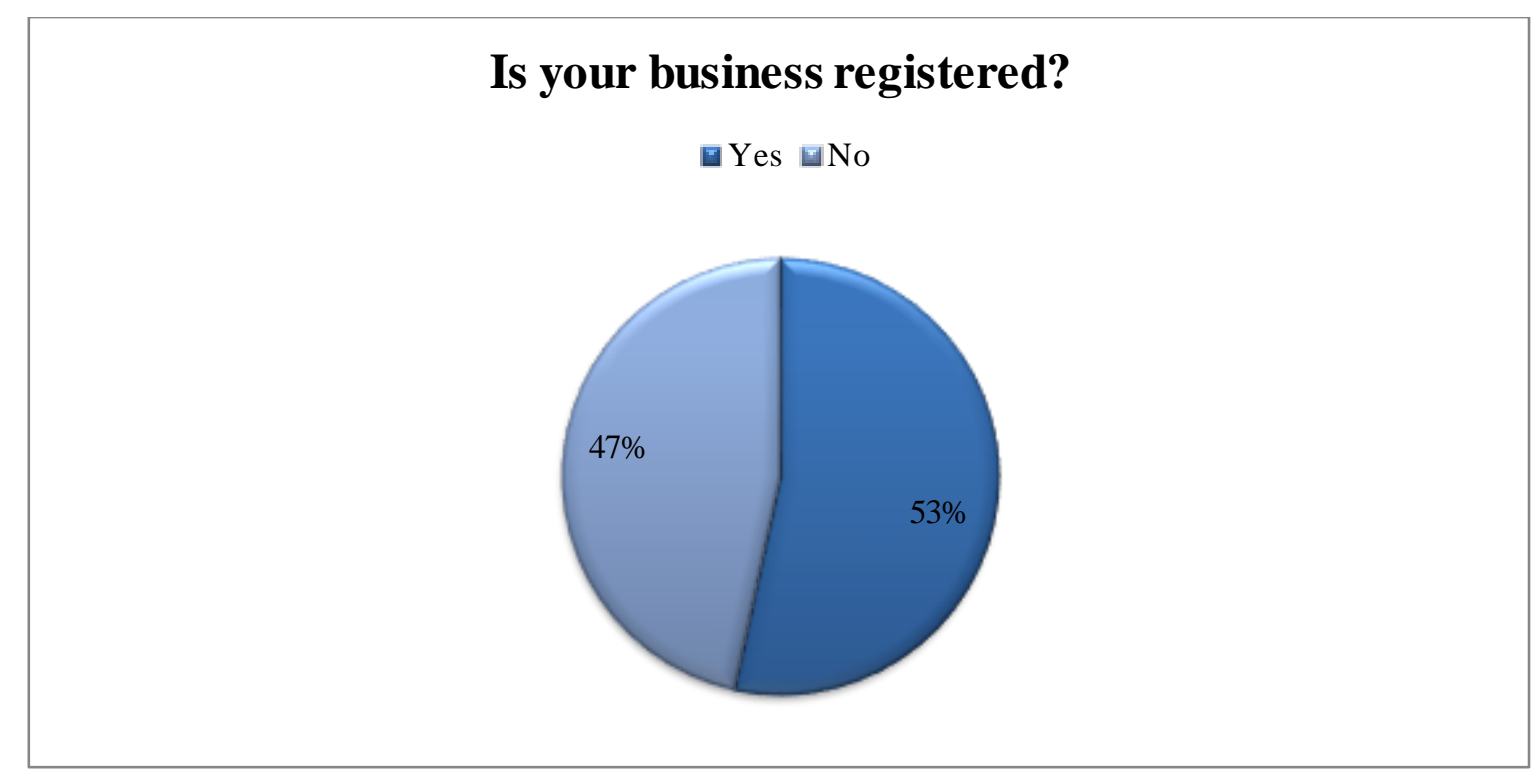

Primary Source

CHART 4.19

Pie Chart to represent number of women owned registered units

It was observed that in service sector women owned businesses are mostly established in retail sector. It was observed by the researcher during the survey that in retail sector businesses are usually registered under Shops and Establishment Act of respective municipality corporation. This is also observed with entrepreneurs who own businesses of customized cloth manufacturing, food processing businesses, hotel and restaurant businesses, diamond jewelry manufacturing businesses, and those beauty salon businesses which are established in shop establishments. On the contrary home based businesses, newly established ventures irrespective of industry have avoided getting registered to get $r$ id of tax and other impositions.

\section{H. Seed capital}

As per the finding of Table 4.24 and Chart 4.20 this is highly surprising to know that women entrepreneurs have mostly been relying on personal savings as seed capital while starting a business (65 per cent) or borrowing from family/relatives (27 per cent). It is followed by bank credit (16 per cent), Local Creditors (3 per cent) and other sources (2 per cent). 
TABLE 4.24

Table to represent the source of seed capital

\begin{tabular}{|l|c|}
\hline Source of Seed Capital & N \\
\hline Personal Savings & 262 \\
\hline Borrowing from family/relatives & 107 \\
\hline Bank Credit & 63 \\
\hline Local Creditors & 13 \\
\hline Other Sources & 10 \\
\hline
\end{tabular}

Primary Source

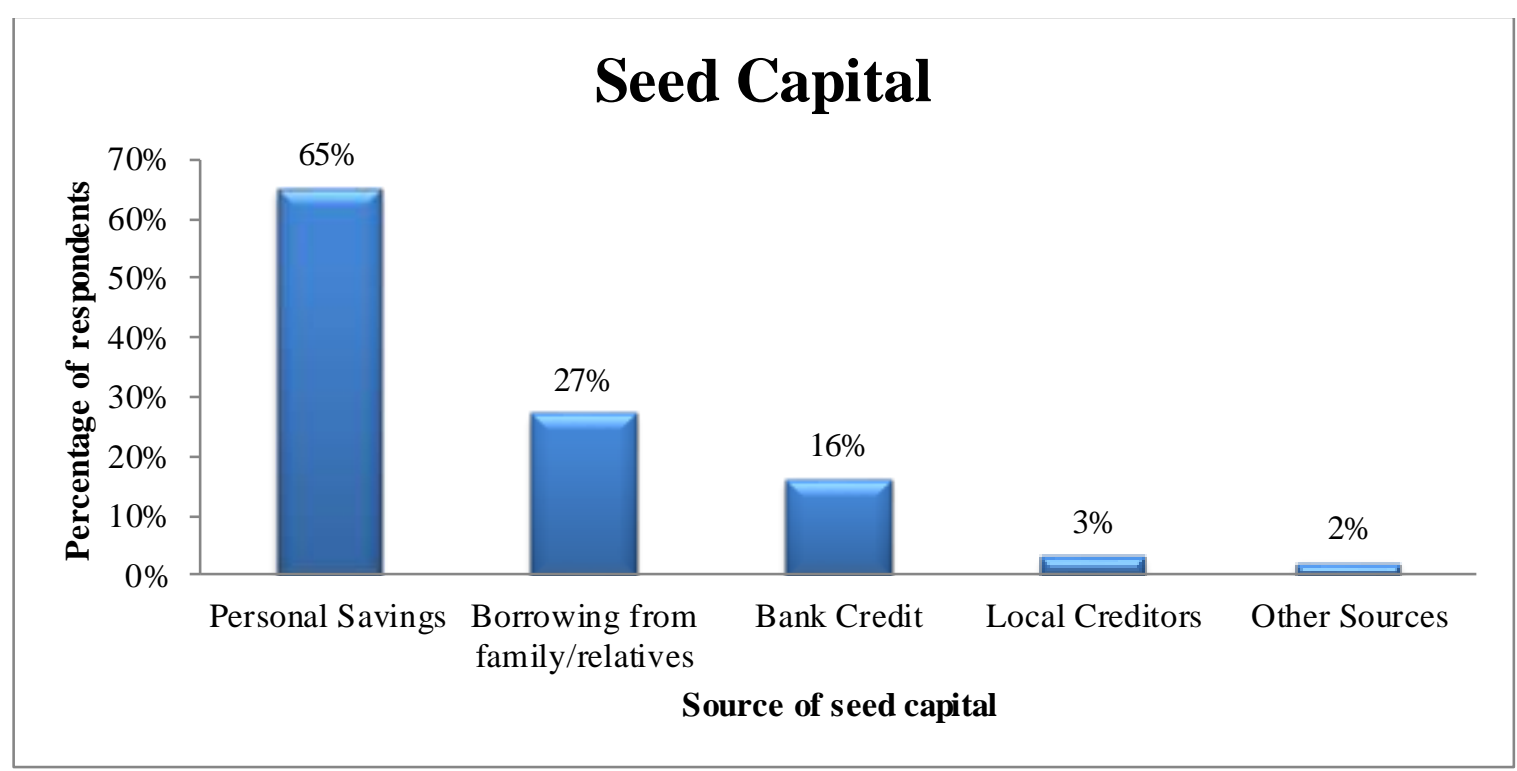

Primary Source

CHART 4.20

Bar Chart to represent the source of seed capital

Other sources of seed capital reveal support coming for nascent women entrepreneurs in form of borrowing from friends, companies extending help under their CSR initiatives to give financial support to marginal entrepreneurs or government institutions or NGOs assisting women entrepreneurs while starting the venture. It also included two different set of respondents. First, who confess that their business is credit based business which does not need initial investment. Second, encompasses those women entrepreneurs who have joined their family business hence initial investment was not required when they started venturing into this business. 
An analysis to this statistics signals that women entrepreneurs are less dependent on government or banking finance to start their ventures which are due to the fact that women entrepreneurs in general often find it difficult to access funds from government or financial bodies due to the requirements of cumbersome documents requirement and tedious procedures.

It also signals to a fact that, as women entrepreneurs are more dependent on their personal savings to start the business, it is due to the general perception of people to not indulge in tedious procedures of banks and not to burden self with heavy repayment obligations in form of installments. This is becoming a general perception and a hindrance for Gujarat economy as prospective entrepreneurs will start their ventures only when they have saved enough personal savings to practice their entrepreneurial ideas. For a middle class person saving in current scenario becomes difficult due to high inflation and limited source of income, hence it is impossible for them to give shape to their business ideas due to insufficient savings.

\section{How easy was it for you to establish your business?}

When asked about 'How easy has it been to start a business?' 41 per cent of respondents be in agreement about it being slightly difficult, 28 per cent of respondents concur that it has been difficult, 17 per cent of respondents belief it to be moderate and 14 per cent of respondent considers it to be very easy as visible in Table 4.25 and Chart 4.21 .

TABLE 4.25

Table to represent the ease to start a business for women entrepreneurs

\begin{tabular}{|l|c|}
\hline \multicolumn{1}{|c|}{ How easy was it for you to establish your business? } & Frequency \\
\hline Very Easy & 54 \\
\hline Moderate & 68 \\
\hline Slightly difficult & 166 \\
\hline Very difficult & 113 \\
\hline Total & 401 \\
\hline
\end{tabular}

Primary Source 


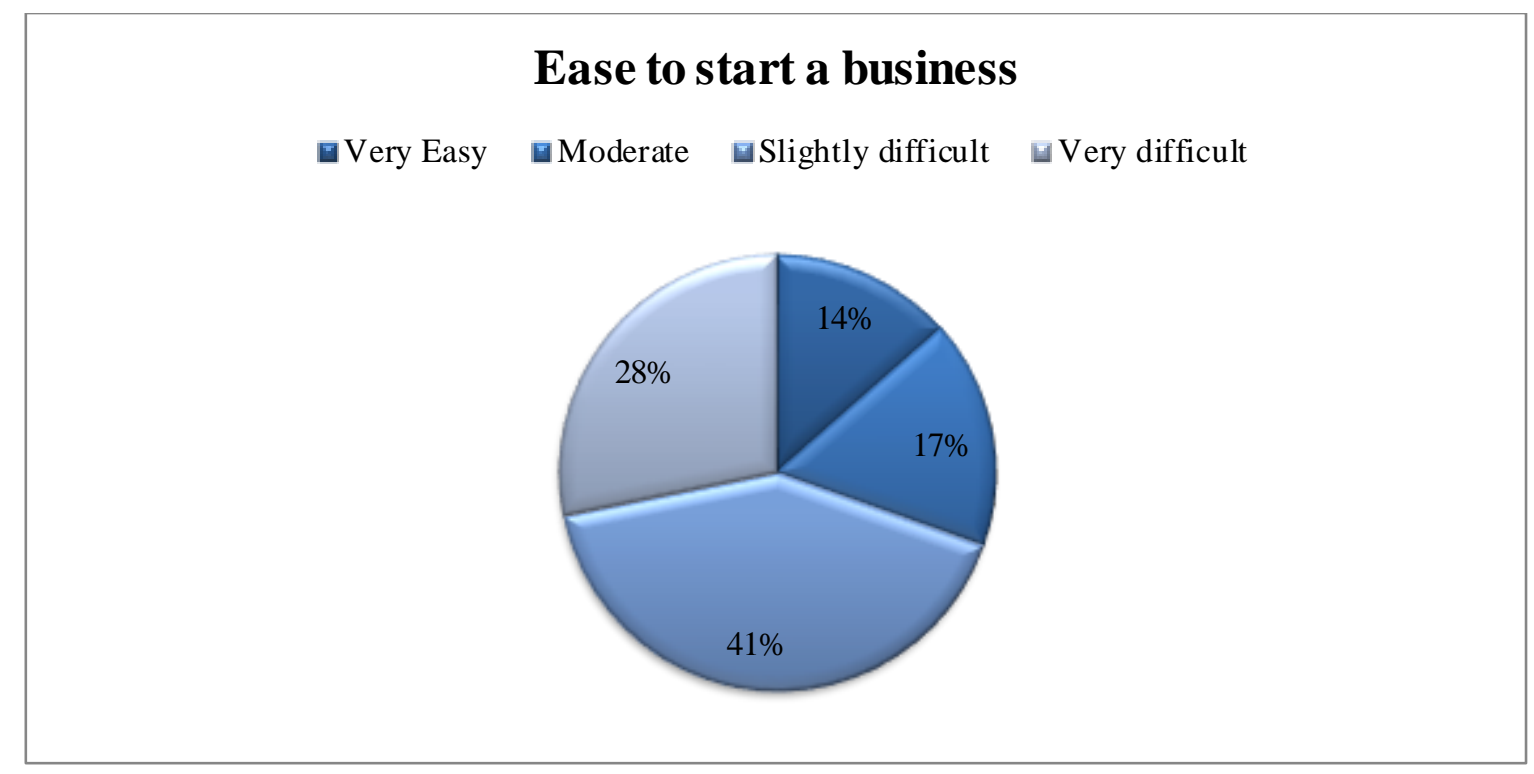

Primary Source

CHART 4.21

Pie Chart to represent the ease to start a business for women entrepreneurs

The general belief in case of who responds that running a business have been slightly difficult' and 'very difficult' is that business needs individual entrepreneur's total concentration, time, skills, business aptitude and patience to survive in the market. There does not exist any special hurdle that deters women to pursue the dream of entrepreneurship.

\section{J. Have you ever attended an Entrepreneurship Development Programme (EDP)?}

When respondents are asked if they have attended any 'Entrepreneurship Development Programme' at any point of time for their business, as shown in Table 4.26 and Chart 4.22, majority (76 per cent) of respondent concurs that they have not undergone any such training while 24 per cent of them confess to have undergone EDP to either at the start of business or in between for the growth of the business. 
Table to represent 'Have you ever attended EDP?'

\begin{tabular}{|l|c|}
\hline \multicolumn{1}{|c|}{ Have you ever attended EDP? } & Frequency \\
\hline Yes & 95 \\
\hline No & 305 \\
\hline Total & 401 \\
\hline
\end{tabular}

Primary Source

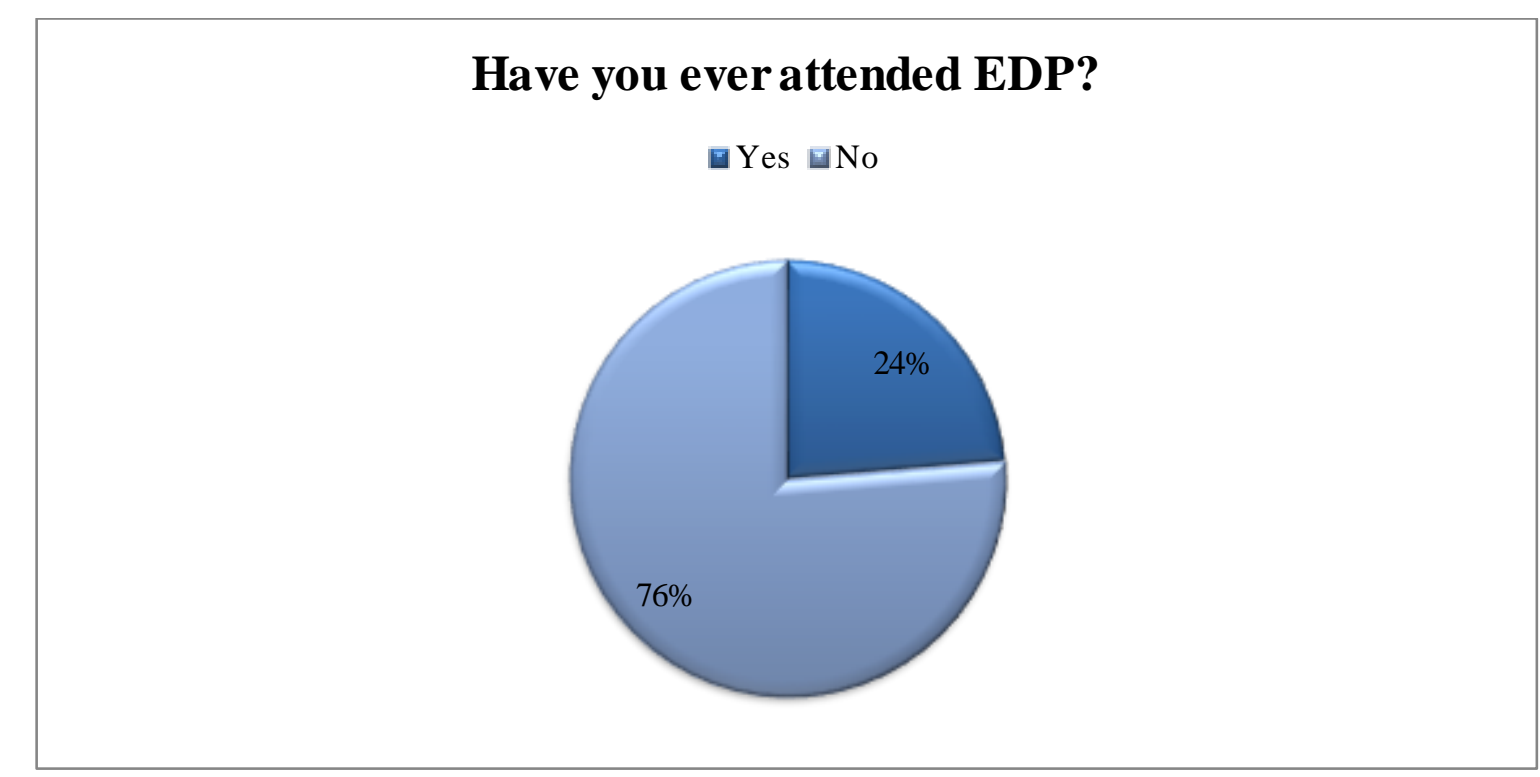

Primary Source

CHART 4.22

Pie Chart to represent 'Have you ever attended EDP?'

Those women entrepreneurs who have undertaken training and do not consider it to be an effective tool for elevating the business profit, forms potential target group for the various training institutes to be approached as it is not the case that they do not need guidance for their business growth but are unaware of promising schemes/training programmes organized by established agencies which are tailor-made according to the requirements women entrepreneurs have. 


\section{K. Is EDP beneficial for women to make them better entrepreneurs in Gujarat?}

We know that only 24 per cent of women entrepreneurs have undergone EDPs. It is interesting to add to our knowledge that 74 per cent of total respondents, irrespective of having a background of EDP, confess that EDP will definitely be fruitful for women entrepreneurs in Gujarat to guide them better for the basics and crux of business aptitude required as shown in Table 4.27 and Chart 4.23. It is due to the widespread belief that all women do not have business background. They are often in need of guidance with regard to capital, location, technical know-how, right approach to manage the business and many more. 10 per cent of respondents' belief it to be not of great importance as people learns basic skills required only from within and with experience. 16 per cent of the respondents are not in a position to answer this question because according to them if they have not undergone an EDP they cannot validate its benefits.

TABLE 4.27

Table to represent 'Is EDP beneficial for women to make them better entrepreneurs in Gujarat?'

\begin{tabular}{|l|c|}
\hline \multicolumn{1}{|c|}{$\begin{array}{c}\text { Is EDP beneficial for women to make them better entrepreneurs in } \\
\text { Gujarat? }\end{array}$} & $\begin{array}{c}\text { Frequenc } \\
\text { y }\end{array}$ \\
\hline Yes & 298 \\
\hline No & 38 \\
\hline Can't Say & 65 \\
\hline Total & 401 \\
\hline
\end{tabular}

Primary Source 


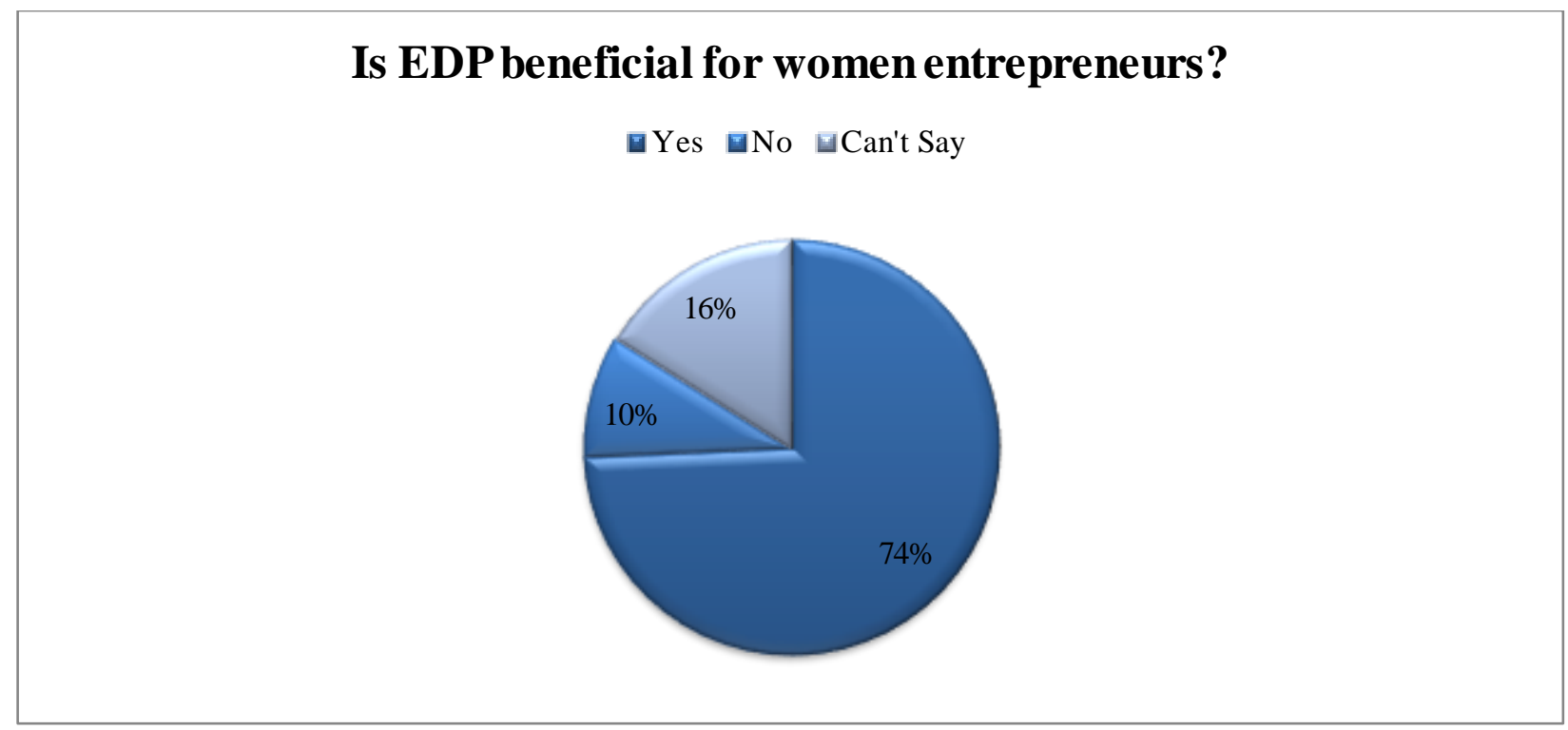

Primary Source

CHART 4.23

Pie Chart to represent 'Is EDP beneficial for women to make them better entrepreneurs in Gujarat?'

This statistics clearly depict the need women entrepreneurs have to be trained properly to be a skilled and knowledgeable entrepreneur rather than having a naïve approach when running a business.

\section{What was the growth observed in revenue generation after attending EDP?}

Further to add to our knowledge is the fact that out of these 24 per cent who have attended an EDP, as shown in Table 4.28 and Chart 4.24, 5 per cent of respondents observed agreeing upon (i) the fact that EDP has been of great value as it helped them to successfully start their business and (ii) that after attending EDP they observed an increase of 10 - 15 per cent of profit growth in their business. 4 per cent of respondents confirmed the growth they observed to be $16-20$ per cent and 21-30 per cent each. It is interesting to note that there are 3 per cent of respondents who quote that there was no change in their business profit against 1 per cent of respondents who declares the growth to be of 30-40 per cent and more. Majorly EDP has not been observed playing expected role in the state because there still lacks awareness 
among women with respect to EDPs whether organized by district level, state level or national level institutions.

TABLE 4.28

Table to represent 'Effect of EDP?'

\begin{tabular}{|l|c|}
\hline \multicolumn{1}{|c|}{ Effect of EDP? } & Frequency \\
\hline Successfully started the business after attending the program & 20 \\
\hline There was no change & 11 \\
\hline $10-15 \%$ & 21 \\
\hline $16-20 \%$ & 15 \\
\hline $21-30 \%$ & 17 \\
\hline $30-40 \%$ & 6 \\
\hline More than $40 \%$ & 4 \\
\hline N.A & 307 \\
\hline Total & 401 \\
\hline
\end{tabular}

Primary Source

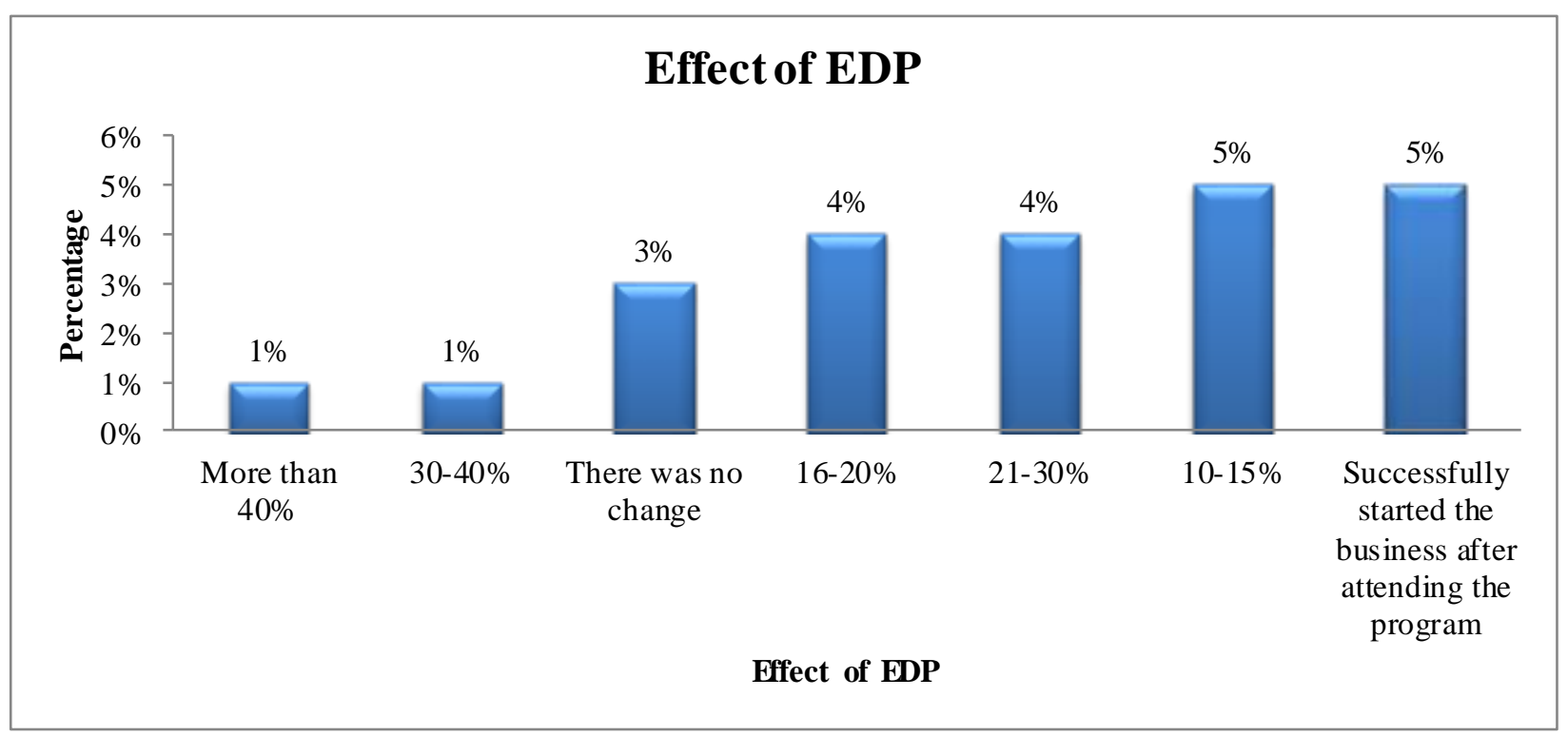

Primary Source

CHART 4.24

Bar Chart to represent 'Effect of EDP'

Since there exist set of those respondents who perceived that EDP is bringing no change to their business profits, brainstorming sessions should be focused to identify the loopholes prevailing in EDPs which these women entrepreneurs have attended. The researcher is focusing more on responses of these 3 per cent of respondents because they can help in guiding how EDP experiences can be improved for entrepreneurs in need because the 
purpose of EDP in this set of respondent is not getting served and this diminishes the whole purpose of EDP. These respondents potentially can lend a hand to us to identify the reasons due to which they could not practice the learning of EDP and hence could not observe change in the growth pattern of their business.

\subsection{Source of Continuous Support and Enabling Factors for Women Entrepreneurs -}

The aim to catalyze entrepreneurship among women in the state persistently needs to identify the crucial enabling factors, which if facilitated appropriately, may form strong base for women to excel in entrepreneurship. With this focus, the researcher makes an attempt to understand viewpoint of women entrepreneurs on factors that may prove to be enabling if facilitated to women community at large. Data pertaining to this is studied as follows in section 4.4.A \& 4.4.B.

\section{A. Source of continuous support to start and run the business}

Statistics pertaining to source of continuous support for the women entrepreneurs of Gujarat unleashed in Table 4.29 and Chart 4.25 explains that for the women entrepreneurs of Gujarat most crucial source of support is 'Family' (74 per cent), followed with a lot of difference by 'Friends' (26 per cent), 'Relatives' (12 per cent), 'Self' ( 8 per cent), 'Government Institutions' (6 per cent) and 'Financial Institutions' (4 per cent). 
TABLE 4.29

Table to represent 'Source of Continuous Support'

\begin{tabular}{|l|c|}
\hline Source of continuous support & Frequency \\
\hline Family & 296 \\
\hline Relatives & 49 \\
\hline Financial Institutions & 17 \\
\hline Government Institution & 25 \\
\hline Self & 33 \\
\hline Friends & 91 \\
\hline
\end{tabular}

Primary Source

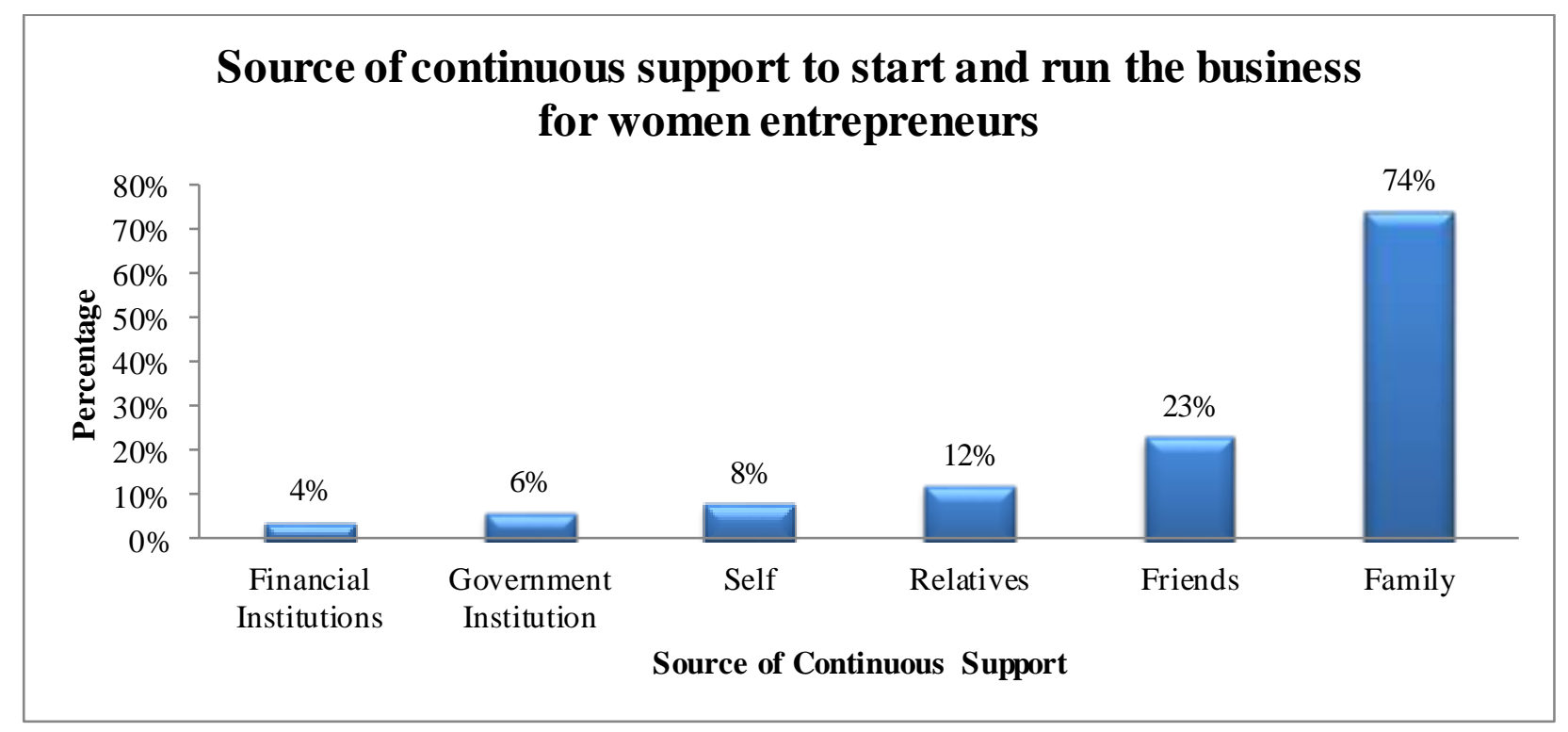

Primary Source

CHART 4.25

Bar Chart to represent 'Source of Continuous Support'

It should be noted that, in family women mostly considers husband and father. Few respondents are also found impressed by the support extended by their mother, mother-inlaw, father-in-law, brother and sisters.

Unlike any other state women in Gujarat deems husband, in-laws and parents to be great source of support for them as family extends assistance when women are at work in domestic and other responsibilities. 


\section{B. Enabling factors for women community to choose entrepreneurship as occupation:-}

Collecting data on enabling factor for women entrepreneurs of Gujarat interests the researcher to report as shown in Table 4.30 and Chart 4.26, that 83 per cent of total respondents votes in favor of 'Education' to be the vital enabling factor followed by 'Family' (77 per cent), 'Inner zeal and will power' (75 per cent), 'Finance' (62 per cent) and 'Prior Experience' (61 per cent). After this the other factors finds a gap in receiving consent on them being enabling factors like 'Location' (51 per cent), 'Training Programmes' (49 per cent), 'Society' (48 per cent), 'Infrastructure' (47 per cent), 'Government Schemes' (46 per cent), 'Competition' (43 per cent), 'Children as enabling factor' (41 per cent), 'Intermediaries' (38 per cent), 'Laws' (36 per cent), Government Policies' (35 per cent) and 'Employee' (32 per cent).

TABLE 4.30

Table to represent 'Enabling Factors' for women entrepreneurs

\begin{tabular}{|l|c|}
\hline Enabling Factors & Frequency \\
\hline Education & 332 \\
\hline Prior Experience & 245 \\
\hline Family & 310 \\
\hline Society & 194 \\
\hline Finance & 248 \\
\hline Labor & 130 \\
\hline Government Schemes & 185 \\
\hline Infrastructures & 187 \\
\hline Location & 203 \\
\hline Children as enabling factor to continue in business & 165 \\
\hline Intermediaries & 151 \\
\hline Training Programmes & 180 \\
\hline Inner zeal and Will Power & 302 \\
\hline Competition & 174 \\
\hline Government Policy & 141 \\
\hline Laws & 146 \\
\hline
\end{tabular}

Primary Source 


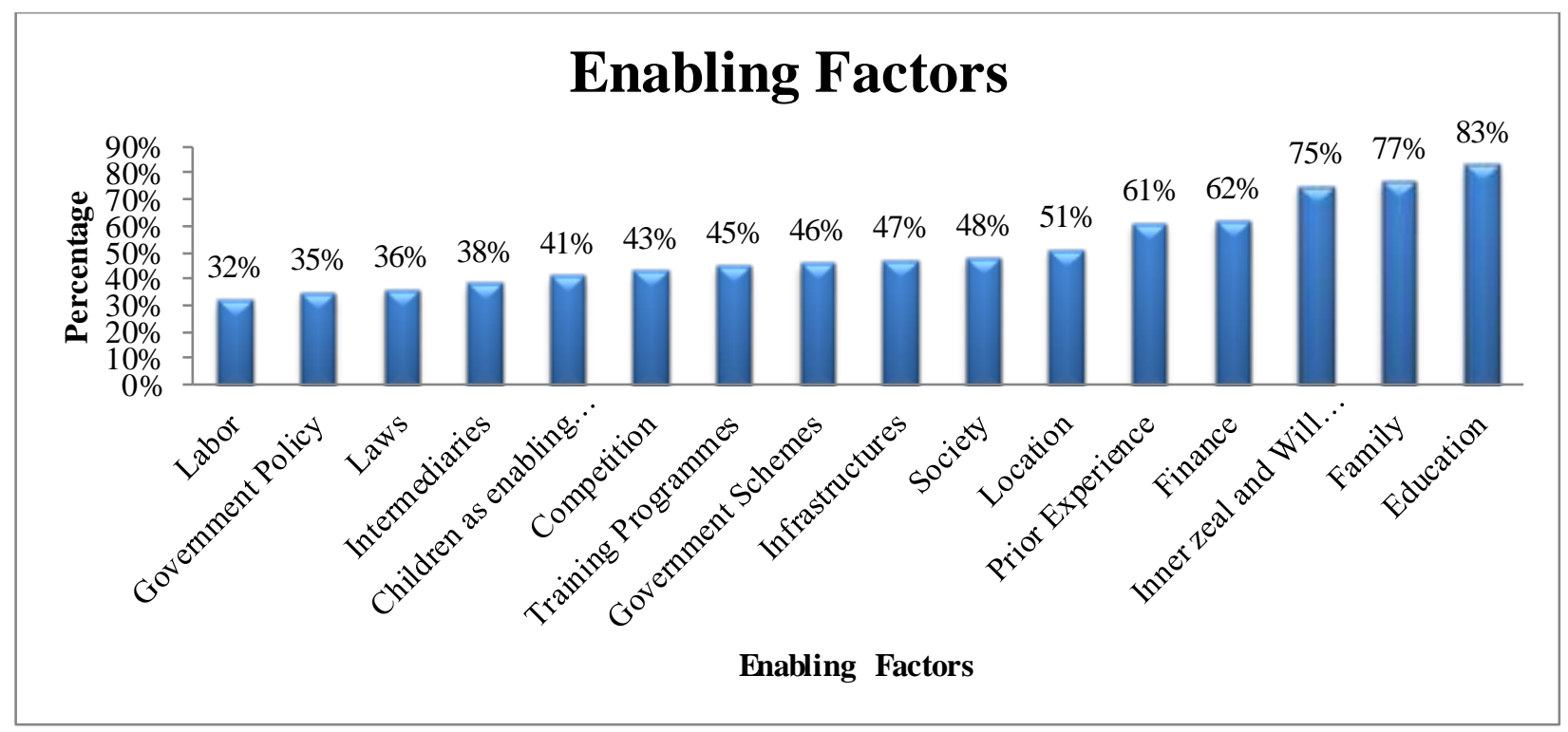

Primary Source

CHART 4.26

Bar Chart to represent 'Enabling Factors' for women entrepreneurs

It should be noted that this statistics also divulge the manifestation of women entrepreneurs' psyche which indicates the most crucial factors which persuade them to advance towards their entrepreneurial aspirations ad infinitum. It is good to add that this analysis that besides 'finance' most of the women entrepreneurs view the crucial enabling factors to be something within like 'inner zeal and will power', 'education' and 'prior experience' because these factors enable women to have a strong foothold and generates in them an approach of 'never look back' which make it possible for them to sustain in business.

Next to these factors other vital factors are location as it decides the footfall of customers; training programmes as it is instrumental in guiding novice women entrepreneurs; society as customers are part of society; infrastructure to facilitate mobility, basic amenities, safety and customer's reach and comfort; government to design policies, schemes and training programmes for the upliftment of women entrepreneurs; competition to continue innovation and bring variety in products and services range; children as enabling factor as children grows an inner spark in women to work harder to fulfill their educational and other basic amenities and to endow them with enhanced living standard; intermediaries as their timely support assures regular growth to the business; laws as it restricts or motivates the entry of new entrants into business and for framing do's and don'ts of the industry in question; 
government policies as it gives rise to various laws of the industry and lastly important factor is employee due to active involvement of their skills and intentions in business and hence to a larger extent decides the growth of the business.

\section{B.1. Relationship between education as most important enabling factor and technolological skills as a problem among women entrepreneurs -}

\section{$\mathrm{H4}_{0}$ - A belief of 'Education' as an enabling factor is independent of Lack of Technological Skills as a problem in women entrepreneurs}

\section{H4 - A belief of 'Education' as an enabling factor is not independent of Lack of Technological Skills as a problem in women entrepreneurs}

A chi-square test of independence was calculated comparing the frequencies of respondents who believe that 'Education' becomes most important enabling factor for women to run and sustain in a business venture and frequencies of women who find 'Lack of Technological Skill' as a major problem to run and sustain in business. A significant interaction is found $\left(\chi^{2}\right.$ $=9.586, \mathrm{p}<0.05)$. It indicates the non independence of a belief of 'Education as an enabling factor and 'Lack of technological skills' as a problem in women entrepreneurs in the state of Gujarat. Hence null hypothesis is rejected.

Table 4.31 elucidates that 89 per cent of those women entrepreneurs who believe that they lack technological skills also believe 'Education' to be one of the most important enabling factors for women to run a business and survive in it successfully. Rationale behind this is the idea prevailing in women entrepreneurs that education will enable women to understand and harness many existing opportunities available around in the current business environment in form of tech-enabled or virtual market which they are otherwise not able to access in absence of required education level. 
Table to represent the Relationship between Frequency of Respondents who believe Education as an Enabling Factor for Women Entrepreneurs and Respondents who face the problem of Lack of Technological Skills as an Effectual Factor

\begin{tabular}{|c|c|c|c|c|}
\hline & \multicolumn{2}{|c|}{$\begin{array}{c}\text { Enabling Factors - } \\
\text { Education }\end{array}$} & \multirow[b]{2}{*}{ Total } \\
\hline & & Yes & No & \\
\hline \multirow{2}{*}{$\begin{array}{c}\text { Technological Problems - Lack of Technological } \\
\text { Skills }\end{array}$} & Yes & 164 & 20 & 184 \\
\hline & No & 168 & 49 & 217 \\
\hline \multicolumn{2}{|l|}{ Total } & 332 & 69 & 401 \\
\hline
\end{tabular}

Primary Source

\subsection{Problems faced by Women Entrepreneurs -}

To be gender-responsive to cater to the requirement of women entrepreneurs and to allow the upcoming generation to celebrate the gender-equality in the field of entrepreneurship, identification and uprooting of problems pertaining to women entrepreneurship is the need of the hour. Researcher is making an attempt to study this with the experiences of surveyed women entrepreneurs in the sub-sections of 4.5 .

\section{A. Financial Problems}

Financial problems faced by women entrepreneurs can be bifurcated unto three sub categories: - a) general financial problems, b) problems pertaining to personal interest of women entrepreneurs in financial management and c) socio-financial problems. General financial problems are problems faced by all irrespective of gender especially in businesses and it includes problem of 'Limited working capital' and 'Delayed payment of bills to creditors'. Problems pertaining to 'Personal interest of women entrepreneurs in financial management' is the problem caused due to lack of personal interest among women entrepreneurs in handling the finances of business and these especially included problems of 
'Poor knowledge of financial management' and 'Ignorance about the banking procedures'. Here socio-financial problems are those financial problems which have erupted out of social backdrop and include problems such as 'Lack of collateral securities' and 'Negative attitude of banks towards women entrepreneurs'.

TABLE 4.32

Table to represent 'Financial Problems'

\begin{tabular}{|l|c|}
\hline \multicolumn{1}{|c|}{ Financial Problems } & Frequency \\
\hline Limited Working Capital & 288 \\
\hline Lack of Collateral Security & 144 \\
\hline Delayed payments of bills to creditors & 162 \\
\hline Negative attitude of banks towards women & 106 \\
\hline Poor knowledge of financial management & 210 \\
\hline Ignorance about banking procedures and formalities & 216 \\
\hline
\end{tabular}

Primary Source

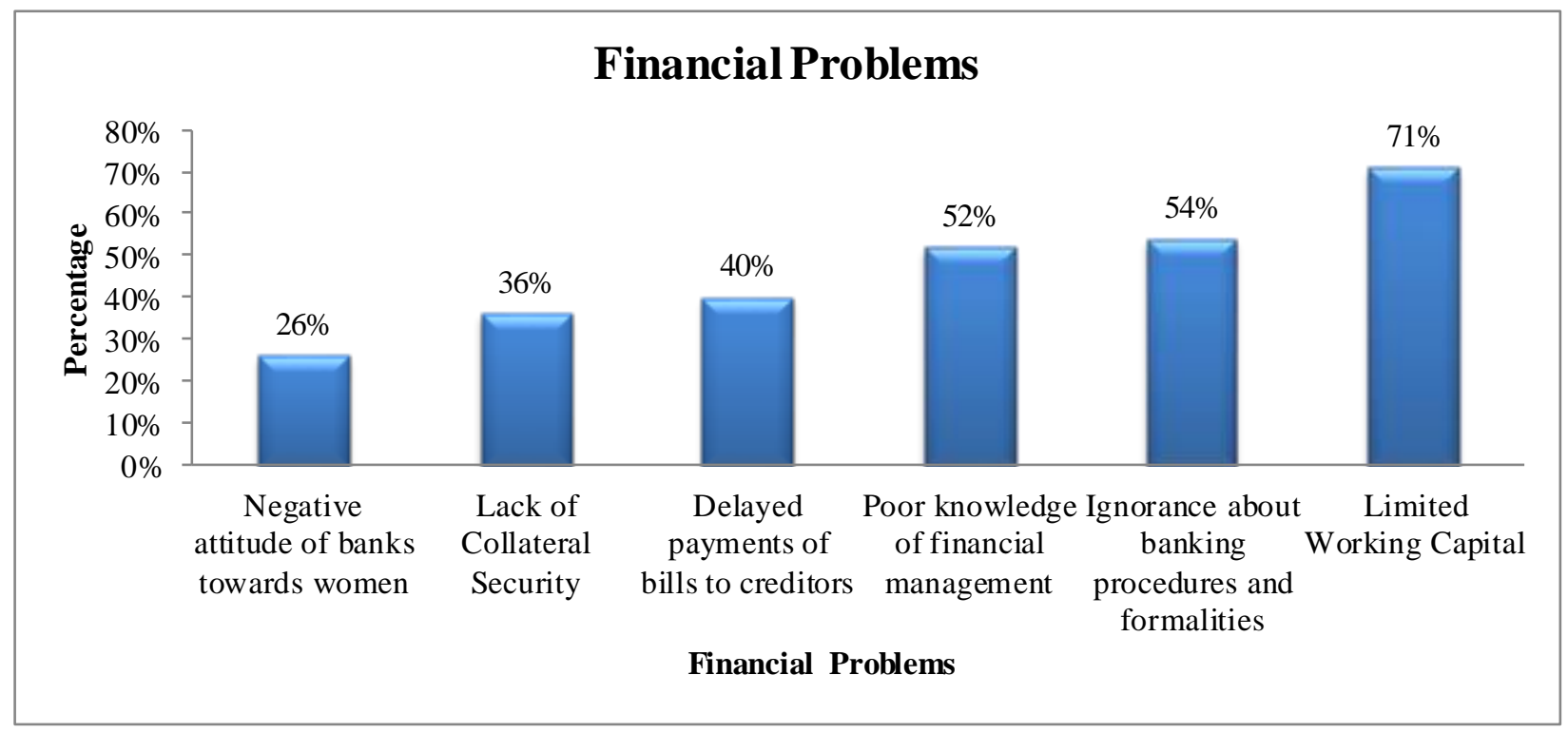

Primary Source

CHART 4.27

Bar Chart to represent 'Financial Problems' 
According to the result of current study as shown in Table 4.32 and Chart 4.27 it becomes noticeable that maximum women (71 per cent) face the problem of limited working capital (A general financial problem). It is followed by problems related to personal abilities and likings towards knowledge of managing finances i.e. ignorance towards banking procedures (54 per cent) an poor knowledge of financial management (52 per cent). Delayed payment of bills (a general financial problem) is observed to be faced by 40 per cent of respondents. This is followed by more of socio-financial problem i.e. lack of collateral security (36 per cent) and negative attitude of banks towards women (26 per cent).

It gives rise to a fact that in Gujarat women entrepreneurs face maximum of general financial problems followed by financial problems due to personal interest and at last socio-financial problems.

\section{B. Personal Problems}

Under this category researcher intends to surface the problems faced by women entrepreneurs by attitude and characteristics of self. The statistics as shown in Table 4.33 and Chart 4.28 portrays lack of leisure time to be the most important personal problem faced by 52 per cent of respondents, but at the same time women do not think that this becomes a hurdle for women to abandon their entrepreneurial pursuit. It is then observed that after this appears another important personal problem which is faced by 41 per cent of respondents i.e. avoidance of economic risk, followed by lack of risk bearing capacity with not a lot of difference i.e. 40 per cent. This underscores that 40-41 per cent of respondents' steps back when the question of bearing risk appears because as they are running small businesses with an intent to provide all facilities to their children, to make fair livelihood and to maintain a standard of living. For these things women are happy with current state and size of business and do not indulge self in any sort of risks. 
TABLE 4.33

Table to represent 'Personal Problems' faced by women entrepreneurs

\begin{tabular}{|l|c|}
\hline \multicolumn{1}{|c|}{ Personal Problems } & Frequency \\
\hline Lack of leisure time & 210 \\
\hline Lack of risk bearing capacity & 160 \\
\hline Avoidance of Economic Risk & 163 \\
\hline Lack of Self Confidence & 113 \\
\hline Absence of need of achievement & 101 \\
\hline Lack of initiative & 128 \\
\hline
\end{tabular}

Primary Source

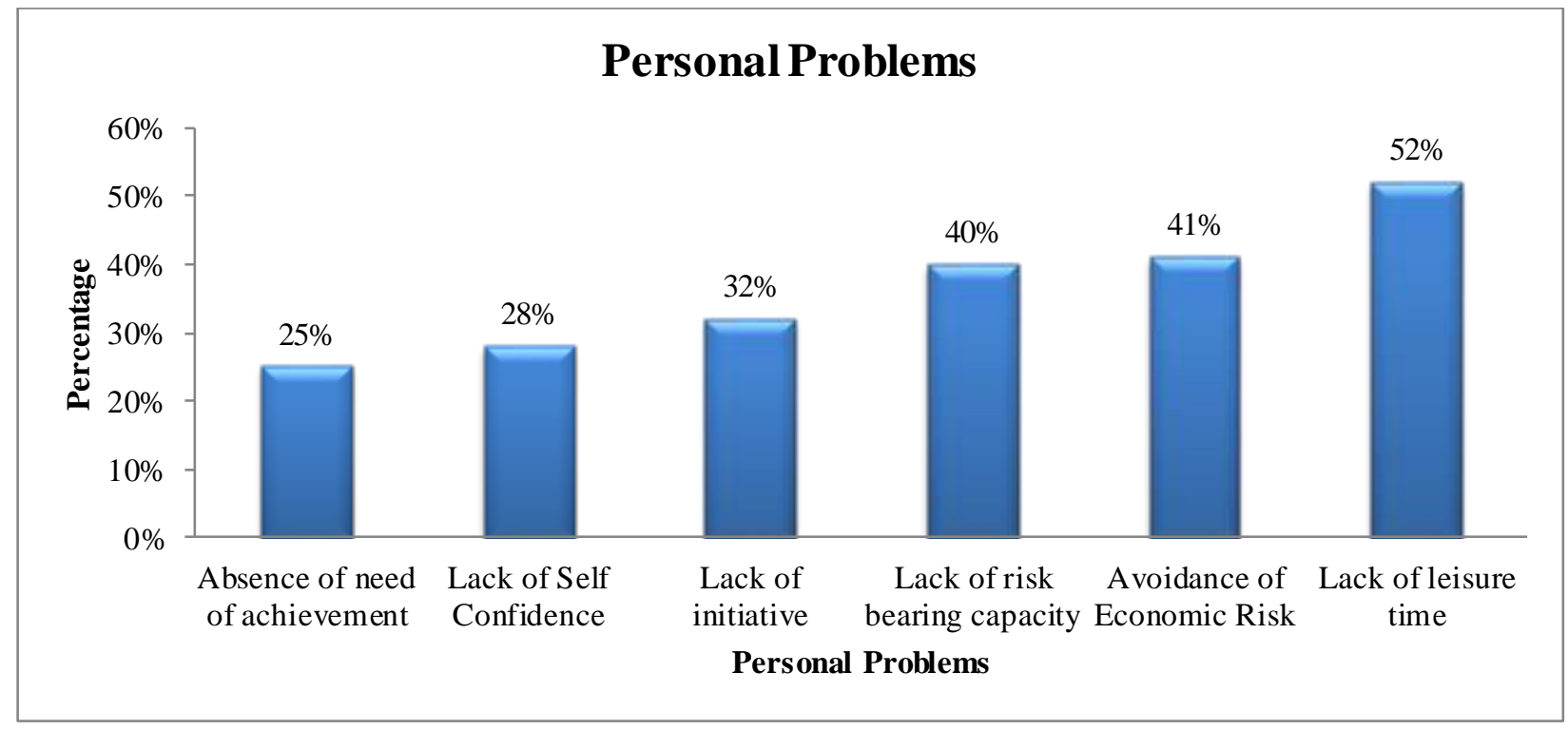

Primary Source

CHART 4.28

Bar Chart to represent 'Personal Problems' faced by women entrepreneurs

Not a lot of respondents believe but few i.e. 32 per cent that they lack initiatives that needs to be taken a lot of times, 28 per cent believe that they lack self confidence and 25 per cent believe that they lack need of achievement in themselves.

It should also be underscored that 48 per cent, almost half of the respondents do not perceive to be facing any personal problems because of the belief that women have better entrepreneurial skills over the male counterpart and are a better manager also. 
This confidence which women reflect during field surveys gives a sense of pride to the researcher by knowing the passion and self-belief female entrepreneurs possess.

\section{Social Problems}

In this part of the study researcher intends to unveil the problems lying in the very society where women entrepreneurs belong to. The common social problem as shown in Table 4.34 and Chart 4.29, faced by 77 per cent of women entrepreneurs is the dual role in home and business which sometimes may be troublesome but not to an extent that inhibit women to achieve their entrepreneurial aims because of families support. They find this problem generally because women often have responsibilities related to home and business which keeps them on their toes. It is followed by 43 per cent of respondents who believe that there exists lack of society's confidence on women's ability. This is still existing which bothers women to some extent but fails to stop women to pursue their dream. Other social problems include problems because of lack of appreciation in the family/society (39 per cent), lack of male dominance in the society (35 per cent) and problems arising as a result of lack of social contacts (34 per cent).

TABLE 4.34

Table to represent 'Social Problems' faced by women entrepreneurs

\begin{tabular}{|l|c|}
\hline \multicolumn{1}{|c|}{ Social Problems } & Frequency \\
\hline Dual role in home and business & 309 \\
\hline Lack of Society's confidence on women's ability & 171 \\
\hline Problems rising because of male dominance & 139 \\
\hline Problems rising because of lack of social contacts & 138 \\
\hline Problem because of lack of appreciation in the family/society & 157 \\
\hline
\end{tabular}

Primary Source 


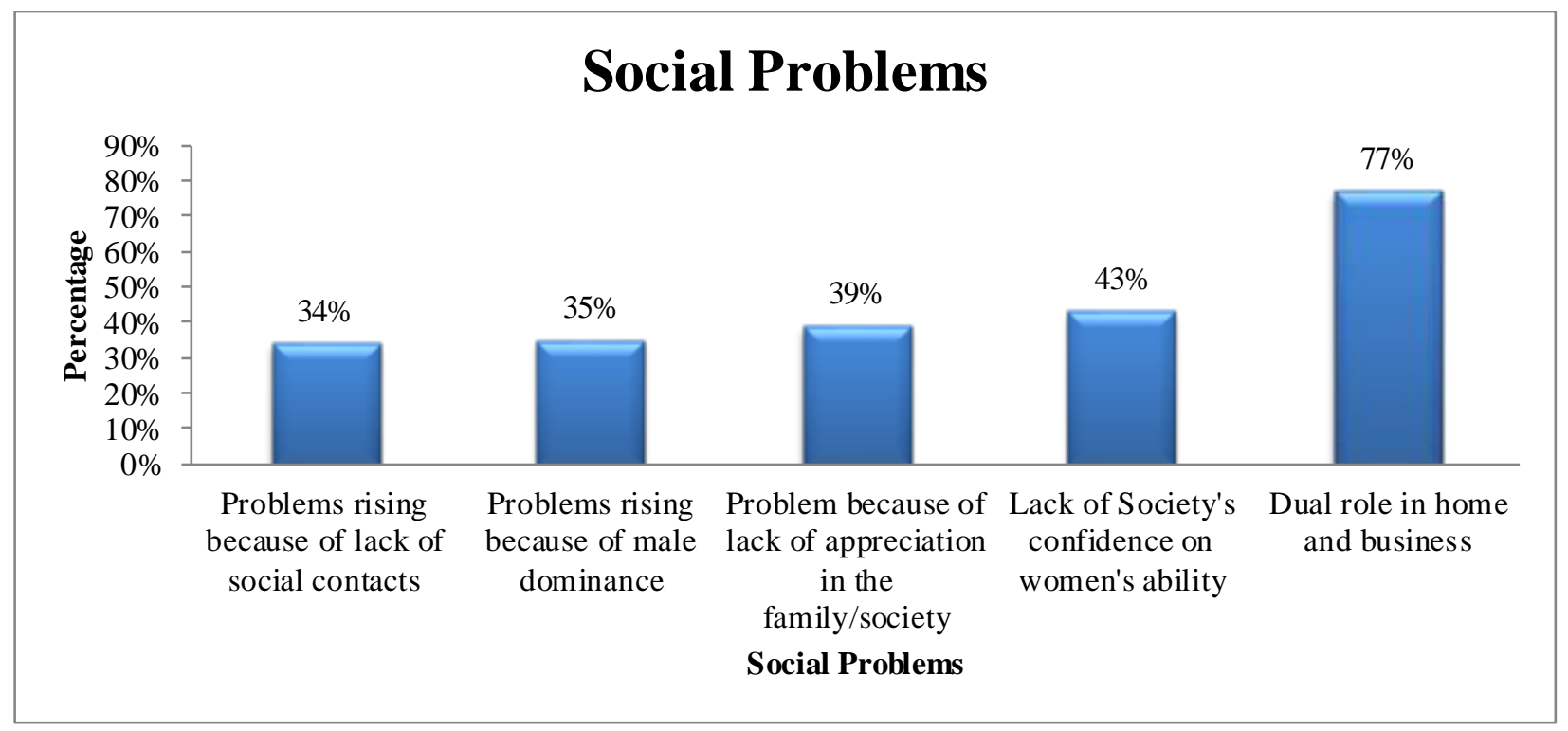

Primary Source

CHART 4.29

Bar Chart to represent 'Social Problems' faced by women entrepreneurs

The response of 43 per cent of respondents is worth giving a thought which mentions 'lack of society's confidence on women entrepreneurs'. Although less than half of the sample believes this, what has influenced them to think in this line? This is most of the times because of relatives, customers, male counterpart and financial institutions.

\section{Raw Material Problems}

Raw material becomes important input for successful functioning of business. In this part of data collection researcher intends to identify if there exist any problem for women entrepreneurs in accessing these resources. It is observed, as reflected in Tab le 4.35 and Chart 4.30 that for none of the raw material related points more that 40 per cent of women entrepreneurs have voted. It is because most of the women entrepreneurs belong to retail sector where raw material is not required. 
TABLE 4.35

Table to represent 'Problems related to raw material' for women entrepreneurs

\begin{tabular}{|l|c|}
\hline \multicolumn{1}{|c|}{ Problems related to raw material } & Frequency \\
\hline Lack of continuous supply of raw materials & 109 \\
\hline Variations in raw materials prices & 154 \\
\hline Delay in procurement of raw materials & 108 \\
\hline Poor Knowledge of Materials Management & 91 \\
\hline Time consuming procedures of getting raw materials & 110 \\
\hline Non availability of raw materials & 96 \\
\hline N.A & 83 \\
\hline
\end{tabular}

Primary Source

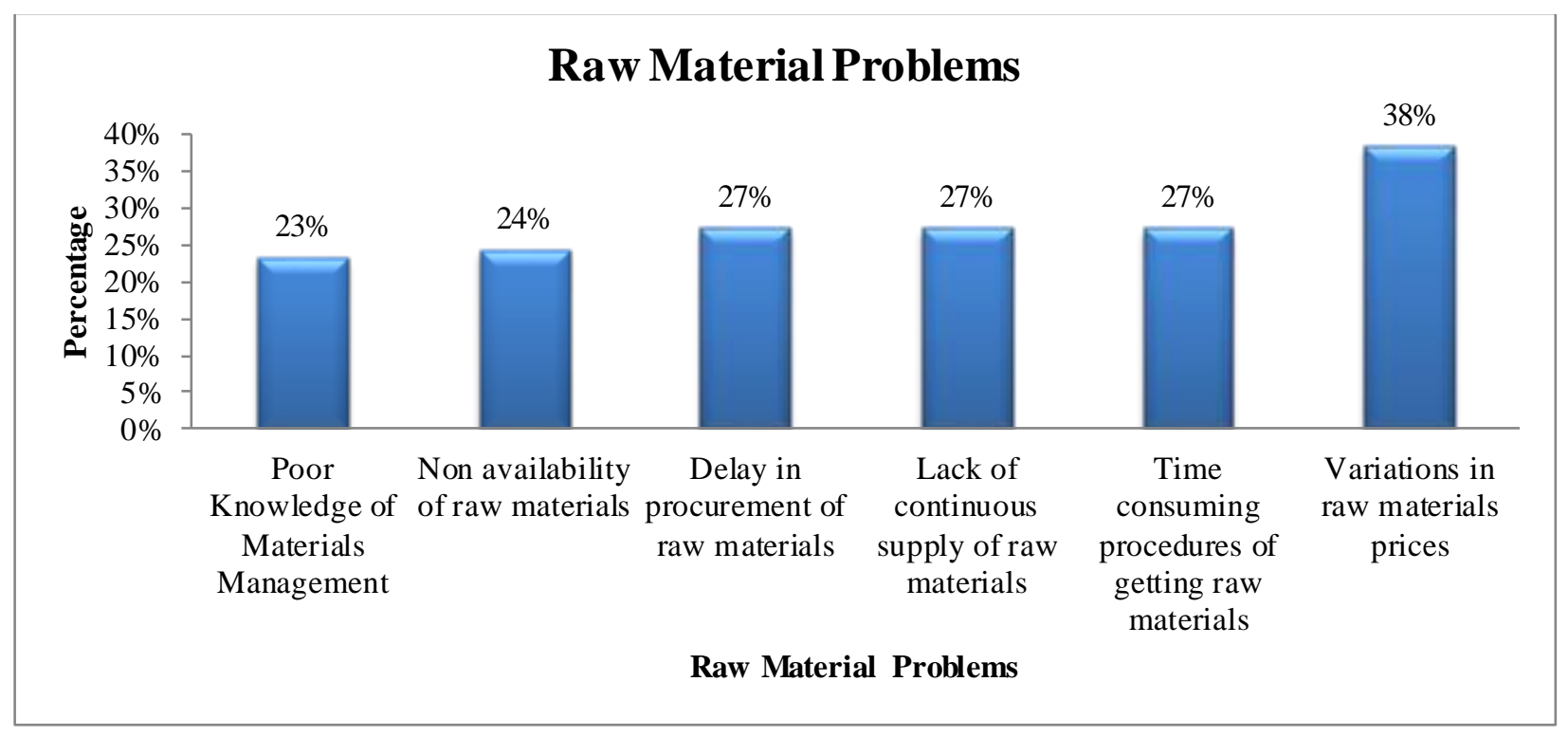

Primary Source

CHART 4.30

Bar Chart to represent 'Problems related to raw material' for women entrepreneurs

Those who face raw material related problems are because of variations in raw material problems (38 per cent); lack of continuous supply of raw materials, delay in procurement of raw material and time consuming procedure of getting raw materials (27 per cent each); nonavailability of raw materials (24 per cent); poor knowledge of materials management (23 per cent); and 21 per cent of respondents announced that this question is not applicable. 
It was observed during data collection that in general women entrepreneurs do not face problems in accessing raw material. The problems mentioned here are faced by male counterpart also therefore these are industry wide problems.

\section{E. Marketing Problems}

Marketing problems among women entrepreneurs as shown in Table 4.36 and Chart 4.31, depicts most important problem to be cut throat competition (67 per cent). According to the respondents this is a general problems faced by male counterpart also; inadequate advertising and publicity (45 per cent) because of ; lack of travelling capacity (44 per cent); poor knowledge of marketing management (41 per cent); lack of sufficient stock of products (35 per cent) and delayed collection of bills (26 per cent).

TABLE 4.36

Table to represent 'Marketing Problems' faced by women entrepreneurs

\begin{tabular}{|l|c|}
\hline \multicolumn{1}{|c|}{ Marketing Problems } & Frequency \\
\hline Cut throat competition & 270 \\
\hline Delayed collection of bills & 106 \\
\hline Inadequate advertising and publicity & 182 \\
\hline Lack of sufficient stock of products & 139 \\
\hline Poor Knowledge of Marketing Management & 164 \\
\hline Lack of travelling capacity & 178 \\
\hline
\end{tabular}

Primary Source 


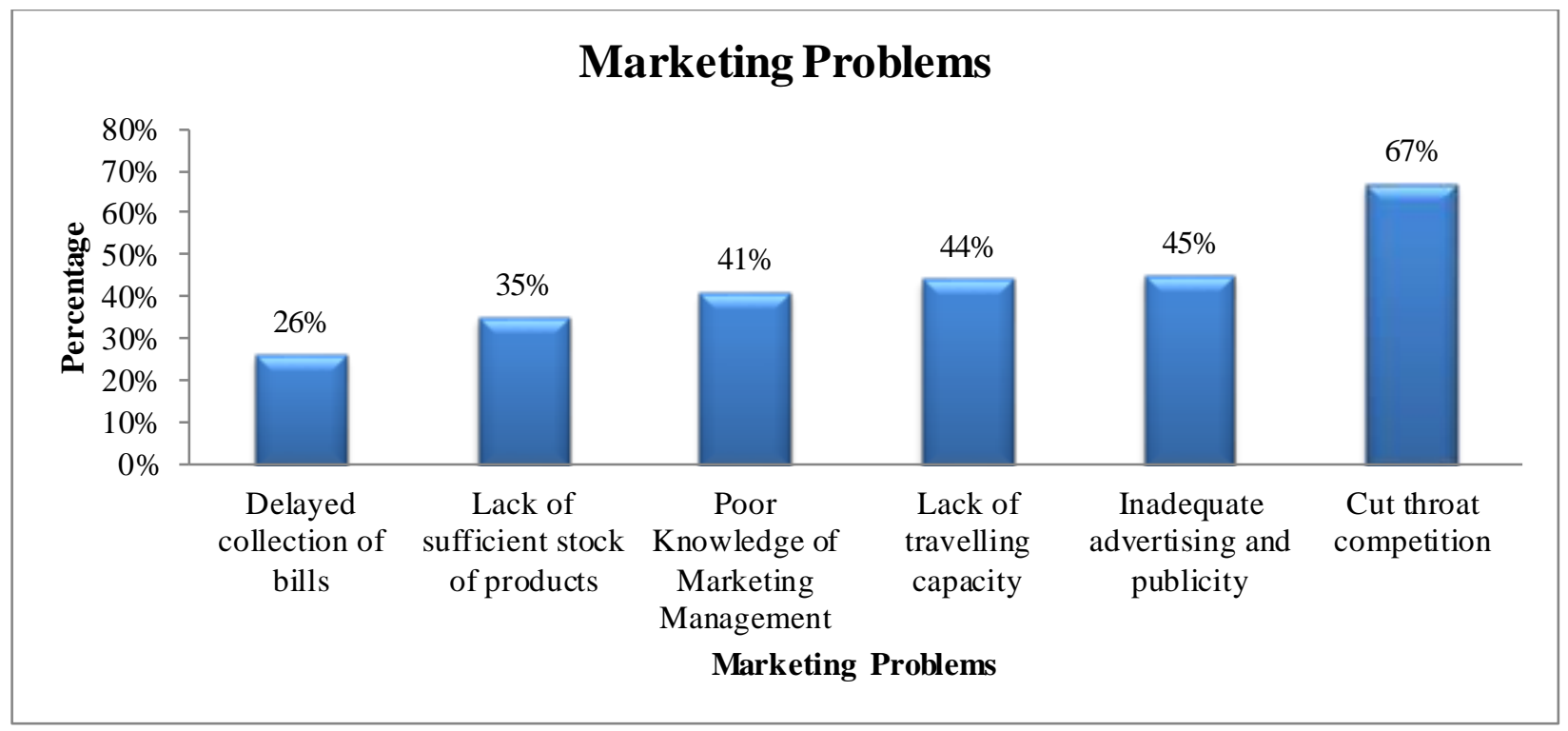

Primary Source

CHART 4.31

Bar Chart to represent 'Marketing Problems' faced by women entrepreneurs

According to respondents, cut throat competition which has been voted as major marketing problem. It also becomes problem for male counterparts. Therefore it can be considered as an industry wide problem. Besides this other problems have been voted by respondents but more than half of the respondents consider no major problems in marketing because for them, their dedicated effort and word of mouth has assures customers and profits ceaselessly.

They believe government has provided them marketing platforms in form of exhibitions and various 'artisan mela's' but many time they cannot travel across the country for the purpose of business rather chose to target localized customer base.

\section{F. Labor Related Problems}

Although it has been observed in the section 4.1.4.B 'Enabling Factors' that least of the respondents believe labor to be enabling factor (32 per cent), it is further asked whether respondents face any challenge coming from them to perform their day to day function. It is observed as represented in the Table 4.37 and Chart 4.32 that there exist two main challenges faced by 52 per cent of the participating respondents' i.e. non availability of skilled 
employees and employees leave job after getting experience. Other problems like noncooperative attitude of employees (24 per cent) and non-cooperative attitude of employees towards woman entrepreneurs as manager (21 per cent) exist but to a manageable extent. There are 22 per cent of respondents who declares that they run their business either alone, with family members or with a partner but do not have any employee.

TABLE 4.37

Table to represent 'Labor/Employee related problems' faced by women entrepreneurs

\begin{tabular}{|l|c|}
\hline Labor/Employee Related Problems & Frequency \\
\hline Non availability of Skilled employees & 207 \\
\hline Skilled employees leave their job after getting experience & 208 \\
\hline Non-cooperative attitude of employees & 95 \\
\hline Non-cooperative attitude towards Women Managers & 84 \\
\hline N.A & 88 \\
\hline
\end{tabular}

Primary Source

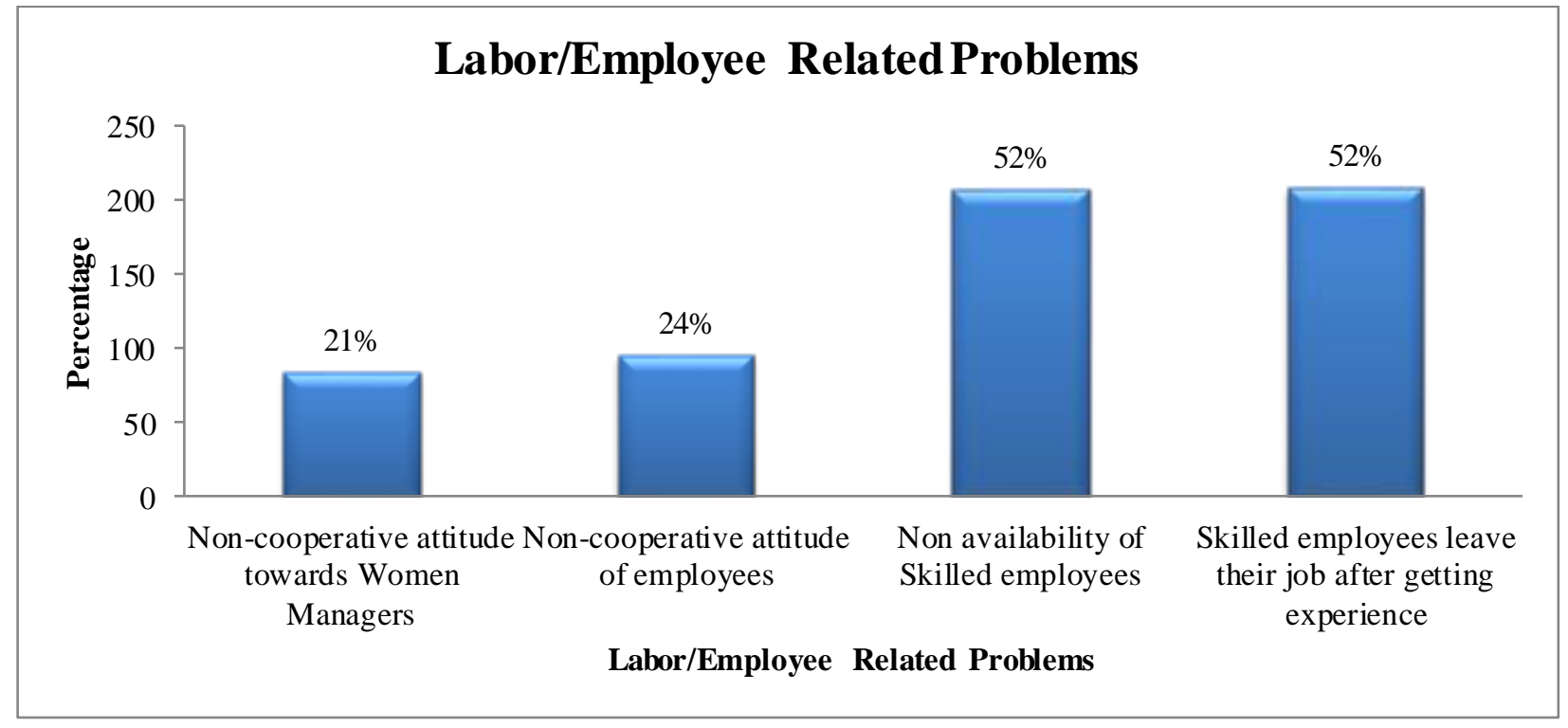

Primary Source

CHART 4.32

Bar Chart to represent 'Labor/Empl oyee related problems' faced by women entrepreneurs 
During the field survey it was persistent reply by the respondents that main problem is lacking the skilled employees and that they leave job after getting experience.

Also it has been constant response of almost half of the respondents (nearly 48 per cent) that they hardly find any major challenge coming from employees end. They find workers to be extremely cooperative and contributing to work.

\section{G. Managerial Problems}

While making an effort to dig into the managerial capabilities women entrepreneurs have, it surfaced that for most of the responses not more than 36 per cent of respondents have voted to call it a major challenge as represented in Table 4.38 and Chart 4.33. They consider themselves to be better managers than male counterpart. Only difference is they are losing because due to family responsibilities due to which they cannot exercise entrepreneurial ideas and skills to the fullest extent but only to a limited extent so that they can manage home and family simultaneously.

TABLE 4.38

Table to represent 'Problems related to Managerial Abilities' faced by women entrepreneurs

\begin{tabular}{|l|c|}
\hline Problem Related to Managenial Abilities & Frequency \\
\hline Lack of proper planning & 142 \\
\hline Lack of control & 112 \\
\hline Poor knowledge of business management & 144 \\
\hline Lack of decision making skill & 113 \\
\hline Lack of communication skill & 109 \\
\hline Lack of motivation to employees & 88 \\
\hline
\end{tabular}

Primary Source 


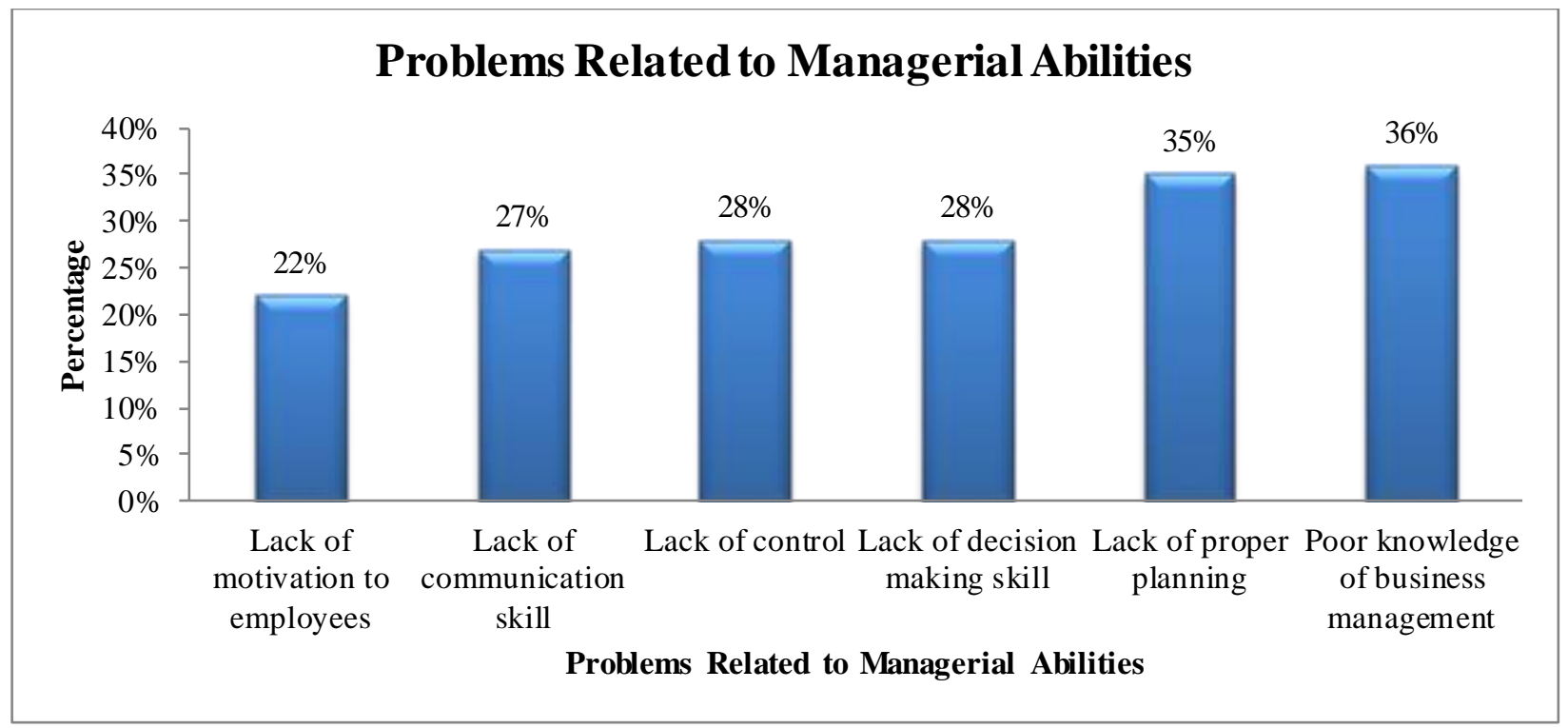

Primary Source

CHART 4.33

Bar Chart to represent 'Problems related to Managerial Abilities' faced by women entrepreneurs

If few of the problems occur they are poor knowledge of business management (36 per cent), lack of proper planning (35 per cent), lack of control and lack of decision making skills (28 per cent each), lack of communication skills (27 per cent) and lack of motivation to employees (22 per cent).

The statistics unveil the controlled nature of this problem and signals its solution lying in better 'Entrepreneurship Development Programmes (EDPs)'.

\section{H. Infrastructural Problems}

Infrastructural problems, as presented in Table 4.39 and Chart 4.34, indicate that the major problem for women entrepreneurs related to infrastructure is 'Inadequate space of work' (40 per cent). This according to the respondents is a universal problem irrespective of type of entrepreneur. Other problems are 'Non availability of land' (27 per cent), 'Inadequate transportation facility' (25 per cent), 'Inadequate power supply' (19 per cent) and 'Inadequate water supply' (14 per cent). 
One unique outcome of this study is the finding that very few respondents out of 25 per cent, who considers that there exists a problem of inadequate transport facility, believes that there exists an insecure transportation facility especially for women commuters. Women do not fear working late night in the market barring few and finds the environment in Gujarat 'women friendly' to work.

Few respondents showed their concern towards lack of transport facility for women commuters because due to safety issue women have to depend on the bus facilities which are available only until $7 \mathrm{pm}$ or $8 \mathrm{pm}$ due to which they have to shut their business down for the day. This can be called a women specific issue to be investigated.

TABLE 4.39

Table to represent 'Problems related to Infrastructural Difficulties' faced by women entrepreneurs

\begin{tabular}{|l|c|}
\hline Problems related to Infrastructural Difficulties & Frequency \\
\hline Inadequate space of work & 160 \\
\hline Inadequate power Supply & 75 \\
\hline Non availability of land / plot / shed & 110 \\
\hline Inadequate transportation facilities & 100 \\
\hline Inadequate water supply & 55 \\
\hline
\end{tabular}

Primary Source 


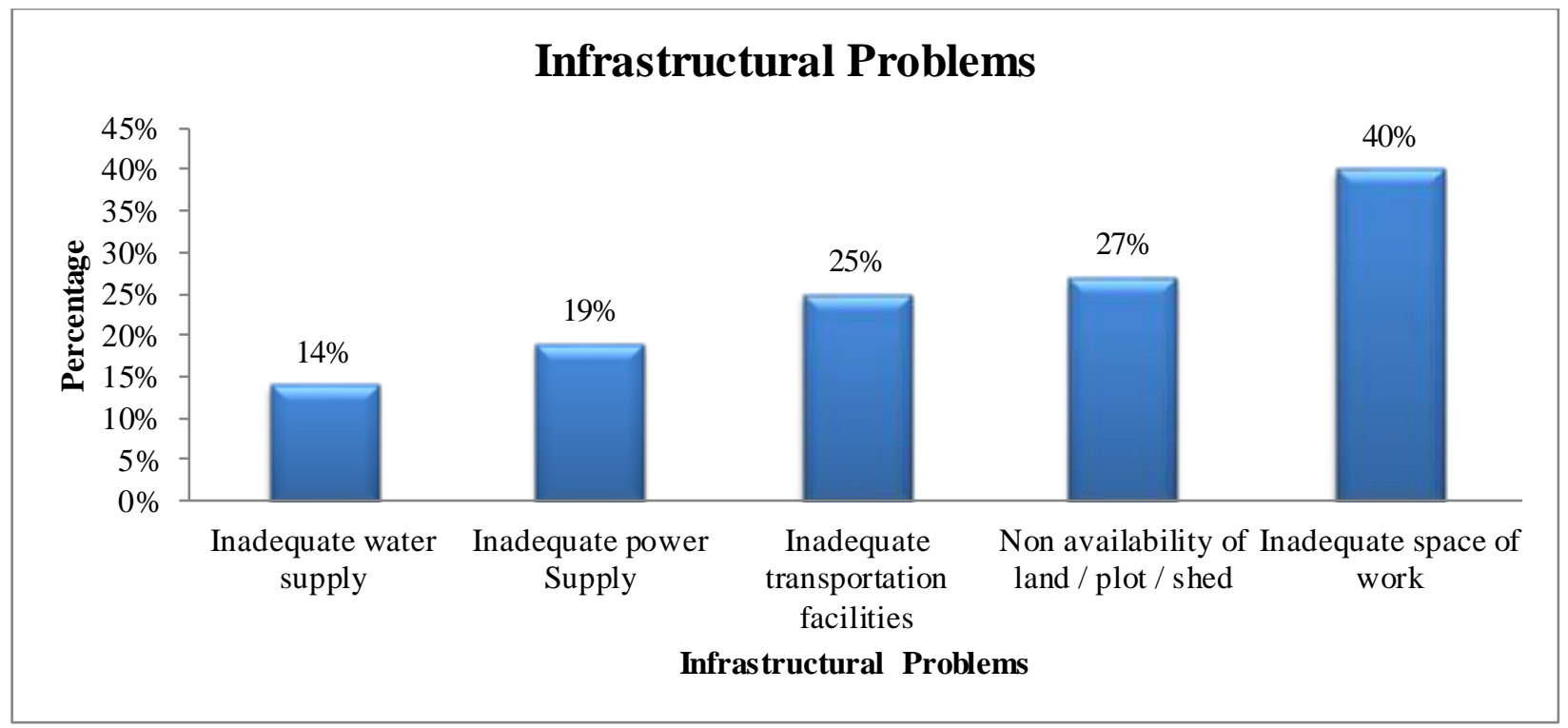

Primary Source

CHART 4.34

Bar Chart to represent 'Problems related to Infrastructural Difficulties' faced by women entrepreneurs

Other problems like inadequate of water facility, inadequate power supply are problems basically found only in rural areas. Further study can be conducted to highlight the comparative analysis of facilities provided to rural and urban entrepreneurs. As it is not under the scope of this study hence researcher is not in a position to draw further conclusion on it.

\section{Technological Problems}

For the technological problems faced by women entrepreneurs again it is evident by studying Table 4.40 and Chart 4.35 that for none of the problems pertaining to technological problem more than 46 per cent of total respondent has voted. It again highlights the confidence of women entrepreneurs on being technological savvy. It is apparently due to the fact that the nature of business they own does not need technological intensive operations. These are mainly micro or small scale businesses in which besides a mobile or/and a computer (only at few business establishments) can be seen falling under the criteria of technological instruments. Women entrepreneurs find themselves to be mobile and computer literate. 
Women entrepreneurs in many cases are observed not even using them specifically for business purposes yet successfully running their businesses since decades.

TABLE 4.40

Table to represent 'Problems related to Technological Difficulties' faced by women entrepreneurs

\begin{tabular}{|l|c|}
\hline Technology Problems & Frequency \\
\hline Lack of Technological Skills & 184 \\
\hline Inadequate technological support for machinery utilization & 108 \\
\hline Poor knowledge of modern technology & 166 \\
\hline High cost of technological acquisition & 176 \\
\hline Do not use technology & 123 \\
\hline
\end{tabular}

Primary Source

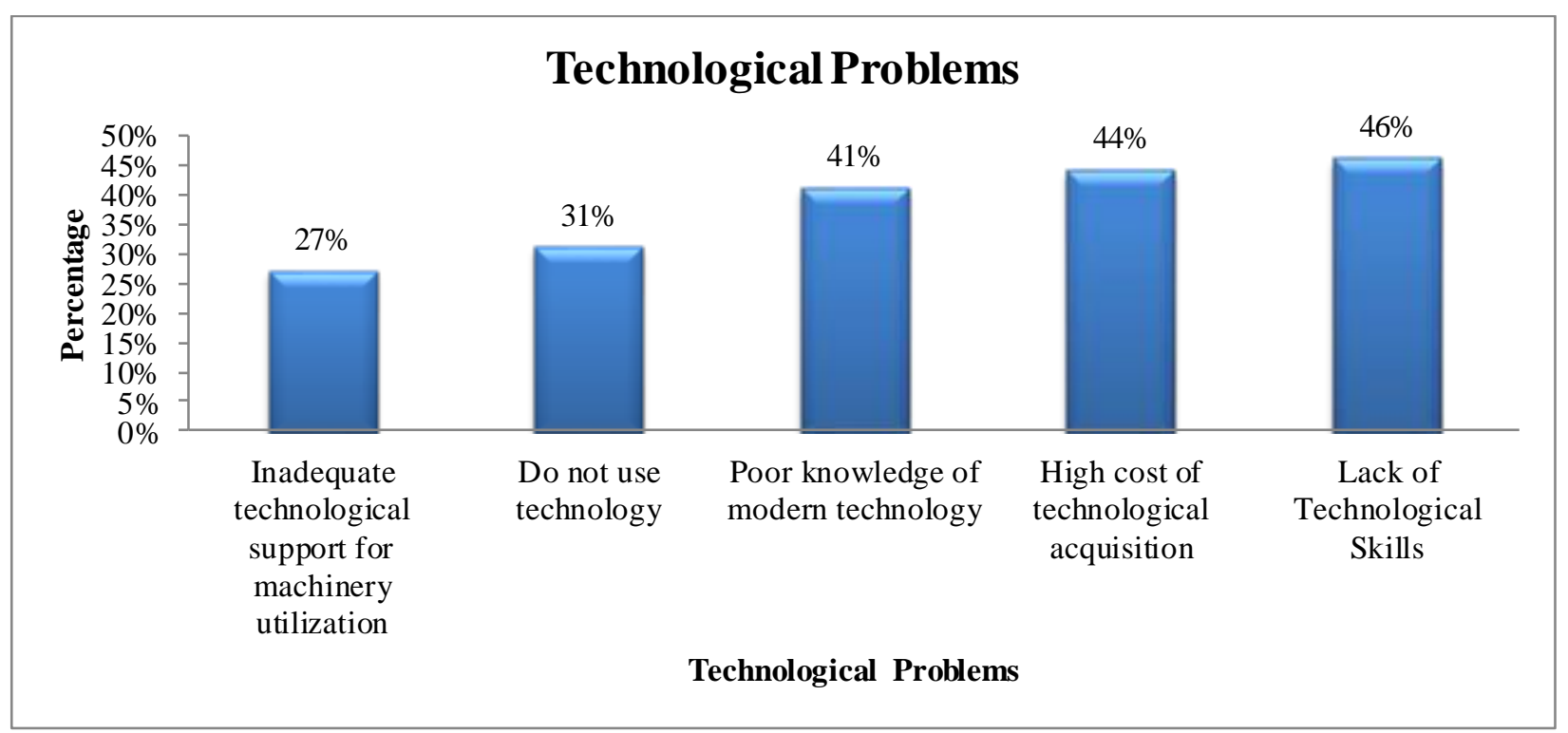

Primary Source

CHART 4.35

Bar Chart to represent 'Problems related to Technological Difficulties' faced by women entrepreneurs

It is also observed that women entrepreneurs who feel they lack technological skills did not consider it to be a major challenge because they can hire employees if they are in need of one but this does not hinder their motive to grow further hence cannot be counted as a problem. 
Besides these observations it is also observed that 46 per cent of respondents find the problem of lack of technological skills; 44 per cent of respondents observes high cost of technological problems to be a challenge; 41 per cent of respondents confesses to have poor knowledge of modern technology; 31 per cent respondents mentions they do not use technology for the functioning of their business and 27 per cent responds that there are inadequate technological support for machinery utilization.

It is important to note that for women entrepreneurs technological skills mean skills pertaining to operating applications in mobile, laptop, desktop and accessing internet. Researcher further added to their understanding that the knowledge pertaining to machinery they use for their business operations are also covered under technological skills. Hence with these background women entrepreneurs have responded to this part of the study.

According to the researcher these are also manageable problems and training by conducting Entrepreneurship Development Programmes can bring a solution to it.

\section{J. Government Support Problems}

This becomes an important section because we have been observing since decades that countless schemes have been framed and implemented by government to cater to this section of society and make them resourceful economic agents. Researcher is keen to know how it has influenced women entrepreneurs towards availing these benefits.

TABLE 4.41

Table to represent 'Problems related to Government Support' faced by women entrepreneurs

\begin{tabular}{|l|c|}
\hline \multicolumn{1}{|c|}{ Problems related to Govemment Support } & Frequency \\
\hline Corruption in Sanction of subsidy/incentive/loan & 129 \\
\hline Non-cooperative attitude of govt. employees & 108 \\
\hline Poor knowledge of government support schemes & 257 \\
\hline Discrimination with women entrepreneurs & 111 \\
\hline Lack of co-ordination among different government departments & 115 \\
\hline Never availed any government support & 166 \\
\hline
\end{tabular}

Primary Source 


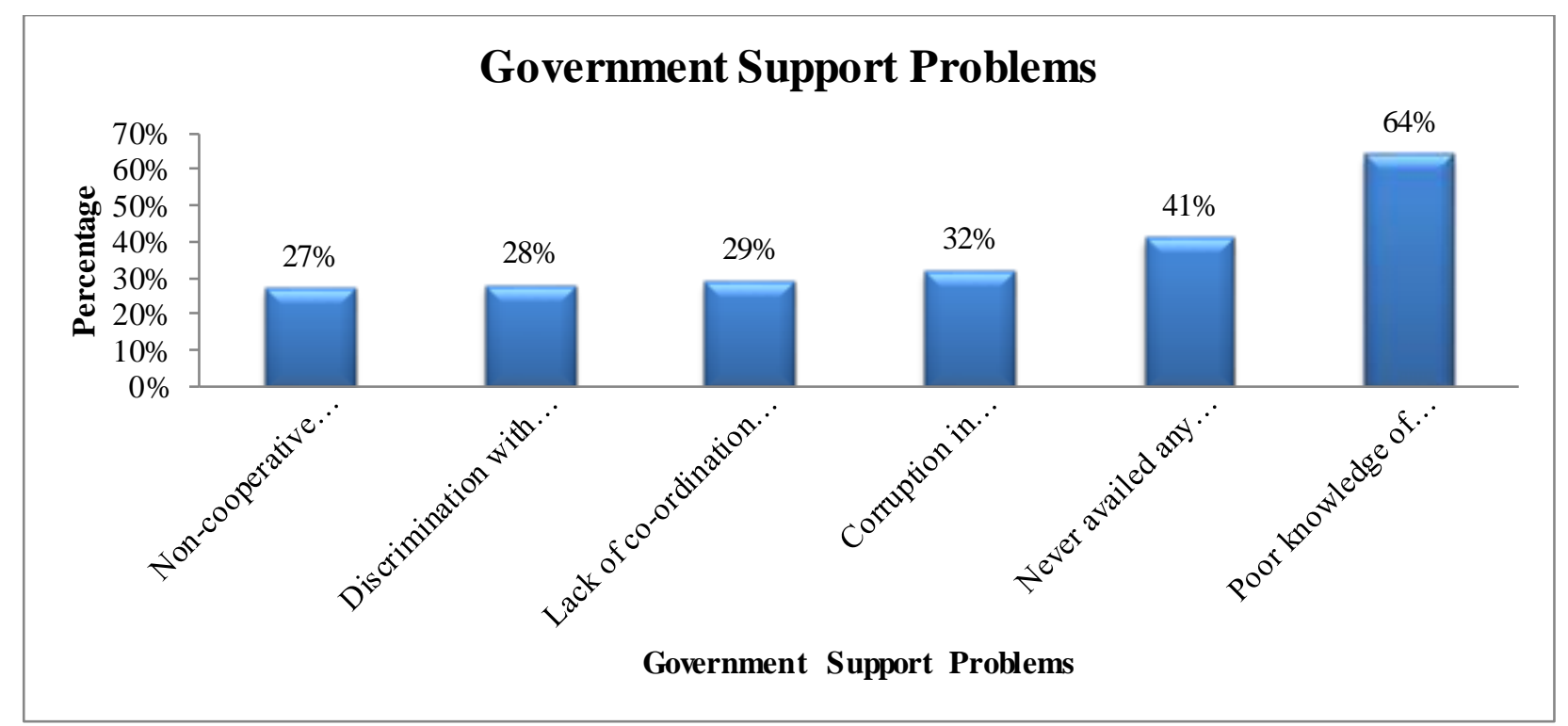

Primary Source

CHART 4.36

Bar Chart to represent 'Problems related to Government Support' faced by women entrepreneurs

The data in Table 4.41 and Chart 4.36 results that women have poor knowledge of government schemes (64 per cent), have never availed government support (41 per cent), observes a corruption in sanction of subsidy/incentive/loans (32 per cent), lack of coordination among different government departments (29 per cent), discrimination practiced against women entrepreneurs (28 per cent) and non cooperative attitude of government employees (27 per cent).

The result shows meager inclination of women entrepreneurs towards availing government support as 41 per cent women out rightly confesses to have never availed government support on any of the occasions whereas 64 per cent women entrepreneurs acknowledge their lack of knowledge on prevailing government schemes. Remaining problems which are observed are less pervasive in nature but needs special attention as these deter women entrepreneur especially at grass root level to seek government's aid for any purpose pertaining to business.

It is worth mentioning that women entrepreneurs at grass root le vel are especially observing the problem of corruption in sanctioning of subsidy/incentive/loans leading to leakage of funds instead of it being able to reach the right set of beneficiary in Gujarat. It calls for strict supervision by vigilance. 
Few women entrepreneurs also find lack of coordination among government departments and discrimination against women entrepreneurs as dissuading factor to be inclined towards availing government support.

\section{K. Consolidated overview of problems faced by women entrepreneurs}

A consolidated view towards the problems faced by women entrepreneurs as shown in Table 4.42 becomes important to track the most important problems this section of MSME faces which become a repelling force for women to start a business and eventually to sustain in business.

TABLE 4.42

Consolidated View at Problems Faced by Women Entrepreneurs in the State of Gujarat

\begin{tabular}{|c|c|c|}
\hline \multirow[b]{2}{*}{ Problems faced by women entrepreneurs } & \multicolumn{2}{|c|}{ Responses } \\
\hline & $\mathbf{N}$ & $\begin{array}{l}\text { Percent } \\
\text { of Cases }\end{array}$ \\
\hline Social Problems - Dual role in home and business & 309 & $77 \%$ \\
\hline Financial Problem - Limited Working Capital & 288 & $72 \%$ \\
\hline Marketing Problems - Cut throat competition & 270 & $67 \%$ \\
\hline $\begin{array}{l}\text { Government Support Problems - Poor knowledge of government } \\
\text { support schemes }\end{array}$ & 257 & $64 \%$ \\
\hline $\begin{array}{l}\text { Financial Problem - Ignorance about banking procedures and } \\
\text { formalities }\end{array}$ & 216 & $54 \%$ \\
\hline Financial Problem - Poor knowledge of financial management & 210 & $52 \%$ \\
\hline Personal Problems - Lack of leisure time & 210 & $52 \%$ \\
\hline $\begin{array}{l}\text { Labor/Employees related problems - Skilled employees leave their job } \\
\text { after getting experience }\end{array}$ & 208 & $52 \%$ \\
\hline $\begin{array}{l}\text { Labor/Employees related problems - Non availability of Skilled } \\
\text { employees }\end{array}$ & 207 & $52 \%$ \\
\hline Technological Problems - Lack of Technological Skills & 184 & $46 \%$ \\
\hline Marketing Problems - Inadequate advertising and publicity & 182 & $45 \%$ \\
\hline Marketing Problems - Lack of travelling capacity & 178 & $44 \%$ \\
\hline Technological Problems - High cost of technological acquisition & 176 & $44 \%$ \\
\hline Social Problems - Lack of Society's confidence on women's ability & 171 & $43 \%$ \\
\hline Technological Problems - Poor knowledge of modern technology & 166 & $41 \%$ \\
\hline $\begin{array}{l}\text { Government Support Problems - Never availed any Government } \\
\text { support }\end{array}$ & 166 & $41 \%$ \\
\hline
\end{tabular}




\begin{tabular}{|c|c|c|}
\hline Marketing Problems - Poor Knowledge of Marketing Mar & 164 & $41 \%$ \\
\hline Personal Problems - Avoidance of Economic Risk & 163 & $41 \%$ \\
\hline Financial Problem - Delayed payments of bills to creditors & 162 & $40 \%$ \\
\hline Personal Problems - Lack of risk bearing capacity & 160 & $40 \%$ \\
\hline Infrastructural Problems - Inadequate space of work & 160 & $40 \%$ \\
\hline $\begin{array}{l}\text { Social Problems - Problem because of lack of appreciation in the } \\
\text { family/society }\end{array}$ & 157 & $39 \%$ \\
\hline Raw Material Problem - Variations in raw materials prices & 154 & $38 \%$ \\
\hline Financial Problem - Lack of Collateral Security & 144 & $36 \%$ \\
\hline Managerial Problems - Poor knowledge of business management & 144 & $36 \%$ \\
\hline Managerial Problems - Lack of proper planning & 142 & $35 \%$ \\
\hline Social Problems - Problems rising because of male dominance & 139 & $35 \%$ \\
\hline Marketing Problems - Lack of sufficient stock of products & 139 & $35 \%$ \\
\hline Social Problems - Problems rising because of lack of social contacts & 138 & $34 \%$ \\
\hline $\begin{array}{l}\text { Government Support Problems - Corruption in Sanction of } \\
\text { subsidy/incentive/loan }\end{array}$ & 129 & $32 \%$ \\
\hline Personal Problems - Lack of initiative & 128 & $32 \%$ \\
\hline Technological Problems - Don't use technology & 123 & $31 \%$ \\
\hline $\begin{array}{l}\text { Government Support Problems - Lack of co-ordination among } \\
\text { different government departments }\end{array}$ & 115 & $29 \%$ \\
\hline Personal Problems - Lack of Self Confidence & 113 & $28 \%$ \\
\hline Managerial Problems - Lack of decision making skill & 113 & $28 \%$ \\
\hline Managerial Problems - Lack of control & 112 & $28 \%$ \\
\hline $\begin{array}{l}\text { Government Support Problems - Discrimination with women } \\
\text { entrepreneurs }\end{array}$ & 111 & $28 \%$ \\
\hline $\begin{array}{l}\text { Raw Material Problem - Time consuming procedures of getting raw } \\
\text { materials }\end{array}$ & 110 & $27 \%$ \\
\hline Infrastructural Problems - Non availability of land / plot / shed & 110 & $27 \%$ \\
\hline Raw Material Problem - Lack of continuous supply of raw materials & 109 & $27 \%$ \\
\hline Managerial Problems - Lack of communication skill & 109 & $27 \%$ \\
\hline Raw Material Problem - Delay in procurement of raw materials & 108 & $27 \%$ \\
\hline $\begin{array}{l}\text { Technological Problems - Inadequate technological support for } \\
\text { machinery utilization }\end{array}$ & 108 & $27 \%$ \\
\hline $\begin{array}{l}\text { Government Support Problems - Non-cooperative attitude of govt. } \\
\text { employees }\end{array}$ & 108 & $27 \%$ \\
\hline Financial Problem - Negative attitude of banks towards women & 106 & $26 \%$ \\
\hline Marketing Problems - Delayed collection of bills & 106 & $26 \%$ \\
\hline Personal Problems - Absence of need of achievement & 101 & $25 \%$ \\
\hline Infrastructural Problems - Inadequate transportation facilities & 100 & $25 \%$ \\
\hline Raw Material Problem - Non availability of raw materials & 96 & $24 \%$ \\
\hline $\begin{array}{l}\text { Labour/Employees related problems - Non-cooperative attitude of } \\
\text { employees }\end{array}$ & 95 & $24 \%$ \\
\hline Raw Material Problem - Poor Knowledge of Materials Management & 91 & $23 \%$ \\
\hline Labour/Employees related problems - N.A & 88 & $22 \%$ \\
\hline Managerial Problems - Lack of motivation to employees & 88 & $22 \%$ \\
\hline $\begin{array}{l}\text { Labour/Employees related problems - Non-cooperative attitude } \\
\text { towards Women Managers }\end{array}$ & 84 & $21 \%$ \\
\hline
\end{tabular}




\begin{tabular}{|l|r|c|} 
Raw Material Problem - N.A & 83 & $21 \%$ \\
\hline Infrastructural Problems - Inadequate power Supply & 75 & $19 \%$ \\
\hline Infrastructural Problems - Inadequate water supply & 55 & $14 \%$ \\
\hline
\end{tabular}

Primary Source

According to this consolidated view top ten prevailing problems that women entrepreneurs face are Social Problems - Dual role in home and business (77 per cent), Limited Working Capital (71 per cent), Cut throat competition (67 per cent), Poor knowledge of government support schemes ( 64 per cent), Ignorance about banking procedures and formalities (54 per cent), Poor knowledge of financial management (52 per cent), Lack of leisure time (52 per cent), Skilled employees leave their job after getting experience (52 per cent), Non availability of Skilled employees (52 per cent) and Lack of Technological Skills (46 per cent).

Out of these important problems few are general problems (lack of working capital and cut throat competition) which are faced by all (irrespective of gender) those who are involved in business as an occupation, but there are few imperative women specific problems which are faced by women more over men counterpart. These are dual role in home and business, poor knowledge of government support schemes, ignorance about banking procedures and formalities, poor knowledge of financial management, lack of leisure time and lack of technological skills. The next section K.1, K.2, K.3, K.4 and K.5 discuss the impact of various independent variables on: -

- Dual role in home and business

- Poor knowledge of government support schemes

- Ignorance about banking procedures and formalities

- Poor knowledge of financial management

- Lack of technological skills

Lack of leisure time although observed by majority of women entrepreneurs but do not form a major limiting factor which inhibit them to pursue their entrepreneurial dreams rather motivates them to perform with enhanced zeal and perseverance. Therefore the researcher is focusing on those problems which become an inhibiting or limiting factor for women entrepreneurs to run and survive in their business venture. 


\section{K.1. Problem of Dual role for women entrepreneurs}

H5 - Dual role problem for women entrepreneurs is independent of their age as an effectual variable.

H5 - Dual role problem for women entrepre neurs is not independent of their age as an effectual variable.

A Chi-square test of independence is calculated comparing the frequency of respondents suffering from problem of dual role in home and business and frequency of their age. A significant interaction is found $\left(\chi^{2}=11.52, \mathrm{p}<0.05\right)$. Table. 4.43 show that as the age increases this problem increases till the age of 45 . 36 years of age to 45 years is the age bracket where almost 85 per cent of women entrepreneurs are observed facing this problem due to increased family and business responsibilities. The various family responsibilities during this age is related to managing home and children as they (children) are in critical stage on education front. They are mostly appearing for their matriculation or intermediary exams and hence seek more attention at home from their parents. After this stage from the age group of 46 years and beyond when children are out of their education, they (children) also become a helping hand in business of their mother and hence contribute in managing the business which lessens the problem of dual role in family and business for women entrepreneurs. Hence in this case null hypothesis is rejected.

TABLE 4.43

Table to represent the relation between dual role in home and business as a problem and age of respondent as an effectual variable.

\begin{tabular}{|c|c|c|c|c|}
\hline & \multicolumn{2}{|c|}{$\begin{array}{l}\text { Social Problems - Dual role in home and } \\
\text { business }\end{array}$} & \multirow[b]{2}{*}{ Total } \\
\hline & & Yes & No & \\
\hline \multirow{5}{*}{$\begin{array}{l}\text { Age of the } \\
\text { respondent }\end{array}$} & Below 25 & 18 & 7 & 25 \\
\hline & $26-35$ & 103 & 33 & 136 \\
\hline & $36-45$ & 120 & 20 & 140 \\
\hline & $46-55$ & 47 & 24 & 71 \\
\hline & Above 55 & 21 & 8 & 29 \\
\hline \multicolumn{2}{|l|}{ Total } & 309 & 92 & 401 \\
\hline
\end{tabular}




\section{K.2. Poor Knowledge of Government Schemes among Women Entrepreneurs in the State of Gujarat}

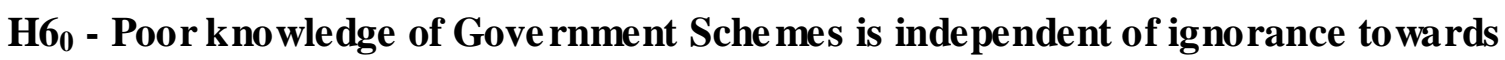
banking procedures and formalities among women entrepreneurs in the state.

H6 - Poor knowledge of Government Schemes is not independent of ignorance towards banking procedures and formalities among women entrepreneurs in the state.

A Chi-square test of independence is calculated comparing the frequency of respondents suffering from problem of poor knowledge of Government Schemes and problem of ignorance towards banking procedures and formalities. A significant interaction is found $\left(\chi^{2}=\right.$ 3.99, $\mathrm{p}<0.05$ ). Therefore, poor knowledge of government schemes is not independent of ignorance towards banking procedures and formalities. Table. 4.44 represents that those women entrepreneurs who agree to be ignorant about banking procedures and formalities also tend to be agreeing that they possess a poor knowledge of government schemes. This reflects that personal characteristics play an instrumental role when it running and making effort to sustain in business. This is found occurring due to the general notion that government bodies and banking institutions do not prove to be extremely effective in extending helping hand to women entrepreneurs and entangles them more into documentary procedures. This does not help in growing business and hence women look for alternatives in case of assistance required.

Due to the existence of this relationship between the two variables null hypothesis is rejected. 
TABLE 4.44

Table to represent the relation between Poor Knowledge of Government Support Schemes and Ignorance about Banking Procedures and Formalities among Women Entrepreneurs in the State

\begin{tabular}{|c|c|c|c|c|}
\hline & \multicolumn{2}{|c|}{$\begin{array}{c}\text { Govemment Support Problems - } \\
\text { Poor knowledge of government } \\
\text { support schemes }\end{array}$} & \multirow[b]{2}{*}{ Total } \\
\hline & & Yes & No & \\
\hline \multirow{2}{*}{$\begin{array}{l}\text { Financial Problem - Ignorance } \\
\text { about banking procedures and } \\
\text { formalities }\end{array}$} & Yes & 148 & 68 & 216 \\
\hline & No & 109 & 76 & 185 \\
\hline \multicolumn{2}{|l|}{ Total } & 257 & 144 & 401 \\
\hline
\end{tabular}

Primary Source

\section{K.3. Ignorance about Banking Procedures and Formalities -}

H7 $7_{0}$ - Ignorance towards banking procedures and formalities is independent of age of women entrepreneurs as an effectual variable.

H7 - Ignorance towards banking procedures and formalities is not independent of age of women entrepreneurs as an effectual variable.

A Chi-square test of independence is calculated comparing the frequency of respondents suffering from problem of ignorance towards banking procedures and formalities and age of the respondents as effectual variable. A significant interaction is found $\left(\chi^{2}=16.024, \mathrm{p}<\right.$ 0.05). This depicts that feature of ignorance about banking procedures and a formality among the women entrepreneurs is not independent of age as an effectual variable.

Table. 4.45 shows that ignorance about banking procedures and formalities is found more in women aged from 36-45 years of age (67 per cent) against other counterparts. It is due to the fact that during this period women remain more dependent on their husbands for financial matters and pay less attention on and eventually generates ignorance about banking procedures and formalities.

Hence in this case null hypothesis is rejected. 
Table to represent the relationship between problem of ignorance about banking procedures and formalities and Age as an effectual Variable among Women Entrepreneurs in the State

\begin{tabular}{|c|c|c|c|c|c|}
\hline & \multicolumn{2}{|c|}{$\begin{array}{l}\text { Financial Problem - } \\
\text { Ignorance about } \\
\text { banking procedures } \\
\text { and formalities }\end{array}$} & \multirow{3}{*}{$\begin{array}{r}\text { Total } \\
25 \\
\end{array}$} \\
\hline & & & \multirow{2}{*}{$\begin{array}{l}\text { Yes } \\
13\end{array}$} & \multirow{2}{*}{$\begin{array}{l}\text { No } \\
12 \\
\end{array}$} & \\
\hline \multirow{10}{*}{$\begin{array}{l}\text { Age of the } \\
\text { respondent }\end{array}$} & \multirow{2}{*}{ Below 25} & Count & & & \\
\hline & & $\%$ within Age of the respondent & $52 \%$ & $48 \%$ & 1 \\
\hline & \multirow{2}{*}{ 25-35 } & Count & 61 & 75 & 136 \\
\hline & & \% within Age of the respondent & $44.80 \%$ & $55.10 \%$ & $100 \%$ \\
\hline & \multirow{2}{*}{$36-45$} & Count & 94 & 46 & 140 \\
\hline & & $\%$ within Age of the respondent & $67.14 \%$ & $32.85 \%$ & $100 \%$ \\
\hline & \multirow{2}{*}{ 46-55 } & Count & 33 & 38 & 71 \\
\hline & & $\%$ within Age of the respondent & $46.47 \%$ & $53.52 \%$ & $100 \%$ \\
\hline & \multirow{2}{*}{ Above 55} & Count & 15 & 14 & 29 \\
\hline & & \% within Age of the respondent & $51.72 \%$ & $48.27 \%$ & $100 \%$ \\
\hline \multirow{2}{*}{\multicolumn{2}{|c|}{ Total }} & Count & 216 & 185 & 401 \\
\hline & & \% within Age of the respondent & $53.86 \%$ & $46.13 \%$ & $100 \%$ \\
\hline
\end{tabular}

Primary Source

\section{K.4. Poor Knowledge of Financial Management -}

H8 - Poor knowledge of financial management is independent of education of women entrepreneurs as an effectual variable.

H8 - Poor knowledge of financial manage ment is not independent of education of women entrepreneurs as an effectual variable.

A Chi-square test of independence is calculated comparing the frequency of respondents suffering from problem of poor knowledge of financial management and education level of the respondents as effectual variable. A significant interaction is found $\left(\chi^{2}=17.886, \mathrm{p}<\right.$ 0.05). This reflects that these two variables are not independent of each other rather dependent. 
Table to represent the relationship between Poor knowledge of Financial Management and Education level of the Women Entrepreneurs in the State

\begin{tabular}{|c|c|c|c|c|c|}
\hline & \multicolumn{2}{|c|}{$\begin{array}{l}\text { Financial Problem - Poor } \\
\text { knowledge of financial } \\
\text { management }\end{array}$} & \multirow[b]{2}{*}{ Total } \\
\hline & & & Yes & No & \\
\hline \multirow{12}{*}{$\begin{array}{c}\text { Education of } \\
\text { the } \\
\text { Respondent }\end{array}$} & & Count & 9 & 3 & 12 \\
\hline & Illiterate & $\begin{array}{l}\text { \% within } \\
\text { Education of the } \\
\text { Respondent }\end{array}$ & $75 \%$ & $25 \%$ & $100 \%$ \\
\hline & \multirow[b]{2}{*}{$\begin{array}{l}\text { Below } \\
\text { Matricula } \\
\text { tion } \\
\end{array}$} & Count & 27 & 13 & 40 \\
\hline & & $\begin{array}{l}\text { \% within } \\
\text { Education of the } \\
\text { Respondent }\end{array}$ & $67.50 \%$ & $3.25 \%$ & $100 \%$ \\
\hline & \multirow[b]{2}{*}{$\begin{array}{l}\text { Matricula } \\
\text { tion }\end{array}$} & Count & 26 & 8 & 34 \\
\hline & & $\begin{array}{l}\text { \% within } \\
\text { Education of the } \\
\text { Respondent }\end{array}$ & $76.47 \%$ & $23.52 \%$ & $100 \%$ \\
\hline & \multirow[b]{2}{*}{$\begin{array}{l}\text { Intermedi } \\
\text { ate }\end{array}$} & Count & 18 & 22 & 40 \\
\hline & & $\begin{array}{l}\text { \% within } \\
\text { Education of the } \\
\text { Respondent }\end{array}$ & $45 \%$ & $55 \%$ & $100 \%$ \\
\hline & \multirow[b]{4}{*}{$\begin{array}{l}\text { Postgradu } \\
\text { ate }\end{array}$} & Count & 81 & 93 & 174 \\
\hline & & $\begin{array}{l}\text { \% within } \\
\text { Education of the } \\
\text { Respondent }\end{array}$ & $46.55 \%$ & $53.44 \%$ & $100 \%$ \\
\hline & & Count & 49 & 52 & 101 \\
\hline & & $\begin{array}{l}\text { \% within } \\
\text { Education of the } \\
\text { Respondent }\end{array}$ & $48.51 \%$ & $51.48 \%$ & $100 \%$ \\
\hline \multirow{2}{*}{\multicolumn{2}{|c|}{ Total }} & Count & 210 & 191 & 401 \\
\hline & & $\begin{array}{l}\text { \% within } \\
\text { Education of the } \\
\text { Respondent }\end{array}$ & $52.36 \%$ & $47.63 \%$ & $100 \%$ \\
\hline
\end{tabular}

Primary Source

It is clearly visible in Table. 4.46 that the problem of poor knowledge of financial management is found prevailing in the women entrepreneurs with lesser education level like illiterate (75 per cent), below matriculation (67.50 per cent) and matriculation (76 per cent). Women entrepreneurs with higher education level are found having lesser problems related to poor knowledge of financial management as visible in table. It is due to the improved 
exposure education provides to an individual, that women are able to use learning of these exposures to manage business finances.

Hence null hypothesis is rejected.

\section{K.5. Lack of Technological Skills -}

H9, - Lack of technological skills as a problem for women entrepreneur is independent of lack of need of achievement in women entrepreneurs as an effectual variable.

H9 - Lack of technological skills as a problem for women entrepreneur is not independent of lack of need of achievement in women entrepreneurs as an effectual variable.

A Chi-square test of independence is calculated comparing the frequency of respondents suffering from problem of 'Lack of technological skills' and problem of 'Absence of need of achievement' among the respondents as effectual variable. A significant interaction is found $\left(\chi^{2}=6.052, \mathrm{p}<0.05\right)$. This reflects that these two variables are not independent of each other rather dependent.

As evident in Table 4.47, a total of 101 women entrepreneurs believe that they have a personal problem of absence of need of achievement. Majority of these 101 women entrepreneurs i.e. 57 (i.e. 56.4 per cent) women entrepreneurs also agree that they lack technological skills. On the other hand a total of 300 women entrepreneurs have favored that they do not have the problem of absence of need of achievement. Majority of these 300 women entrepreneurs i.e. 173 (57.6 per cent) of women entrepreneurs have agreed that they do not face the problem of lack of technological skills.

This is due to the fact that women entrepreneurs who are satisfied with the current status of their business are not inclined to introduce any change to their status quo. Only if they are not, they work towards learning new skills or introduce upgraded technologies for enhanced performance of their business. 
TABLE 4.47

Table to represent the relationship between Lack of Technological Skills as a problem and Absence of Need of Achievement among Women Entrepreneurs as an effectual variable in the State

\begin{tabular}{|c|c|r|r|r|}
\hline \multirow{2}{*}{\multicolumn{2}{|c|}{}} & \multicolumn{2}{|c|}{$\begin{array}{c}\text { Technological Problems - Lack of } \\
\text { Technological Skills }\end{array}$} \\
\cline { 3 - 5 } & \multicolumn{2}{|c|}{ Yes } & \multicolumn{1}{|c|}{ No } & Total \\
\hline \multirow{2}{*}{$\begin{array}{c}\text { Personal Problems - Absence of } \\
\text { need of achievement }\end{array}$} & Yes & 57 & 44 & 101 \\
\cline { 3 - 6 } & No & 127 & 173 & 300 \\
\hline Total & & 184 & 217 & 401 \\
\hline
\end{tabular}

Primary Source

\subsection{Prospects for Women Entrepreneurs}

In this section of study researcher is attempting to analyze and present women entrepreneurs viewpoint about prospective factors

\section{A. Factors contributing to prospects of women entrepreneurs in the state of Gujarat}

Data on prospective factors enriches our awareness on the factors which encourage women entrepreneurs to prosper in their ambition. As per Table 4.48 and Chart 4.37 according to 80 per cent of respondents' most promising factors has been increasing awareness of women towards economic independence and increasing number of successful women (irrespective of their occupation) in society. 79 per cent women entrepreneurs proposes increasing spread of education among women as a vital prospective factor as enables women comprehend their choice of occupation and motivates women to pursue them. 76 per cent of women entrepreneurs believe that increasing social recognition to women becomes a fulcrum to bring women ahead from each family. According to 73 per cent of respondents increasing equality status of women in the society has played pivotal role for many women to come forward and exploit opportunities in surrounding. Increasing automation of household activity like increasing usage of microwave/washing machine/dishwasher and other household activities makes life easier to manage and maintain a balance between work and family for 72 per cent of respondents. For 62 per cent of respondents peer effect is also a eligible factor that 
becomes a push factor for women to match with how their peer are growing in their respective occupations.

TABLE 4.48

Table to represent 'Prospective factors' that contribute to women entrepreneurship in Gujarat

\begin{tabular}{|l|c|}
\hline \multicolumn{1}{|c|}{ Factors contributing to prospects } & Frequency \\
\hline Increasing spread of education among women & 318 \\
\hline Increasing social recognition to women & 307 \\
\hline Increasing awareness of women about economic independence & 322 \\
\hline Peer effect & 259 \\
\hline Increasing number of successful women in society & 322 \\
\hline $\begin{array}{l}\text { Increasing automation of household work (Increasing usage of microwave, } \\
\text { washing machines, dish washer kind of electronic equipments for household } \\
\text { work) }\end{array}$ & 291 \\
\hline Increasing equality status of women & 294 \\
\hline
\end{tabular}

Primary Source

Many researchers have time and again pointed out at the lack of role model for women entrepreneurs to be a deterring factor to pursue entrepreneurship as an occupation. This study also confirms the importance of successful women in society or role model as a prospective factor. Hence indicates that in Gujarat there are number of women entrepreneur role model who motivates women to pursue and relish their entrepreneurial aspirations. 


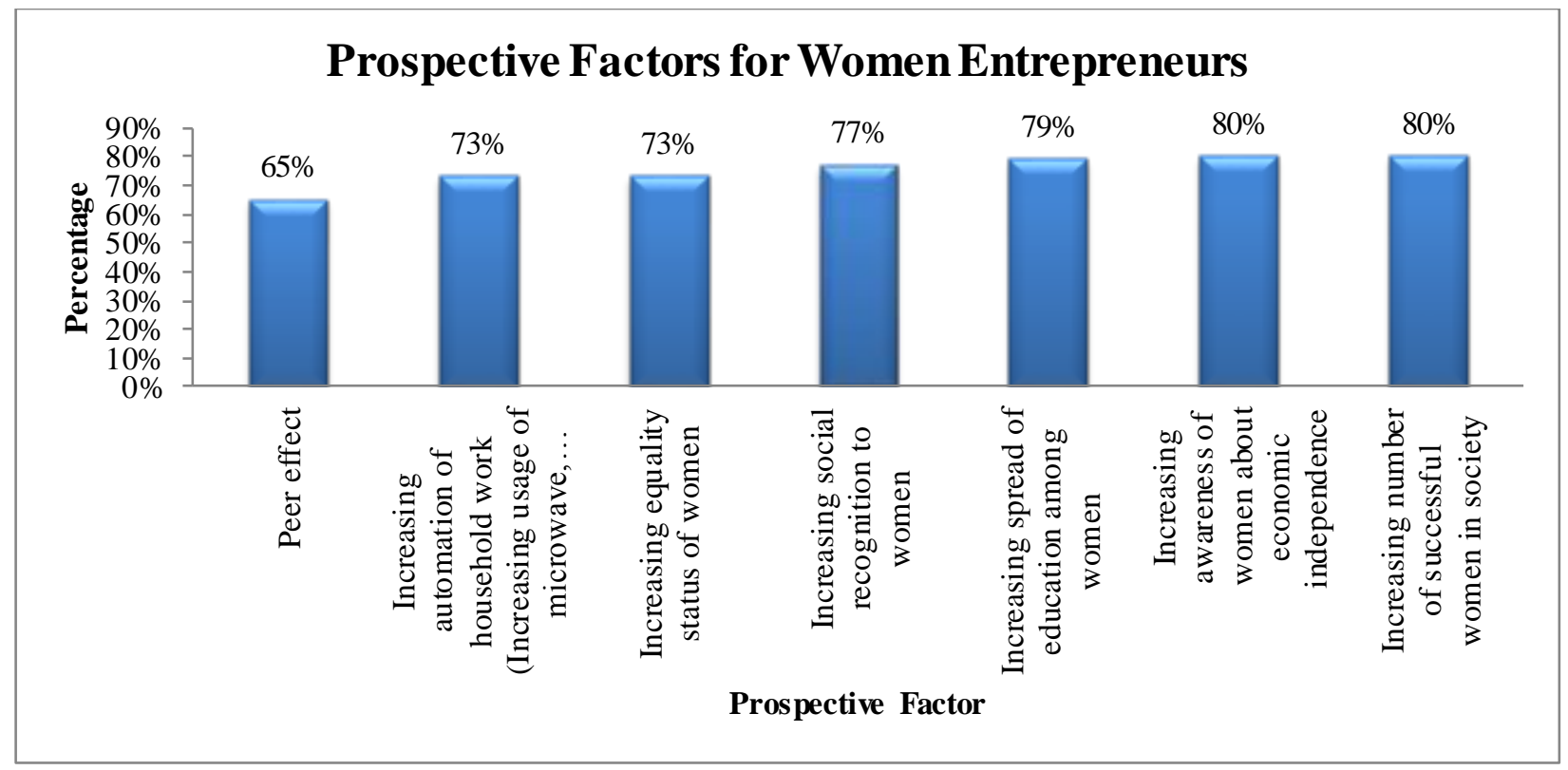

Primary Source

CHART 4.37

Bar Chart to represent 'Prospective factors' that contribute to women entrepreneurship in Gujarat

\section{B. Industry in which women entrepreneurs have better prospects to grow}

In this section researcher is to probe existing relationship between perceived prospect of industry in which women entrepreneurs believe to have promising growth and the independent variable of current industry in which they own a business.

Table 4.49 and Chart 4.38 depicts that 61 per cent of women entrepreneurs believe that there exist high prospects in service industry, 53 per cent participating respondents believe that prospect is visible in trading industry and 43 percent of participating respondents believe the prospect in manufacturing industry for upcoming women entrepreneurs. 
TABLE 4.49

Table to represent 'Prospective Industry' for women entrepreneurs in Gujarat

\begin{tabular}{|l|c|}
\hline Prospective Industry for women entrepreneurs & Frequency \\
\hline Services & 246 \\
\hline Trading & 213 \\
\hline Manufacturing & 173 \\
\hline
\end{tabular}

Primary Source

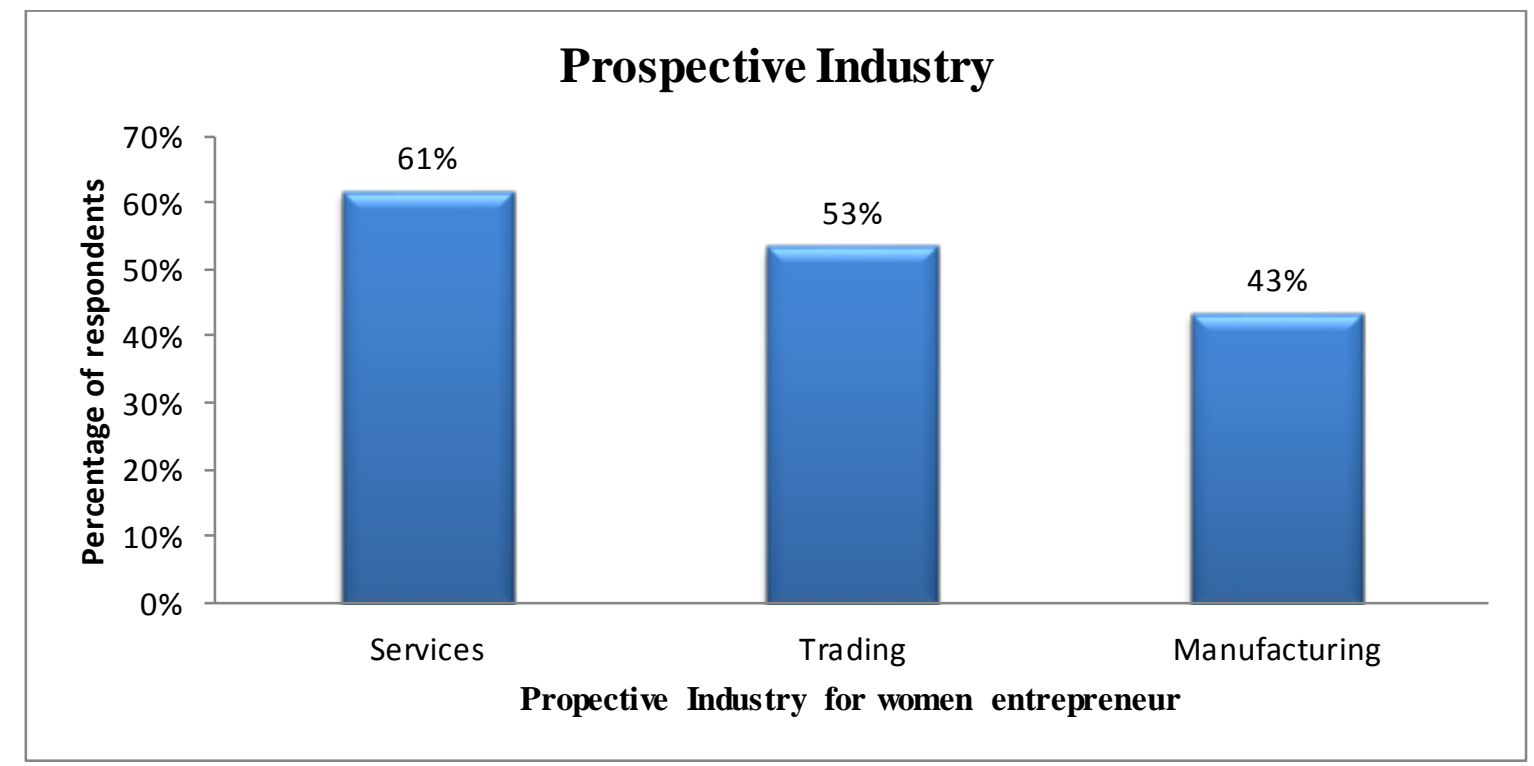

Primary Source

CHART 4.38

Bar Chart to represent 'Prospective Industry' for women entrepreneurs in Gujarat

\section{B.1. Prospect in various industries:-}

$\mathrm{H10}_{0}$ - Prospect in service and manufacturing business is independent of current type of industry in which women entreprene ur own their business venture.

H10 -Prospect in service and manufacturing business is independent of current type of industry in which women entrepreneur own their business venture.

This hypothesis can be studied by getting an insight of following two sub hypotheses. 


\section{SUB - HYPOTHESIS 1 -}

$\mathrm{H10A}_{0}$ - Prospect in service industry businesses is independent of current type of industry in which women entrepreneur own their business venture.

\section{H10A- Prospect in service industry businesses is not independent of current} type of industry in which women entreprene ur own their business venture.

A Chi-square test of independence is calculated comparing the frequency of respondents who believe that there exist better prospect in service industry and the frequency of their current industry in which they run business. A significant interaction is found $\left(\chi^{2}=10.45, \mathrm{p}<0.05\right)$. This signifies that prospect in service industry businesses is not independent of current type of industry in which women entrepreneur own and run their business venture. Hence null hypothesis is rejected.

Table 4.50 represents that those women entrepreneurs who currently own business in service industry believe to have confidence on 'Service Industry' to grow further and having bright prospects for especially women entrepreneurs. It is because women entrepreneurs think that service industry is providing number of upcoming opportunities especially in businesses such as beauty salon, retail of readymade garments, pre-school business and catering. In these businesses women have better prospects due to their better hold on customers and softer approach.

TABLE 4.50

Table to Represent the Relationship between the 'Prospect in Service Industry' and 'Type of Current Industry' in which Women Entrepreneur own business

\begin{tabular}{|c|c|c|c|c|}
\hline & \multicolumn{2}{|c|}{$\begin{array}{l}\text { Growing Business Industry - } \\
\text { Services }\end{array}$} & \multirow[b]{2}{*}{ Total } \\
\hline & & Yes & No & \\
\hline \multirow{3}{*}{$\begin{array}{l}\text { Type of } \\
\text { Industry }\end{array}$} & Manufacturing & 77 & 71 & 148 \\
\hline & Service & 153 & 71 & 224 \\
\hline & Both & 16 & 13 & 29 \\
\hline \multicolumn{2}{|l|}{ Total } & 246 & 155 & 401 \\
\hline
\end{tabular}

Primary Source 


\section{SUB - HYPOTHESIS 2 -}

\section{$\mathrm{H1OB}_{0}$ - Prospect in manufacturing industry is independent of current type of industry in which women entrepreneur own their business venture.}

H10B- Prospect in manufacturing industry is not independent of current type of industry in which women entrepreneur own their business venture.

A Chi-square test of independence is calculated comparing the frequency of respondents who believe that there exist better prospect in manufacturing industry and the frequency of their current industry in which they run business. A significant interaction is found $\left(\chi^{2}=25.384, p<\right.$ 0.05). This highlights the dependence of the perception of prospect in manufacturing industry on the current industry in which women entrepreneurs run their business. Hence null hypothesis is rejected.

Table 4.51 represents that those women entrepreneurs who already own a business in manufacturing industry have high expectations of growth in manufacturing industry especially in business activities like manufacturing of handicraft based items and farsaan (Snacks) making business activities especially in Gujarat as a market. It is perceived because of the fact that those women entrepreneurs who are already in manufacturing industry are well aware about the complexities associated to function in a manufacturing industry. They are accustomed to these complexities and are well aware of the upcoming opportunities women entrepreneurs have in this industry.

TABLE 4.51

Table to Represent the Relationship between Perception of Women Entrepreneurs to have Better Prospects in Manufacturing Industry and Their Current Industry in Which They Actually Run their Current Business

\begin{tabular}{|c|c|c|c|c|}
\hline & \multicolumn{2}{|c|}{$\begin{array}{c}\text { Growing Business Industry - } \\
\text { Manufacturing }\end{array}$} & \multirow[b]{2}{*}{ Total } \\
\hline & & Yes & No & \\
\hline \multirow{3}{*}{$\begin{array}{l}\text { Type of } \\
\text { Industry }\end{array}$} & Manufacturing & 83 & 65 & 148 \\
\hline & Service & 72 & 152 & 224 \\
\hline & Both & 18 & 11 & 29 \\
\hline \multicolumn{2}{|l|}{ Total } & 173 & 228 & 401 \\
\hline
\end{tabular}

Primary Source 
An analysis of H10A and H10B brings us to the conclusion that in case of H10 null hypothesis is rejected.

\section{The business activities having growth prospects for women entrepreneurs in Gujarat}

When the respondents were asked their opinion about the business activities having bright prospects for women entrepreneurs in Gujarat, respondents are observed quoting prospects majorly in beauty salon (74 per cent), other businesses (73 per cent), handic raft based businesses (70 per cent), readymade garment retail outlet (66 per cent), pre-school business (60 per cent), catering (57 per cent), and farsaan (snacks) making units (55 per cent). Few respondents believed to have view scope in event management business (44 per cent), retail stores (36 per cent), IT services and image building consultancy (27 per cent each), printing business (23 per cent) and grocery retail outlet (21 per cent).

It is noteworthy that in other form of businesses, as per Table. 4.52 and Chart 4.39, most respondents (66 per cent) felt that women have prospect in all those business in which she has interest and know-how.

TABLE 4.52

Table to represent 'Prospective Business Activity' for women entrepreneurs in Gujarat

\begin{tabular}{|l|c|}
\hline \multicolumn{1}{|c|}{ Prospective Business Activity } & Frequency \\
\hline Catering & 230 \\
\hline Pre - School & 243 \\
\hline Readymade Garments & 264 \\
\hline Beauty Parlor & 299 \\
\hline Grocery Retail Outlet & 86 \\
\hline Event Management & 175 \\
\hline Farsaan Making & 219 \\
\hline IT Services & 110 \\
\hline Printing & 92 \\
\hline Retail Stores & 144 \\
\hline Image Building Institution & 108 \\
\hline Handicraft based manufacturing unit & 282 \\
\hline Others & 294 \\
\hline
\end{tabular}

Primary Source 


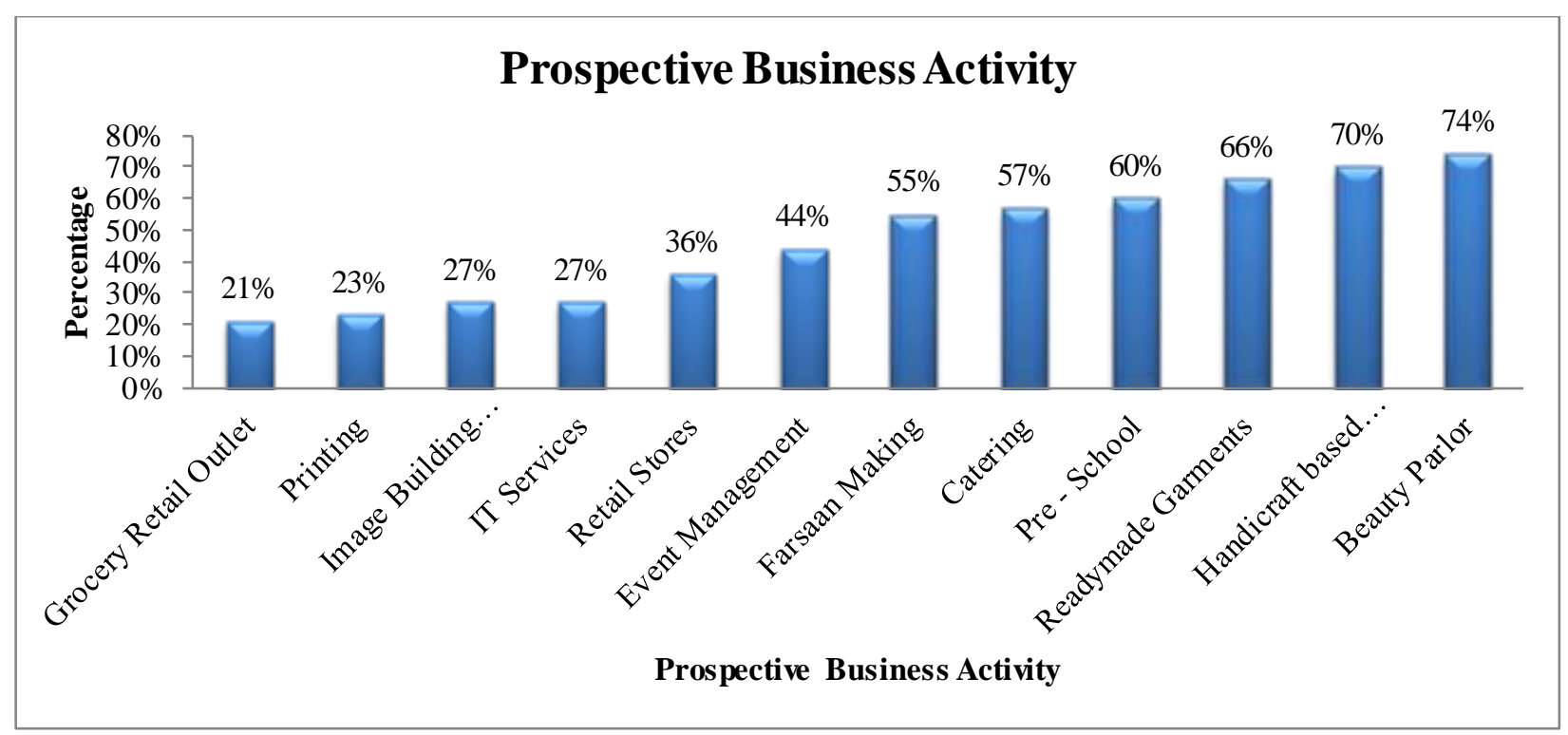

Primary Source

CHART 4.39

Bar Chart to represent 'Prospective Business Activity' for women entrepreneurs in Gujarat

Irrespective of current industry of owned business, women entrepreneurs strongly believe to have carved a niche in beauty salon business due to its ease, necessity of no special space to start business and less capital requirement as criteria to start this business.

Gujarat being well known for its art and culture has special scope for handicraft based businesses for local artisans. Government of Gujarat, event management organizers and various NGOs are found actively nurturing this form of art and motivating women entrepreneurs to transform their this form of art into MSME business units by way of giving them various platforms like regular exhibitions organized by Craftroots (An NGO) at 'Ahmedabad haat', exhibitions organized by Shrujan (An NGO) at 'Bhuj haat', exhibitions like organization of annual Vibrant Garima seminar cum exhibition, 'Pal Women and Kids Expo-2016' organized by Pal Events and various regularly organized 'hastkala mela' to sell their produces. Hence almost 70 per cent of respondents find better scope in handicraft based businesses.

As per Table 4.53 it is noteworthy that in 'Prospective Business Activity - Others' which is favored by 73 per cent of women entrepreneurs, 66 per cent of women entrepreneurs believe that women may start their venture in the field in which women has interest and knowledge. 
Researcher is not able to include this in the mainstream 'Prospective Business Activity' because it does not include any specific business activity signified by respondents. But, as it has been favored by most of the respondent's researcher makes it a point to highlight this opinion. It can be considered as an important indicator for entrepreneurship developing agencies like National Institute for Entrepreneurship and Small Business Development (NIESBUD) to target identifying the field of interest for women entrepreneurs and then design any training programme to be effective.

TABLE 4.53

Table to represent 'Prospective Business Activity-Others' for women entrepreneurs in Gujarat

\begin{tabular}{|l|c|c|}
\hline \multicolumn{1}{|c|}{ Prospective Business Activity - Others } & Frequency & Percentage of respondents \\
\hline $\begin{array}{l}\text { The field in which women has interest and } \\
\text { knowledge }\end{array}$ & 263 & $66 \%$ \\
\hline Diamond Merchant/Jewelry Merchant & 4 & $1 \%$ \\
\hline Fashion Boutique & 7 & $2 \%$ \\
\hline $\begin{array}{l}\text { Hobby Classes/ Coaching Classes/ training } \\
\text { classes }\end{array}$ & 4 & $1 \%$ \\
\hline Gruh Udyog/Packed Food & 6 & $1 \%$ \\
\hline Interior Designing/Consultation Services & 5 & $1 \%$ \\
\hline Machinery based manufacturing & 2 & $.5 \%$ \\
\hline Trading/Export Import & 1 & $.2 \%$ \\
\hline Photography Studio & 2 & $.5 \%$ \\
\hline
\end{tabular}

Primary Source

Studying the data brings us to the conclusion that in Gujarat possible problems which become deterring factor for women to start their own ventures and manage their own business are noteworthy and worth studying to bring solution to so that such an environment can be created which pulls women's attention to this field of occupation and women may go hand in hand with the male counterpart to empower the economic scenario of the nation.

The important findings and suggestions form another important section of this study which has been discussed in next chapter. 


\section{CHAPTER - V}

\section{Findings, Suggestions and Conclusion}

\subsection{Findings}

At the outset of the study possession of raw information of entrepreneurship, MSMEs and women entrepreneurship as terminology or field of study has taken a big leap during the course of study and transformed into knowledge. This has enabled researcher to present this piece of work in form of report as an effort to add value to the existing knowled ge of all three field of study with special reference to MSMEs in the State of Gujarat. Noteworthy inputs received from industry experts, academicians and NGO volunteers working to strengthen women entrepreneurs of the state and an unconditional cooperation extended by participating respondents makes this report even more worthy to be studied. Gujarat scenario of women entrepreneurship which was less reported by way of a thorough state wide research is worth reporting. There exist some remarkable enabling factors, immediate solution seeking problems and absolutely colossal opportunities which need to be detailed. After data analysis and interpretation the following major findings have been drawn:-

1. There is observed dominance of women entrepreneurs aged between 36-45 years (35 per cent) and 25-35 years (34 per cent) against the age group of below 25 years, 45-55 years and above 55 years of age group.

2. Women entrepreneurs in MSME sector of Gujarat are fairly educated with maximum women entrepreneurs (43 per cent) holding graduation degree followed by 25 per cent 
women continuing their study up to post graduation. In total 68 per cent of women entrepreneurs hold a degree of graduation or above.

3. Majority i.e. 81 per cent of women entrepreneurs are married.

4. 58 per cent of women entrepreneurs have husbands with highest qualification of graduation or above.

5. 45 per cent of women entrepreneurs have fathers with a highest qualification of graduation or above.

6. The data represents a grey picture of education level of mothers of the women entrepreneurs which shows that only 26 per cent of women entrepreneurs have mothers possessing a highest educational qualification of graduation or above. Whereas majority women entrepreneurs (27 per cent) mothers have a highest educational qualification of below matriculation.

7. Husbands (49 per cent) and fathers (52 per cent) of majority of the women entrepreneurs own business units in MSME sector.

8. Mother of majority (79 per cent) of women entrepreneurs are home makers.

9. Majority of the women entrepreneurs (67 per cent) have one or the other family member (brother, sister, brother-in-law, sister-in-law, father-in-law, mother-in-law, uncles, aunts etc besides father and husband) who has prior business experience. Out of these 67 per cent respondents, 42 per cent of respondents have received desired guidance and assistance while starting the new venture. But 25 per cent of respondents disagree to have received any assistance.

10. Majority of the women entrepreneurs (78 per cent) have started their business by self so to be showing go getter attitude.

11. More than 75-80 per cent of respondents are pursuing entrepreneurship due to pull factors like the everlasting desire to start one's own business (52 per cent), due to the interest generated because of belonging to a business family (18 per cent), the passion in respective business activity or industry (14 per cent) and the factor of firm confidence on the business plan (8 per cent). Therefore it is established in finding of this study that women entrepreneurs in Gujarat are inclined towards business on account of 'Pull Factor' rather than 'Push Factor'.

12. Also, for 32 percent of women entrepreneurs the reason to start business is a push factor; most important of them is weak financial condition.

13. Three important facts are unleashed by the statistics of year of establishment. First is the growth trend showing the augmentation of number of business ventures started by 
women entrepreneurs with every passing five years starting from 1985 till 2015. Second fact is, massive growth of women owned businesses in the year 2011-2015 indicates that the combined efforts of government and society is enabling women to think out of the box and take up the charge of one's own destiny by starting business establishments. Third and most vital fact is 52 per cent (a sum of businesses established from before 1985 to 2010) of women owned businesses are established for more than five to ten years now and still chasing the path of success indicates the sustainability women owned business ventures have.

14. A massive 56 per cent of respondents are observed having their business being run in service sector. 37 per cent of respondents have their business ventures in manufacturing sector and 7 per cent of respondents have their establishment in both the sectors.

15. It is observed that in manufacturing sector majorly (19 per cent) of respondents are engaged in home based manufacturing of Handicraft items/Handmade Jewelry/Medicinal Products for Sale etc followed by (15 per cent) respondents who are into the business of manufacturing customized cloths. Besides this other respondents belong to businesses like food processing unit, multiple products making, jewelry merchant (gold or diamond jewelry manufacturing), heavy manufacturing industries like products like hydraulics, machinery goods etc and spices production.

16. Business activities in service industry are observed to be professional beauty and wellness salon, Pre School / IT Learning Centers/ Hobby Centers / Coaching Institutes, involved into multi-business activities, consultancy services and being an agent to specific product like Amway, Oriflamme, Ektra, travel and tour planning business, event management and photography based services and IT solution business.

17. Gujarat finds maximum existence of women owned businesses in micro enterprises (82 per cent) followed by small enterprises (15 per cent) and medium enterprises (3 per cent) with a substantial difference.

18. Mostly respondents are observed owning a retail business (33 per cent). This has huge spread in Gujarat. This is because of ease of starting this form of business.

19. There is significant shift from micro to small and medium enterprises with the increasing age among the women entrepreneurs of the state. It is due to higher need of achievement among women entrepreneurs with increasing age. 
20. Size of business of women entrepreneurs is dependent on their education level. Micro sector observes participation of women entrepreneurs who are illiterate to those whose education is up to post graduation. Small and medium enterprises do not observe any participation from illiterate women entrepreneurs. They (illiterate women) have entrepreneurial participation only limited to micro sector. Small and medium enterprises observe maximum participation from those women entrepreneurs who have a minimum education level of graduation or beyond. This is due to two fold effects: - 1) there is need of enhanced knowledge with increasing size of businesses which leads women to pursue higher education and 2) higher education generates in individual an elevated need of achievement and hence they may start-up their venture as a micro enterprise but eventually aims to grow their businesses to small / medium enterprises or beyond.

21. There does not exist any significant relationship between size of business and husband's occupation.

22. More than half of the respondents' (53 per cent) confirm that their business venture is registered against 47 per cent of respondents who still have to register their business.

23. Women entrepreneurs have mostly (65 per cent) been relying on personal savings as seed capital while starting a business followed by borrowing from family/relatives (27 per cent). It is followed by bank credit (16 per cent), Local Creditors (3 per cent) and other sources (2 per cent).

24. Majority of the women entrepreneurs ( 41 per cent) believe that starting the business was slightly difficult, 28 per cent of respondents concur that it has been difficult, 17 per cent of respondents belief it to be moderate and 14 per cent of respondent considers it to be very easy.

25. 76 per cent of women entrepreneurs have not undergone any kind of 'Entrepreneurship Development Programme' (EDP) majorly because of lack of awareness.

26. 24 per cent of women entrepreneurs agreed to have attended EDP whereas majority of them i.e. 5 per cent each have been observed agreeing upon (i) the fact that EDP has been of great value as it helped them to successfully start their business and (ii) that after attending EDP they observed an increase of 10 - 15 per cent of profit growth in their business. 
27. Majorly EDP has not been observed playing expected role in the state because there still lacks awareness among women with respect to EDPs whether organized by district level, state level or national level institutions.

28. Important enabling factors for women entrepreneurs are 'Education' (83 per cent), followed by 'Family' (77 per cent), 'Inner zeal and will power' (75 per cent), 'Finance' (62 per cent) and 'Prior Experience' (61 per cent).

29. 89 per cent of those women entrepreneurs who believe that they lack technological skills also believe 'Education' to be one of the most important enabling factors for women to run a business and survive in it successfully.

30. In Gujarat women entrepreneurs face maximum of general financial problems followed by financial problems due to personal interest and at last socio-financial problems.

31. As the age increases this problem increases till the age of 45 . 36 years of age to 45 years is the age bracket where almost 85 per cent of women entrepreneurs are observed facing this problem due to increased family and business responsibilities. After this stage from the age group of 46 years and beyond when children are out of their education or grown up, they (children) also become a helping hand in business of their mother and hence contribute in managing the business which lessens the problem of dual role in family and business for women entrepreneurs.

32. Those women entrepreneurs who agree to be ignorant about banking procedures and formalities also tend to be agreeing that they possess a poor knowledge of government schemes. This reflects that personal characteristics of women entrepreneurs play an instrumental role when they run the business and make an effort to sustain in it.

33. Ignorance about banking procedures and formalities is found more in women aged between 36-45 years of age (67 per cent) against other counterparts. It is due to the fact that during this period women remain more dependent on their husbands for financial matters and pay less attention on and eventually generates ignorance about banking procedures and formalities.

34. The problem of poor knowledge of financial management is found prevailing in the women entrepreneurs with lesser education like illiterate (75 per cent), below matriculation (67.50 per cent) and matriculation (76 per cent). Women entrepreneurs with higher education are found having lesser problems related to poor knowledge of financial management. 
35. Important prospective factors, according to most of the women entrepreneurs (80 per cent each), for women to grow in the field of entrepreneurship is (a) increasing number of successful women entrepreneurs in the society and (b) increasing awareness among the women about the economic independence.

36. Out of the important problems faced by women entrepreneurs, few are general problems (lack of working capital and cut throat competition) which are faced by all (irrespective of gender) those who are involved in business as an occupation, but there are few imperative women specific problems also, as represented in Fig. 5.1, which are faced more by women entrepreneurs over men counterpart. These are dual role in home and business, poor knowledge of government support schemes, ignorance about banking procedures and formalities, poor knowledge of financial management, lack of leisure time and lack of technological skills.

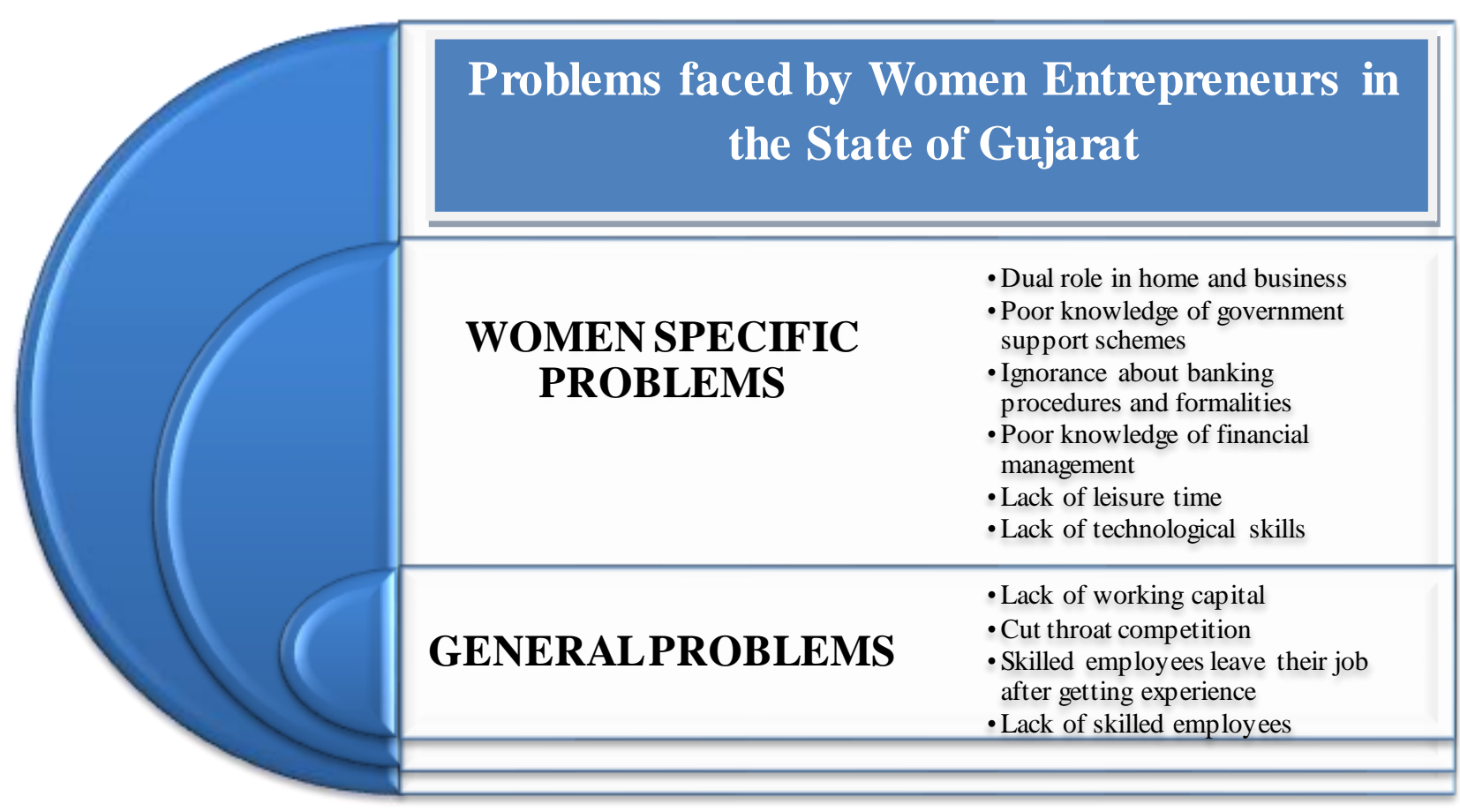

Primary Source

FIG 5.1

Problems faced by Women Entrepreneurs in the state of Gujarat

37. Those women entrepreneurs who currently own business in service industry believe to have confidence on 'Service Industry' to grow further and have bright prospects especially for women entrepreneurs. 
38. Those women entrepreneurs who own a business in manufacturing industry have high expectations of growth in manufacturing industry especially in business activities like manufacturing of handicraft based items and farsaan (Snacks) making business activities especially in Gujarat as a market.

39. Business activities having bright prospects for women entrepreneurs in Gujarat are majorly beauty salon (74 per cent), other businesses especially those of woman's interest and skill area (73 per cent), handicraft based businesses (70 per cent), readymade garment retail outlet (66 per cent), pre-school business (60 per cent), catering (57 per cent), and farsaan (snacks) making units (55 per cent). Few respondents believed to have view scope in event management business (44 per cent), retail stores (36 per cent), IT services and image building consultancy (27 per cent each), printing business (23 per cent) and grocery retail outlet (21 per cent).

\subsection{Suggestions}

Women entrepreneurs are not able to easily perceive the idea of getting into the role of entrepreneurs because of the discussed problems. Considering the problems of women entrepreneurs the following thought provoking and practical suggestions are given for improvement of women in Gujarat-

1. Time-management - For the problem of dual role in home and business the most important contribution should come from self. Women should manage their time judiciously by planning a weekly or daily time-table.

2. Making family self-sufficient - To deal with the problem of dual role in home and business, women should start making their family members, especially husband and children, self sufficient, so that they (husband and children) can manage their and household day to day tasks on their own.

3. Managing home and business - Cooperation from husband and other family members can be sought by the women entrepreneurs to manage home and business effectively.

4. Usage of ICT and other tech enabled devices - It can also get a solution by making use of suitable technologies which will enable women to manage her home and family 
responsibilities. Like the use of automated equipments for domestic use, use of upgraded technological installations at workplace can prove miraculous in managing work and home.

5. Support from within - Women should have positive attitude, team building spirit, courage, guts of facing the failure and independent in thinking to succeed in their business ventures.

6. Society support - The society needs to extend its cooperation to a woman in the same way a man gets cooperation from his family and society when he leaves home to earn bread and butter. This will greatly encourage women to effectively manage home and business.

7. Spouse support is paramount - In case of a married woman, a husband becomes most important person whom she looks upto to get a support of shared responsibilities for household and business work. During the survey most women quoted that they receive immense support from husband to carry out day to day activity. This proves that this is a workable solution. Therefore researcher recommends the husbands of working women and more specifically women entrepreneurs, to extend immense support to the woman of his life to successfully handle her (or their; in case business is run by both the husband and wife) business venture.

8. Assistance of elderly members - Elderly members of the family, especially those who are retired from their jobs can also be of great help to the woman of the family by providing a helping hand in managing either business or home in their little ways wherever they can. It can be eventually keeping them busy even in their retiring ages which many times give them a sense of pride and sense of self actualization.

9. Widening of micro-credit facilities - Yogendrarajah (2011) in his study based in South Africa indicated a positive relation between micro-credits and women entrepreneurship hence the need of the hour is to widen micro-credit facilities to women entrepreneurs which eventually can create magic to sort out problems faced by them.

10. Reform of financial policies and regulatory frameworks - Reform of financial policies and regulatory frameworks like removal of collateral security and ease of business registry process when women entrepreneurs seek financial assistance from the bank and/or other designated institutions (World Bank).

11. Women centered innovative financial products - Bringing innovative women entrepreneurs centered products by banks for instance alternative forms of collateral 
to access financing such as debentures, bills of sales and jewelry as developed by Access Bank of Nigeria in collaboration with International Finance Corporation (IFC) to bring financial solution to women entrepreneurs of Nigeria (World Bank).

12. Intelligent usage of finance - Women should intelligently utilize the financial resources she is able to procure as credit from either government funds or any other source.

13. Financial assistance as Corporate Social Responsibility Acts - In Mundra while covering Kutch region, it came to the notice of researcher that the companies are training women to generate varied sorts of skills among them so that these women eventually generate income by making use of these skills. As part of 'Corporate Social Responsibility' companies may extend working capital facility too to these marginal entrepreneurs. This can be done by linking these women entrepreneurs to the banks with which company deals. These banks may provide micro credits to these women entrepreneurs. For any default on credits faced by these banks from these marginal women entrepreneurs, company may repay as part of CSR act. Not only this, the company may form specialized teams which may consult these women entrepreneurs on various aspects like finance, raw material procurement, linking to the industry players, rendering training services etc.

14. Subsidized spaces - Shopping Centers shall be provided to women entrepreneurs at subsidized rates.

15. Equal treatment of government representatives and agencies - Government Exhibitions which are organized for small entrepreneurs should give relaxation to small women entrepreneurs and should deal impartially.

16. Credit with longer repayment period - Raw Materials to the manufacturer women entrepreneurs and finished goods to the distributor women entrepreneurs should be given on credit with longer repayment period options.

17. Aggressive Marketing - Aggressive TV/Radio/Newspaper/Posters/Hoardings/Bill Board commercials will be the best solution to curb the problem poor knowledge of government support schemes as women hardly finds any such medium being used for information circulation to industry wide women entrepreneurs of each level about the schemes pertaining to women entrepreneurs'. Unless the beneficiary knows about the schemes in place, there is not any purpose of bringing one in the system.

18. Women Centered Business Forums - The business forums for instance Business Women's Wing, Gujarat Chamber of Commerce and Industries (BWW-GCCI), TiE 
Ahmedabad, FICCI Ladies Organization and many more needs to play instrumental role in bring the women entrepreneurs of different parts of the society together and disseminate information on schemes and policies for MSME owners and women entrepreneurs on regular basis.

19. Publicizing their work - The family members and near and dear ones of the women entrepreneurs may be of immense support to them by publicizing the work of women entrepreneurs among their social circle so to form prospective client base for them.

20. Beneficiary Outreach Programme - Role played by BWW-GCCI, Entrepreneurship Development Institute of India, Centre for Entrepreneurship Development, SEWA, FICCI-FLO are phenomenal. But many times these remain untouched from the real set of beneficiary especially those who are away from the cities where these institutions are located. For this reason aggressive marketing done by these institutions for spreading information on variety of scheme for the benefit of women entrepreneurs needs to be practiced so that actual beneficiaries get the benefit.

21. Collaborations with banking institutions - The problem of ignorance towards banking procedures and formalities and the problem of financial management can be better addressed and catered by banking institutions. Training Institutions such as EDII, CED, BWW-GCCI, FICCI-FLO, SEWA, TiE-Ahmedabad may come in collaboration with banking institutions and identified set of women entrepreneurs can be provided training to cope up of these problems.

22. Role Model Women Entrepreneurs - As per the revelation of Table 4.52 and Fig 4.39 increasing number of successful women entrepreneurs in the state needs to play supportive role to women entrepreneurs and share with them or train them in skills required to address the problems of ignorance towards banking procedures and formalities and the problem of financial management, problem of lack of leisure time.

23. Experience Sharing Seminars - Government should create a platform by the participation of agencies such as NIESBUD, CED, FICCI-FLO, EDII etc to conduct and organize 'Experience Sharing Seminars' where established successful women entrepreneurs become resource person for knowledge and experience sharing to equip the women entrepreneurs in need to tackle problems in discussion.

24. 360 Degree Support - To cater to the problem of lack of technological skills a 360 degree support is needed from family, government agencies and training institutions, ICT companies, successful women entrepreneurs who are in a sense role model for 
upcoming and growing women entrepreneurs and most importantly an initiative from self to learn ICT enabled technological skills for the betterment of business functions.

25. ICT Subsidies - Women entrepreneurs many times due to lack of interest do not take active interest in learning ICT skills. Government in this case may make effort to engender an inclination in women entrepreneurs to learn and take interest in ICT, by facilitating ICT subsidies (Torero and von Braun, 2005); (World Bank) as part of various other initiatives like Digital India and Stand-up India.

26. Vocational training to rural women and youth - Women face problems of skilled employees' high attrition rate upon having learned the business skills and problems of non availability of skilled employees. To bring a solution to it government should focus upon accelerating the number of vocational training especially to rural youth and moreover to rural females.

27. Interlinking of livelihood schemes with women owned business units - According to the inputs of women entrepreneurs there should be engendering of an interlink between livelihood projects of the state for instance Mission Mangalam Project, can create magic and dual solutions (a) to the women entrepreneurs by providing them readily available skilled labor pool and (b) to the needy rural unskilled, who gets skilled as a result of livelihood trainings, by providing them much required job opportunities in MSME sector and in this case especially job opportunities with women owned enterprises.

28. Concentration on prospective industries - Government should enable women to open up ventures in identified prospective business ventures by accelerating the training programmes and by easing the procedural requirements in this field.

In nutshell the researcher is proposing 'Chieffacilitator Process' as a possible solution. It is a process identified on the basis of judgement of researcher by studying three aspects in the study - Enabling Factors, Problems faced and Prospective Factors. It shows a cyclical process of creating an empowering environment to women entrepreneurs which starts with the very basic entity i.e. the woman entrepreneur 'Self'. Second important facilitator is 'Family' as identified in the enabling factors which has to play specific role specified in the process Fig. 5.2. Third important entity is 'Government bodies' and 'NGOs' and appeals them to play specific role as mentioned in the process which will further empower the women entrepreneur. Last but not the least is the already established women entrepreneurs who have 
proved to be immense source of motivation so to be called the 'Role Model' as found in the prospective factors (Section 5.1.35).

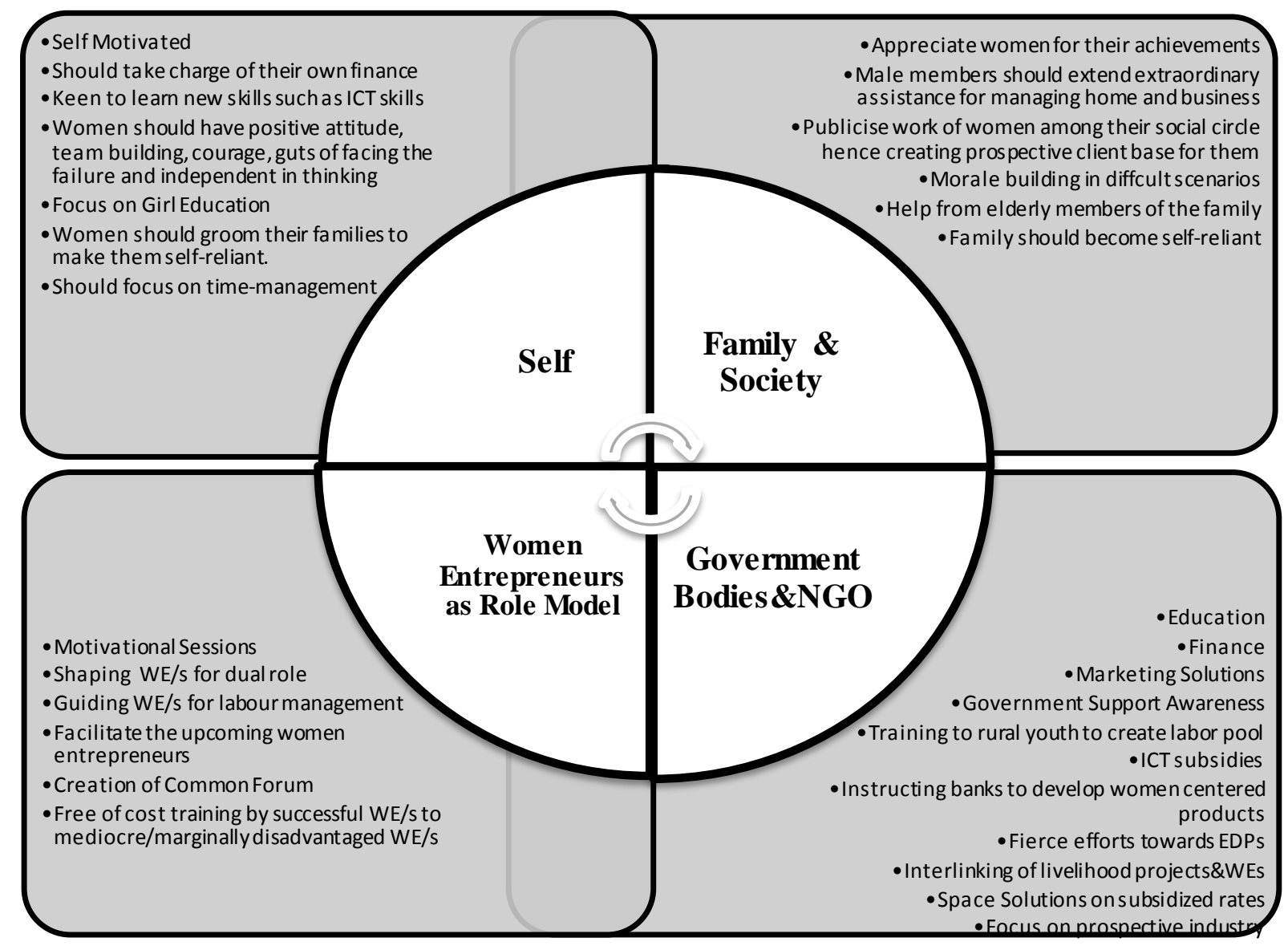

Primary Source

FIG. 5.2

\section{Chief Facilitator Process}

If the chief facilitators play specific roles prescribed in the 'Chief Facilitator Process' as represented in Fig.5.2, the status of women entrepreneurs can be improvised from the current. Then it is believed that Gujarat will also be able to observe industry wide equal economic contribution from women entrepreneurs. 


\subsection{Conclusion}

Gender gap in entrepreneurship is one of the major research interests for most of the economic researchers. Especially in underdeveloped and developing economy it is firmly accepted that women entrepreneurship is one best alternative to resolve the problems arising from poverty. Not only that but it has the potential to create new jobs, nurture creativity and according to few experts it greater female economic independence leads to geopolitical stability and world peace (Caplan, 2011). An enriched women ent repreneurship does not only prove to an economic solution but becomes solution to various social retardations like crime against women (human trafficking, domestic violence, glass ceiling and varied discriminatory practices etc) and engenders personal autonomy and empowerment.

The researcher has carefully studied the enabling factors, the important problems both general and women specific and the prospective factors which according to the participating women entrepreneurs have encouraged the women entrepreneurs to keep going in their business endeavor. In case of women entrepreneurs in Gujarat education, family and inner zeal and will-power are vital enabling factors which elevate their motivation scale to perform in the state. Most hurdling limiting factors have been dual role in home and business, poor knowledge of government support schemes, ignorance about banking procedures and formalities, poor knowledge of financial management, lack of leisure time and lack of technological skills. With regard to prospect, researcher found that there exist ample prospects in services sector over manufacturing and other trading business.

Researcher has filtered the overlapping points and created 'Chief Facilitator Process'. The desired economy and social equality to women is achievable if the 'Chief Facilitator Process' is adopted and regulated with genuine efforts. 


\subsection{Scope for future research}

The current research is unique in portraying the picture of enabling factors, problems and some promising prospects eyeing women entrepreneurs of Gujarat. But there are many future scope of research which can be worked upon by the researcher to explore the sphere of entrepreneurship, MSMEs and women entrepreneurship as a whole.

a. There is scope of a comparative study on the basis of current research in between two states or few selected states to compare the problems and prospects of women entrepreneurship with special reference to MSMEs.

b. There are huge scope of in-depth study of problems and prospects of women entrepreneurship comparing the scenarios of two or more industries of one or more states.

c. An emphatic need of the hour is to broaden this study by conducting similar study with similar objectives but on a larger scale more specifically to conduct a nationwide study to represent an advanced picture of problems bothering women entrepreneurs, prospects welcoming women entrepreneurs and enabling factors persuading women entrepreneurs to pursue entrepreneurship more aggressively.

d. Research needs to be conducted comparing the status of enabling factors, problems and prospects of women entrepreneurship with male counterpart to throw light on difference between the scenario eyeing male and female entrepreneurs.

e. There are possibilities to broaden the aspect of this study by studying this phenomenon for two or more developing countries and more specifically BRICS nation. This kind of approach will enable to comprehend upon the deep rooted effectiveness of establishment of BRICS on ground level women entrepreneurs or male counterpart thereby rendering overall entrepreneurship as a phenomenon.

f. The scope can further be broadened by conducting the similar study to portray a comparative picture between developing and underdeveloped or developing and developed nations. This kind of approach will render to recognize the strengths and weaknesses of nations of different standing.

g. As mentioned in Section 3.7 of this research report, future researches of similar nature may consider collecting ordinal and interval data's which will allow the researcher to 
perform alternative forms of tests like most of the parametric tests like Mann-Whitney U-Test, Kruskal-Wallis test, independent t-test and ANOVA. 


\section{References}

Yogendrarajah, R. (2011). Empowering Rural Women through Micro-credit on poverty alleviation, Self Employment and Health Nutrition under Post War Development.Gumbard Business Review.6 (2).1-17.

World Bank, "Female Entrepreneurship: Program Guidelines and Case Studies", pp.1-65. http://siteresources.worldbank.org/EXTGENDER/Resources/FemaleEntrepreneurship Resour cePoint0411 13.pdf

Torero, M. \& von Braun, J. (2005).ICTs. Information and Communication Technologies for the Poor. The Potential of Telecommunications. IFPRI Issue Brief 40. Washington, DC: International Food Policy Research Institute. Retrieved from http:/www.ifpri.org/pubs/ib/ib40.pdf

Caplan, S (2011, Aug 18). The Importance of Women Entrepreneurs.Forbes Article.

Retrieved on $28^{\text {th }} \quad$ December, $\quad 2016$ from http://www.forbes.com/sites/shericaplan/2011/08/18/the-importance-of-womenentrepreneurs/\#257aae576090 


\section{List of references}

[1] Rama M (2003) 'Globalization and the workers in Developing Countries' World Bank Policy research working paper- 2958.

[2] Naidu V, (2009, Jan 9) 'Promoting Entrepreneurship in India', The Economic Times.

[3] Punj S, Arun MG (2016, April 20) "Where are the jobs” India Today In.

[4] Knotek, Edward S., II. (2007, Jan 11) "How Useful Is Okun's Law?" Federal Reserve Bank of Kansas City, Economic Review, vol. 92, no. 04, pp. 73-103.

[5] Gupta, G.S. (2002). Economic Fluctuations and Stabilization Policies. Presented at the Sixth Dr. D.K.Shukla Memorial Lecture, Department of Economics, M.S.University Baroda on December28, 2002.

[6] Faria J.R, Cuestas J.C, Gil-Alana Luis A. (2009) 'Unemployment and entreprneurship : A cyclical relation'. Economic Letters 105 (2009). Pg 318-320.

[7] Bokhari, A.A.H (2012) 'Entrepreneruship as a solution to Youth Unemployment in the Kingdom of Saudi Arabia' American Journal of Scientific Research. Issue 87 $\operatorname{Pg} 124$.

[8] Bygrave, W., Zacharakis, A. (2011) 'Entrepreneurship'. Pg 25-26. $2^{\text {nd }}$ Ed. John Wiley \& Sons Inc.

[9] Kritikos A. S, (2014) Entrepreneurs and their impact on jobs and economic growth. Pg.3 IZA World of Labor. DOI: 10.15185/izawol.8.

[10] Stam E \& Garnsey E.W (2007) "Entrepreneurship in Knowledge Economy" Pg 1. SSRN Electronic Journal. DOI : 10.2139/ssrn.1923098.

[11] U.S. Department of State/Bureau of International Information Programs Document.

[12] Desai V, (2014) 'The dynamics of Entrepreneurial Development and Management'. (5 ${ }^{\text {th }}$ ed) Himalaya Publishing

[13] Aspromourgos T (2012) 'Entrepreneurship, Risk and Income Distribution in Cantillon's Essai' pg.1

[14] Naude W, (2011), 'Entrepreneurship and Economic Development'. Series in Development Economics and Policy. Pg 5.Palgrave Macmillan

[15] The Economist (27 $7^{\text {th }}$ April, 2009). Entrepreneurship.

[16] Miryala, R.K \& Aluvala, R (2015). Trends, Challenges and Innovations in Management - Volume II. Pg. 62. Zenon Academic Publishing. 
[17] Ahmad N, Seymour R.G (2008) 'DEFINING ENTREPRENEURIAL ACTIVITY: Definitions Supporting Frameworks for Data Collection' OECD Statistics Working Papers, 2008/01, OECD Publishing, Paris.

[18] Aspromourgos T (2012) 'Entrepreneurship, Risk and Income Distribution in Cantillon's Essai' pg.1

[19] Gartner, W. B. (1988). "Who is an entrepreneur?" is the wrong question. American Journal of Small Business, /i(Spring), 11-32.

[20] Schumpeter, J A. 1934. The Theory of Economic Development: An Inquiry into Profits, Capital, Credit, Interest, and the Business Cycle. Cambridge, MA.: Harvard University Press.

[21] Kirzner, I. M. 1973. Competition and entrepreneurship. Chicago: University of Chicago Press.

[22] Knight, F. H. ( 1921) Risk, Uncertainty and Profit. New York: Harper.

[23] Say, Jean Baptiste (1803). A Treatise on Political Economy, Philadelphia: Lippincott Grambo.

[24] Mokaya, S.O., Namusonge, M., and Sikaleih, D. (2012). The Concept of Entrepreneurship; In Pursuit of a Universally Acceptable Definition. Pg. 133. International Journal of Arts and Commerce. Vol. 1 No. 6. November, 2012.

[25] Filion, L.J. (2011). Defining the Entrepreneur. Dana, L.P (Ed). World Encyclopedia of Entrepreneurship(pp 41-52). Cheltenham, UK; Northampton, MA, USA: Edward Elgar

[26] Goswami, A., Dalmia, N. and Pradhan, M. (2008). Entrepreneurship in India. National Knowledge Commission Report - 2008.

[27] Amoros, J.E. and Bosma, N. (2014). Global Entrepreneurship Monitor 2013 Global Report. . Babson Park, MA, U.S.: Babson College; Santiago, Chile: Universidad del Desarrollo; Malaysia: Universiti Tun Abdul Razak; London, U.K: London School of Business and London, U.K.: Global Entrepreneurship Research Association.

[28] Sanjeevan, G. (2012). Present Status of MSME Statistics. The Journal of Industrial Statistics. 1 (2). 269-282.

[29] Economy, I.A.G (2004). Promoting SMEs for Development. $2^{\text {nd }}$ OECD Conference of Ministers Responsible for Small and Medium Sized Enterprises (SMEs). 3-5 June, 2004. Istanbul, Turkey. 
[30] IFC (2010). Micro, Small, and Medium Enterprises around the World: How Many are there, and What Affects There Count. World Bank/IFC MSME Country Indicators- 2010.

[31] MSME (2010). Report of Prime Minister's Task Force on Micro, Small, Medium Enterprises. January, 2010.

[32] IFC Report (2014). Improving Access to Finance for Women-owned Businesses in India.

[33] Development Commissioner-Micro Small Medium Enterprises. Government of India Website.

[34] Smith-Hunter, A. (2013). Women entrepreneurs in the global marketplace. Edward Elgar Publishing.

[35] Census India (2001). Gender Composition.

[36] Sharma, Y. (2013). Women Entrepreneur in India. IOSR-Journal of Business and Management. I5 (3). (Nov-Dec, 2013). PP 09-14.

[37] Economy, I. A. G. (2004). Women's Entrepreneurship: Issues and Policies.

[38] Cherukara, J. and Manalel, J. (2011). Evolution of Entrepreneurship Theories Through Different School of Thoughts. At the Ninth Biennial Conference on Entrepreneurship at Entrepreneurship Development Institute of India on Feb 16-18, 2011.

[39] Bula, O.H. (2012). Evolution and Theories of Entrepreneurship: A Critical Review of Kenyan Perspective. International Journal of Business and Commerce. Vol.1, No.11. 9pp-81-96).

[40] Down, S. (2010). Enterprise, Entrepreneurship and Small Business. Cornwall; UK. Sage Publication

[41] Barreira, J. (2010). Early Thinking and The Emergence of Entrepreneurship. In Urban, B. (Ed). Frontiers in Entrepreneurship (pp 1-32). Berlin, Germany:Springer-Verlag. DOI 10.1007/978-3-642-04502-8.

[42] Rocha, V.C. (2012). The Entrepreneur in the Economic Theory: From an Invisible Man Toward a New Research Field. FEP Working Papers. N.459 May, 2012.

[43] Casson, M. (2004). Entrepreneurship and the Theory of the Firm. Workshop on Alternative Theories of the Firm, ATOM. November 2002. Paris.

[44] Yu, T.F.L. (2001). Entrepreneurial Alertness and Discovery. Pp. 47-63. The Review of Autrian Economics. 14:1. Netherland. Kluwer Academic Publisher. 
[45] Luiz, J.M. (2010). Economic Perspectives of Entrepreneurship. In Urban, B. (Ed). Frontiers in Entrepreneurship (pp.63-84). Berlin, Germany: Springer-Verlag. DOI 10.1007/978-3-642-04502-8.

[46] Ebner, A. (2005). Entrepreneurship and Economic Development. Journal of Economic Studies. Vol. 32 No.3, 2005. pp. 256-274. Emerald Group Publishing. DOI 10.1108/01443580510611047.

[47] Berger, B. (1991). The Culture of Entrepreneurship. San-francisco, California: ICS Press.

[48] Jones, G. \& Wadhwani, R.D. (2006). Schumpeter's Plea: Rediscovering History and Relevance in the Study of Entrepreneurship. Harvard Business School Working Paper, 06-036.

[49] Frese, M. (2009). Toward a Psychology of Entrepreneurship - An Action Theory Perspective. Foundations and Trends in Entrepreneurship. Vol.5 No.6 (2009). DOI 10.1561/0300000028.

[50] UNCTAD (2005). Entrepreneurship And Economic Development: The Empretec Showcase. United Nations Conference on Trade and Development, Geneva, 2004.

[51] Hamilton, R.T. and Harper, D.A. (1994). The Entrepreneur in Theory and Practice. Journal of Economic Studies. Vol. 21. No. 6. (pp.3-18).

[52] Ostergaard, A. (2014). The Challenges of Measuring the Entrepreneurial Personality? A Methodological Approach. DRUID Society Conference, June 1618, 2014. CBS, Copenhagen.

[53] Thronton, P.H. (1999). The Sociology of Entrepreneurship. Annual Review of Sociology. Vol.25.(pp.19-46).

[54] Vu, D.L.N., Napier, N.K. and Hoang, V.Q. (2012). It Take Two to Tango: Entrepreneurship and Creativity in Troubled Time in Vietnam 2012. CEB Working Paper $N^{\circ}$ 12/022 2012. Université Libre de Bruxelles.

[55] Rauch, A., \& Frese, M. (2000). Psychological approaches to entrepreneurial success. A general model and an overview of findings. In C.L. Cooper \& I.T. Robertson (Eds.), International Review of Industrial and Organizational Psychology (pp. 101-142). Chichester: Wiley.

[56] Chell, E. (2008). The Entrepreneurial Personality - A Social Construction. Second Edition. Hove, East Sussex: Routledge (Taylor and Francis).

[57] Filion, L.J. (1998). Two Types of Entrepreneurs: Operator and Visionary Consequences for Education. Working paper no. 1998-11 September 1998 and 
presented at the Rencontres de St-Gall 1998 held in Elm (Switzerland), September 28 - October 2nd, 1998, published in Pleitner, H.J. (Ed.) 1998 Renaissance of SMEs in globalized economy, p. 261-270.

[58] PWC India (2014) 'Future of India- The Winning Leap' Pg 74. PWC.

[59] Audrestch D B \& Meyer N S (2009) 'Religion, Culture and Entrepreneurship in India' Paper presented in IPAA 2009 International Public Affairs Conference at Indiana University, Bloomington.

[60] Tripathi D (1971). Indian Entrepreneurship in Historical Perspective: A ReInterpretation. Pg - M 59. Economic and Political Weekly. Vol.6, No.22 (May 29, 1971).

[61] Hazen, Walter (2003). Inside Hinduism. Pg. 4 Miliken Publishing.

[62] Kumar A (2002). Encyclopedia of Teaching of Agriculture. Pg. 411. Anmol Publications. ISBN 978-81-261-1316-3

[63] Pahurkar, R. N. (2011). An empirical study of problems and prospects of entrepreneurship development through management education with special reference to university of Pune. Unpublished $\mathrm{PhD}$ Thesis. University of Pune.

[64] Tata Central Archives. Circa 1900. Jamsetji Nusserwanji Tata (1839-1904)

[65] Gopalakrishnan R (2014). The Legend and his legacy - The Tata Samaskar. Pg 42. Tata Review. Jan 2014.

[66] Shankar, R K (2009). The rise and rise of Indian Entrepreneurism. Tapasya - A Magazine by Indira Institute of Management, Pune. Monsoon Edition.

[67] Tabe, N \& Garriappa, S. (2013) Entrepreneurship Development in India Emergence from Local to Global Leadership. Kalpaz Publications. ISBN:978-817835-989-2.

[68] Komiya, R (1959). A Note on Professor Mahalanobis' Model of Indian Economic Planning. The Review of Economics and Statistics. Pp. 29-35.Vol. 41. No. 1 (Feb, 1959). The MIT Press.

[69] Essays, UK. (November 2013). Nationalization Of Banks In India The Economic Effect Economics Essay.

[70] Kotwal, A., Ramaswami, B., and Wadhwa, W. (2011). Economic Liberalization and Indian Economic Growth: What's the evidence? Discussion Paper 11-13. Indian Statistical Institute, Delhi.

[71] Ravi, S. (2014). What Drives Entrepreneurship? Some Evidence from India.Brookings Institution India Center, 14-15. 
[72] Secretariat, R. S. (2009). Global Economic Crisis and Its Impact on India. Occasional Paper Series (4).Rajya Sabha. New Delhi.

[73] Verick, S., \& Islam, I. (2010). The great recession of 2008-2009: causes, consequences and policy responses. Discussion Paper Series. IZA DP No. 4934.

[74] UNCTAD (2010). The Financial and Economic Crisis of 2008-2009 and Developing Countries. UNCTAD/GDS/MDP/2010/1. United Nations Publications.

[75] PwC and CII (2011). Innovation: Changing the MSME Landscape. PwC and CII Publication.

[76] CII and PwC. (2010). Creating Competitive SMEs. PwC and CII Publication.

[77] MSME Annual Report (2014-15), Government of India.

[78] Alsos, G.A., Jensen, R.S. \& Ljunggren, E. (2010). Women Entrepreneurs and the Global Environment for Growth. Brush, C.G., Bruin, A.D., Gatewood, E.J., Henry, C. (Ed). Gender and Entrepreneurship: revealing constructions and underlying processes - the case of Norway (pp. 40-56). Glos, UK. Edward Elgar Publishing Inc.

[79] Kelley, D.J., Brush, C.G., Greene, P.G., Litovsky, Y. (2014). GEM 2012 Women’s Report. . Babson Park, MA, U.S.: Babson College; Santiago, Chile: Universidad del Desarrollo; Malaysia: Universiti Tun Abdul Razak; London, U.K: London School of Business and London, U.K.: Global Entrepreneurship Research Association.

[80] Gender GEDI Executive Report 2014.

[81] Streefkerk, H. (1997). Gujarati Entrepreneurship - Historical Continuity Against Changing Perspectives. Economic and Political Weekly. 22 February, 1997.

[82] Gujarat Official State Portal. All About Gujarat.

[83] Gujarat Micro, Small and Medium Enterprises Report - 2013.

[84] NI-MSME Website.

[85] IIE Website.

[86] NSIC website.

[87] MSME Schemes (2016).

[88] MSME Schemes (2015).

[89] MUDRA Scheme (2015).

[90] State Bank of Travancore Website

[91] Women and Child Development Department Newsletter, Government of Gujarat. Vibrant Gujarat 11-13 January, 2015. 
[92] Commisionarate of WCD. Women and Child Development Department, GoG Website.

[93] GWEDC. Women and Child Development Department Website.

[94] Industries Commissionarate Website, GoG.

[95] Gujarat Chamber of Commerce and Industries Website

[96] Gujarat Industrial Development Corporation Website

[97] Express News Service (2016). Gujarat 'Women Only' Industrial Park: 76 Plots Allotted to Entrepreneurs at Sanand. The India Express Article on August 4, 2016.

[98] Baker, T., Aldrich, H.E., and Liou, N. (1997). Invisible Entrepreneurs: the neglect of women business owners by mass media and scholarly journals in USA. Entrepreneurship and Regional Development- An International Journal. (pp.221238). 9 (3).

[99] Buttner, E. and Moore, D. (1997). Women's Organizational exodus to Entrepreneurship: Self-Reported Motivations and Correlates with Success. Journal of Small Business Management 35(1) (pp.34-47). Retrieved from http://search.proquest.com/openview/7976a4b f8b53be57490ad225b9e2beb3/1?pqorigsite $=$ gscholar

[100] Anna, A.L., Chandler, G.N., Jansen, E. and Mero, N.P. (2000). Women Business Owners in Traditional and Non-Traditional Industries. Journal of Business Venturing. 15 (3) . (pp. 279-303). DOI: 10.1016/S0883-9026(98)00012-3.

[101] Coughlin, J.H. and Thomas, A.R. (2002). The Rise of Women Entrepreneurs: People, Process and Global Trends ( $\left.1^{\text {st }} E d\right)$. Connecticut, London: Quorum Books.

[102] Aldrich, H.E. and Cliff, J.E. (2003). The Pervasive Effects of Family on Entrepreneurship: Toward a Family Embeddedness Perspective. Journal of Business Venturing. 18 (5). (pp-573-596).

[103] Minniti, M. and Arenius, P. (2003). Women in Entrepreneurship. Presented at the Symposium of 'The Entrepreneurial Advantage of Nations', First Annual Global Entrepreneurship Symposium on $29^{\text {th }}$ April, 2003. New York: United Nations Headquarters.

[104] OECD (2004). Women Entrepreneurship: Issues and Policies. $2^{\text {nd }}$ OECD conference of ministers responsible for small and medium sized enterprises (SMEs). 3-5 June, 2004. Istanbul, Turkey.

[105] Carter, N. M. \& Brush, C. G. (2004). Gender. Gartner, W. B., Shaver, K. G., Carter, N. M \& Reynolds, P. D. (Eds). Handbook of Entrepreneurial Dynamics- 
The Process of Business Creation.(pp.12-25). Thousand Oaks: California. Sage Publications.

[106] Brush, C.G. and Manolova, T.S. (2004). Personal Background. Gartner, W. B., Shaver, K. G., Carter, N. M \& Reynolds, P. D. (Eds). Handbook of Entrepreneurial Dynamics- The Process of Business Creation.(pp.78-93). Thousand Oaks: California. Sage Publications.

[107] Matthews, C.H. and Human, S.E. (2004). Family Background. Gartner, W. B., Shaver, K. G., Carter, N. M \& Reynolds, P. D. (Eds). Handbook of Entrepreneurial Dynamics- The Process of Business Creation.(pp.94-103). Thousand Oaks: California. Sage Publications

[108] Richardson, P., Howarth, R. and Finnegan, G. (2004) The challenges of growing small businesses: insights from women entrepreneurs in Africa. Geneva: ILO: IFP/SEED Working Paper No. 47, Series on Women's Entrepreneurship Development and Gender Equality (WEDGE).

[109] Aspray, W. and Cohoon, J.M. (2007). Gender difference in firm size, growth and persistence: A review of research literature on women's entrepreneurship in the information technology field. Entrepreneurial Report Series under the auspices of National Center for Women and Information Technology.

[110] Aidis, R., Welter, F., Smallbone, D., \& Isakova, N. (2007). Female entrepreneurship in transition economies: the case of Lithuania and Ukraine.Feminist Economics. 13(2), 157-183. DOI: 10.1080/13545700601184831.

[111] Wube, M.C. (2010). Factors Affecting the Performance of Women Entrepreneurs in Micro and Small Enterprises - A Case of Dessie Town. Thesis for Degree of Master of Arts in Technical and Vocational Education Management. Bahir Dar University.

[112] Pines, A.M., Lerner, M. and Schwartz, D. (2010). Gender differences in entrepreneurship equality, diversity and inclusion in times of global crisis. Equality, Diversity and Inclusion: An International Journal. 29 (2). pp(186-198). DOI 10.1108/02610151011024493. Emerald Publications.

[113] Diaze Gracia, M. and Welter, F. (2011). 'Gender Identities and Practices: Interpreting Women Entrepreneurs' Narratives'. International Small Business Journal. 31(4). (pp.384-404). DOI: 10.1177/0266242611422829. Sage Publications. 
[114] Alam, S.S., Jani, M.F.M., Omar, N.A. (2011). An Empirical Study of Success Factors of Women Entrepreneurs in Southern Region in Malaysia. International Journal of Economic and Finance. 3(2). (pp. 166-175). doi:10.5539/ijef.v3n2p166.

[115] Kariv, D. (2011). Entrepreneurship - An International Introduction. (1st ed.). Oxon, UK: Routledge.

[116] Zwan, P., Verheul, I. and Thurik, A.R. (2012). The Entrepreneurial Ladder, Gender and Regional Development. Small Business Economics. 39 (3). (pp.627-643). DOI: 10.1007/s11187-011-9334-7.

[117] OECD Council Report (2012). Gender Equality in Education, Employment and Entrepreneurship. Paris: Final Report to the MCM 2012 Meeting of the OECD Council at Ministerial Level. 23-24 May 2012

[118] Acs, Z.J. and Szerb, L. (2012). Global Entrepreneurship \& Development Index 2012. Cheltenham, UK: Edward Elgar.

[119] Dawson, C. Henley, A. (2012).'Push" versus 'Pull” Entrepreneurship: An Ambiguous Distinction?. International Journal of Entrepreneurial Behavior \& Research. 18 (6). (pp.697 - 719). Emerald Group.

[120] Aldas-Manzano, J., Martinez-Fuentes, C. and Pardo-del-Val, M. (2012). Women Entrepreneurship and Performance. Galindo, M. and Ribeiro, D. (Eds). Women's Entrepreneurship and Economics - New Perspectives, Practices and Policies. (pp.89-108). NY, USA: Springer.

[121] Rodriguez, F.R., Gonzalez-Sanchez, V.M. and Rios Sastre, S. (2012). The Profile of the European Entrepreneur: Economics and Finance, a Gender Analysis. Galindo, M. and Ribeiro, D. (Eds). Women's Entrepreneurship and Economics New Perspectives, Practices and Policies. (pp.143-165). NY, USA: Springer.

[122] Kamberidou, I. (2013). Women Entrepreneurs: We Cannot have Change Unless We Have Men in the Room. Journal of Innovation and Entrepreneurship, A Springer Open Journal. 2(6).

[123] Sarfaraz, L., Faghih, N. and Majd, A.A. (2014). The relationship between women entrepreneurship and gender equality. Journal of Global Entrepreneurship Research. 2(6). DOI:10.1186/2251-7316-2-6.

[124] Goyal, P., and Yadav, V. (2014). To be or not to be a Woman Entrepreneur in a Developing Country? Psychosociological Issues in Human Resource Management. 2 (2). (pp. 68-78). 
[125] Kauffman (2015). Challenges facing New Entrepreneurs in 2014. The Kauffman Foundation and LegalZoom Report.

[126] Das, M. (2000-01). Women Entrepreneurs from India: Problems, Motivations and Success Factors. Journal of Small Business \& Entrepreneurship. 15(4).

[127] Kollan, B., \& Parikh, I. J. (2005). A Reflection of the Indian Women in Entrepreneurial World. Pg. 12. Working Paper (Research and Publication, IIM-A, India) W.P. No. 2005-08-07, August 2005.

[128] Sarvamangala, R. (2006). Institutional support system and development of women entrepreneurship in Karnataka a special focus on Bangalore District. $\mathrm{PhD}$ Thesis. Kuvempu University. Shodhganga Repository.

[129] Govindappa, R. (2006). A Study of Women Entrepreneurship in Mumbai. PhD Thesis. SNDT Womens University. Shodhganga Repository.

[130] Rajani, N. (2008). Management Training Needs of Women Entrepreneurs. Anthropologist. 10(4). (pp. 277-281).

[131] Williams, and Gurtoo, (2011). Evaluating Women Entrepreneurs in the Informal Sector: Some Evidence from India. Journal of Developmental Entrepreneurship. 16(03). (pp. 351-369).

[132] Dwivedi, A.K. and Dwivedi, N. (2011). Women-Empowerment through Women Entrepreneurship (A Study of Faizabad Zone of Uttar-Pradesh).

[133] Narendran, R. (2011). Are the female entrepreneurs of beauty salons in India, victims of bad publicity?. International Journal of Diversity in Organisations, Communities and Nations. 11 (1). (pp 47-56).

[134] Waghmare, A.B. (2012). Women Entrepreneurship. $1^{\text {st }}$ Ed. Himalaya Publishing House. Delhi:India

[135] Berland, P.S. (2012). Dell Women's Global Entrepreneurship Study: India Key Findings. A Dell Study.

[136] Ghani, E, Kerr, W. R \& O'Connell, S D.(2013). Political Reservations and Women's Entrepreneurship in India. Policy Research Working Paper; No. 6307. World Bank, Washington, DC. (C) World Bank. Retrieved from https:/openknowledge.worldbank.org/handle/10986/12190 License: CC BY 3.0 IGO.

[137] Kumar, S.M., Mohan, H.S.C., Vijaya, C. and Lokeshwari, N. (2013). The Role of Women Entrepreneurship in Modern World. International Journal of Current Engineering and Technology. Special Issue (1). 
[138] IFC (2014). Micro, Small and Medium Enterprises- Improving Access to finance for Women-owned Businesses in India. IFC and World Bank Report.

[139] Veena, M. (2014). Managerial Performance of Women Entrepreneurs in Mysore District. PhD Thesis. University of Mysore. Shodhganga Repository.

[140] Patel, J.R.. (2005). Growth of Women Entrepreneurship in Baroda. PhD Thesis. Maharaja Sayajirao University. Shodhganga Repository.

[141] Roy, M. (14 ${ }^{\text {th }}$ May, 2005). Deepali has Designs on You. Business Standard.

[142] Roy, M. (23 ${ }^{\text {rd }}$ May, 2005). Knotting Her Way to Success. Business Standard.

[143] Samani, V. (2008). A Study of Women Entrepreneurs Engaged in Food Processing. $\mathrm{PhD}$ Thesis. Saurashtra University.

[144] Sinha, E. (2013). Women Entrepreneurship with Special Reference to Bardoli, Gujarat. ANVESHAN, IMR's Management Research Journal. 3(1). (pp - 30-35).

[145] Shastri, D and Rao, T.V. (2014). Women Entrepreneurs in Gujarat. Procedia Economics and Finance. 11(2014). (pp.745-752).

[146] Dave, V.D. (2014). Women Entrepreneurship development Special Reference to Ahmedabad City. PhD Thesis. Sardar Patel University. Shodhganga Repository.

[147] Balani, K. (28 ${ }^{\text {th }}$ August, 2014). They are Undeterred \& Strong. They are the Rural Women Entrepreneurs of Gujarat. [Blogpost].

[148] Junare, S.O. and Singh, R. (2016). Technological Understanding and Usage vis-àvis Knowledge of Government Scheme - A Study of Women Entrepreneurs of Selected Cities of Gujarat. Amity Journal of Entrepreneurship. 1(1). (pp. 71-85).

[149] Junare, S.O. and Singh, R. (2016). An Analysis of Technological Practice among Women Entrepreneurs of different Entrepreneurial Avenues in Selected Cities of Gujarat. Proceedings of $53^{\text {rd }}$ IRF International Conference, $24^{\text {th }}$ April, 2016, Pune, India.

[150] Bahmani, S., Sotos, F.E. \& Gracia, I.P. (2012). 'Women, Research and Entrepreneurship'. Galindo, M. \& Ribeiro (Eds). Women's Entrepreneurship and Economics. London, UK: Springer.

[151] ISRO and BISAG (2010). National Wetland Atlas - Guajarat.

[152] Laerd Statistics. Retrieved from https://statistics.laerd.com/spss-tutorials/testingfor-normality-using-spss-statistics.php 
[153] Yogendrarajah, R. (2011). Empowering Rural Women through Micro-credit on poverty alleviation, Self Employment and Health Nutrition under Post War Development. Gumbard Business Review. 6 (2). 1-17.

[154] World Bank, "Female Entrepreneurship: Program Guidelines and Case Studies", pp.1-65.

[155] Torero, M. \& von Braun, J. (2005). ICTs. Information and Communication Technologies for the Poor. The Potential of Telecommunications. IFPRI Issue Brief 40. Washington, DC: International Food Policy Research Institute.

[156] Caplan, S (2011, Aug 18). The Importance of Women Entrepreneurs. Forbes Article. 


\section{Appendix A}

\section{Interview Questions}

\section{SURVEY ANONYMITY CONFIDENTIALITY}

The researcher gives supreme importance to the confidentiality of survey data. Researcher assures you that the data collected will purely be used for academic purposes and will be kept confidential. No personal information will be supplied to third party unless you voluntarily offer personal or contact information in any of the comment fields. Additionally, your responses are combined with those of many others and summarized in a report.

Name:

Name \& Address of your Entrepreneurial Venture: -

Year of establishment: -

Type of Industry (Manufacturing/Service): -

If Manufacturing (Specify the name of product):-

If Service (Specify the type of service):-

\section{PERSONAL}

Q.1. What is your age? Tick any one.
A) Below 25
B) $25-35$
C) $36-45$
D) $46-55$
E) Above 55

Q.2. What is your educational background? Tick any one.
A) Below Matriculation
D) Graduate
B) Matriculation $\left(10^{\text {th }}\right)$
E) Post Graduate
C) Intermediate $\left(12^{\text {th }}\right)$ 
Q.3. What is your marital status?
A) Single
C) Divorced
B) Married
D) Widow

Q.4. How did you start your business?
A) I have started my business venture by my own
B) I have inherited it from my family
C) It is a business I have bought
D) I have inherited it from my in-laws.

Q.5. If you are/were married, what is/was your husband's occupation?
A) Business
D) Professional with own firm
B) Private or Government Service
E) Others
C) Freelance Professional

Q.6. What is your husband's education?
A) Illiterate
B) Below Matriculation
D) Intermediate
C) Matriculation
E) Graduate
F) Post Graduate

Q. 7. What is your father's education?
A) Illiterate
D) Intermediate
B) Below Matriculation
E) Graduate
C) Matriculation
F) Post Graduate

Q. 8. What is your mother's education?
A) Illiterate
D) Intermediate
B) Below Matriculation
E) Graduate
C) Matriculation
F) Post Graduate

Q. 9. What is your father's occupation?
A) Business
D) Professional with own firm
B) Private or Government Service
E) Others
C) Freelance Professional

Q. 10. What is your mother's occupation?
A) Business
D) Professional with own firm
B) Private or Government Service
E) Home Maker
C) Freelance Professional
F) Others 
Q.11. Is there anyone else in your family who has prior business experience?
A) Yes
B) $\mathrm{No}$

Q.12. Did you get any help from their experience to set up your business?
A) Yes
B) No

Q.13. What made you to become an entrepreneur?

* Multiple responses allowed
A) Family Business
B) Financial status of the family was weak
C) Always wanted to start business of my own
D) Due to lucrative Government Schemes
E) Due to boom in the existing industry
F) Due to strong business plan
G) Others (Please specify in the space provided)

\section{BUSINESS INFORMATION}

Q.14. What is the size of your business?
A) MICRO
(Manufacturing Sector - Does not exceed 25 lakh rupees) / (Service Sector - Does not exceed 10 lakh rupees)
B) SMALL

(Manufacturing Sector - More than 25 lakh rupees but does not exceed 5 crore rupees) / (Service Sector - More than 10 lakh rupees but does not exceed 2 crore rupees)

C) MEDIUM

(Manufacturing Sector - More than 5 crore rupees but does not exceed 10 crore rupees) / (Service Sector - More than two crore rupees but does not exceed five core rupees)

Q.15. How many such business's do you own?
A) 1
B) 2
C) 3
D) More than 3 
Q. 16. Is your business registered?
A) Yes
B) No

Q. 17. If yes, under which act is your business registered?

Q.18. How did you arrange the seed capital?

* Multiple responses allowed
A) Personal Savings
D) Local Creditors
B) Borrowing from family/relatives
E) Other Source (Please specify)
C) Bank Credit

Q. 19. How easy was it for you to establish your business?
A) Very easy
B) Moderate
C) Slightly difficult
D) Very difficult

Q. 20. Have you attended some Entrepreneurship Development Programmes?
A) Yes
B) No

Q. 21. If Yes, do you think Entrepreneurship Development Programmes are beneficial for the women to make them better entrepreneurs in Gujarat?
A) Yes
B) No

Q. 22. By how many percentages did your business revenue generation increased after attending Entrepreneurship Development Programme?
A) There was no change
B) $10-15 \%$
C) $15-20 \%$
D) $20-30 \%$
E) $30-40 \%$
F) More than $40 \%$ 
Q.23. What helped you the most to establish your business?

* Multiple responses allowed
A) Family
B) Relatives
C) Financial Institutions
D) Government Institution
E) Friends
F) Others (Please specify)

Q. 24. In your opinion what are the various enabling factor for women community to enter in entrepreneurship in Gujarat? List out the same.

\begin{tabular}{|l|l|l|}
\hline \multicolumn{1}{|c|}{ Factor } & Yes & No \\
\hline Education & & \\
\hline Prior Experience & & \\
\hline Family & & \\
\hline Society & & \\
\hline Finance & & \\
\hline Labor & & \\
\hline Government Schemes & & \\
\hline $\begin{array}{l}\text { Infrastructure (Buildings, Roadways, } \\
\text { Electricity, water etc) }\end{array}$ & & \\
\hline Location & & \\
\hline Being a women & & \\
\hline Children & & \\
\hline Intermediaries & & \\
\hline Training Programmes & & \\
\hline Competition & & \\
\hline Policy & & \\
\hline Laws & & \\
\hline Others (Please Specify) & & \\
\hline
\end{tabular}




\section{PROBLEMS}

\section{Q. 25. Financial Problems -}

\begin{tabular}{|l|l|l|}
\hline \multicolumn{1}{|c|}{ Problems } & Yes & No \\
\hline Limited Working Capital & & \\
\hline Lack of Collateral Security & & \\
\hline Delayed payments of bills & & \\
\hline Negative attitude of banks towards women & & \\
\hline Poor Knowledge of financial management & & \\
\hline $\begin{array}{l}\text { Ignorance about banking procedures \& } \\
\text { formalities }\end{array}$ & & \\
\hline Others & & \\
\hline
\end{tabular}

* Multiple responses allowed

\section{Q. 26. Personal Problems -}

\begin{tabular}{|l|l|l|}
\hline \multicolumn{1}{|c|}{ Problems } & Yes & No \\
\hline Lack of leisure time & & \\
\hline Lack of risk bearing capacity & & \\
\hline Avoidance of economic risk & & \\
\hline Lack of Self confidence & & \\
\hline Absence of need of achievement & & \\
\hline Lack of initiative & & \\
\hline Others (Please mention) & & \\
\hline
\end{tabular}

* Multiple responses allowed

\section{Q.27. Social Problems -}

\begin{tabular}{|l|l|l|}
\hline \multicolumn{1}{|c|}{ Problems } & Yes & No \\
\hline Dual role in home and business & & \\
\hline Lack of confidence in women's ability & & \\
\hline Male dominance & & \\
\hline Lack of social contacts & & \\
\hline Lack of appreciation in the family / society & & \\
\hline Others (Please mention) & & \\
\hline
\end{tabular}

* Multiple responses allowed 
Q.28. Raw Material Problems -

\begin{tabular}{|l|l|l|}
\hline \multicolumn{1}{|c|}{ Problems } & Yes & No \\
\hline Lack of continuous supply of raw materials & & \\
\hline Variations in raw materials prices & & \\
\hline Delay in procurement of raw materials & & \\
\hline Poor knowledge of materials management & & \\
\hline $\begin{array}{l}\text { Time consuming procedures of getting raw } \\
\text { materials }\end{array}$ & & \\
\hline Non availability of raw materials & & \\
\hline Others (Please mention) & & \\
\hline
\end{tabular}

* Multiple responses allowed

\section{Q.29. Marketing Problems -}

\begin{tabular}{|l|l|l|}
\hline \multicolumn{1}{|c|}{ Problems } & Yes & No \\
\hline Cut throat competition & & \\
\hline Delayed collection of bills & & \\
\hline Inadequate advertising and publicity & & \\
\hline Lack of sufficient stock of products & & \\
\hline Poor knowledge of marketing management & & \\
\hline Lack of travelling capacity & & \\
\hline Others (Please mention) & & \\
\hline
\end{tabular}

* Multiple responses allowed

\section{Q.30. Labour related Problems -}

\begin{tabular}{|l|l|l|}
\hline \multicolumn{1}{|c|}{ Problems } & Yes & No \\
\hline Non-availability of skilled employees & & \\
\hline $\begin{array}{l}\text { Skilled employees leave their job after getting } \\
\text { experience }\end{array}$ & & \\
\hline Non co-operative attitude of employees & & \\
\hline $\begin{array}{l}\text { Non co-operative attitude towards women } \\
\text { owner/manager }\end{array}$ & & \\
\hline Others (Please mention) & & \\
\hline
\end{tabular}

* Multiple responses allowed 
Q.31. Managerial Problems -

\begin{tabular}{|l|l|l|}
\hline \multicolumn{1}{|c|}{ Problems } & Yes & No \\
\hline Lack of proper planning & & \\
\hline Lack of control & & \\
\hline Poor knowledge of business management & & \\
\hline Lack of decision making skill & & \\
\hline Lack of Communication skill & & \\
\hline Lack of motivation to employees & & \\
\hline Others (Please mention) & & \\
\hline
\end{tabular}

* Multiple responses allowed

\section{Q. 32. Infrastructural Problems -}

\begin{tabular}{|l|l|l|}
\hline \multicolumn{1}{|c|}{ Problems } & Yes & No \\
\hline Inadequate space of work & & \\
\hline Inadequate power supply & & \\
\hline Non-availability of land / plot / Shed & & \\
\hline Inadequate transportation facilities & & \\
\hline Inadequate transportation facilities & & \\
\hline Inadequate water supply & & \\
\hline Others (Please mention) & & \\
\hline
\end{tabular}

* Multiple responses allowed

\section{Q.33. Technological Problems -}

\begin{tabular}{|l|l|l|}
\hline \multicolumn{1}{|c|}{ Problems } & Yes & No \\
\hline Lack of technological skill technological support for & & \\
\hline $\begin{array}{l}\text { Inadequate } \\
\text { machinery utilization }\end{array}$ & & \\
\hline Poor knowledge of modern technology & & \\
\hline High cost of technological acquisition & & \\
\hline Don't use technology & & \\
\hline Others (Please mention) & & \\
\hline
\end{tabular}

* Multiple responses allowed 
Q.34. Governmental Support Problems -

\begin{tabular}{|l|l|l|}
\hline \multicolumn{1}{|c|}{ Problems } & Yes & No \\
\hline $\begin{array}{l}\text { Corruption in sanction of subsidy, incentive } \\
\text { and loan }\end{array}$ & & \\
\hline Non co-operative attitude of govt. employees & & \\
\hline Poor knowledge government support schemes & & \\
\hline Discrimination with women entrepreneurs & & \\
\hline $\begin{array}{l}\text { Lack of co-ordination among different govt. } \\
\text { Departments }\end{array}$ & & \\
\hline Others (Please mention) & & \\
\hline
\end{tabular}

* Multiple responses allowed

\section{PROSPECTS}

Q.35.Which of the Social Environmental factors that have increased the prospects of Women Entrepreneurship?

\begin{tabular}{|l|l|l|}
\hline \multicolumn{1}{|c|}{ Social Environmental Factors } & Yes & No \\
\hline Increasing spread of education among women & & \\
\hline Increasing social recognition to women & & \\
\hline $\begin{array}{l}\text { Increasing awareness of women about economic } \\
\text { independence }\end{array}$ & & \\
\hline Peer effect & & \\
\hline $\begin{array}{l}\text { Increasing number of successful women in the } \\
\text { society }\end{array}$ & & \\
\hline Increasing automation of household work of women & & \\
\hline Increasing equality status of women & & \\
\hline
\end{tabular}

* Multiple responses allowed

Q.36. In which type of business activity does women entrepreneur has growth in Gujarat?

* Multiple responses allowed
a) Services
b) Trading
c) Manufacturing 
Q. 37. Which business activity is having growth prospect in Gujarat for women entrepreneurs?
a. Catering
h. IT services
b. Pre-school
i. Printing
c. Readymade garments
j. Retail Stores
d. Beauty Parlor
k. Image Building Institution
e. Grocery Retail Outlet
l.
Handicraft
Based
f. Event Management manufacturing unit
g. Farsaan Making
l. Others (Please Specify)

Q. 38. Can you suggest some measures to further improve the status of Women Entrepreneurs in the State of Gujarat?

Q.39. If you know few women entrepreneurs who run a business in any industry, kindly give their contact number and email id. 


\section{Appendix B}

\section{અંતિમ અભ્યાસ માટે પ્રક્ષૌત્તરી}

\section{સરવેઅનામિત્વગોપનીયતા}

સંશોધકમોજણી માહિતીનીગુપ્તતાનેસર્વોચ્યમહત્વઆપે છે.સંશો ધકએકત્રિત

માહિતીનોકેવળશૈક્ષણિકહેતુઓ માટે જ ઉપયોગકરવામાં આવશે અનેગુપ્ત રાખવામાં આવશે

તેની તમનેખાતરી આપે છે.તમે સ્વેચ્છાએટિપ્પણીક્ષેત્રોમાં કોઈપણવ્યક્તિગતઅથવા

સંપર્કમાહિતી પૂરી પાડો નહી ત્યાં સુધી ત્રાહિત પક્ષકારનેકોઈપણવ્યક્તિગત માહિતી પૂરી

પાડ વામાં આવશે નહીં વધુમાં, તમારાજવાબોઘણા લોકોસાથે જોડ વામાં આવે છેઅનેઅહેવાલમાં

સંક્ષિપ્ત કરવામાં આવે છે.

નામ: -

નામ અનેતમારાઔદ્યોગિક સાહસનું સરનામું:-

સ્થાખ્નાનું વર્ષ:-: -

ઉધોગ નો પ્રકાર (ઉત્પાદન/સેવા) :-

જો ઉત્પાદન હોય તો (ઉત્પાદનના નામનો ઉલ્લેખ કરો) :-

જો સેવા (તો કઇ પ્રકારની સેવા ):-

\section{व્યક્તિગત :-}

પ. 1 .તમારી ઉમર કેટલી છે ? કોઈપણ એક પર ટીક કરી
A. 25 થી ઓછી
D. $46-55$
B. $25-35$
E 55 थी उપર
C. $36-45$

પ્ર 2 .તમારી શૈક્ષણિક પ્રુષ્ઠભુમિ શું છે ? કોઈપણ એક પર ટીક કરી:
A. 10 મા ધોરણથી ઓછી
D. ગ્રેજ્યુએટ
B. 10 मु
E પોસ્ટ ગ્રેજ્યુએટ
C. 12 મु 
પ્ર 3 તમારી વૈવાહિક સ્થિતિ શું છે ?
A. એકલા
C. છુટા છેડા
B. પરણીત
D. विधवा

પ્ર 4. તમે તમારો વ્યવસાય શરૂ કેવી રીત કર્યો?
A.મેં જાતે જ મારો વ્યવસાય ચાલુ કર્યો.
B. મેં મારા પરિવાર પાસેથી વારસામાં મળ્યું છે.
C. આ વ્યવસાય મેં ખરીદ્યું છે.
D. મને મારા સસરા પાસેથી વારસામાં મળ્યું છે.

પ્ર 5. જો તમે વૈવાહિક છો/હતા, તો તમારા પતિ નું વ્યવસાય શું છે/હતો?
A. घંધો
D. વ્યવસાયિક પોતાના ધંધા સાથે
B. ખાનગી કे સરકારી નોકરી
E. जीજો કોઇ.
C. ફ્રીલાન્સિંગ પ્રોફેશનલ/ વ્યવસાયિક

પ 6. તમારા પતિ નું શિક્ષણ કેટલુ છે?
A. अशिक्षित
D. 12 मु
B. 10 માં ધોરણ थी ઓછું
E. ગ્રેજ્યએટ
C.10 मु
F. પોસ્ટ - ગ્રિજ્યુએટ

પ 7. તમારા પપ્પા નું શિક્ષણ કેટલુ છે?
A. अशिक्षित
D. 12 मु
B. 10 માં ધોરણ થી ઓધું
E. ગ્રેજ્યએટ
C.10 मु
F. પોસ્ટ - ગ્રેજ્યુએટ

પ્ર 8. તમારા મમ્મી નું શિક્ષણ કેટલુ છે?
A. अशिक्षित
D. 12 મु
B. 10 માં ધોરણ થી ઓધું
E. ગ્રેજ્યએટ
C. 10 मु
F. પોસ્ટ - ગ્રિજ્યુએટ 
પ્ર 9. તમારા પખ્પા નો વ્યવસાય શું છે?
A. घંધો
D. વ્યવસાયિક પોતાના ધંધા સાથે
B. ખાનગી કે સરકારી સેવા
E. બીજો કોઇ.
C. ફ્રીલાન્સિંગ પ્રોફેશનલ/ વ્યવસાયિક

પ્ર 10. તમારા મમ્મી નો વ્યવસાય શું છે?
A. घંધો
E. गૃહિણી
B. ખાનગી કે સરકારી સેવા
F. બીજો કોઇ.)આપેલ જગ્યામાં સ્પષ્ટ
C. ફ્રીલાન્સિંગ પ્રોફેશનલ/ વ્યવસાયિક
કરો)
D. વ્યવસાયિક પોતાના ધંધા સાથે

પ્ર 11. શુ તમારા પરિવાર માં બીજી કોઇ વ્યક્તિ ને વ્યવસાય ની અનુભવ પેહલા રહ્યો $छ ?$ ?
A. હા
B. ना

પ્ર 12. તમારો વ્યવસાય સ્થાપિત કરવા માટે તેમના અનુભવમાંથી તમે કોઈ મદદ มળવી?
A. હા
B. ना

પ્ર13. તમે ઉધૉગસાહસિક કેવી રીતે બન્યા?

(બહુવિધ પ્રતિભાવો માન્ય છે)
A. પારિવારિક વ્યવસાય
E. હાલના ઉદ્ધૉગના તજી ના કારણ.
B. પરિવાર ની આર્થિક સ્થિતિ ની
F. મજબુત બિઝનેસ ની યોજના ના કમજોરી કરણ.
C. હંમેશા મારો પોતાનો વ્યવસાય શરુ
G. બીજી કોઇ.(આપેલ જગ્યામાં સ્પષ્ટ કરવો હતો. કરી)
D. લાભદાયી સરકારી યોજનાઓ ના કારણે. 


\section{વ્યવસાયની માહિતિ}

પ્ર 14. તમારા ધંધાની સાઈઝ શું છે?

A. લધु ઉદ્યોગ

જો પ્લાન્ટ અને મશીનરીમાં રોકાણ નીચે જણાવ્યા મુજબ હોય

(ઉત્પાદન ક્ષેત્ર- રપ લાખથી વઘે નહીં અને / બિન ઉત્પાદન ક્ષેત્ર- ૧૦ લાખ થી વઘે નહીં)

B. નાના ઉદ્યોગ

જો પ્લાન્ટ અને મશીનરીમાં રોકાણ નીચે જણાવ્યા મુજબ હોય

(ઉત્પાદન ક્ષેત્ર- રપ લાખ થી વધુ પરંતુ પ કરોડ થી વધારે નહીં / બિન

ઉત્પાદક ક્ષેત્ર - ૧૦ લાખ થી વધુ પરંતુ ર કરોડ થી વઘે નહીં)

C. મધ્યમ કદના ઉદ્યોગ

(ઉત્પાદન ક્ષેત્ર- ૫ કરોડ થી વધુ પરંતુ ૧૦ કરોડ થી વઘે નહીં

બિન ઉત્પાદક ક્ષેત્ર -ર કરોડ થી વધુ પરંતુ પ કરોડ થી વઘે નહીં)

પ્ર 15. તેમે આવા કેટલા વ્યવસાયો ધરાવો છી?
A. $q$
C. 3
B. ₹
D. 3 થી વધારે

પ. 16 શું તમારો વ્યવસાય નોંધાયેલો (રજીસ્ટર્ડ) છે?
A. §l
B. नll

પ્ર.17 જો હા, તો કયા કાયદા (એક્ટ) હેઠળ તમારો વ્યવસાય નોંધાયેલ (રજીસ્ટર્ડ) છે?

પ્ર.18. તમે કેવી રીતે મૂડી સગવડ કરી?

(બહિવિધ પ્રિિભાવો માન્ય છે)

A. વ્યક્તિગત બચતમાંથી

C. બેંક ધિરાણ

B. કુંુંબ પાસે થી/ સગા- સંબંધીઓની

D. સ્થાનિક ઘિરાણ

પાસેથી ઉછીનાં નાણાં લી છે.

E. બીજી કોઇ પધ્ધતિ થી (અન્ય) 
પ્ર. 19. તમારા પોતાના ધંધાની શરૂઆત કરવી એ તમારા માટે કેટલું સરળ હતું?
А. ઘણું સરળ હતું
C. थोડું અઘરૂ
B. મધ્યમ હતું
D. घણું અઘરૂ હતું

પ્ર. 20.શું તમેકદી ઉદ્યોગસાહસ વિકાસ કાર્યક્રમમાં કોઈ તાલીમ મેળવેલી છે.?
A. §l
B. ना

પ્ર.21 શું તમે માનો છો કે ગુજરાતમાં સ્ત્રિઓને વધુ સારા ઉધોગસાહસિક બનાવવા માટે ઉદ્યોગસાહસ વિકાસ કાર્યક્રમ લાભદાયી છે?
A. §l
B. ना

પ્ર.22 તાલીમ મેળવ્યા પછી તમારા ધંધાની આવક કેટલા ટકા વધી?
A. કાર્યક્રમમાં તાલીમ મેળવ્યા પછી
D. १५-२० \% સફળતા પૂર્વક વ્યવસાય શરૂ કર્યો
E. २०-३० \%
B.કોઈ બદલાવ નથી
F. $30-80 \%$
C. $90-94 \%$
G. ૪૦ \% थी વધારે

પ્ર.23. તમારા ધંધાની સ્થાન્ના કરવામાં તમને સૌથી વધુ મદદ કોણે કરી?

(બહિવ્ધ પ્રતિભાવો માન્ય છે)
A. કુંટુબ
E. મિત્રૉ
B. સગા-સંબંધી
F. अन्य
C. નાણાંકીય સંસ્થા
D. સરકારી સંસ્થા 
પ્ર.24.તમારા મંતવ્ય મુજબ ગુજરાતમાં ઉધોગસાહસમાં દાખલ થવા સ્ત્રી સમુદાય માટે વિવિધ સામાર્થ્ય પરિબળો કયા છે?

\begin{tabular}{|l|l|l|}
\hline પરિબળ & હા & ના \\
\hline શિક્ષણ & & \\
\hline પહેલા નો અનુભવ & & \\
\hline કુટુબ & & \\
\hline સમાજ & & \\
\hline મૂડી સ્ત્રીતો & & \\
\hline મજુર & & \\
\hline સરકારી યોજનાઓ & & \\
\hline માળખું (બીલ્ડીંગ, માર્ગો, વીજળી, પાણી વગેર) & & \\
\hline સ્થળ & & \\
\hline $\begin{array}{l}\text { બાળકો ધંધો ચલાવવા/સફળતાપૂર્વક કામગીરી કરવામા } \\
\text { સામશ્ય્ય પરિબળ તરીકે ઉપયોગી }\end{array}$ & & \\
\hline $\begin{array}{l}\text { મદ્યસ્થી (સ્ત્રી ઉદ્યીગસાહસિક પ્રત્યે સપ્લાયર્સ અને } \\
\text { ડીસ્ટ્રીબ્યુટસ્સનો વર્તાવ) }\end{array}$ & & \\
\hline તાલીમનાં કાર્યક્રમ & & \\
\hline હરીફાઈ & & \\
\hline સરકારી નિતિ & & \\
\hline કાયદા કાનુન & & \\
\hline અન્ય & & \\
\hline
\end{tabular}


સમસ્યાઓ

તમારા મતે સ્ત્રી ઉદ્યોગ સાહસિકો દ્વારા સામનો કરવાનો થતો હોય તેવી સમસ્યાઓ અંગેના દરેક પ્રશ્નના વિકલ્પો પર 'હા' ટીક કરી.

પ્ર.25 નાણાંકીય સમસ્યાઓ-

\begin{tabular}{|c|c|c|}
\hline $\begin{array}{l}\text { સમસ્યાઓ } \\
\text { • મર્યાદીત રોકાયેલી મુડી. } \\
\text { • સહાયક જામીનગીરીની અછત } \\
\text { • ઘિરાણ આપનારન બીલોની વિલંબિત } \\
\text { ચૂકવણી } \\
\text { • બેંક નુ સ્ત્રીઓ પ્રત્ય નકારાત્મક વલણ/વર્તન } \\
\text { • નાણાકીય સંચાલનનુ ઓછી જાણકારી } \\
\text { • બેંકની કાર્યવાહી અને ઔપચારિકતાઓથી } \\
\text { અજાણ } \\
\text { • અન્ય }\end{array}$ & $\underline{s t}$ & नl \\
\hline
\end{tabular}

પ્ર. 26 વ્યક્તિગત સમસ્યાઓ

\begin{tabular}{|c|c|c|}
\hline સમસ્યાઓ & sl & ના \\
\hline 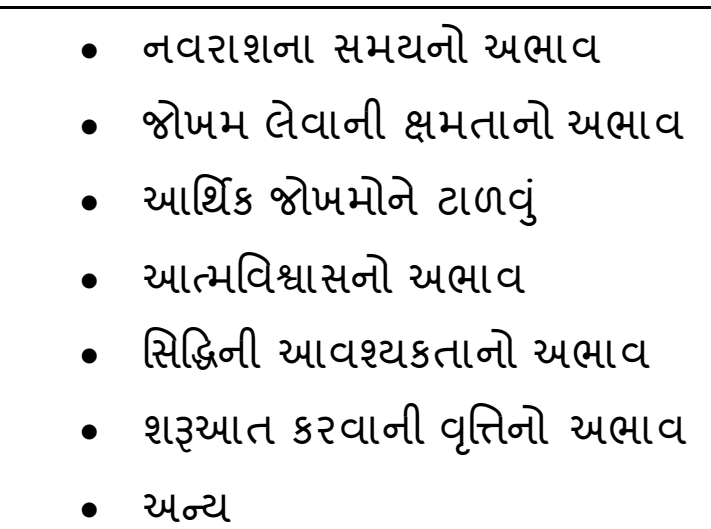 & & \\
\hline
\end{tabular}

પ્ર. 27 સામાજિક સમસ્યાઓ-

\begin{tabular}{|l|l|l|}
\hline સમસ્યાઓ & હા & ના \\
\hline • ધર અન ધંધોમાં બેવડી ભૂમિકા & & \\
• મહિલાઓની ક્ષમતા પર સમાજના વિશ્વાસની & & \\
અભાવ & & \\
• પુરુષોના અધિપત્યના કારણે સમસ્યા સજ્કાય & & \\
\hline
\end{tabular}


$\xi$

- સામાજીક સંપર્કોના અભાવના કારણે સમસ્યા

- કુટુંબ અને સમાજમાં પ્રશંસાનો અભાવના કારણે સમસ્યા

- અન્ય (વિગતવાર ઉલ્લેખ કરવો)

પ્ર.28 કાચામાલની સમસ્યાઓ-

\begin{tabular}{|l|l|l|}
\hline સમસ્યાઓ & હા & ના \\
\hline • કાચામાલના સતત પુરવઠાનો અભાવ & & \\
• કાચામાલના ભાવોમા વિવિધ્ધાના કારણ સમસ્યા & & \\
- કાચામાલની પ્રાપ્તિમાં વિલંબ & & \\
- સામગી સંચાલનમાં જ્ઞાનનો અભાવ & \\
- કાચો માલ મેળવવામાં વધુ સમય લાગે છે & \\
- કાચામાલની બિન ઉપલબ્ધતા & \\
• અન્ય (વિગતવાર ઉલ્લેખ કરવો) & \\
\hline
\end{tabular}

પ્ર. 29 માર્કેટીંગની સમસ્યાઓ-

\begin{tabular}{|l|l|l|}
\hline સમસ્યાઓ & હા & ના \\
\hline • તીવ્ર હરીફાઈ & & \\
• બિલની વસૂલાતમાં વિલંબ & & \\
• અયોગ્ય જાહેરાત અને પ્રચાર & \\
• ઉત્પાદનમાં પુરતા સ્ટોકનો અભાવ & \\
• માર્કેટીંગનાં મેનેજમેન્ટની ઓછી જાણકારી & \\
• અવર જવર માટે ક્ષમતાનો અભાવ & \\
• અન્ય (વિગતવાર ઉલ્લેખ કરવો) & & \\
\hline
\end{tabular}


પ્ર. 30 મજુરને લગતી સમસ્યાઓ:-

\begin{tabular}{|l|l|l|}
\hline સમસ્યાઓ & હા & ના \\
\hline • ફૂશળ (આવડતવાળા) કામદારોની બિન ઉપલબ્ધતા & & \\
• અનુભવ મળ્યા પછી આવડતવાળા મજુરી નોકરી & & \\
છોડી દે છે. & & \\
• મજુરનુ બિન-સહકારભયું વલણ & \\
• સ્ત્રી મેનજર/મેનજર તરફ બિન-સહકારભયું વલણ & & \\
• અન્ય (વિગતવાર ઉલ્લેખ કરવો) & & \\
\hline
\end{tabular}

પ્ર. 31 સંચાલનની સમસ્યાઓ

\begin{tabular}{|c|c|c|}
\hline સમસ્યાઓ & હા & ના \\
\hline 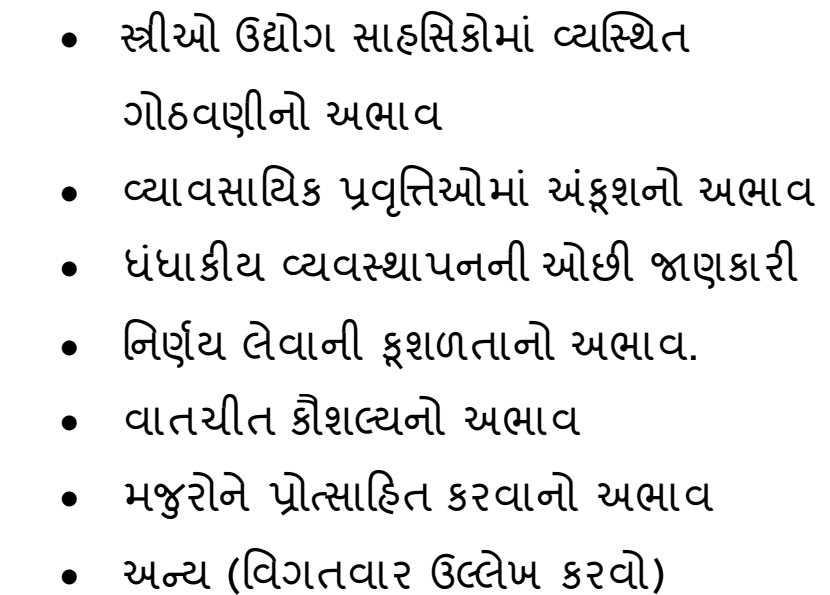 & & \\
\hline
\end{tabular}


પ્ર. 32 જરૂરીયાતોની (માળખાકીય) સમસ્યાઓ

\begin{tabular}{|l|l|l|}
\hline સમસ્યાઓ & હા & ના \\
\hline • કામ કરવાની અપૂરતી જગ્યા & & \\
• અપૂરતી વિજળીનો પુરવઠો & & \\
• જમીનની બિન ઉપલબ્ધતા & & \\
- અપૂરતી પરિવહન સુવિધાઓ & & \\
• અપૂરતો પાણીનો પુરવઠો . & & \\
• અન્ય (વિગતવાર ઉલ્લેખ કરવો) & & \\
\hline
\end{tabular}

પ્ર. 33. ટેક્નોલોજીની સમસ્યાઓ-

\begin{tabular}{|l|l|l|}
\hline સમસ્યાઓ & હા & ના \\
\hline • ટેક્નોલોજીકલ આવડતની અભાવ. & & \\
• મશીન ચલાવવા માટે અપૂરતો ટેક્નોલોજીકલ આધાર & & \\
• આધુનિક ટેકનોલોજીની ઓછી જાણકારી & & \\
- ટેક્નોલોજી સંપાદનની વધારે કિમંત & & \\
• ટેક્નોલોજી નો ઉપયોગ કરવો નહી. & & \\
• અન્ય (વિગતવાર ઉલ્લેખ કરવો) & & \\
\hline
\end{tabular}

પ્ર. 34. સરકારી સપોર્ટની સમસ્યાઓ-

\begin{tabular}{|l|l|l|}
\hline સમસ્યાઓ & હા & ના \\
\hline • લોન, પ્રોત્સાહન, અને સબસીડીની મંજુરીમાં ભષ્ટાચાર & & \\
• સરકારી કર્મચારીઓનુ બિન સહ્કારી વ્યવહાર & & \\
• સરકારી યોજનાઓનુ ઓછુ જ્ઞાન & & \\
• સ્ત્રી ઉધ્ધૉગસાહ્સિક સાથે ભેહભાવ & & \\
• અલગ અલગ સરકારી ખાતાઓમા સંકલનનો અભાવ & & \\
• અન્ય (વિગતવાર ઉલ્લેખ કરવો) & & \\
\hline
\end{tabular}


ભાવિઆશા, ઉમેદ

પ્ર. 35. ગુજરાતમાં કયાસામાજિક પરિબળોએ સ્ત્રી ઉદ્ધૉગ સાહસિકોની દરજ્જો અને આશામાં વધારો કર્યો છે?

\begin{tabular}{|c|c|c|}
\hline સામાજિક પર્યાવરણનાં કારણો & હા & ના \\
\hline 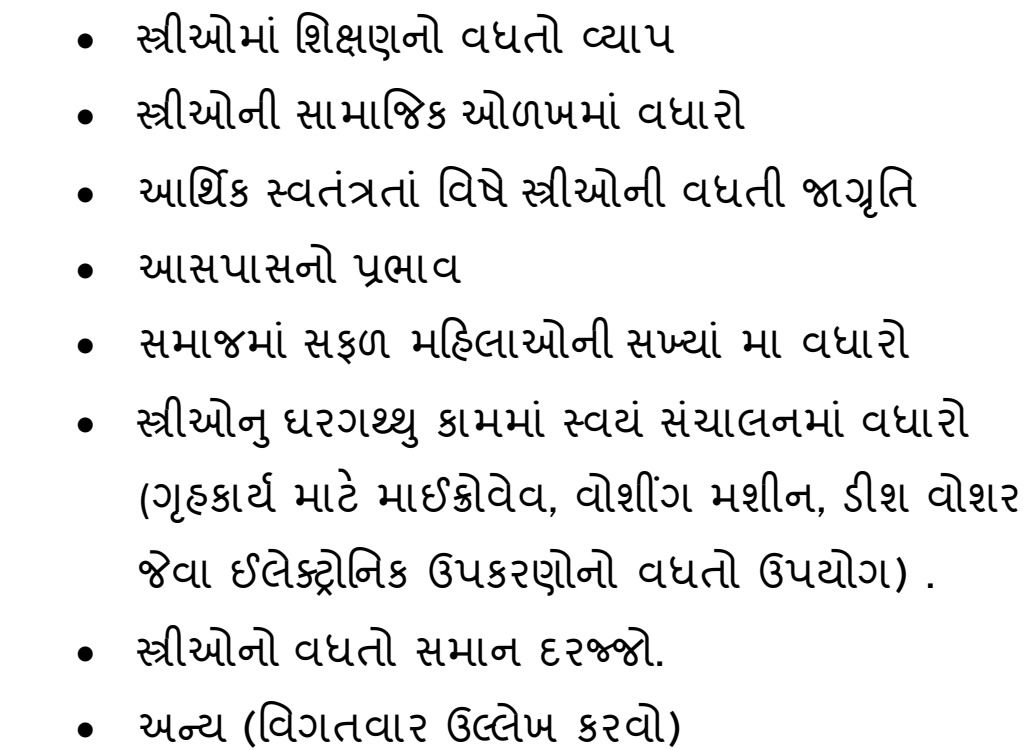 & & \\
\hline
\end{tabular}

પ્ર. 36. ગુજરાતમાં કયા પ્રકારના વ્યવસાય ઉદ્યોગમાં સ્ત્રી ઉધ્ધૉગસાહ્સિકોનો વિકાસ થયો छे ?

(બહુવિધ પ્રતિભાવો માન્ય છે)
A. સેવાક્ષેત્રની
C. ઉત્પાદન
B. વેપાર

પ્ર. 37. સ્ર્રી ઉધૉગસાહ્સિકી માટે ગુજરાત મા કઈ ધંધાકીય પ્રવૃત્તિમાં વિકાસની આશા છે?(બહિવિધ પ્રતિભાવો માન્ય છે) 

A. કેટરીંગ
H. આઈ. ટી. સેવાઓ
B. પ્રિ- સ્ફૂલ
।. પ્રિંન્ટીંગ
C. તૈયાર કપડાનો ધંધો
J. દુકાન
D. બ્યુટી પાર્લર
K. સંસ્થાઓનુ બાંધકામની કલ્પનાઓ
E. કરિયાણાનો દુકાન (ઈમેજ બિલ્ડીંગ ઈંસ્ટીટ્યુશન)
F. ઈवेન્ટ મેનેજમેન્ટ
L. ભરતગુંથણનુ ઉત્પાદન
G. ફરસાણ બનાવવું
M. અન્ય (વિગતવાર ઉલ્લેખ કરવો)

પ્ર. 38. શુ તમે ગુજરાત રાજ્યમાં સ્ત્રી ઉદ્ધૉગસાહસિકોના સ્થાનમાં વધુ સુધારી કરવા કેટલાંક પગલાઓ સૂચવી શકો છી?

પ્ર. ૩૯ કોઈપણ ઉદ્યોગમાં ધંધો ચલાવતી કેટલીક સ્ત્રી ઉદ્યોગ સાહસિકોન જો તમે જાણતા હોય તો કૃપ કરી તેઓના સંપઈ્ક નંબર અને ઈમેલ આઈડી આપો. 


\title{
Appendix C
}

\author{
Paper Publication
}

\section{Papers Published in International Referred Journal-}

[1] Junare, S.O \& Singh, R. (2016). Technological Understanding and Usage vis-à-vis Knowledge of Government Schemes - A Study of Women Entrepreneurs of Selected Cities of Gujarat. Amity Journal of Entrepreneurship. Vol-1, Issue- 1. (pp. 71-85). ISSN: 2455-9725 (Print) \& ISSN: 24456-1541 (Online)

\section{Papers Published in International Conference Proceedings-}

[1] Junare, S.O \& Singh, R. (2016). An Analysis of Technological Practice among Women Entrepreneurs of Different Entrepreneurial Avenues in Selected Cities of Gujarat. Conference Proceeding of $53^{\text {rd }}$ IRF International Conference on $24^{\text {th }}$ April, 2016 in Pune. ISBN- 978-93-886083-01-2

\section{Papers Published in National Conference Proceedings-}

[1] Singh, R. (2015). Women Entrepreneurship - Way to Economic Development through Corporate's Socially Responsible Act. National Seminar Proceeding Booklet of National Seminar organized by Unitedworld School of Law on $25^{\text {th }}-26^{\text {th }}$ July, 2015. ISBN - 978-93-80867-81-6.

[2] Singh, R. (2014). Gender Issues in Entrepreneurship - Impact of Socio-cultural aspect on Economic Growth of the State. Conference Proceeding e-Booklet (CD) of National Conference on Emerging Trends in Engineering, Technology and Management- 2014 in Indus University, Ahmedabad with ISBN No.978-81-923049-9-1. 